\begin{tabular}{|l|l|}
$\begin{array}{l}\text { 2. To: (Receiving orgenization) } \\
\text { Storage and Disposal }\end{array}$ & $\begin{array}{l}\text { 3. From: (origin } \\
\text { Disposal Enging }\end{array}$ \\
\hline $\begin{array}{l}\text { 5. Proj./Prog./Dept./0iv.: } \\
\text { Org. Code } 73510\end{array}$ & 6. coo. Engr.: \\
\hline
\end{tabular}

This document has been reviewed by WHC and DOE-RL staff and comments dispositioned. Final review and approval requested. Provide any significant comments to $R$. B. Calmus via cc:mail by the required response date.

11. Receiver Remerks:
8. Originator Remarks:

4. Related EDT Mo.:

N/A

7. Purchase Order Mo.:

N/A

9. Equip./Component No.: $N / A$

10. System/8ldg./Facility: $N / A$

12. Major Assm. Dug. Mo.: N/A

13. Permit/Permit Application No.: N/A

14. Required Response Date:

May 14, 1996

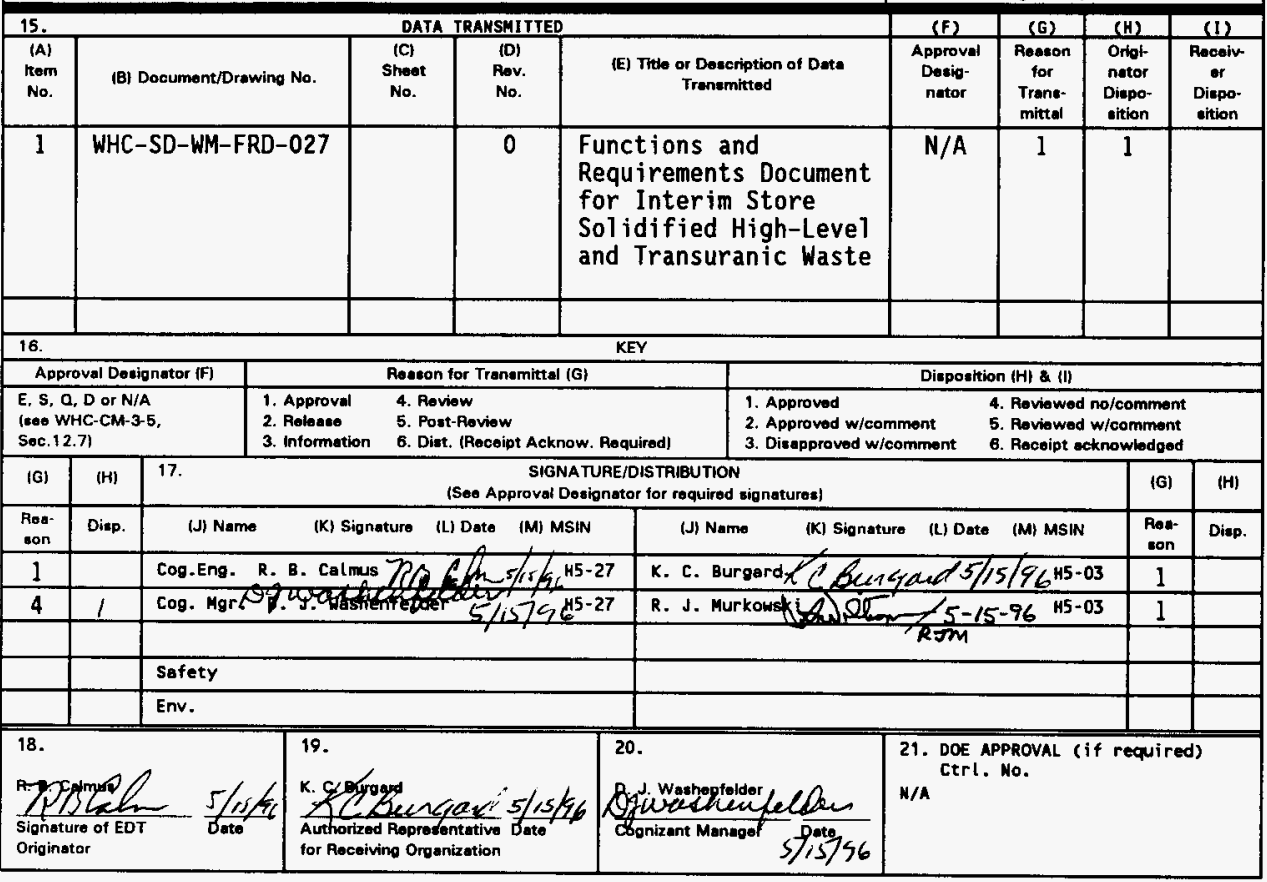




\title{
Functions and Requirements Document For Interim Store Solidified High-Level and Transuranic Waste
}

\author{
M. A. Smith-Fewell
}

Westinghouse Hanford Company, Richland, WA 99352

U.S. Department of Energy Contract DE-AC06-87RL10930
EDT/ECN: EDT No. 607724 UC: UC-2000, Environmental Management
Org Code: 73510 Charge Code: D4NB1
B\&R Code: EW3130010 Total Pages: $2 / 1$

Key Words: Functions, Requirements, High-Level Waste, Interim Store, Phase I, Privitization

Abstract: The functions, requirements, interfaces, and architectures contained within the Functions and Requirements (F\&R) Document are based on the information currently contained within the TWRS Functions and Requirements database. The database also documents the set of technically defensible functions and requirements associated with the solidified waste interim storage mission.

The F\&R Document provides a snapshot in time of the technical baseline for the project. The F\&R document is the product of functional analysis, requirements allocation and architectural structure definition. The technical baseline described in this document is traceable to the TWRS function 4.2.4.1, Interim Store Solidified Waste, and its related requirements, architecture, and interfaces. TRADEMARK OISCLAIMER. Reference herein to any specific comercial product, process, or service by
trade name, trademark, manufacturer, or otherwise, does not necessarily constitute or imply its
endorsement, recomendation, or favoring by the United states Goverment or any agency thereof or its contractors or subcontractors.

Printed in the United States of America. To obtain copies of this document, contact: WHC/BCS Document Control Services, P.O. BOX 1970, Mailstop H6-08, Richland WA 99352, Phone (509) 372-2420; Fax (509) 376-4989.
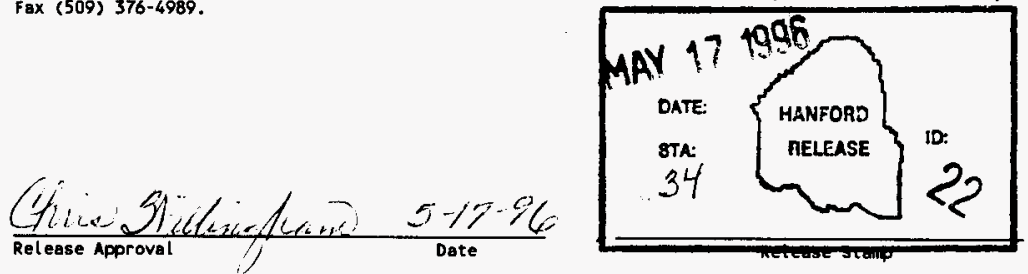

Approved for Public Release 
U. S. Department of Energy Richland Operations Office, Richland, Washington

by

Westinghouse Hanford Company

Richland, Washington 99352 
WHC-SD-WM-FRD-027 Rev. 0

This page intentionally left blank. 
WHC-SD-WM-FRD-027 Rev. 0

\section{EXECUTIVE SUMAARY}

This functions and requirements document (FRD) identifies and defines the functions, requirements, interfaces, and architectures associated with the interim storage of solidified high-level waste (HLW) and transuranic (TRU) waste. The functions, requirements, interfaces, and architectures contained within this document are based on the information contained within the Tank Waste Remediation System (TWRS) requirements database, which is the result of a TWRS program-level systems engineering analysis.

This FRD also incorporates relevant facets of the U.S. Department of Energy (DOE) planned privatization effort for Hanford Site tank waste treatment and immobilization services. This privatization effort is divided into two phases. The first phase, termed the "proof of concept" or Phase I, will establish and demonstrate the technical, commercial, and procurement viability of privatized Hanford Site tank waste treatment and immobilization. The second phase, termed Phase II, will treat and immobilize the remainder of the tank waste.

The solidified waste (products) from the privatization treatment and immobilization activities will require interim storage until the products can be shipped offsite for permanent disposal at a geologic repository, or delivered to an onsite treatment facility for further processing. Facilities, services, and equipment necessary for interim storage are to be provided by the Hanford Site Management and Integration (M\&I) Contractor or a subcontractor. Interim storage of the solidified waste begins with the M\&I Contractor's acceptance of the solidified waste at the privatization vendor's facility, and ends with the transfer of responsibility for the solidified 
waste to the DOE Office of Civilian Radioactive Waste Management or to an onsite processing facility.

The information provided in this document is traceable to the TWRS fourth-level Function 4.2.4.1, Interim Store Solidified HLW and TRU Waste, and its related requirements, architecture, and interfaces." The proposed fifth-level subfunctions of Function 4.2.4.1, defined in this document, are Interim Store Dispositioned Cs/Sr Capsules, Interim Store Phase I Solidified $H L W$, Interim Store Phase II Solidified HLW and TRU Waste, and Prepare Solidified $H L W$ and TRU for Shipping. This decomposition supports the privatization process. This document further decomposes the function Interim Store Phase I Solidified $H L W$ to the sixth level, and identifies inputs, outputs, and requirements for each function.

The information provided in this document will be used in developing the relevant sections of the technical requirements specification for Function 4.2.4, Dispose Waste, and the design requirements document for the Phase I Solidified HLW Interim Storage System. The TWRS requirements database will be updated to incorporate the information provided in this document.

"WHC, 1996, Tank Waste Remediation System Functions and Requirements, WHC-SD-WM-FRD-020, Rev. 0, Westinghouse Hanford Company, Richland, Washington. 


\section{CONTENTS}

1.0 INTRODUCTION ................... . . . . . . .

1.1 BACKGROUND ................... 1-...

1.2 SYSTEM PURPOSE AND SCOPE ............... . . . . . .

2.0 DOCUMENT OVERVIEW ....................... 2-1

2.1 MISSION AND SCOPE ................ 2- . . . .

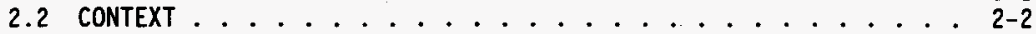

3.0 FUNCTIONS ......................... 3-1

3.1 FUNCTION HIERARCHY . . . . . . . . . . . . . . . . . 3-1

3.2 FUNCTION DESCRIPTION .......................

4.0 INTERFACES . . . . . . . . . . . . . . . . . 4-1

4.1 INTERFACE IDENTIFICATION ................ . . . . . .

4.2 INTERFACE DESCRIPTION . . . . . . . . . . . . . . 4-1

5.0 REQUIREMENTS ALLOCATION . . . . . . . . . . 5-1

5.1 REQUIREMENTS ALLOCATION TO FUNCTIONS $\ldots$

5.2 REQUIREMENTS ALLOCATED TO INPUTS AND OUTPUTS . . . . . . . 5-1

6.0 ARCHITECTURE . . . . . . . . . . . . . . . . . . . . 6-1

6.1 ARCHITECTURE IDENTIFICATION NUMBER: TO BE DETERMINED $\ldots . .6-1$

6.2 ARCHITECTURE TITLE: SOLIDIFIED HLW AND TRU WASTE INTERIM

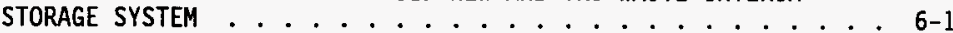

6.3 ARCHITECTURE DEFINITION (PHASE I AND PHASE II) $\ldots \ldots \ldots-1$

6.4 ALTERNATIVES CONSIDERED . . . . . . . . . . . . 6-1

6.5 RATIONALE FOR SELECTION . . . . . . . . .

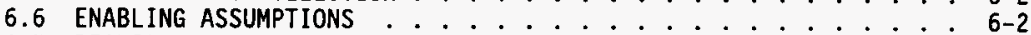

6.7 REQUIRED ANALYSES ................ . . . . . . .

6.8 REQUIREMENTS SATISFIED . . . . . . . . . . . $6-3$

7.0 REQUIREMENTS DEFINITION ..................... . . . .

8.0 REFERENCES ..................... 8-1 
WHC-SD-WM-FRD-027 Rev. 0

\section{LIST OF FIGURES}

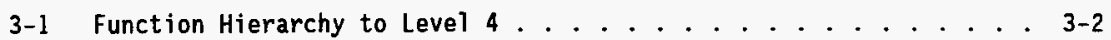

3-2 Decomposition of Function 4.2.4.1............... 3-3

\section{LIST OF TABLES}

3-1 Functions and Inputs/Outputs . . . . . . . . . . . . . . . . 3-4

4-1 Input and Output Descriptions ................ . 4-2

5-1 Requirements Allocated to Functions. . . . . . . . . . . . . . 5-2

5-2 Requirements Allocated to Inputs/Outputs. . . . . . . . . . . 5-15

7-1 Constraint Definitions . . . . . . . . . . . . . . . . 7-2

7-2 Performance Requirement Definitions . . . . . . . . . . . . 7-102

7-3 Proof-of-Concept Requirement Definitions. . . . . . . . . . 7-115 


\section{ACRONYMS}

$\begin{array}{ll}\text { ALARA } & \text { as low as reasonabiy achievable } \\ \text { ASIL } & \text { acceptance source impact level } \\ \text { BARCT } & \text { best available radionuclide control technology } \\ \text { CEDE } & \text { committed effective dose equivalent } \\ \text { CFR } & \text { Code of Federal Regulations } \\ \text { CS } & \text { cesium } \\ \text { DOE } & \text { U.S. Department of Energy } \\ \text { EEM } & \text { Environmental Emission Management } \\ \text { EO } & \text { Executive Order } \\ \text { EPA } & \text { U.S. Environmental Protection Agency } \\ \text { ETF } & \text { Effiuent Treatment Facility } \\ \text { F\&R } & \text { functions and requirements } \\ \text { FRD } & \text { functions and requirements document } \\ \text { HLW } & \text { high-level waste } \\ \text { ICSSC } & \text { Interagency Committee of Seismic Safety in Construction } \\ \text { IHLW } & \text { immobilized high-level waste } \\ \text { IRIS } & \text { Integrated Risk Information System } \\ \text { IS } & \text { interim store } \\ \text { ITRU } & \text { immobilized transuranic (waste) } \\ \text { LERF } & \text { Liquid Effluent Retention Facility } \\ \text { LDR } & \text { land disposal restriction } \\ \text { LLW } & \text { low-level waste } \\ \text { M\&I } & \text { Management and Integration } \\ \text { M\&O } & \text { Maintenance and Operation } \\ \text { MEI } & \text { maximally exposed individual } \\ \text { MTW } & \text { manage tank waste } \\ \text { NEHRP } & \text { National Earthquake Hazards Reduction Program } \\ \text { NOC } & \text { notice of construction } \\ \text { OCRWM } & \text { office of Civilian Radioactive Waste Management } \\ \text { OSHA } & \text { Occupational Safety and Health Administration } \\ \text { PCT } & \text { product consistency test } \\ \text { QA } & \text { quality assurance } \\ \text { QAPP } & \text { quality assurance project plan } \\ \text { QARD } & \text { quality requirements and description } \\ \text { RTR } & \text { real-time radiography } \\ \text { SGW } & \text { system-generated waste } \\ \text { SNM } & \text { special nuclear materials } \\ \text { Sr } & \text { strontium } \\ \text { TAP } & \text { toxic air pollutant } \\ \text { TCLP } & \text { toxicity characteristics leaching procedure } \\ \text { TEDF } & \text { Treated Effluent Disposal Facility } \\ \text { TRS } & \text { technical requirements specification } \\ \text { TRU } & \text { transuranic (waste) } \\ \text { TSD } & \text { treatment, storage, or disposal } \\ \text { TWRS } & \text { Tank Waste Remediation System } \\ \text { WA } & \text { Waste Acceptance } \\ \text { WAC } & \text { Washington Adminstrative Code } \\ \text { WIPP } & \text { Waste Isolation Pilot Plant } \\ & \\ & \end{array}$


WHC-SD-WM-FRD-027 Rev. 0

This page intentionally left blank. 


\section{FUNCTIONS AND REQUIRENENTS DOCUNENT FOR INTERIM STORE SOLIDIFIED HIGH-LEVEL WASTE AND TRANSURANIC WASTE}

\subsection{INTRODUCTION}

\subsection{BACKGROUND}

The mission of the Tank Waste Remediation System. (TWRS) is to store, treat and immobilize highly radioactive waste in an environmentally safe, sound, and cost-effective manner. The U.S. Department of Energy (DOE) established this program to manage the underground waste storage tanks at the Hanford Site. The TWRS program includes all activities related to management, retrieval, processing, and disposal of all existing wastes in the tanks and new wastes introduced to the tanks.

In July 1995, the DOE embarked upon a course to acquire Hanford Site tank waste treatment and immobilization services using privatized facilities. Privatization is defined as vendors, under contract with the DOE, using private funding to design, permit, construct, operate, decontaminate, and decommission their own equipment and facilities to treat tank waste (RL 1996). Privatization is divided into two phases. The first phase, termed the "proof of concept" or Phase I, will begin with award of contract in 1996, and operate through at least 2005, while treating approximately $6 \%$ to $13 \%$ of the tank waste. Phase I will establish and demonstrate the technical, commercial, and procurement capabilities necessary for the privatization of Hanford Site tank waste treatment and immobilization. Phase II, which begins with the award of a second contract, will treat and immobilize the remainder of the tank waste.

The privatization contractor(s) will manage the Hanford Site tank waste transferred to their custody; retrieve and transfer this waste for processing; immobilize the waste; and prepare the resultant solidified waste for return to the Management and Integration (M\&I) Contractor. The M\&I Contractor will receive sealed containers of solidified high-level waste (HLW) and transuranic (TRU) waste for interim storage until it can be shipped offsite for permanent disposal, or sent to a treatment facility for further processing. The specific forms of solidified HLW/TRU waste produced during Phase $I$ and requiring interim storage are solidified cesium (Cs) product separated from the low-level waste (LLW) fraction of the tank supernatant, and immobilized HLW. During Phase II, the products requiring interim storage are immobilized HLW and immobilized TRU waste. Dispositioned $C s$ and strontium (Sr) capsules may also require interim storage during Phase II pending a programmatic decision on whether to vitrify or overpack this material.

\subsection{SYSTEM PURPOSE AND SCOPE}

The purpose of the Solidified HLW and TRU Waste Interim Storage Systems is to provide the necessary facilities and equipment for interim storage of immobilized HLW, immobilized TRU waste, Cs product, and dispositioned Cs/Sr capsules. Interim storage of the solidified waste begins with acceptance of the waste from the production facility, and ends with the transfer of responsibility for the waste to the DOE Office of Civilian Radioactive Waste 
Management (DOE-OCRWM) for shipment to a permanent geologic repository, or (for the Cs -product only) to an onsite facility for further processing.

Additional information on the interfaces between the private vendors and the interim storage system is presented in DE-RP06-96RL13308, TWRS Privatization Request for Proposals (RL 1996).

The primary purpose of this document is to establish a consistent basis for development of the relevant sections of the technical requirements specification (TRS) for Function 4.2.4, Dispose Waste, and the design requirements document for the Phase I Solidified HLW Interim Storage System. The TWRS requirements database will be updated to incorporate the information provided in this document. 
WHC-SD-WM-FRD-027 Rev. 0

\subsection{DOCUMENT OVERVIEW}

\subsection{MISSION AND SCOPE}

The functions, requirements, interfaces, and architectures associated with the TWRS mission are contained within the TWRS Systems Engineering database. The database is the result of a TWRS program-level systems engineering analysis. The functions, requirements, interfaces, and architectures contained within this functions and requirements document (FRD) are based on the information currently contained within the TWRS requirements database. The database also documents the set of technically defensible functions and requirements (F\&R) associated with the solidified waste interim storage mission.

This document provides the basis for the Interim Store Solidified $H L W$ and TRU Waste portion of the TRS for Dispose Waste; and for the design requirements document (DRD) for the Phase I Solidified HLW Interim Storage system. The FRD consists of the following sections.

- Introduction - Provides the background and purpose of the Solidified HLW and TRU Waste Interim Storage System.

- Overview - Provides a brief description of the FRD and its relationship to the site Systems Engineering effort.

- Functions - Includes the hierarchy of the functions applicable to this activity, defines each function, and lists the inputs and outputs of each function.

- Interfaces - Defines the interfaces (inputs and outputs) between functions, and identifies their relationships to the functions.

- Requirements Allocation - Lists the constraints, performance requirements, and proof-of-concept requirements allocated to each function and each input/output associated with the interim storage of solidified HLW and TRU waste.

- Architecture - Identifies the architecture that was selected for the Solidified HLW and TRU Waste System after evaluating and deciding on a candidate, optimal architecture output from the functional analysis. The evaluation and decision process is supported by trade-off study reports, which are referenced in this section. The section also identifies the analysis needed for the next level of architecture selection, and lists the requirements satisfied by the selected architecture.

- Requirements Definition - Provides the text of the constraints, performance requirements, and proof-of-concept requirements associated with the functions, interfaces, and architecture.

- References - Lists the documents used in development of this FRD. 


\subsection{CONTEXT}

The information provided in this document is traceable to TWRS

Function 4.2.4.1, Interim Store Solidified $H L W$ and $T R U$ Waste, and its related requirements, architecture, and interfaces. Section 3.1 describes the function hierarchy. This FRD provides the functions, requirements, inputs, outputs, and architectures that resulted from the functional analysis, requirements allocation, and architectural structure definition.

Function 4.2.4.1 is decomposed to the fifth level to provide a basis for the Interim Store Solidified $H L W$ and TRU Waste portion of the Dispose Waste TRS. The proposed fifth-level function Interim store Phase $I$ Solidified $H \mathrm{LW}$ is decomposed to the sixth level, to provide a basis for the DRD for the Phase I Solidified HLW Interim Storage System. 


\subsection{FUNCTIONS}

\subsection{FUNCTION HIERARCHY}

Figure 3-1 shows the function hierarchy from Function $0, C l e a n$ Up Hanford, to Function 4.2.4.1, Interim Store Solidified HLW and TRU Waste. Shaded blocks indicate the traceability path of Function 4.2.4.1 to Function 0 . This information is consistent with the TWRS Systems Engineering database.

Figure 3-2 illustrates the decomposition of Function 4.2.4.1. Shaded blocks indicate functions that will be addressed in the Phase I Solidified HLW Interim Storage System DRD.

\subsection{FUNCTION DESCRIPTION}

Table 3-1 provides descriptions of Function 4.2.4.1, Interim Store Solidified $H L W$ and TRU Waste, and its subfunctions; and identifies the inputs and outputs associated with each function. 


\section{Figure 3-1. Function Hierarchy to Level 4.}

\begin{tabular}{|c|c|}
\hline $\begin{array}{l}\text { O } \\
\text { Cloen up Hanford }\end{array}$ & Manoge Progrem \\
\hline & $\begin{array}{l}2 \\
\text { Acquire Miesion } \\
\text { Esesential Cepabilitios }\end{array}$ \\
\hline & $\begin{array}{l}3 \\
\text { Obtain Public } \\
\text { Acceptance }\end{array}$ \\
\hline & $\begin{array}{l}4 \\
\text { Aomady Unealo And } \\
\text { Unicocoptable } \\
\text { Conditionse }\end{array}$ \\
\hline
\end{tabular}

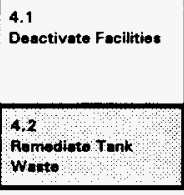

4.3

Romedy Solid Waste

4.4

Pomed y/Pestore

Sites, Facilities, 4

Groundwater

4.5

Menago Aqueous

Wastes

4.7

Store, Treat, and

Disposition

SNM/NM/NF

Matorials:

\begin{tabular}{|l|}
\hline $\begin{array}{l}4.2 .1 \\
\text { Manege Tenk Woste } \\
\text { (MTW) }\end{array}$ \\
\hline $\begin{array}{l}4.2 .2 \\
\text { Retrieve Tank Wasto }\end{array}$ \\
\hline 4.2 .3 \\
Procese Weste \\
4.2 .4 _ \\
\hline Dispoco Weste \\
\hline
\end{tabular}

4.2.4.1

Intentin store

Solfidilied HEW and

TRu Waste

\subsubsection{2 \\ Diepote ILLW \\ 4.2.4.3 \\ Close Operable \\ Units (Tanks)}

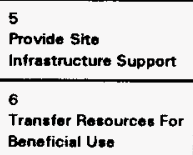

5

Provide Sito

astructure Support

Transfer Resources For Beneficial Use 
Figure 3-2. Decomposition of Function 4.2.4.1.

\subsubsection{1}

Interim store solidified

HLH and TRU Waste
4.2.4.1.1

Inter im Store

Dispositioned Cs/sr

Cepsules

\section{2 .4 .1 .2}

Interin store phase I

Solidified HLW
4.2.4.1.2,1

Aceept Phase 1 sal idif ied HLW

from Producer

6.2 .4 .1 .2 .2

Iransport Phase 1 solidified

HLI to Inter in storage

4.2.4.1.2.3

Isolate Phase I solidified HLW

$4.2,4,1.2,4$

Retr ieve Phase I solidified

HL W from storage

4.2.4.1.2.5

Del iver Phase 1 sol fdified HLW

for shipping or processing

$4.2,4.1 .2 .6$

support storage of Phese I

solidified HLW
4.2 .4 .1 .3

Interim Store Phase II

Sol idified HLH and TRU

Waste

$$
\text { 4.2.4.1.4 }
$$

Prepare Solidified HLW and

TRU for Shipping 
Table 3-1. Functions and Inputs/Outputs. (14 sheets)

Inputs :

Cesium Product for Storage

Dispositioned Cs/Sr Capsules for Storage

Dispositioned Cs/Sr Capsules

Shipping Mechanism

IHLW for Storage

Phase I IHLW for Storage

Phase II IHLW for Storage

IHLW Repository Shipping Mechanism

Infrastructure Support for IS

Solidified HLW and TRU

Infrastructure Support for IS

Dispositioned $\mathrm{CS} / \mathrm{Sr}$ Capsules

Infrastructure Support for IS Phase I Solidified HLW Phase II Solidified HLW

Infrastructure Support for Prepare Solidified HLW for Shipment

ITRU Repository Shipping Mechanism ITRU Waste for Storage

Raw Materials for IS Solidified HLW and TRU

Raw Materials for IS

Dispositioned Cs/Sr Capsules

Raw Materials for IS Phase I Solidified HLW

Raw Materials for IS Phase II Solidified HLW

Raw Materials for Prepare Solidified HLW for Shipment

\subsubsection{1}

Interim Store Solidified HLH and TRU Waste

Accept solidified high-level waste (HLW) [i.e., immobilized HLW (IHLW) and immobilized transuranic waste (ITRU) canisters from the $\mathrm{HLW}$ immobilization facility, cesium product containers from the pretreat supernatant facility, and dispositioned cesium/ strontium ( $C s / S r$ ) capsules from the $C s / S r$ capsule disposal preparation system]. Transport solidified $H L W$ to the appropriate interim storage facilities. Prepare and emplace solidified HLW in designated storage locations, monitor the storage locations for containment integrity, and eventually retrieve the solidified HLW from storage. Prepare the solidified $H L W$ for shipment and load it into casks for shipment to an offsite geologic repository for disposal, or deliver the solidified $H L W$ to an onsite treatment facility for further processing.
Outputs :

Cesium Product for Processing

Cesium Product Transport Mechanism

Dispositioned $\mathrm{Cs} / \mathrm{Sr}$ Capsules for

Shipment

Dispositioned Cs/Sr Capsules

Transport Mechanism

IHLW for Shipment

IS Solidified HLW and TRU Excess

Facilities

IS Dispositioned Cs/Sr Capsules Excess Facilities

IS Phase I Solidified HLW Excess Facilities

IS Phase II Solidified HLW and TRU Excess Facilities

Prepare Solidified HLW and TRU for Shipment Excess Facilities

IS Solidified HLW and TRU Garbage

IS Dispositioned Cs/Sr Capsules Garbage

IS Phase I Solidified HLW Garbage

IS Phase II Solidified HLW and TRU Garbage

Prepare Solidified HLW and TRU for Shipment Garbage

IS Solidified HLW and TRU Hazardous Waste

IS Dispositioned Cs/Sr Capsules Hazardous Waste

IS Phase I Solidified HLW Hazardous Waste

IS Phase II Solidified HLW and TRU Hazardous Waste

Prepare Solidified HLW and TRU for Shipment Hazardous Waste 
Table 3-1. Functions and Inputs/0utputs. (14 sheets)

Inputs (cont inued):

Solidified HLW and TRU Production Information

Dispositioned $\mathrm{Cs} / \mathrm{Sr}$ Capsules Production Information

Phase I IHLW Production Information

Cesium Product Production Information

Phase II Solidified HLW Production Information

\subsubsection{1}

Interim Store Solidified HLW and TRU Haste (continued)

Subfunctions:

Interim Store Dispositioned $\mathrm{Cs} / \mathrm{Sr}$ Capsules

Interim Store Phase I Solidified $\mathrm{HLW}$ Interim Store Phase II Solidified HLW and TRU Waste Prepare Solidified HLW and TRU for Shipment
Outputs (continued):

IS Solidified HLW and TRU Prepared Sol id Waste

IS Dispositioned Cs/Sr Capsules Prepared Solid Waste

IS Phase I Solidified HLW Prepared Solid Waste

IS Phase II Solidified HLW and TRU Prepared Solid Waste Prepare Solidified HLW and TRU for Shipment Prepared Solid Waste

IS Solidified HLW and TRU Treated Gaseous Effluents

IS Dispositioned Cs/Sr Capsules Treated Gaseous Effluents IS Phase I Solidified HLW Treated Gaseous Effluents IS Phase II Solidified HLW and TRU Treated Gaseous Effluents Prepare Solidified HLW and TRU for Shipment Treated Gaseous Effluents

IS Solidified HLW and TRU Treated Liquid Effluents

IS Dispositioned Cs/Sr Capsules Treated Liquid Effluents

IS Phase I Solidified HLW Treated Liquid Effluents IS Phase II Solidified HLW and TRU Treated Liquid Effluents Prepare Solidified HLW and TRU for Shipment Treated Liquid Effluents 
Table 3-1. Functions and Inputs/Outputs. (14 sheets)

\subsubsection{1}

Interin store Solidified HLW and TRU Waste

(cont inued)
Outputs (continued):

IS Solidified HLW and TRU

Untreated Liquid Effluents

IS Dispositioned Cs/Sr Capsules Untreated Liquid Effluents

IS Phase I Solidified HLW Untreated Liquid Effluents

IS Phase II Solidified HLW and TRU Untreated Liquid Effluents Prepare Solidified HLW and TRU for Shipment Untreated Liquid Effluents

ITRU for Shipment

Phase I IHLW Transport Mechanism

Phase II Solidified HLW and TRU

Transport Mechanism

Solidified HLW and TRU

Recertification Information

Solidified HLH and TRU Storage Information

Dispositioned Cs/Sr Capsules Storage Information

Phase I IHLW Storage Information Cesium Product Storage

Information

Phase II Solidified HLW Storage Information 
Table 3-1. Functions and Inputs/0utputs. (14 sheets)

Inputs :

Dispositioned Cs/Sr Capsules for Storage

Dispositioned Cs/Sr Capsules Production Information

Infrastructure Support for IS

Dispositioned Cs/Sr Capsules

Raw Materials for IS Dispositioned Cs/Sr Capsules

\subsubsection{1}

Interim Store Dispositioned Cs/Sr Capsules

Accept sealed onsite transport casks loaded with dispositioned cesium/strontium (Cs/Sr)

capsules. Transport the casks. from the $\mathrm{Cs} / \mathrm{Sr}$ capsule disposal preparation system to the interim storage site. Remove the Cs/Sr capsules from the onsite transport casks and emplace in their designated storage locations. Control the Cs/Sr capsule storage

environment and monitor for containment integrity. Retrieve the $C s / S r$ capsules from their storage locations and prepare them for loading into onsite transport casks. Load

dispositioned $\mathrm{Cs} / \mathrm{Sr}$ capsules into casks, and load the casks onto transport vehicles.

Transport the casks containing dispositioned Cs/Sr capsules to a shipping cask loading station. Provide support services for the Interim Store Dispositioned $\mathrm{Cs} / \mathrm{Sr}$ Capsules function.
Outputs:

Dispositioned Cs/Sr Capsules for Disposal

Dispositioned Cs/Sr Capsules Storage Information

Dispositioned Cs/Sr Capsules Transport Mechanism

IS Dispositioned Cs/Sr Capsules Excess Facilities

IS Dispositioned Cs/Sr Capsules Garbage

IS Dispositioned Cs/Sr Capsules Hazardous Waste

IS Dispositioned Cs/Sr Capsules Prepared Solid Waste

IS Dispositioned Cs/Sr Capsules Treated Gaseous Effluents

IS Dispositioned Cs/Sr Capsules Treated Liquid Effluents

IS Dispositioned Cs/Sr Capsules Untreated Liquid Effluents 
Table 3-1. Functions and Inputs/Outputs. (14 sheets)

Inputs:

Cesium Product for Storage

Cesium Product Production Information

Infrastructure Support for IS Phase I Solidified HLW

Phase I IHLW for Storage

Phase I IHLW Production Information

Raw Materials for IS Phase I Solidified HLW

\subsubsection{2}

Interim Store Phase I Solidified HLW

Accept onsite transport casks loaded with Phase I solidified HLW (i.e., IHLW canisters or cesium product containers).

Transport the casks from the production facilities to the interim storage site. Remove Phase I solidified HLW from the onsite transport casks and emplace in their designated storage locations. Control Phase I solidified HLW storage environment and monitor for containment integrity. Retrieve Phase I solidified HLW from their storage locations and prepare them for loading into onsite transport casks. Load Phase $I$ solidified $H L W$ into casks, and load the casks onto transport vehicles. Transport casks containing cesium product to the HLW Immobilization

facility, and transfer cesium product container responsibility to the HLW Immobilization process. Transport casks containing $I H L W$ canisters to an onsite shipping cask loading station.
Outputs:

Cesium Product for Processing

Cesium Product Storage Information

Cesium Product Transport Mechanism

IS Phase I Solidified HLW Excess Facilities

IS Phase I Solidified HLW Garbage

IS Phase I Solidified HLW

Hazardous Waste

IS Phase I Solidified HLW Prepared Solid Waste

IS Phase I Solidified HLW Treated Gaseous Effluents

IS Phase I Solidified HLW Treated Liquid Effluents

IS Phase I Solidified HLW Untreated Liquid Effluents

Phase I IHLW for Disposal

Phase I IHLW Storage Information

Phase I IHLW Transport Mechanism 
Table 3-1. Functions and Inputs/0utputs. (14 sheets)

$$
\text { 4.2.4.1.2 }
$$

Interim Store Phase I Solidified HLW

(cont inued)

Provide support services for the Interim Store (IS) Phase I HLW function.

Subfunctions:

Accept Phase I Solidified HLW from Producers

Transport Phase I Solidified HLW to Interim Storage Isolate Phase I Sol idified HLW Retrieve Phase I Solidified HLW from Storage

Deliver Phase I Solidified HLW for Shipping or Processing Support Interim Store Phase I Solidified HLW 
Table 3-1. Functions and Inputs/0utputs. (14 sheets)

Inputs:

Cesium Product for Storage

Cesium Product Production Information

Phase I IHLW for Storage

Phase I IHLW Production

Information
4.2.4.1.2.1

Accept Phase I Solidified HLH from Producers

Verify that Phase I solidified

$H L W$ (i.e., sealed IHLW canisters

or sealed cesium product

containers) satisfy interim

storage acceptance requirements.

Verify that the Phase I IHLW

satisfies repository acceptance

requirements. Verify that the

sealed transport cask meets

onsite transportation

requirements. Accept

responsibility for the Phase I

solidified $H L W$ from the

producer. Collect system-

generated waste (SGW) for

disposition by the Support

Interim Store Phase I Solidified

HLW function. outputs:

Accept Phase I Solidified HLW from

Producers SGW

Accepted Cesium Product for

Transport

Accepted Phase I IHLW for

Transport

Cesium Product Acceptance

Documentation

Phase I IHLW Acceptance

Documentation 
Table 3-1. Functions and Inputs/Outputs. (14 sheets)

Inputs:

Accepted Cesium Product for Transport

Accepted Phase I IHLW for Transport
4.2.4.1.2.2

Transport Phase I Solidified HLK to Interim Storage

Transport onsite transportation casks, loaded with Phase I

solidified HLW, from the

production facilities to the

Phase I solidified HLW interim

storage facility. Collect

system-generated waste (SGW) for

disposition by the Support

Interim Store Phase I Solidified

$H L W$ function.
Outputs:

Cesium Product for Isolation

Phase I IHLW for Isolation

Transport Phase I Solidified HIW to Interim Storage SGW 
Table 3-1. Functions and Inputs/0utputs. (14 sheets)

Inputs:

Cesium Product for Isolation Phase I IHLW for I solation

$$
\text { 4.2.4.1.2.3 }
$$

Isolate Phase I Solidified HLW

Remove Phase I solidified HLW

from the onsite transportation casks, and release the casks and vehicle to the Support Interim Store Phase I Solidified HLW

function for reconditioning. Prepare Phase I solidified HLW

for interim storage. Move Phase I solidified HLW to interim storage locations, emplace, and isolate from the environment.

Control and monitor the storage environment and integrity of

storage location. Prevent and recover from accidents and abnormal situations during the interim storage period. Collect system-generated waste (SGW) for disposition by the Support

Interim Store Phase I Solidified $H L W$ function. outputs:

Cesium Product for Retrieval

Cesium Product Isolation Data

Cesium Product Transport Mechanism for Reconditioning

lsolate Phase I Solidified HLW SGW

Phase I IHLW for Retrieval

Phase I IHLW Isolation Data

Phase I IHLW Transport Mechanism for Reconditioning 
Table 3-1. Functions and Inputs/Outputs. (14 sheets)

Inputs:

Cesium Product for Retrieval

Phase I IHLW for Retrieval

$$
\text { 4.2.4.1.2.4 }
$$

Retrieve Phase I Solidified HLW from Storage

Remove Phase I solidified HLW

from their storage locations and

move them to the transport cask

loading location. Collect

system-generated waste (SGW) for disposition by the Support

Interim Store Phase I Solidified HIW function.
Outputs:

Retrieve Phase I Solidified HLW from Storage SGW Retrieved Cesium Product Retrieved Phase I IHLW 
Table 3-1. Functions and Inputs/Outputs. (14 sheets)

Inputs:

Cesium Product Transport Mechanism for Loading

Phase I IHLW Transport Mechanism for Loading

Retrieved Cesium Product

Retrieved Phase I IHLW

$$
\text { 4.2.4.1.2.5 }
$$

Deliver Phase I Solidified HLW for Shipping or Processing

Prepare Phase I solidified HLW for transport to an onsite HLW immobilization facility or shipping facility. Load Phase I solidified $\mathrm{HLW}$ into onsite transport casks, load the casks onto transport vehicle, and transport the casks to the designated receipt facility.

Collect system-generated waste (SGW) for disposition by the Support Interim Store Phase I Solidified $\mathrm{HLW}$ function.
Outputs :

Cesium Product for Processing

Cesium Product Transport Mechanism for Reuse

Deliver Phase I Solidified HLW for Shipping or Processing SGW

Phase I IHLW for Disposal

Phase I IHLW Transport Mechanism for Reuse 
Table 3-1. Functions and Inputs/Outputs. (14 sheets)

Inputs :

Accept Phase I Solidified HLW from Producers SGW

Cesium Product Acceptance

Documentation

Cesium Product Isolation Data

Cesium Product Transport Mechanism for Reconditioning

Cesium Product Transport Mechanism for Reuse

Deliver Phase I Solidified HLW for Shipping or Processing SGW

Infrastructure Support for IS Phase I Solidified HLW

Isolate Phase I Solidified HLW SGW

Phase I IHLW Acceptance Documentation

Phase I IHLW Isolation Data

$\stackrel{\omega}{\stackrel{1}{v}}$

Phase I IHLW Transport Mechanism for Reconditioning

Phase I IHLW Transport Mechanism for Reuse

Raw Materials for IS Phase I Solidified HLW

Retrieve Phase I Solidified HLW from Storage SGW

Transport Phase I Solidified HLW to Interim Storage SGW

\subsection{6}

Support Interim Store Phase I Solidified HLW

Provide support services for Phase I solidified HLW interim storage (IS). Services include heating, ventilation, and air conditioning (HVAC); electrical power distribution; instrument and service air; service water; maintenance services; receiving and storage of supplies and equipment; health

physics/operations support; cont aminated equipment repair shop; records management; and treatment, preparation,

packaging, discharge, etc. of system generated solid, liquid and gaseous effluents.
Outputs:

Cesium Product Storage Information Cesium Product Transport Mechanism Cesium Product Transport Mechanism for Loading

IS Phase I Solidified HLW Excess Facilities

IS Phase I Solidified HLW Garbage

IS Phase I Solidified HLW Hazardous Waste

IS Phase I Solidified HLW Prepared Solid Waste

IS Phase I Solidified HLW Treated Gaseous Effluents

IS Phase I Solidified HLW Treated Liquid Effluents

IS Phase I Solidified HLW Untreated Liquid Effluents

Phase I IHLW Storage Information

Phase I IHLW Transport Mechanism

Phase I IHLW Transport Mechanism for Loading 
Table 3-1. Functions and Inputs/Outputs. (14 sheets)

Inputs:

Infrastructure Support for IS

Phase II Solidified HLW and TRU

ITRU Waste for Storage

Phase II IHLW for Storage

Phase II Solidified HLW and TRU

Production Information

Raw Materials for IS Phase 11

Solidified HLW and TRU

\subsubsection{3}

Interim Store Phase II Solidified HLW and TRU Waste

Accept onsite transport casks loaded with Phase II solidified HLW/TRU (i.e., IHLW canisters or ITRU canisters). Transport the casks from the production facility to the interim storage

site. Remove Phase II

solidified HLW/TRU from the

onsite transport casks and

emplace in their designated

storage locations. Control

Phase II solidified HLW/TRU

storage environment and monitor

for containment integrity.

Retrieve Phase II solidified

$H L W / T R U$ from their designated

storage locations and prepare

them for loading into onsite

transport casks. Load Phase II

solidified HLW/TRU into casks,

and load the casks onto

transport vehicles. Transport

the casks containing IHLW or

ITRU canisters to an onsite

shipping cask loading station

Provide support services for the Interim Store (IS) Phase II

Solidified $H L W$ and TRU function.

\section{Outputs:}

IS Phase II Solidified HLW and TRU Excess Facilities

IS Phase II Solidified HLW and TRU Garbage

IS Phase II Solidified HLW and TRU Hazardous Waste

IS Phase II Solidified HLW and TRU Prepared Solid Waste

IS Phase II Solidified HLW and TRU Treated Gaseous Effluents

IS Phase II Solidified HLW and TRU Treated Liquid Effluents

IS Phase II Solidified HLW and TRU Untreated Liquid Effluents

ITRU for Disposal

Phase II IHLW for Disposal

Phase II Solidified HLW and TRU Storage Information

Phase II Solidified HLW and TRU Transport Mechanism 
Table 3-1. Functions and Inputs/Outputs. (14 sheets)

Inputs:

Dispositioned Cs/Sr Capsules for Disposal

Dispositioned Cs/Sr Capsules Shipping Mechanism

IHLW Repository Shipping Mechanism Infrastructure Support for Prepare

Solidified HLW and TRU for

Shipment

ITRU for Disposal

ITRU Repository Shipping Mechanism

Phase I IHLW for Disposal

Phase II IHLW for Disposal

Raw Materials for Prepare Solidified HLW and TRU for Shipment

$\stackrel{\omega}{1}$

\subsubsection{4 \\ Prepare Solidified HLW and TRU for Shipment}

Accept onsite transport casks loaded with solidified HLW/TRU destined for offsite shipment (i.e., dispositioned $\mathrm{Cs} / \mathrm{Sr}$ capsules, IHLW canisters, or ITRU canisters). Receive shipping casks furnished by the U.S. Department of Energy office of Civilian Radioactive Waste Management (DOE-OCRWM). Unload the solidified HLW/TRU from the onsite transport casks. Re-certify the solidified $H L W / T R U$ for repository acceptability. Load the solidified $H L W / T R U$ into shipping casks, load the shipping casks onto shipping vehicles, and transfer responsibility to the DOE-OCRWM. The DOE-OCRWM, upon taking receipt of the shipping casks loaded with dispositioned Cs/Sr capsules, IHLW, and ITRU, ships the casks to their final disposition.
Outputs:

Dispositioned Cs/Sr Capsules for

Shipment

IHLW for Shipment

ITRU for Shipment

Prepare Solidified HLW and TRU for Shipment Excess Facilities

Prepare Solidified HLW and TRU for Shipment Garbage

Prepare Solidified HLW and TRU for Shipment Hazardous Waste

Prepare Solidified HLW and TRU for Shipment Prepared Sol id Waste

Prepare Solidified HLW and TRU for Shipment Treated Gaseous Effluents

Prepare Solidified HLW and TRU for Shipment Treated Liquid

Effluents

Prepare Solidified HLW and TRU for Shipment Untreated Liquid Effluents

Solidified HLW and TRU

Recertification Information 
WHC-SD-WM-FRD-027, Rev. 0

This page intentionally left blank. 
WHC-SD-WM-FRD-027 Rev. 0

\subsection{INTERFACES}

\subsection{INTERFACE IDENT IFICATION}

Interfaces are $i$ tems entering a function to be acted upon by that function (inputs), and items leaving a function after having been acted upon by that function (outputs). The inputs to and outputs from each of the functions addressed in this document are identified in Table 3-1.

\subsection{INTERFACE DESCRIPTION}

Table 4-1 provides descriptions of the inputs and outputs identified in Table 3-1. 
Table 4-1. Input and Output Descriptions. (13 sheets)

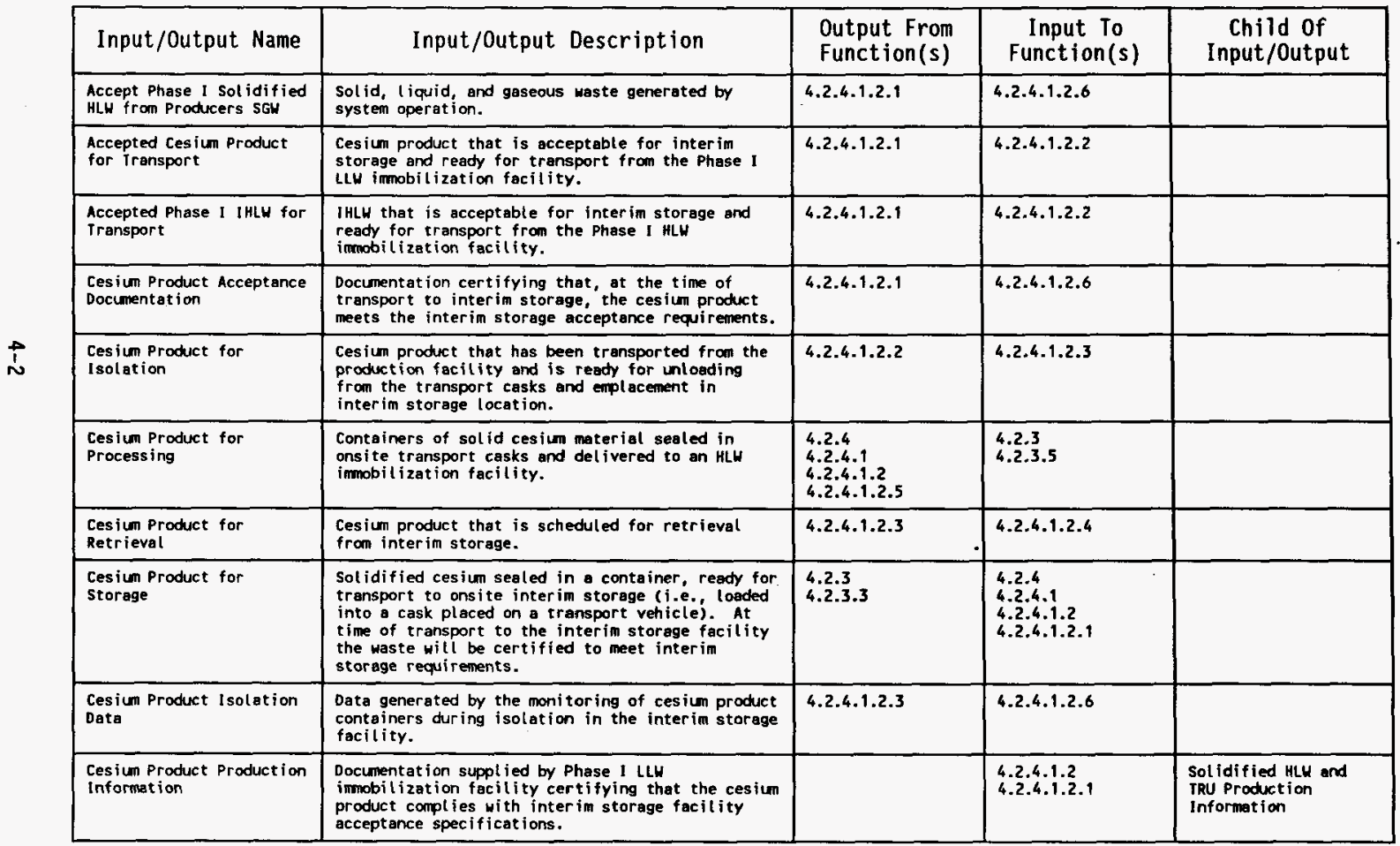


Table 4-1. Input and Output Descriptions. (13 sheets)

\begin{tabular}{|c|c|c|c|c|}
\hline Input/Output Name & Input/Output Description & $\begin{array}{l}\text { Output From } \\
\text { Function }(s)\end{array}$ & $\begin{array}{c}\text { Input To } \\
\text { Function(s) }\end{array}$ & $\begin{array}{l}\text { Child of } \\
\text { Input/Output }\end{array}$ \\
\hline $\begin{array}{l}\text { Cesium Product storage } \\
\text { information }\end{array}$ & $\begin{array}{l}\text { Documentation supplied by the Phase I solidified } \\
\text { HLW interim storage facility certifying that the } \\
\text { cesium product was stored in accordance with } \\
\text { inter im storage specifications. }\end{array}$ & $\begin{array}{l}4.2 .4 \cdot 1.2 \\
4.2 .4 \cdot 1.2 .6\end{array}$ & & $\begin{array}{l}\text { Solidified HLW and } \\
\text { TRU Storage } \\
\text { Information }\end{array}$ \\
\hline $\begin{array}{l}\text { Cesium Product Iransport } \\
\text { Mechanism }\end{array}$ & $\begin{array}{l}\text { The ready- to-use cask and vehicle for on-site } \\
\text { transport of cesium product from the Phase I LLW } \\
\text { lmmobilization Facilitity to the interim storage } \\
\text { facility. The transport mechanism is provided by } \\
\text { the Interim store Sol idified HLH and TRU Uaste } \\
\text { function }(4.2 .4 .1) \text {. }\end{array}$ & $\begin{array}{l}4.2 .4 \\
4.2 .4 .1 \\
4.2 .4 .1 .2 \\
4.2 .4 .1 .2 .6\end{array}$ & 4 & \\
\hline $\begin{array}{l}\text { Cesium Product Iransport } \\
\text { Mechanism for Loding }\end{array}$ & $\begin{array}{l}\text { Empty cesium product transport vehicle and casks, } \\
\text { ready for loading with retrieved cesium product. }\end{array}$ & 4.2 .4 .1 .2 .6 & 4.2 .4 .1 .2 .5 & \\
\hline $\begin{array}{l}\text { Cesium Product Transport } \\
\text { Mechanism for } \\
\text { Reconditioning }\end{array}$ & $\begin{array}{l}\text { Empty cesium product transport vehicle and casks, } \\
\text { ready for maintenance after transporting the } \\
\text { product from the producer's facility to interim } \\
\text { storage. }\end{array}$ & 4.2 .4 .1 .2 .3 & 4.2 .4 .1 .2 .6 & \\
\hline $\begin{array}{l}\text { Cesium Product Iransport } \\
\text { Mechanism for Reuse }\end{array}$ & $\begin{array}{l}\text { Empty cesium product transport vehicle and casks, } \\
\text { ready for ma intenance after trensporting the } \\
\text { product from interim storage to the HLW } \\
\text { immobilization facility. }\end{array}$ & 4.2 .4 .1 .2 .5 & 4.2 .4 .1 .2 .6 & \\
\hline $\begin{array}{l}\text { Dispositioned Cs/Sr } \\
\text { Capsules for D isposal }\end{array}$ & $\begin{array}{l}\text { Dispositioned Cs/Sr capsules delivered from the } \\
\text { interim storage facility to the shipping cask } \\
\text { loading station. }\end{array}$ & 4.2 .6 .1 .1 & 4.2 .4 .1 .4 & \\
\hline $\begin{array}{l}\text { Dispositioned Cs/Sr } \\
\text { Capsules for Shipment }\end{array}$ & $\begin{array}{l}\text { Cs/Sr capsules prepared to meet repository } \\
\text { acceptance requirements, loaded into the shipping } \\
\text { mechanism for shipnent to the repository. }\end{array}$ & $\begin{array}{l}0 \\
4 \\
4.2 \\
4.2 .4 \\
4.2 .4 .1 \\
4.2 .4 .1 .4\end{array}$ & External & \\
\hline $\begin{array}{l}\text { Dispositioned Cs/Sr } \\
\text { Capsules for Storage }\end{array}$ & $\begin{array}{l}\text { Cs/Sr capsules dispositioned in a manner suitable } \\
\text { for interim onsite storage and eventual of fsite } \\
\text { disposal. }\end{array}$ & $\begin{array}{l}4.2 .3 \\
4.2 .3 .6 \\
4.2 .3 .6 .3 \text { orig. }\end{array}$ & $\begin{array}{l}4.2 .4 \\
4.2 .4 .1 \\
4.2 .4 .1 .1\end{array}$ & \\
\hline
\end{tabular}


Table 4-1. Input and Output Descriptions. (13 sheets)

\begin{tabular}{|c|c|c|c|c|}
\hline Input/Output Name & Input/0utput Description & $\begin{array}{l}\text { Output From } \\
\text { Function (s) }\end{array}$ & $\begin{array}{c}\text { Input To } \\
\text { Function }(s)\end{array}$ & $\begin{array}{l}\text { Child of } \\
\text { Input/Output }\end{array}$ \\
\hline $\begin{array}{l}\text { Dispositioned Cs/Sr } \\
\text { Capsules Product ion } \\
\text { Information }\end{array}$ & $\begin{array}{l}\text { Documentation supplied by the Cs/Sr capsule } \\
\text { disposal preparation system certifying that the } \\
\text { dispositioned Cs/Sr capsules comply with interim } \\
\text { storage facility acceptance specifications. Those } \\
\text { specifications will include HLW geologic } \\
\text { repository acceptance criteria. }\end{array}$ & & 4.2 .4 .1 .1 & $\begin{array}{l}\text { Sol idified HLW and } \\
\text { TRU Production } \\
\text { Information }\end{array}$ \\
\hline $\begin{array}{l}\text { Dispositioned Cs/Sr } \\
\text { Capsules Sh ipping } \\
\text { Mechanism }\end{array}$ & $\begin{array}{l}\text { The shipping cask and vehicle provided by } \\
\text { DOE-OCRLM for the shipment of containers of } \\
\text { dispositioned cs/Sr capsule product to the } \\
\text { geologic repository. }\end{array}$ & External & $\begin{array}{l}0 \\
4 \\
4.2 \\
4.2 .4 \\
4.2 .4 .1 \\
4.2 .4 .1 .4\end{array}$ & \\
\hline $\begin{array}{l}\text { Dispositioned Cs/Sr } \\
\text { Capsules Storage } \\
\text { Information }\end{array}$ & $\begin{array}{l}\text { Documentation supplied by the dispositioned } \mathrm{Cs/Sr} \\
\text { capsule interim storge facility certifying that } \\
\text { containers were stored in accordance with interim } \\
\text { storage specifications. }\end{array}$ & 4.2 .4 .1 .1 & & $\begin{array}{l}\text { Solidified HLW and } \\
\text { IRU Storage } \\
\text { Information }\end{array}$ \\
\hline $\begin{array}{l}\text { Dispositioned Cs/Sr } \\
\text { Capsules Transport } \\
\text { Mechanism }\end{array}$ & $\begin{array}{l}\text { The ready-to-use cask and vehicle for on-site } \\
\text { transport of dispositioned cs/Sr capsules from the } \\
\text { capsule preparation system to the interim storage } \\
\text { facility. The transport mechanism is provided by } \\
\text { the Interim Store Sol idified HLW and TRU Waste } \\
\text { function (4.2.4.1). }\end{array}$ & $\begin{array}{l}4.2 .4 \\
4.2 .4 .1 \\
4.2 .4 .1 .1\end{array}$ & $\begin{array}{l}4.2 .3 \\
4.2 .3 .6 \\
4.2 .3 .6 .3 \text { orig. }\end{array}$ & \\
\hline IHLW for Shipment & $\begin{array}{l}\text { Sealed containers of IHLW that are placed in } \\
\text { of fsite shipping casks and loaded onto a vehicle } \\
\text { for shipment to the repository by doE-OCRLim } \\
\text { personnel. The waste will be accompanied by the } \\
\text { required characterization information. At the } \\
\text { time of shipment to the repository, the waste will } \\
\text { be certified to meet repository acceptance } \\
\text { requirements. }\end{array}$ & $\begin{array}{l}0 \\
4.2 \\
4.2 .4 \\
4.2 .4 .1 \\
4.2 .4 .1 .4\end{array}$ & External & \\
\hline IHLW for Storage & $\begin{array}{l}\text { IHLW sealed in canisters suitable for inter im } \\
\text { onsite storage and eventual emplacement in HLW } \\
\text { geol ogic repository. At time of transport to the } \\
\text { interim storage facility the waste will be } \\
\text { certified to meet repository acceptance } \\
\text { requirements. }\end{array}$ & $\begin{array}{l}4.2 .3 \\
4.2 .3 .5 \\
4.2 .3 .5 .1 \\
4.2 .3 .5 .1 .5\end{array}$ & 4.2 .4 & \\
\hline
\end{tabular}


Table 4-1. Input and Output Descriptions. (13 sheets)

\begin{tabular}{|c|c|c|c|c|}
\hline Input/Output Name & Input/Output Description & $\begin{array}{l}\text { Output From } \\
\text { Function(s) }\end{array}$ & $\begin{array}{c}\text { Input To } \\
\text { Function(s) }\end{array}$ & $\begin{array}{l}\text { Child of } \\
\text { Input/Output }\end{array}$ \\
\hline $\begin{array}{l}\text { IHLL Repository Shipping } \\
\text { Mechanism }\end{array}$ & $\begin{array}{l}\text { The shipping cask and vehicle provided by } \\
\text { DOE-OCRLM for the shipment of sealed IHLW } \\
\text { containers to the geologic repository. }\end{array}$ & External & $\begin{array}{l}0 \\
4 \\
4.2 \\
4.2 .4 \\
4.2 .4 .1 \\
4.2 .4 \cdot 1.4\end{array}$ & \\
\hline $\begin{array}{l}\text { Infrastructure Support } \\
\text { for } 15 \text { Dispositioned } \\
\text { cs/sr Capsules }\end{array}$ & $\begin{array}{l}\text { General infrastructure support needed to inter im } \\
\text { store dispositioned cs/sr capsules. This will } \\
\text { include but is not limited to fire protection, } \\
\text { pol ice, emergency preparedness, medical services, } \\
\text { road services, telecormenications, radiological } \\
\text { services, laboratory services, transportation, and } \\
\text { sewer. This includes land for siting facilities. }\end{array}$ & & 4.2 .4 .1 .1 & $\begin{array}{l}\text { Infrastructure } \\
\text { Support for IS } \\
\text { Solidified HLW and } \\
\text { IRU }\end{array}$ \\
\hline $\begin{array}{l}\text { Infrastructure Support } \\
\text { for IS Phase I Solidified } \\
\text { HLW }\end{array}$ & $\begin{array}{l}\text { General infrastructure support needed to interim } \\
\text { store Phase I sol idfied hLw. This will include } \\
\text { but is not } L \text { imited to fire protect ion, pol ice, } \\
\text { emergency preparechess, medical services, road } \\
\text { services, telecommications, radiological } \\
\text { services, transportation, and seever. This } \\
\text { includes tand for siting facilities. }\end{array}$ & & $\begin{array}{l}4.2 .4 .1 .2 \\
4.2 .4 .1 .2 .6\end{array}$ & $\begin{array}{l}\text { Infrastructure } \\
\text { Support for Is } \\
\text { Solidified HLU and } \\
\text { TRU }\end{array}$ \\
\hline $\begin{array}{l}\text { Infrastructure Support } \\
\text { for IS Sol idified HLW and } \\
\text { TRU }\end{array}$ & $\begin{array}{l}\text { General infrastructure support needed to interim } \\
\text { store sol idified HLW and TRU waste. This will } \\
\text { include but is not limi ted to fire protection, } \\
\text { pol ice, emergency preparedness, medical services, } \\
\text { road services, telecommenications, radiological } \\
\text { services, laboratory services, transportation, and } \\
\text { sewer. This includes land for siting facilities. }\end{array}$ & & 4.2 .4 .1 & $\begin{array}{l}\text { Infrastructure } \\
\text { Support for Dispose } \\
\text { Waste }\end{array}$ \\
\hline
\end{tabular}


Table 4-1. Input and Output Descriptions. (13 sheets)

\begin{tabular}{|c|c|c|c|c|}
\hline Input/Output Name & Input/Output Description & $\begin{array}{l}\text { Output From } \\
\text { Function(s) }\end{array}$ & $\begin{array}{l}\text { Input To } \\
\text { Function (s) }\end{array}$ & $\begin{array}{l}\text { Child of } \\
\text { Input/Output }\end{array}$ \\
\hline $\begin{array}{l}\text { Infrastructure Support } \\
\text { for Prepare Sol idified } \\
\text { HLH and TRU for Shipment }\end{array}$ & $\begin{array}{l}\text { General infrastructure support needed to prepare } \\
\text { solidified HLW for shipment to an offsite disposal } \\
\text { site. This will include but is not I imited to } \\
\text { fire protection, pol ice, emergency preparedness, } \\
\text { medical services, road services, } \\
\text { telecommunications, radiological services, } \\
\text { laboratory services, transportation, and sewer. } \\
\text { This includes land for siting facilities. }\end{array}$ & & 4.2 .4 .1 .4 & $\begin{array}{l}\text { Infrastructure } \\
\text { Support for is } \\
\text { Solidified HLW and } \\
\text { TRU }\end{array}$ \\
\hline $\begin{array}{l}\text { 1S Dispositioned } \mathrm{Cs} / \mathrm{Sr} \\
\text { Capsules Excess } \\
\text { Facilities }\end{array}$ & $\begin{array}{l}\text { Facilities that, having fulfilled their original } \\
\text { purposes and completed the function/processes } \\
\text { described in the Interim Store Dispositioned Cs/Sr } \\
\text { Capsules function, are now available and } \\
\text { appropriate for reuse or deactivation. }\end{array}$ & 4.2 .4 .1 .1 & & $\begin{array}{l}\text { Is Solidified } h L U \text { and } \\
\text { IRU Excess Facilities }\end{array}$ \\
\hline $\begin{array}{l}\text { Is Dispositioned } \mathrm{Cs} / \mathrm{Sr} \\
\text { Capsules Garbage }\end{array}$ & $\begin{array}{l}\text { Ordinary nonradioactive, nonhazardous sol id waste } \\
\text { generated with in the Interim Store Cs/Sr Capsules } \\
\text { function. suitable for disposal in a sanitary } \\
\text { landfill. }\end{array}$ & 4.2 .4 .1 .1 & & $\begin{array}{l}\text { IS Solidified HLH and } \\
\text { TRU Garbage }\end{array}$ \\
\hline $\begin{array}{l}\text { IS Dispositioned Cs/Sr } \\
\text { Capsules Hazardous Waste }\end{array}$ & $\begin{array}{l}\text { Solid waste generated within the Interim Store } \\
\text { Dispositioned Cs/Sr Capsules function that is } \\
\text { classified as hazardous (dangerous) per EPA or } \\
\text { State of Washington regulations. }\end{array}$ & 4.2 .4 .1 .1 & & $\begin{array}{l}\text { IS Solidified HLW and } \\
\text { IRU Waste Mazardous } \\
\text { Waste }\end{array}$ \\
\hline $\begin{array}{l}\text { IS Dispositioned Cs/Sr } \\
\text { Capsules Prepared Solid } \\
\text { Waste }\end{array}$ & $\begin{array}{l}\text { Solid waste, generated from the Inter im store } \\
\text { Dispositioned CS/Sr Capsules function, that has } \\
\text { been segregated, packaged, assayed, and certified } \\
\text { for transfer to Hanford site function } 4.3, \text { Remedy } \\
\text { Sol id Waste, for further treatment or disposal. } \\
\text { This includes mixed and radioactive wastes. }\end{array}$ & 4.2 .4 .1 .1 & & $\begin{array}{l}\text { is solidified HLW and } \\
\text { TRU Prepared Solid } \\
\text { Uaste }\end{array}$ \\
\hline $\begin{array}{l}\text { IS Dispositioned } \mathrm{Cs} / \mathrm{Sr} \\
\text { Capsules Ireated Gaseous } \\
\text { Effluents }\end{array}$ & $\begin{array}{l}\text { Treated gaseous waste from functions as sociated } \\
\text { with the interim storage of dispositianed } \mathrm{Cs} / \mathrm{Sr} \\
\text { capsules. Ireated gaseous eff luents are } \\
\text { discharged to the atmosphere. }\end{array}$ & 4.2 .4 .1 .1 & & $\begin{array}{l}\text { IS Solidified HLW and } \\
\text { TRU Treated Gaseous } \\
\text { Effluents }\end{array}$ \\
\hline $\begin{array}{l}\text { is Dispositioned Cs/Sr } \\
\text { Capsules Ireated Liquid } \\
\text { Effluents }\end{array}$ & $\begin{array}{l}\text { Liquid effluents which meet interface acceptance } \\
\text { criteria for discharge directly to the } 200 \text { Area } \\
\text { Treated Effluent Disposal Facility (IED). }\end{array}$ & 4.2 .4 .1 .1 & & $\begin{array}{l}\text { Is Solidified HLW and } \\
\text { IRU Treated Liquid } \\
\text { Effluents }\end{array}$ \\
\hline
\end{tabular}


Table 4-1. Input and Output Descriptions. (13 sheets)

\begin{tabular}{|c|c|c|c|c|}
\hline Input/Output Name & Input/Output Description & $\begin{array}{l}\text { Output From } \\
\text { Function(s) }\end{array}$ & $\begin{array}{l}\text { Input To } \\
\text { Function(s) }\end{array}$ & $\begin{array}{l}\text { Child of } \\
\text { Input/Output }\end{array}$ \\
\hline $\begin{array}{l}\text { IS Dispositioned } \mathrm{Cs} / \mathrm{Sr} \\
\text { Capsules Untreated Liquid } \\
\text { Effluents }\end{array}$ & $\begin{array}{l}\text { Generated liquid effluents which require treatment } \\
\text { and meet interface acceptance criteria for } \\
\text { discharge directly to the Liquid Effluent } \\
\text { Retention facility (LERF) and subsequent treatment } \\
\text { in the Effluent Treatment Facility (EIF). }\end{array}$ & 4.2 .4 .1 .1 & & $\begin{array}{l}\text { Is Solidified HLH and } \\
\text { IRU Untreated Liquid } \\
\text { Effluents }\end{array}$ \\
\hline $\begin{array}{l}\text { IS Phase I Solidified HLW } \\
\text { Excess Facilities }\end{array}$ & $\begin{array}{l}\text { Facilities that, having fulfilled their original } \\
\text { purposes and completed the function/processes } \\
\text { described in the interim store Phose I solfidified } \\
\text { HLW function, are now available and appropriate } \\
\text { for reuse or deact ivation. }\end{array}$ & $\begin{array}{l}4.2 .4 .1 .2 \\
4.2 .4 .1 .2 .6\end{array}$ & & $\begin{array}{l}\text { Is Sol idified HLH and } \\
\text { TRU Excess Facilities }\end{array}$ \\
\hline $\begin{array}{l}\text { I5 Phase I Solidified HLW } \\
\text { Garbage }\end{array}$ & $\begin{array}{l}\text { Ordinary nonradioactive, nonhazardous solid waste } \\
\text { generated within the Interim store Phase I } \\
\text { Solidified HLW function, suitable for disposal in } \\
\text { a sanitary landfill. }\end{array}$ & $\begin{array}{l}4.2 .4 \cdot 1.2 \\
4.2 .4 \cdot 1.2 .6\end{array}$ & & $\begin{array}{l}\text { Is Sol idified HLH and } \\
\text { TRU Gerbage }\end{array}$ \\
\hline $\begin{array}{l}\text { 1S Phase I Solidified HLH } \\
\text { Hazardous Naste }\end{array}$ & $\begin{array}{l}\text { Solid waste generated within the Inter im Store } \\
\text { Phase I Solidified HLW function that is classified } \\
\text { as hazardous (dangerous) per EPA or State of } \\
\text { Washington regulations. }\end{array}$ & $\begin{array}{l}4.2 .4 .1 .2 \\
4.2 .4 .1 .2 .6\end{array}$ & & $\begin{array}{l}\text { IS Sol idified HLW and } \\
\text { IRU Waste Hazardous } \\
\text { Waste }\end{array}$ \\
\hline $\begin{array}{l}\text { Is Phase I Solidified HLW } \\
\text { Prepared Solid Waste }\end{array}$ & $\begin{array}{l}\text { Solid waste, generated from the Interim store } \\
\text { Phase I Sol idified HLW function, that has been } \\
\text { segregated, packaged, assayed, and cert ified for } \\
\text { transfer to Hanford Si te Function } 4.3 \text {. Remedy } \\
\text { Sol id Waste, for further treatment or disposal. } \\
\text { This includes mixed and radioact ive wastes. }\end{array}$ & $\begin{array}{l}4.2 .4 .1 .2 \\
4.2 .4 .1 .2 .6\end{array}$ & & $\begin{array}{l}\text { IS Solidified HLW and } \\
\text { IRU Prepared Sol id } \\
\text { Waste }\end{array}$ \\
\hline $\begin{array}{l}\text { IS Phase I Solidified HLW } \\
\text { Treated Gaseous Effluents }\end{array}$ & $\begin{array}{l}\text { Treated gaseous waste from functions associated } \\
\text { with the inter im storage of Phase I sol idified } \\
\text { MLU. Treated gaseous eff luents are discharged to } \\
\text { the atmosphere. }\end{array}$ & $\begin{array}{l}4.2 .4 .1 .2 \\
4.2 .4 .1 .2 .6\end{array}$ & & $\begin{array}{l}\text { Is Solidified HLH and } \\
\text { IRU Treated Gaseous } \\
\text { Effluents }\end{array}$ \\
\hline $\begin{array}{l}\text { IS Phase I Solidified HLU } \\
\text { Ireated Liquid Effluents }\end{array}$ & $\begin{array}{l}\text { Liquid effluents which meet interface acceptance } \\
\text { criteria for discharge directly to the } 200 \text { Area } \\
\text { Treated Effluent Disposal Facility (TEDF). }\end{array}$ & $\begin{array}{l}4.2 .4 .1 .2 \\
4.2 .4 .1 .2 .6\end{array}$ & & $\begin{array}{l}\text { IS Solidified HLH and } \\
\text { IRU Treated Liquid } \\
\text { Effluents }\end{array}$ \\
\hline $\begin{array}{l}\text { IS Phase I Solidified HLW } \\
\text { Unt reated Liquid } \\
\text { Effluents }\end{array}$ & $\begin{array}{l}\text { Generated liquid effluents which require treatment } \\
\text { and meet interface acceptance criteria for } \\
\text { discharge directly to the Liquid Effluent } \\
\text { Retention Facility (LERF) and subsequent treatment } \\
\text { in the Effluent Treatment Facility (ETF). }\end{array}$ & $\begin{array}{l}4.2 .4 .1 .2 \\
4.2 .4 .1 .2 .6\end{array}$ & & $\begin{array}{l}\text { Is Solidified HLW and } \\
\text { IRU Untreated Liquid } \\
\text { Effluents }\end{array}$ \\
\hline
\end{tabular}


Table 4-1. Input and Output Descriptions. (13 sheets)

\begin{tabular}{|c|c|c|c|c|}
\hline Input/Output Name & Input/Output Description & $\begin{array}{l}\text { Output From } \\
\text { Function(s) }\end{array}$ & $\begin{array}{c}\text { Input To } \\
\text { Function }(s)\end{array}$ & $\begin{array}{l}\text { Child of } \\
\text { Input/Output }\end{array}$ \\
\hline $\begin{array}{l}\text { 15 Phase } 11 \text { Solidified } \\
\text { HLU and TRU Excess } \\
\text { Facilities }\end{array}$ & $\begin{array}{l}\text { Facilities that, having fulfilled their original } \\
\text { purposes and completed the funct ion/processes } \\
\text { described in the Interim store Phase II Sol idified } \\
\text { HLW and TRU function, are now available and } \\
\text { appropriate for reuse or deactivation. }\end{array}$ & 4.2 .4 .1 .3 & & $\begin{array}{l}\text { Is Solidified HLH and } \\
\text { IRU and IRU Excess } \\
\text { Facilities }\end{array}$ \\
\hline $\begin{array}{l}\text { Is Phase II Solidified } \\
\text { HLW and TRU Garbage }\end{array}$ & $\begin{array}{l}\text { Ordinary nonradioactive, nonhazardous sol id waste } \\
\text { generated within the Interim Store Phase II } \\
\text { Sol } \text { Idified }_{\text {HLW }} \text { and TRU function, suitable for } \\
\text { disposal in a sani tary landfill. } \\
\end{array}$ & 4.2 .4 .1 .3 & & $\begin{array}{l}\text { Is sol idified HLW and } \\
\text { TRU and TRU Garbage }\end{array}$ \\
\hline $\begin{array}{l}\text { Is Phase II Solidified } \\
\text { MLU and IRU Prepared } \\
\text { Sol id Waste }\end{array}$ & 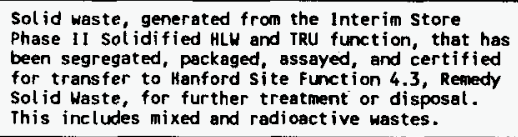 & 4.2 .4 .1 .3 & & $\begin{array}{l}\text { IS Sol idified HLW and } \\
\text { TRU and TRU Prepered } \\
\text { Sol id Haste }\end{array}$ \\
\hline $\begin{array}{l}\text { Is Phase II Solidified } \\
\text { HLW and TRU treated } \\
\text { Liquid Ef fluents }\end{array}$ & $\begin{array}{l}\text { Liquid effluents which meet interface acceptance } \\
\text { criteria for discharge directly to the } 200 \text { Area } \\
\text { Treated Effluent Disposal Facility (TEDF). }\end{array}$ & 4.2 .4 .1 .3 & & $\begin{array}{l}\text { Is solidified HLW and } \\
\text { TRU and TRU Treated } \\
\text { Liquid Effluents }\end{array}$ \\
\hline $\begin{array}{l}\text { Is Phase II Solidified } \\
\text { HLW and IRU Untreated } \\
\text { Liquid Effluents }\end{array}$ & $\begin{array}{l}\text { Generated liquid effluents which require treatment } \\
\text { and meet interface acceptance criteria for } \\
\text { discharge directly to the Liquid Effluent } \\
\text { Retention facitity (LER) and subsequent treatment } \\
\text { in the Effluent Treatment facility (ETF). }\end{array}$ & 4.2 .4 .1 .3 & & $\begin{array}{l}\text { IS Solidified HLH and } \\
\text { IRU Untreated Liquid } \\
\text { Effluents }\end{array}$ \\
\hline
\end{tabular}


Table 4-1. Input and Output Descriptions. (13 sheets)

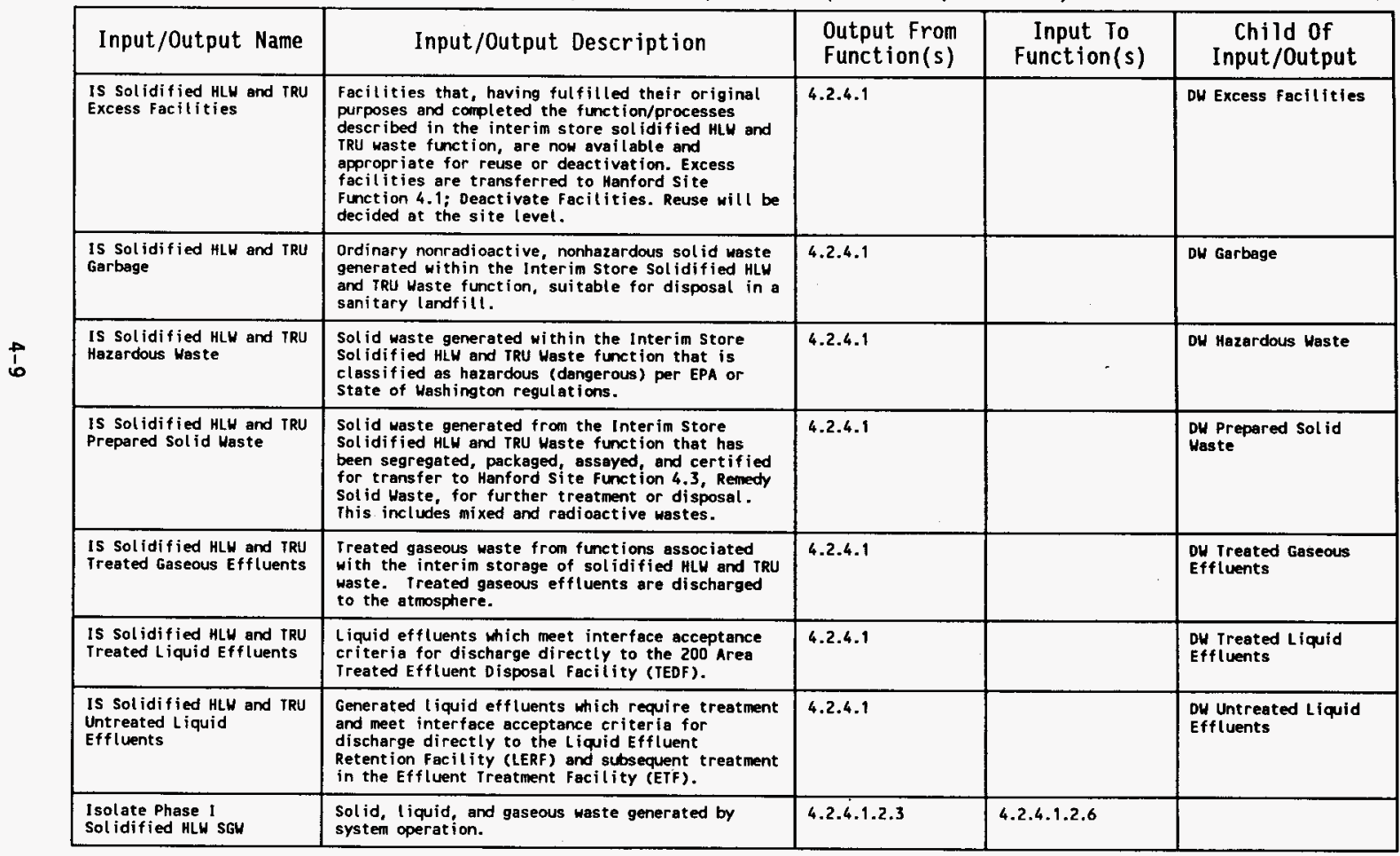


Table 4-1. Input and Output Descriptions. (13 sheets)

\begin{tabular}{|c|c|c|c|c|}
\hline Input/Output Name & Input/Output Description & $\begin{array}{l}\text { Output From } \\
\text { Function }(s)\end{array}$ & $\begin{array}{c}\text { Input To } \\
\text { Function(s) }\end{array}$ & $\begin{array}{c}\text { Child of } \\
\text { Input/Output }\end{array}$ \\
\hline ITRU for Disposal & $\begin{array}{l}\text { ITRU delivered from the interim storage facility } \\
\text { to the shipping cask loading station. }\end{array}$ & 4.2 .4 .1 .3 & 4.2 .4 .1 .4 & \\
\hline ITRU for Storage & $\begin{array}{l}\text { IIRU sealed in canisters suitable for inter im } \\
\text { storage end eventual emplacement in UIPP or HLW } \\
\text { geol ogic repository (as required). The IIRU will } \\
\text { be certified to meet HIPP/HLW geologic repository } \\
\text { acceptance at time of transport to the inter im } \\
\text { storage facitity. }\end{array}$ & $\begin{array}{l}4.2 .3 \\
4.2 .3 .5 \\
4.2 .3 .5 .1 \\
4.2 .3 .5 .1 .5\end{array}$ & $\begin{array}{l}4.2 .4 \\
4.2 .4 .1 \\
4.2 .4 .1 .3\end{array}$ & \\
\hline $\begin{array}{l}\text { ITRU Repository Shipping } \\
\text { Mechanism }\end{array}$ & $\begin{array}{l}\text { The shipping cask and vehicle for the shipment of } \\
\text { sealed ITRU containers to the WIPP. }\end{array}$ & External & $\begin{array}{l}0 \\
4 \\
4.2 \\
4.2 .4 \\
4.2 .4 .1 \\
4.2 .4 .1 .4\end{array}$ & \\
\hline Phase I IHLU for Disposal & $\begin{array}{l}\text { Phase } 1 \text { 1HL delivered from the interim storage } \\
\text { facility to the shipping cask loading station. }\end{array}$ & $\begin{array}{l}4.2 .4 .1 .2 \\
4.2 .4 .1 .2 .5 \\
\end{array}$ & 4.2 .4 .1 .4 & \\
\hline $\begin{array}{l}\text { Phase I IHLW for } \\
\text { Isolation }\end{array}$ & $\begin{array}{l}\text { Phase I I HL that has been transported from the } \\
\text { product ion facility and is ready for unloading } \\
\text { from the transport casks and emplacement in } \\
\text { interim storage location. }\end{array}$ & 4.2 .4 .1 .2 .2 & 4.2 .4 .1 .2 .3 & \\
\hline $\begin{array}{l}\text { Phase I IHLW for } \\
\text { Retrieval }\end{array}$ & $\begin{array}{l}\text { Phase } 1 \text { 1HLW that is scheduled for retrieval from } \\
\text { interim storage. }\end{array}$ & 4.2 .4 .1 .2 .3 & 4.2 .4 .1 .2 .4 & \\
\hline
\end{tabular}


Table 4-1. Input and Output Descriptions. (13 sheets)

\begin{tabular}{|c|c|c|c|c|}
\hline Input/Output Name & Input/0utput Description & $\begin{array}{l}\text { Output From } \\
\text { Function }(s)\end{array}$ & $\begin{array}{c}\text { Input To } \\
\text { Function (s) }\end{array}$ & $\begin{array}{l}\text { Child of } \\
\text { Input/Output }\end{array}$ \\
\hline Phase I IHLW for Storage & $\begin{array}{l}\text { IHLL from the Phase I HLW immobilization facility, } \\
\text { sealed in canisters suitable for inter im onsite } \\
\text { storage and eventual emplacement in HLW geologic } \\
\text { repository. At time of transport to the interim } \\
\text { storage facility the waste will be certified to } \\
\text { meet repository acceptance requirements. }\end{array}$ & & $\begin{array}{l}4.2 .4 .1 .2 \\
4.2 .4 .1 .2 .1\end{array}$ & IHLW for Storage \\
\hline $\begin{array}{l}\text { Phase } 1 \text { IHLW Isolation } \\
\text { Data }\end{array}$ & $\begin{array}{l}\text { Data generated by the monitoring of Phase I I HLW } \\
\text { canisters during isolation in the interim storage } \\
\text { facility. }\end{array}$ & 4.2 .4 .1 .2 .3 & 4.2 .4 .1 .2 .6 & \\
\hline $\begin{array}{l}\text { Phase I I HLW Storage } \\
\text { Information }\end{array}$ & $\begin{array}{l}\text { Documentation supplied by the Phase I Solidified } \\
\text { HLW interim storage facility certifying that the } \\
\text { Phase I IHLH was stored in accordance with interim } \\
\text { storage specifications. }\end{array}$ & $\begin{array}{l}4.2 .4 .1 .2 \\
4.2 .4 .1 .2 .6\end{array}$ & & $\begin{array}{l}\text { Solidified } H L W \text { and } \\
\text { TRU Storage } \\
\text { Information }\end{array}$ \\
\hline $\begin{array}{l}\text { Phase I IHLW Transport } \\
\text { Mechanism for Loading }\end{array}$ & $\begin{array}{l}\text { Empty Phase I iHLW transport vehicle and casks, } \\
\text { ready for looding with retrieved Phase I IHLH. }\end{array}$ & 4.2 .4 .1 .2 .6 & 4.2 .4 .1 .2 .5 & \\
\hline $\begin{array}{l}\text { Phase I IHLW Transport } \\
\text { Mechanism for } \\
\text { Reconditioning }\end{array}$ & $\begin{array}{l}\text { Empty Phase } 1 \text { IHLW transport vehicle and casks, } \\
\text { ready for maintenance after transporting the } \\
\text { product from the producer's facility to inter im } \\
\text { storage. }\end{array}$ & $4.2 .4 \cdot 1.2 .3$ & 4.2 .4 .1 .2 .6 & \\
\hline $\begin{array}{l}\text { Phase I IHLW Transport } \\
\text { Mechani sm for Reuse }\end{array}$ & $\begin{array}{l}\text { Empty Phase } 1 \text { iHLW transport vehicle and casks, } \\
\text { ready for maintenance after transporting the } \\
\text { product from interim storage to the shipping cask } \\
\text { loading station. }\end{array}$ & 4.2 .4 .1 .2 .5 & 4.2 .4 .1 .2 .6 & \\
\hline $\begin{array}{l}\text { Phase } 11 \text { IHLW for } \\
\text { Disposal }\end{array}$ & $\begin{array}{l}\text { Phase Il IHLW delivered from the interim storage } \\
\text { facility to the shipping cask loading station. }\end{array}$ & 4.2 .4 .1 .3 & 4.2 .4 .1 .4 & \\
\hline
\end{tabular}


Table 4-1. Input and Output Descriptions. (13 sheets)

\begin{tabular}{|c|c|c|c|c|}
\hline Input/Output Name & Input/0utput Description & $\begin{array}{l}\text { Output From } \\
\text { Function(s) }\end{array}$ & $\begin{array}{c}\text { Input To } \\
\text { Function (s) }\end{array}$ & $\begin{array}{c}\text { Child of } \\
\text { Input/Output }\end{array}$ \\
\hline Phase II IHLW for storage & $\begin{array}{l}\text { IHLW from the Phase It HLW immobilization } \\
\text { facility, sealed in canisters suitable for interim } \\
\text { on-site storage and eventual emplacement in HLH } \\
\text { geologic repository. At time of transport to the } \\
\text { interim storage facility the waste will be } \\
\text { certified to meet repository acceptance } \\
\text { requirements. }\end{array}$ & & 4.2 .4 .1 .3 & IHLW for storage \\
\hline $\begin{array}{l}\text { Phase II Solidified HLW } \\
\text { and IRU Production } \\
\text { Information }\end{array}$ & $\begin{array}{l}\text { Documentation supplied by the Phase II HLW and TRU } \\
\text { immobilization facility certifying that the } \\
\text { product compl ies with interim storage facility } \\
\text { acceptance specifications. Those specifications } \\
\text { will include WIPP/HLW geologic repository } \\
\text { acceptance criteria, as applicable. }\end{array}$ & & 4.2 .4 .1 .3 & $\begin{array}{l}\text { Solidified HLW and } \\
\text { IRU Production } \\
\text { Information }\end{array}$ \\
\hline $\begin{array}{l}\text { Phase II Solidified KLW } \\
\text { and TRU Storage } \\
\text { Information }\end{array}$ & $\begin{array}{l}\text { Documentation supplied by the Phase II Solidified } \\
\text { HLW interim storage facility certifying that the } \\
\text { Phase II IHLW and ITUU were stored in accordance } \\
\text { with interim storage specifications. }\end{array}$ & 4.2 .4 .1 .3 & & $\begin{array}{l}\text { Sol idified HLW and } \\
\text { TRU Storage } \\
\text { Information }\end{array}$ \\
\hline $\begin{array}{l}\text { Phase II Solidified HLW } \\
\text { and TRU Transport } \\
\text { Mechanism }\end{array}$ & $\begin{array}{l}\text { The ready-to-use cask and vehicle for onsite } \\
\text { transport of immobilized HLW/RU waste from the } \\
\text { Phase II HLH innobilization facility to the } \\
\text { interim storage facility. The transport mechanism } \\
\text { is provided by the Inter im store Solidified HLW } \\
\text { and IRU Waste function (4.2.4.1). }\end{array}$ & $\begin{array}{l}4.2 .4 \\
4.2 .4 .1 \\
4.2 .4 .1 .3\end{array}$ & $\begin{array}{l}4.2 .3 \\
4.2 .3 .5 \\
4.2 .3 .5 .4\end{array}$ & \\
\hline $\begin{array}{l}\text { Prepare Solidified HLW } \\
\text { and TRU for Shipment } \\
\text { Garbage }\end{array}$ & $\begin{array}{l}\text { Ordinary nonradicactive, norhazardous sol id waste } \\
\text { generated within the Prepare sol idified HLW for } \\
\text { shipment function, suitable for disposal in a } \\
\text { sanitary landf } i l l \text {. }\end{array}$ & 4.2 .4 .1 .4 & & $\begin{array}{l}\text { Is Solidified HLW and } \\
\text { TRU Garbage }\end{array}$ \\
\hline $\begin{array}{l}\text { Prepare Solidified HLW } \\
\text { and TRU for Shipment } \\
\text { Hazardous Waste }\end{array}$ & $\begin{array}{l}\text { Solid waste generated within the Prepare } \\
\text { Sol idified HLW for Shipment function that is } \\
\text { classified as hazardous (dangerous) per EPA or } \\
\text { state of Washington regulations. }\end{array}$ & 4.2 .4 .1 .4 & & $\begin{array}{l}\text { IS Solidified HLW and } \\
\text { IRU Haste Hazardous } \\
\text { Haste }\end{array}$ \\
\hline
\end{tabular}


Table 4-1. Input and Output Descriptions. (13 sheets)

\begin{tabular}{|c|c|c|c|c|}
\hline Input/Output Name & Input/Output Description & $\begin{array}{l}\text { Output From } \\
\text { Function }(s)\end{array}$ & $\begin{array}{c}\text { Input To } \\
\text { Function (s) }\end{array}$ & $\begin{array}{c}\text { Child of } \\
\text { Input/Output }\end{array}$ \\
\hline $\begin{array}{l}\text { Prepare Sol idified HLU } \\
\text { and TRU for Shipment } \\
\text { Prepared Sol id Waste }\end{array}$ & $\begin{array}{l}\text { Solid waste, generated from the Prepare Solidified } \\
\text { HLW for Shipment function, that has been } \\
\text { segregated, packaged, assayed, and certified for } \\
\text { transfer to Hanford Si te Function } 4.3 \text {, Remedy } \\
\text { Solid Waste, for further treatment or disposal. } \\
\text { This includes mixed and radioactive wastes. }\end{array}$ & 4.2 .4 .1 .4 & & $\begin{array}{l}\text { IS Sol idified HLW and } \\
\text { TRU Prepared Sol id } \\
\text { Waste }\end{array}$ \\
\hline $\begin{array}{l}\text { Prepare Solidified HLW } \\
\text { and TRU for Shipment } \\
\text { Treated Gaseous Effluents }\end{array}$ & $\begin{array}{l}\text { Treated gaseous waste from functions associated } \\
\text { with the preparation and loading of sol idified HLH } \\
\text { for shipment. Treated gaseous effluents are } \\
\text { discharged to the atmosphere. }\end{array}$ & 4.2 .4 .1 .4 & & $\begin{array}{l}\text { 15 Solidified HLH and } \\
\text { TRU Treated Gaseous } \\
\text { Effluents }\end{array}$ \\
\hline $\begin{array}{l}\text { Prepare Solidified HLH } \\
\text { and TRU for Shipment } \\
\text { Treated Liquid Effluents }\end{array}$ & $\begin{array}{l}\text { Liquid effluents which meet interface acceptance } \\
\text { criteria for discharge directly to the } 200 \text { Area } \\
\text { Treated Effluent Disposal facility (TEDF). }\end{array}$ & 4.2 .4 .1 .4 & & $\begin{array}{l}\text { IS Sol idified HLW and } \\
\text { IRU Treated Liquid } \\
\text { Effluents }\end{array}$ \\
\hline $\begin{array}{l}\text { Prepare Solidified } \mathrm{HLW} \\
\text { and TRU for Shiprent } \\
\text { Untreated Liquid } \\
\text { Effluents }\end{array}$ & $\begin{array}{l}\text { Generated liquid effluents which require treatment } \\
\text { and meet interface acceptance criteria for } \\
\text { discharge directly to the Liquid Effluent } \\
\text { Retention Facility (LERF) and subsequent treatment } \\
\text { in the Effluent Treatment Facility (ETf). }\end{array}$ & 4.2 .4 .1 .4 & & $\begin{array}{l}\text { IS Sol idified HLW and } \\
\text { TRU Untreated Liquid } \\
\text { Effluents }\end{array}$ \\
\hline $\begin{array}{l}\text { Raw Materials for IS } \\
\text { Dispositioned Cs/Sr } \\
\text { Capsules }\end{array}$ & $\begin{array}{l}\text { Chemicals, containers, util ities, replacenent } \\
\text { equipment, spare parts, suppl ies, etc.. necessary } \\
\text { for the interim storage of dispositioned Cs/Sr } \\
\text { capsules. }\end{array}$ & & 4.2 .4 .1 .1 & $\begin{array}{l}\text { Raw Materials for IS } \\
\text { Sol idified HLW and } \\
\text { TRU }\end{array}$ \\
\hline $\begin{array}{l}\text { Raw Materials for IS } \\
\text { Phase I Solidified HLW }\end{array}$ & $\begin{array}{l}\text { Chemicals, containers, utilities, replacement } \\
\text { equipment, spare parts, suppl ies, etc. necessary } \\
\text { for the interim storage of Phase I sol idified HLW. }\end{array}$ & & $\begin{array}{l}4.2 .4 .1 .2 \\
4.2 .4 .1 .2 .6\end{array}$ & $\begin{array}{l}\text { Raw Materials for Is } \\
\text { Sol idified HLW and } \\
\text { TRU }\end{array}$ \\
\hline $\begin{array}{l}\text { Raw Materials for IS } \\
\text { Phase II Sol idified HLW } \\
\text { and IRU }\end{array}$ & $\begin{array}{l}\text { Chemicals, containers, utilities, replacement } \\
\text { equipment, spare parts, supplies, etc. necessary } \\
\text { for the interim storage of Phase II sol idified } \\
\text { HLH. }\end{array}$ & & 4.2 .4 .1 .3 & $\begin{array}{l}\text { Raw Materials for is } \\
\text { Solidified } H L W \text { and } \\
\text { TRU }\end{array}$ \\
\hline $\begin{array}{l}\text { Raw Materials for IS } \\
\text { Solidified HLW and TRU }\end{array}$ & $\begin{array}{l}\text { Chemicals, containers, utilities, replacement } \\
\text { equipment, spare parts, suppl ies, etc. necessary } \\
\text { for the interim storage of solidified } H L W \text { and TRU } \\
\text { waste. }\end{array}$ & & 6.2 .4 .1 & Raw Materials for DW \\
\hline $\begin{array}{l}\text { Raw Materials for Prepare } \\
\text { Sol idified HLW and TRU } \\
\text { for Shipment }\end{array}$ & $\begin{array}{l}\text { Chemicals, containers, utilities, replacement } \\
\text { equipment, spare parts, supplies, etc. necessary } \\
\text { for the preparation and loading of solidified HLW } \\
\text { for shipment. }\end{array}$ & & 4.2 .4 .1 .4 & $\begin{array}{l}\text { Raw Materials for IS } \\
\text { Sol idified HLW and } \\
\text { TRU }\end{array}$ \\
\hline
\end{tabular}


Table 4-1. Input and Output Descriptions. (13 sheets)

\begin{tabular}{|c|c|c|c|c|}
\hline Input/Output Name & Input/Output Description & $\begin{array}{l}\text { Output From } \\
\text { Function(s) }\end{array}$ & $\begin{array}{c}\text { Input To } \\
\text { Function }(s)\end{array}$ & $\begin{array}{l}\text { Child of } \\
\text { Input/Output }\end{array}$ \\
\hline $\begin{array}{l}\text { Retrieve Phase } 1 \\
\text { Solidified HLW from } \\
\text { Storage SGW }\end{array}$ & $\begin{array}{l}\text { Solid, liquid, and gaseous waste generated by } \\
\text { system operation. }\end{array}$ & 4.2 .4 .1 .2 .4 & 4.2 .4 .1 .2 .6 & \\
\hline Retrieved Cesium Product & $\begin{array}{l}\text { Cesium product that has been retrieved from its } \\
\text { interim storage location and moved to the } \\
\text { transport cask loading location. }\end{array}$ & 4.2 .4 .1 .2 .4 & 4.2 .4 .1 .2 .5 & \\
\hline Retrieved Phase 1 IHLH & $\begin{array}{l}\text { Phase I IHLH that has been retrieved from its } \\
\text { interim storage location and moved to the } \\
\text { transport cask loading location. }\end{array}$ & $4.2 .4 \cdot 1.2 .4$ & 4.2 .4 .1 .2 .5 & \\
\hline $\begin{array}{l}\text { Sol idified HLW and TRU } \\
\text { Production Information }\end{array}$ & $\begin{array}{l}\text { Documentat ion supplied by production facilities } \\
\text { certifying that containers comply with sol idified } \\
\text { HLW and TRU interim storage facility accept ance } \\
\text { specifications. Those specifications will include } \\
\text { WIPP andor HLW geologic repository accept ance } \\
\text { criteria where appl icable. }\end{array}$ & 1 & $\begin{array}{l}4.2 \\
4.2 .4 \\
4.2 .4 .1\end{array}$ & \\
\hline $\begin{array}{l}\text { Solidified HLH and TRU } \\
\text { Recertification } \\
\text { Information }\end{array}$ & $\begin{array}{l}\text { Documentation certifying that the solidified HLH } \\
\text { and TRU waste containers meet the repository } \\
\text { acceptance criteria at the time of loading into } \\
\text { repository shipping casks. }\end{array}$ & $\begin{array}{l}4 \\
4.2 \\
4.2 .4 \\
4.2 .4 .1 \\
4.2 .4 .1 .4\end{array}$ & 1 & - \\
\hline $\begin{array}{l}\text { Transport Phase I } \\
\text { Sol idified HLH to Interim } \\
\text { Storage SGW }\end{array}$ & $\begin{array}{l}\text { Solid, liquid, and gaseous waste generated by } \\
\text { system operation. }\end{array}$ & 4.2 .4 .1 .2 .2 & 4.2 .4 .1 .2 .6 & \\
\hline
\end{tabular}




\subsection{REQUIREMENTS ALLOCATION}

Two types of requirements are allocated to Function 4.2.4.1, Interim Store Solidified $H \mathrm{LW}$ and TRU Waste, and its associated subfunctions, inputs, outputs, and architecture. Constraints are requirements imposed on functions, architecture, and interfaces from agencies external to the TWRS. Performance requirements are developed within TWRS and can be changed as necessary in the course of the systems engineering activity. The text of these requirements is provided in Section 7.0.

An additional type of requirements, termed proof-of-concept requirements, is applicable to Phase 1 of the TWRS privatization effort. Proof-of-concept requirements are applicable only to the inputs to Function 4.2.4.1. They are included in this document to fully define the input characteristics.

\subsection{REQUIREMENTS ALLOCATION TO FUNCTIONS}

Table 5-1 lists the constraints and performance requirements allocated to Function 4.2.4.1 and its subfunctions. There are no proof-of-concept requirements associated with these functions.

\subsection{REQUIREMENTS ALLOCATED TO INPUTS AND OUTPUTS}

Table 5-2 lists the constraints, performance requirements, and proof-ofconcept requirements allocated to the inputs and outputs of Function 4.2.4.1 and its subfunctions. 
Table 5-1. Requirements Allocated to Functions. (13 sheets)

\begin{tabular}{|c|c|c|}
\hline Function & Constraints & Performance Requirements \\
\hline $\begin{array}{l}\text { 4.2.4.1 } \\
\text { interim Store Sol idified HLW and TRU } \\
\text { Haste }\end{array}$ & 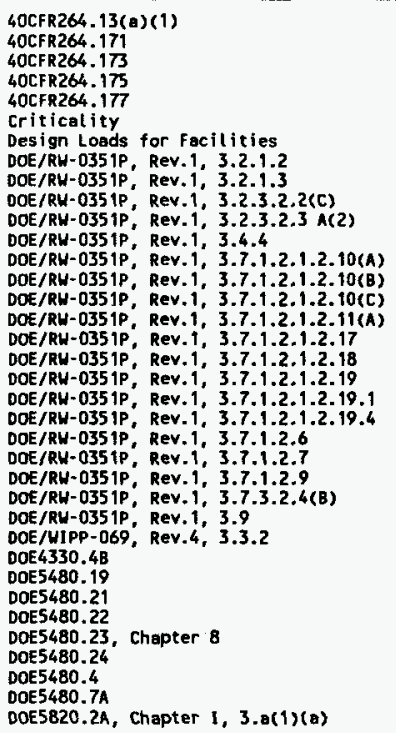 & 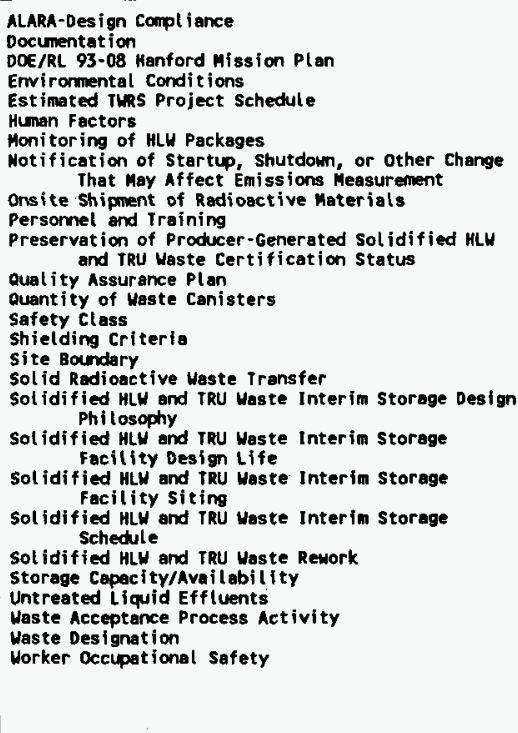 \\
\hline
\end{tabular}


Table 5-1. Requirements Allocated to Functions. (13 sheets)

\begin{tabular}{|c|c|c|}
\hline Function & Constraints & Performance Requirements \\
\hline
\end{tabular}


Table 5-1. Requirements Allocated to Functions. (13 sheets)

\begin{tabular}{|c|c|c|}
\hline Function & Constraints & Performance Requirements \\
\hline & 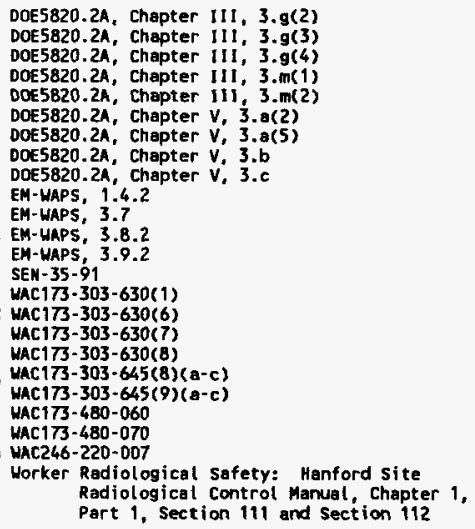 & \\
\hline
\end{tabular}


Table 5-1. Requirements Allocated to Functions. (13 sheets)

\begin{tabular}{|c|c|c|}
\hline Function & Constraints & Performance Requirements \\
\hline
\end{tabular}


Table 5-1. Requirements Allocated to Functions. (13 sheets)

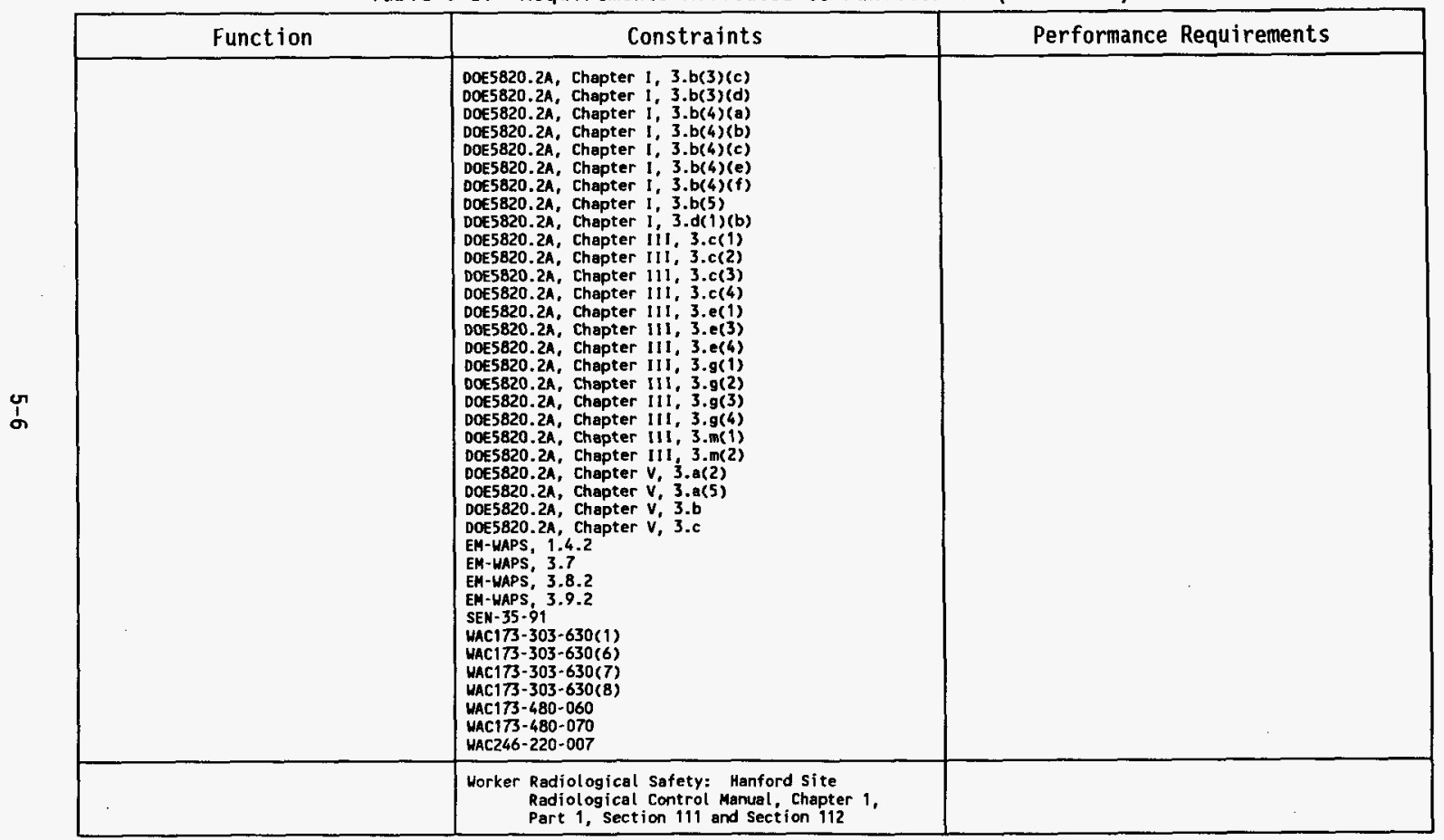


Table 5-1. Requirements Allocated to Functions. (13 sheets)

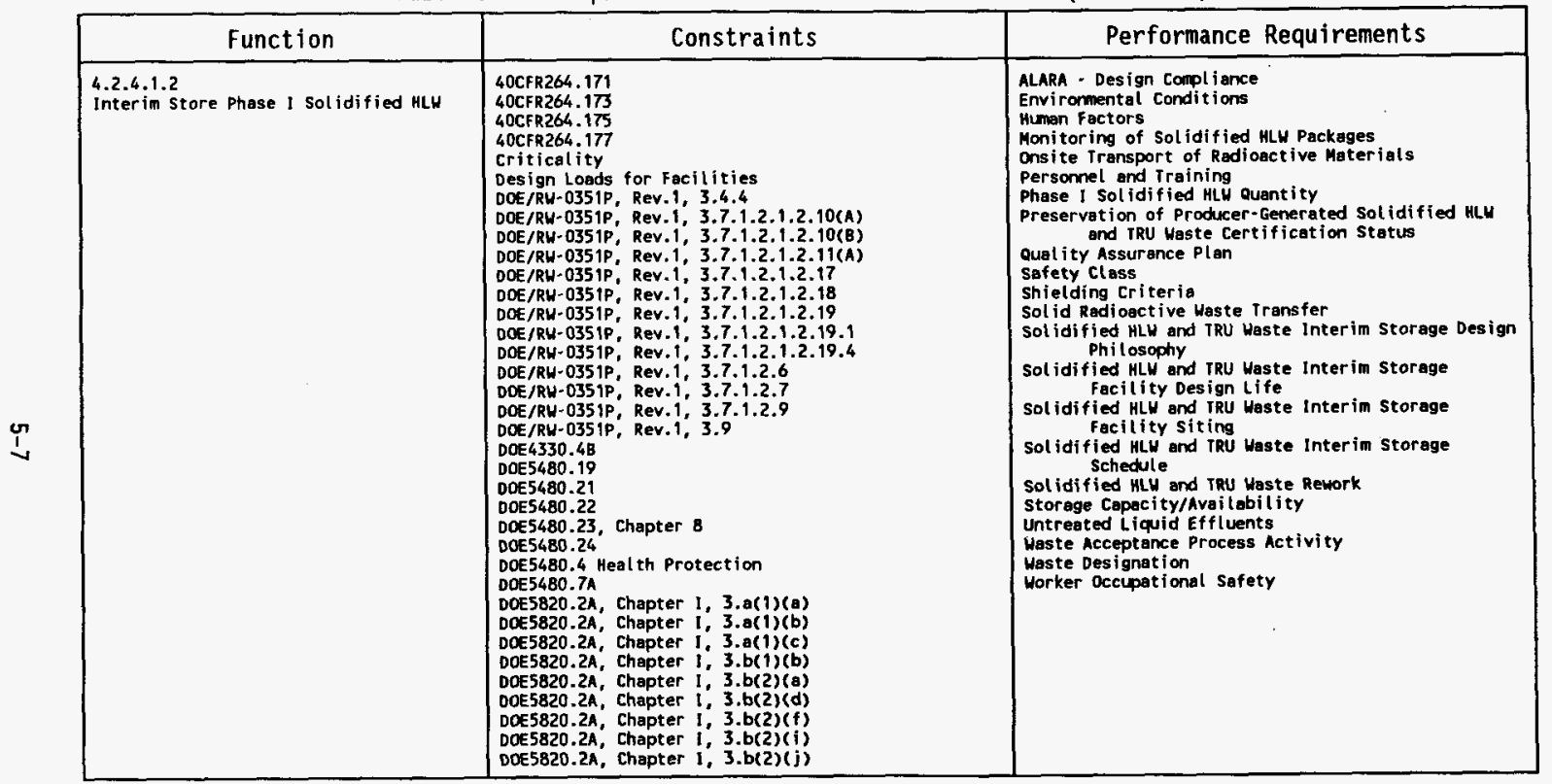


Table 5-1. Requirements Allocated to Functions. (13 sheets)

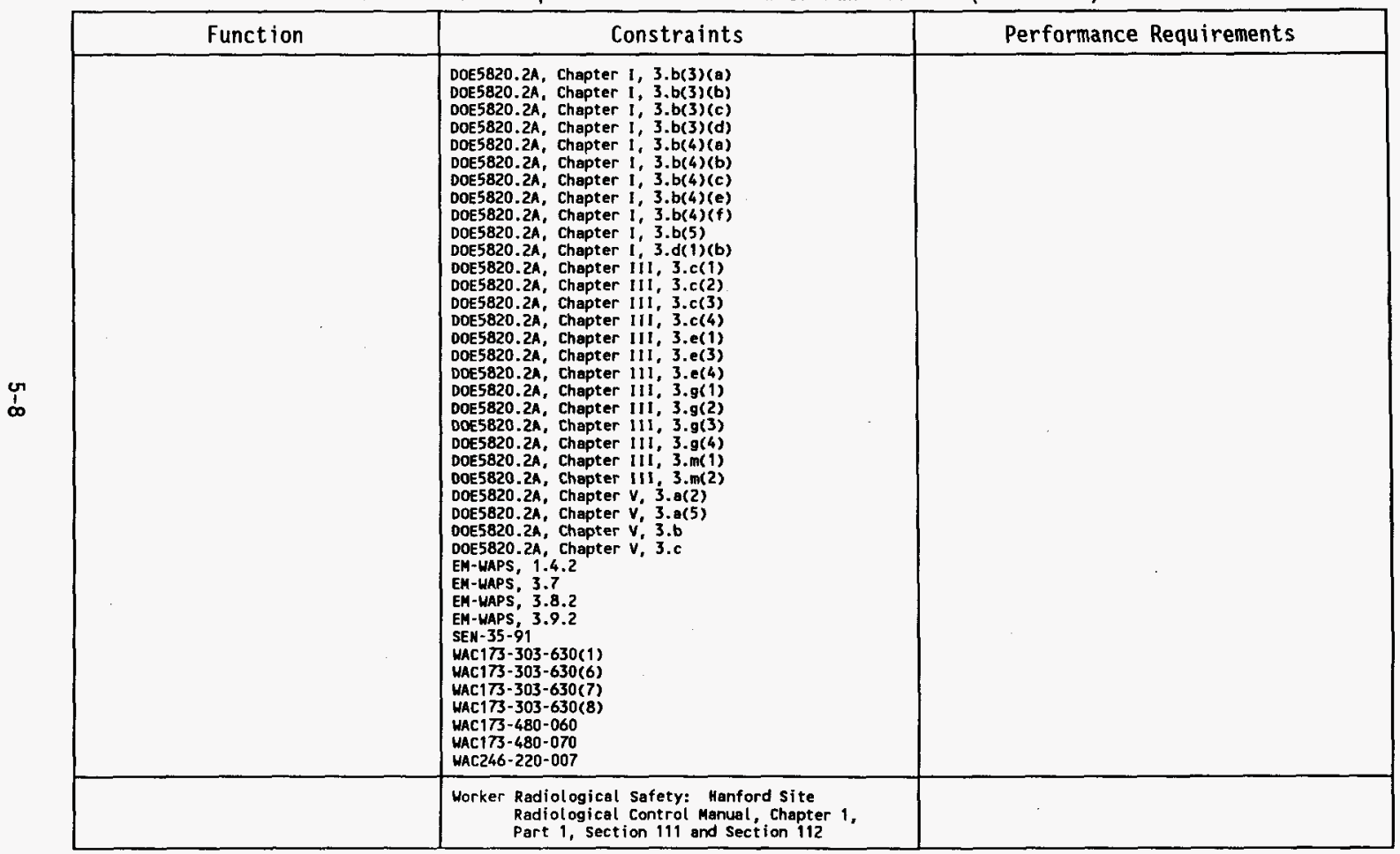


Table 5-1. Requirements Allocated to Functions. (13 sheets)

\begin{tabular}{|c|c|c|}
\hline Function & Constraints & Performance Requirements \\
\hline $\begin{array}{l}4.2 \cdot 4 \cdot 1 \cdot 2.3 \\
\text { Isolate Phase I Solidified HLH }\end{array}$ & $\begin{array}{l}\text { 40CFR264.171 } \\
\text { 40CFR264.173 } \\
\text { 40CFR264.175 } \\
\text { 40CFR264.177 } \\
\text { DOE/RH-0351P, Rev.1, 3.7.1.2.1.2.11(A) } \\
\text { DOE/RH-0351P, Rev.1, 3.7.1.2.1.2.19.4 } \\
\text { DOESB20.2A, Chapter 1, 3.b(3)(a) } \\
\text { DOE5820.2A, Chapter } 1,3 . b(3)(\mathrm{c}) \\
\text { DOES820.2A, chapter } 1,3 . \mathrm{b}(3)(\mathrm{d})\end{array}$ & $\begin{array}{l}\text { Monitoring of Solidified HLW Packages } \\
\text { Sol idified HLL and TRU Waste Rework } \\
\text { Haste Acceptance Process Activity }\end{array}$ \\
\hline $\begin{array}{l}\text { 6.2.4.1.2.4 } \\
\text { Retrieve Phase } 1 \text { Sol idified HLW from } \\
\text { Storage }\end{array}$ & & \\
\hline
\end{tabular}


Table 5-1. Requirements Allocated to Functions. (13 sheets)

\begin{tabular}{|c|c|c|}
\hline Function & Constraints & Performance Requirements \\
\hline $\begin{array}{l}\text { 4.2.4.1.3 } \\
\text { Interim Store Phase II Solidified HLW }\end{array}$ & 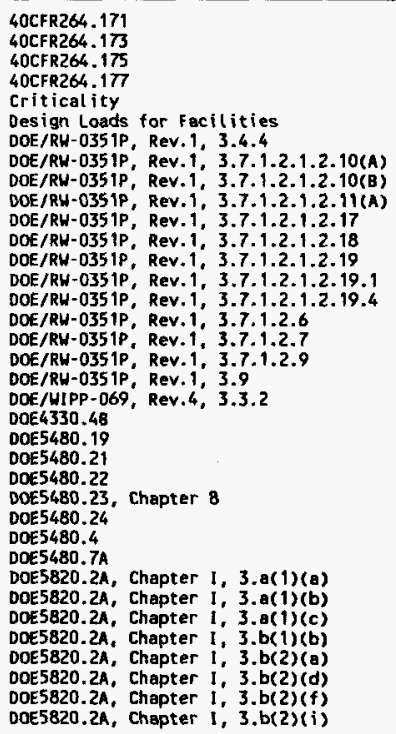 & 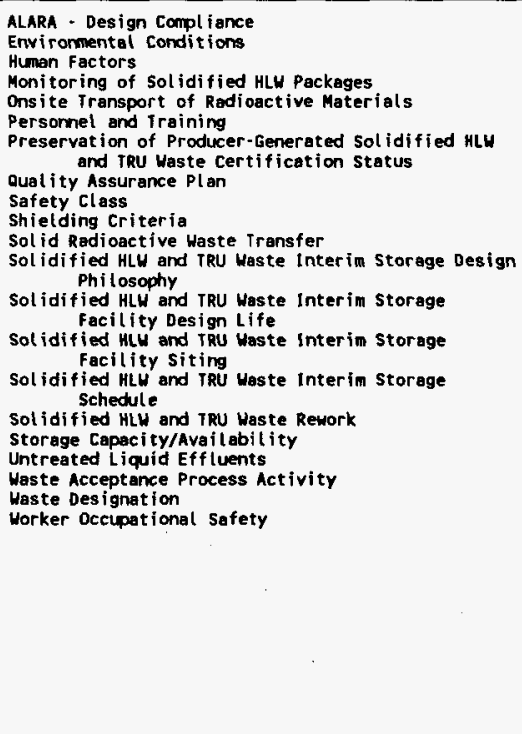 \\
\hline
\end{tabular}


Table 5-1. Requirements Allocated to Functions. (13 sheets)

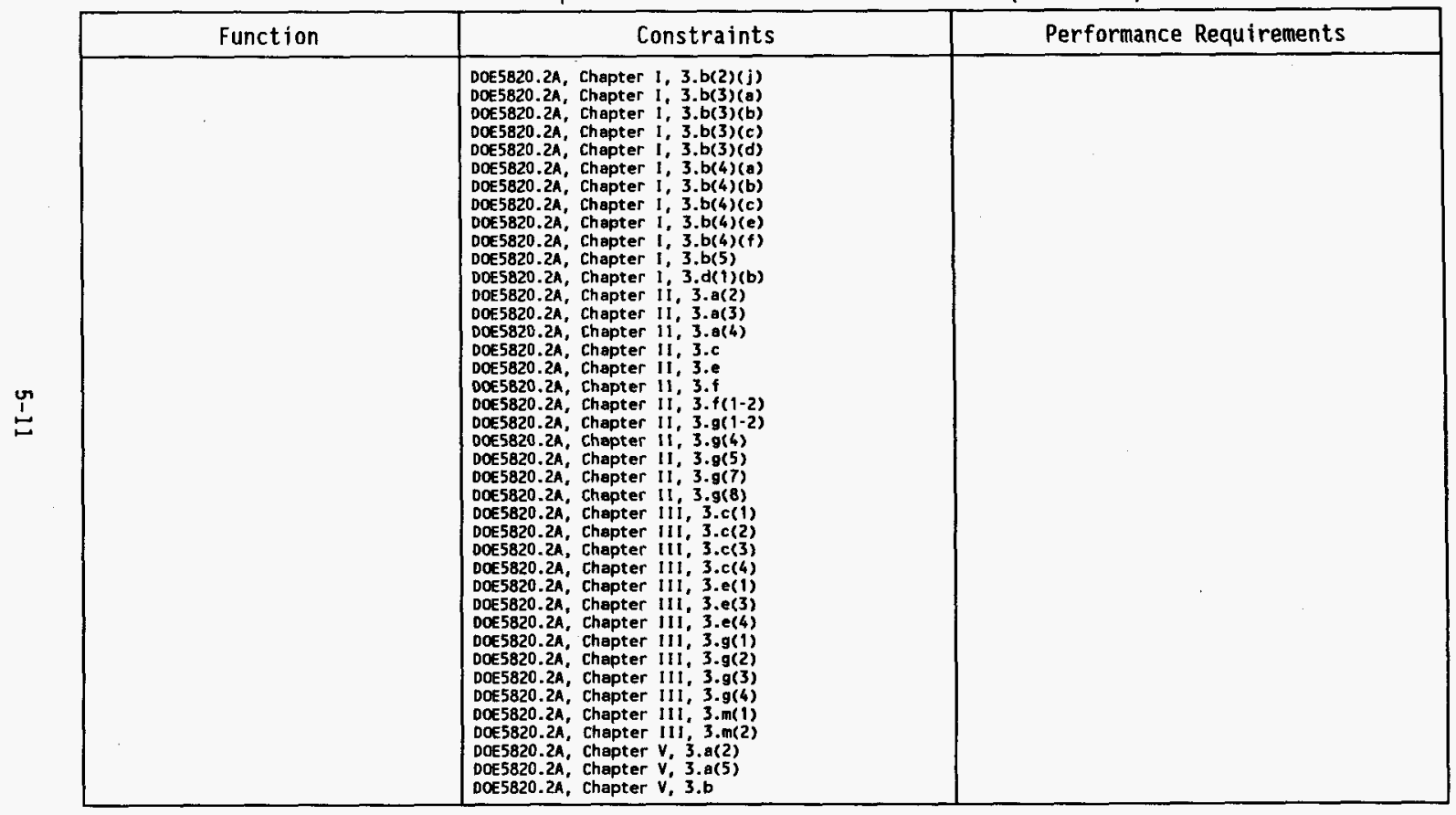


Table 5-1. Requirements Allocated to Functions. (13 sheets)

\begin{tabular}{|c|c|c|}
\hline Function & Constraints & Performance Requirements \\
\hline & 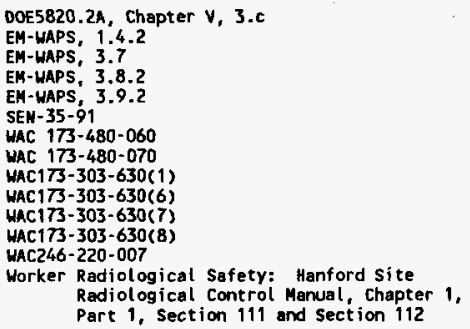 & \\
\hline
\end{tabular}


Table 5-1. Requirements Allocated to Functions. (13 sheets)

\begin{tabular}{|c|c|c|}
\hline Function & Constraints & Performance Requirements \\
\hline
\end{tabular}


Table 5-1. Requirements Allocated to Functions. (13 sheets)

\begin{tabular}{|c|c|c|}
\hline Function & Constraints & Performance Requirements \\
\hline & 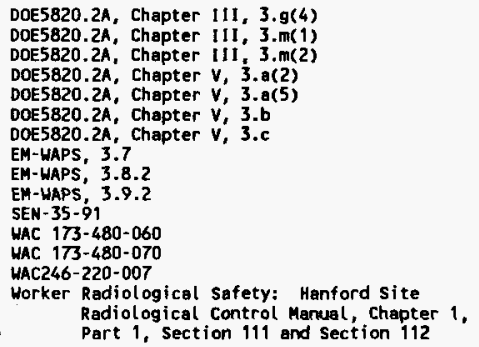 & \\
\hline
\end{tabular}


Table 5-2. Requirements Allocated to Inputs/Outputs. (25 sheets)

\begin{tabular}{|c|c|c|c|}
\hline Input/Output Name & Constraints & Performance Requirements & Proof-of-Concept Regmts \\
\hline $\begin{array}{l}\text { Accept Phase I Sol idified HLW } \\
\text { from Producers SGW }\end{array}$ & & & \\
\hline $\begin{array}{l}\text { Accepted Cesium Product for } \\
\text { Iransport }\end{array}$ & & & \\
\hline $\begin{array}{l}\text { Accepted Phase I IHLU for } \\
\text { Iransport }\end{array}$ & & & \\
\hline $\begin{array}{l}\text { Cesium Product Acceptance } \\
\text { Documentation }\end{array}$ & & & \\
\hline Cesium Product for Processing & & & \\
\hline Cesium Procuct for Retrieval & & & \\
\hline Cesium Product for Storage & & $\begin{array}{l}\text { Cesium Product Storage } \\
\text { Requirements } \\
\text { Fission Product Inter im Storage } \\
\text { HLW Consti ivents Limi tations } \\
\text { Product Verification }\end{array}$ & \\
\hline Cesium Product Isolation Data & & & \\
\hline $\begin{array}{l}\text { Cesium Product Production } \\
\text { Information }\end{array}$ & & & \\
\hline $\begin{array}{l}\text { Cesium Procuct Storage } \\
\text { Informat ion }\end{array}$ & & & \\
\hline $\begin{array}{l}\text { Cesium Prochuct Iransport } \\
\text { Mechanism }\end{array}$ & DOE460.1 & $\begin{array}{l}\text { Onsite shipment of Radioactive } \\
\text { Material }\end{array}$ & \\
\hline $\begin{array}{l}\text { Cesium Product Iransport } \\
\text { Mechanism for Loading }\end{array}$ & DOE 460.1 & $\begin{array}{l}\text { Onsite Shipment of Radioactive } \\
\text { Material }\end{array}$ & \\
\hline $\begin{array}{l}\text { Cesiun Product Transport } \\
\text { Mechanism for Reconditioning }\end{array}$ & DOE 460.1 & $\begin{array}{l}\text { Onsite Shipment of Radioactive } \\
\text { Material }\end{array}$ & \\
\hline $\begin{array}{l}\text { Cesium Product Transport } \\
\text { Mechanism for Reuse }\end{array}$ & DOE 460.1 & $\begin{array}{l}\text { Onsite Shipment of Radioactive } \\
\text { Material }\end{array}$ & \\
\hline
\end{tabular}


Table 5-2. Requirements Allocated to Inputs/Outputs. (25 sheets)

\begin{tabular}{|c|c|c|c|}
\hline Input/Output Name & Constraints & Performance Requirements & Proof-of-Concept Reqmts \\
\hline \multicolumn{4}{|l|}{$\begin{array}{l}\text { Deliver Phase I Solidified HLW } \\
\text { for Shipping or Processing SGN }\end{array}$} \\
\hline \multicolumn{4}{|l|}{$\begin{array}{l}\text { Dispositioned Cs/Sr Capsules for } \\
\text { Disposal }\end{array}$} \\
\hline $\begin{array}{l}\text { Dispositioned Cs/Sr Capsules for } \\
\text { Shipment }\end{array}$ & 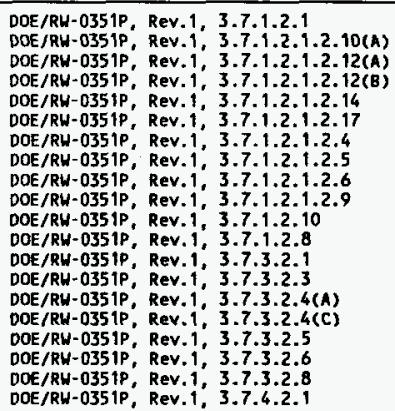 & & \\
\hline
\end{tabular}


Table 5-2. Requirements Allocated to Inputs/Outputs. (25 sheets)

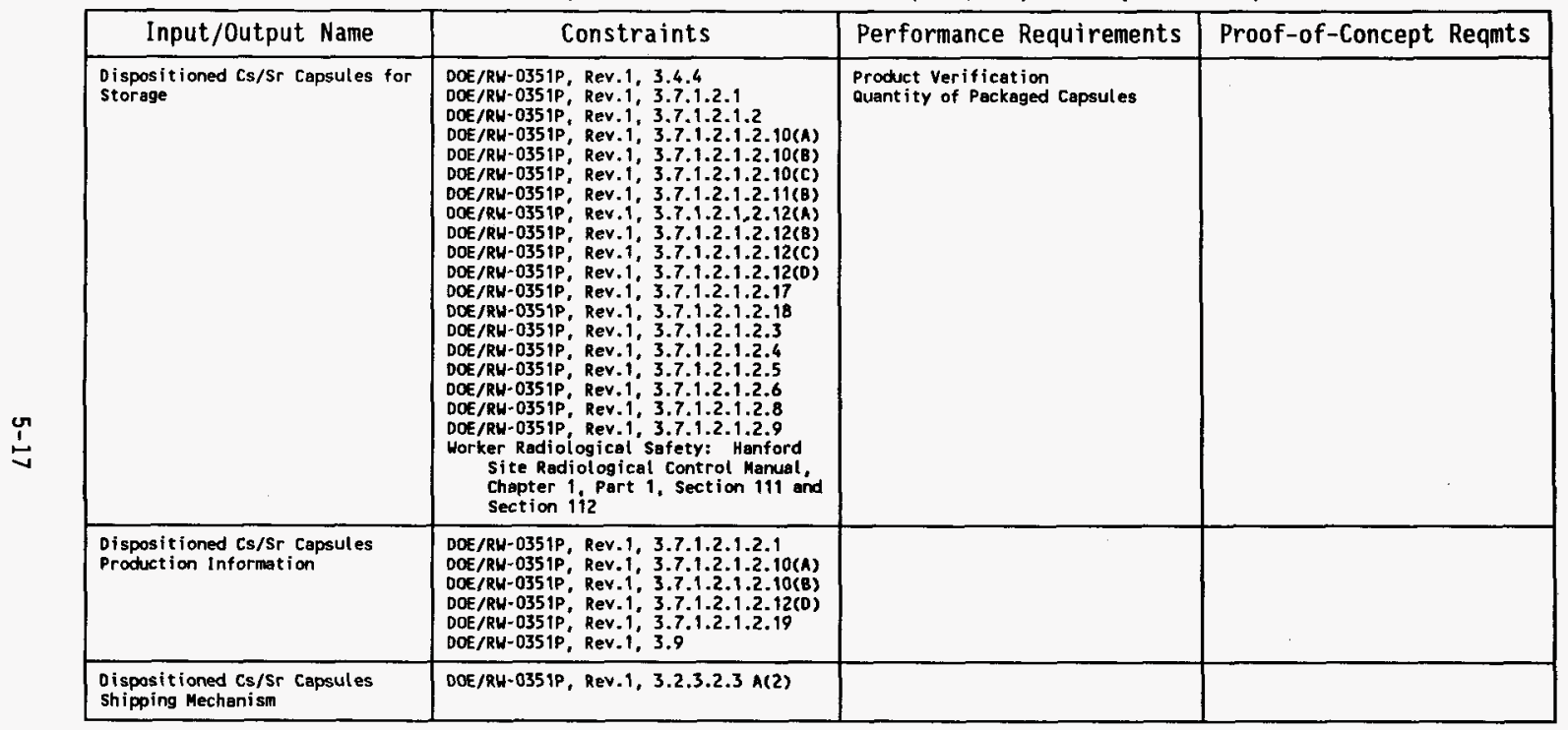


Table 5-2. Requirements Allocated to Inputs/0utputs. (25 sheets)

\begin{tabular}{|c|c|c|c|}
\hline Input/Output Name & Constraints & Performance Requirements & Proof-of-Concept Reqmts \\
\hline $\begin{array}{l}\text { Dispositioned Cs/Sr Capsules } \\
\text { Storage Information }\end{array}$ & 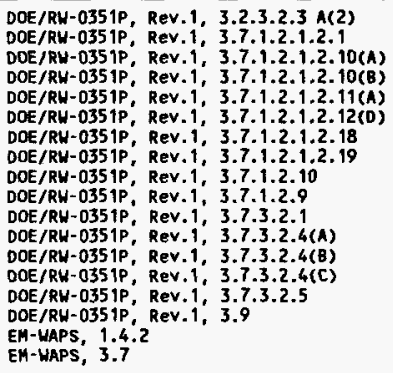 & & \\
\hline $\begin{array}{l}\text { Dispositioned Cs/Sr Capsules } \\
\text { Transport Mechanism }\end{array}$ & DOE 460.1 & $\begin{array}{l}\text { Onsite Shipment of Radioactive } \\
\text { Material }\end{array}$ & \\
\hline
\end{tabular}


Table 5-2. Requirements A1located to Inputs/Outputs. (25 sheets)

\begin{tabular}{|c|c|c|c|}
\hline Input/Output Name & Constraints & Performance Requirements & Proof-of-Concept Reqmts \\
\hline IHLH for Storage & 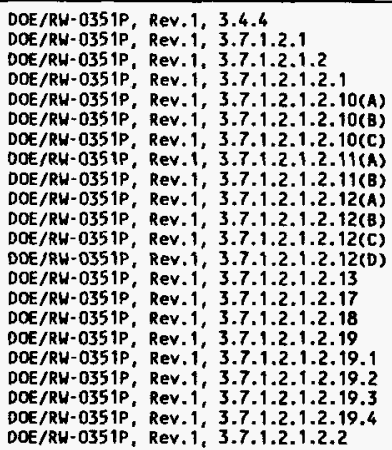 & $\begin{array}{l}\text { HLW Glass Product Rework } \\
\text { HLW Glass Product Variability } \\
\text { HLH Glass Haste Oxide Looding } \\
\text { HLH Vitrification Production } \\
\text { Capacity } \\
\text { Product Verification } \\
\text { Quant ity of IHLW for Storage } \\
\text { quent ity of Haste Canisters } \\
\text { Reporting of Canister Material } \\
\text { Renoved During } \\
\text { Decontamination } \\
\text { Time Tenperature Transformation } \\
\text { Data }\end{array}$ & $\begin{array}{l}\text { Interchangeability } \\
\text { Lift Capability } \\
\text { Hall Thickness } \\
\text { Haste Loading in Glass } \\
\text { Welding }\end{array}$ \\
\hline
\end{tabular}


Table 5-2. Requirements Allocated to Inputs/Outputs. (25 sheets)

\begin{tabular}{|c|c|c|c|}
\hline Input/Output Name & Constraints & Performance Requirements & Proof-of-Concept Reqmts \\
\hline IHLW for Storage (cont inued) & 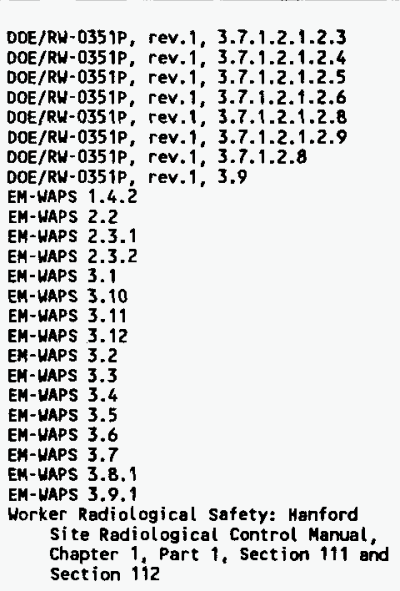 & & . \\
\hline $\begin{array}{l}\text { IHLW Repositary Shipping } \\
\text { Mechanism }\end{array}$ & DOE/RW-0351P, Rev.1, 3.2.3.2.3 A(2) & & \\
\hline $\begin{array}{l}\text { Infrastructure Support for } \mathrm{Clo} \\
\text { Operable Units }\end{array}$ & & & \\
\hline $\begin{array}{l}\text { Infrastructure Support for } \\
\text { D ispose ILLU }\end{array}$ & & & \\
\hline $\begin{array}{l}\text { Infrastructure Support for is } \\
\text { D ispositioned Cs/Sr Capsul es }\end{array}$ & & & \\
\hline $\begin{array}{l}\text { Infrastructure Support for is } \\
\text { Phase I Solidified HLW }\end{array}$ & & & \\
\hline
\end{tabular}


Table 5-2. Requirements Allocated to Inputs/Outputs. (25 sheets)

\begin{tabular}{|c|c|c|c|}
\hline Input/Output Name & Constraints & Performance Requirements & Proof-of-Concept Reqmts \\
\hline $\begin{array}{l}\text { Infrastructure support for is } \\
\text { Phase II Sol idified } H L H \text { and TRU }\end{array}$ & & & \\
\hline $\begin{array}{l}\text { Infrastructure Support for is } \\
\text { Sol idified HLW and TRU }\end{array}$ & & & \\
\hline $\begin{array}{l}\text { Infrastructure Support for } \\
\text { Prepare Sol idified HLW and TRU } \\
\text { for Shipment }\end{array}$ & & & \\
\hline $\begin{array}{l}\text { Is Dispositioned Cs/Sr Capsules } \\
\text { Excess facilities }\end{array}$ & $\begin{array}{l}\text { DOE5820.2A, Chapter v, 3.a } \\
\text { DOE5820.2A, Chapter V, 3.a(2) } \\
\text { DOE5820.2A, Chapter v, 3.a(5) } \\
\text { DOE5820.2A, Chapter V, 3.b } \\
\text { DOE5820.2A, Chapter V, 3.c }\end{array}$ & & \\
\hline $\begin{array}{l}\text { Is Dispositioned Cs/sr Capsules } \\
\text { Garbage }\end{array}$ & & & \\
\hline $\begin{array}{l}\text { Is Dispositioned Cs/Sr Capsules } \\
\text { Hazardous Haste }\end{array}$ & & & \\
\hline $\begin{array}{l}\text { IS Dispositioned Cs/Sr Capsules } \\
\text { Prepared Solid Haste }\end{array}$ & $\begin{array}{l}\text { 40CFR264.13(a)(1) } \\
\text { DOE5820.2A, Chapter III, 3.d }\end{array}$ & Sol id Radioactive Haste Transfer & \\
\hline
\end{tabular}


Table 5-2. Requirements Allocated to Inputs/Outputs. (25 sheets)

\begin{tabular}{|c|c|c|c|}
\hline Input/Output Name & Constraints & Performance Requirements & Proof-of-Concept Reqmts \\
\hline $\begin{array}{l}\text { Is Dispositioned Cs/Sr Capsules } \\
\text { Treated Gaseous Effluents }\end{array}$ & 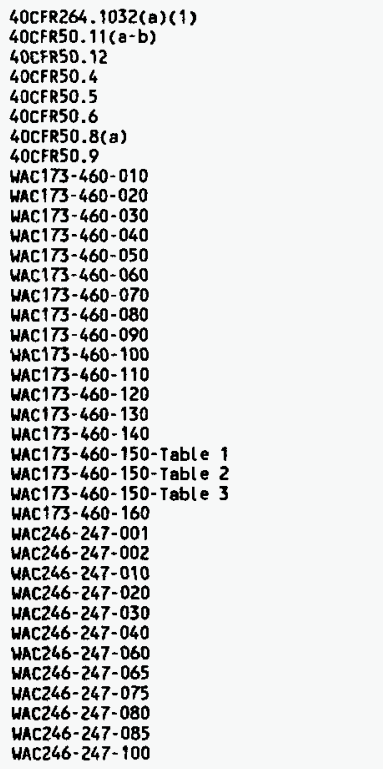 & & . \\
\hline $\begin{array}{l}\text { IS oispositioned } \mathrm{Cs} / \mathrm{Sr} \text { Capsules } \\
\text { Treated Liquid Effluents }\end{array}$ & SWDP Permit 4502 and Fact sheet & $\begin{array}{l}200 \text { Area TEDF Waste Acceptance } \\
\text { Criteria }\end{array}$ & \\
\hline $\begin{array}{l}\text { Is Dispositioned Cs/Sr capsules } \\
\text { Untreated Liquid Effluents }\end{array}$ & $\begin{array}{l}\text { Effluent Treatment facility influent } \\
\text { Restrictions }\end{array}$ & Untreated Liquid Effluents & \\
\hline
\end{tabular}


Table 5-2. Requirements Allocated to Inputs/0utputs. (25 sheets)

\begin{tabular}{|c|c|c|c|}
\hline Input/Output Name & Constraints & Performance Requirements & Proof-of-Concept Reqmts \\
\hline $\begin{array}{l}\text { Is phase I Sol idified HLW Excess } \\
\text { facilities }\end{array}$ & $\begin{array}{l}\text { DOE5820.2A, chapter v, 3.a } \\
\text { DEE5820.2A, Chapter v, } 3 . a(2) \\
\text { DOE5820.2A, chapter v, 3.a(5) } \\
\text { DEE5820.2A, chapter v, } 3 . \mathrm{b} \\
\text { DOE5820.2A, Chapter v, 3.c }\end{array}$ & & \\
\hline $\begin{array}{l}\text { 15 Phase I Sol idified HLW } \\
\text { Garbage }\end{array}$ & & & \\
\hline $\begin{array}{l}\text { Is Phase I Solidified HLW } \\
\text { Hazardous Haste }\end{array}$ & & & \\
\hline $\begin{array}{l}\text { Is Phase I solidified HLW } \\
\text { Prepared Sol id Haste }\end{array}$ & $\begin{array}{l}\text { 40CFR264.13(a)(1) } \\
\text { DOE5B20.2A, Chapter } 11 \mathrm{I} \text {, 3.d }\end{array}$ & Solid Radioactive Maste Transfer & \\
\hline
\end{tabular}

co 
Table 5-2. Requirements Allocated to Inputs/0utputs. (25 sheets)

\begin{tabular}{|c|c|c|c|}
\hline Input/Output Name & Constraints & Performance Requirements & Proof-of-Concept Reqmts \\
\hline $\begin{array}{l}\text { Is Phase I Solidified HLW } \\
\text { Treated Gaseous Effluents }\end{array}$ & 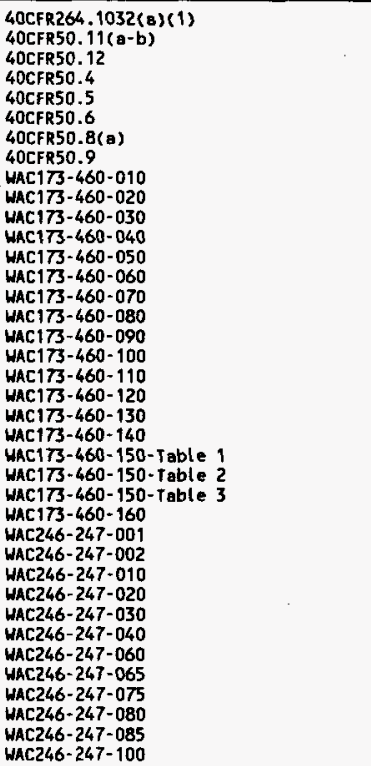 & & $\therefore$ \\
\hline $\begin{array}{l}\text { IS Phase I Solidified HLW } \\
\text { Treated Liquid Effluents }\end{array}$ & SLDP Permit 4502 and fact Sheet & $\begin{array}{l}200 \text { Area TEDF Haste Acceptance } \\
\text { Criteria }\end{array}$ & \\
\hline $\begin{array}{l}\text { Is Phase I Solidified HLW } \\
\text { Untreated Liquid Effluents }\end{array}$ & $\begin{array}{l}\text { Effluent Ireatment facility influent } \\
\text { Restrictions }\end{array}$ & Untreated Liquid Effluents & \\
\hline
\end{tabular}


Table 5-2. Requirements Allocated to Inputs/Outputs. (25 sheets)

\begin{tabular}{|c|c|c|c|}
\hline Input/Output Name & Constraints & Performance Requirements & Proof-of-Concept Reqmts \\
\hline $\begin{array}{l}\text { 1s Phase } 11 \text { Solidified } H L W \text { and } \\
\text { TRU Excess facilities }\end{array}$ & $\begin{array}{l}\text { DOE5820.2A, Chapter v, 3.a } \\
\text { DOE5820.2A, Chapter v, 3.a(2) } \\
\text { DOE5820.2A, chapter v, 3.a(5) } \\
\text { DOE5820.2A, chapter v, 3.b } \\
\text { DOE5820.2A, Chapter V, 3.c }\end{array}$ & & . \\
\hline \multicolumn{4}{|l|}{$\begin{array}{l}\text { Is Phase } 11 \text { Sol idified HLW and } \\
\text { TRU Garbage }\end{array}$} \\
\hline \multicolumn{4}{|l|}{$\begin{array}{l}\text { Is Phase II Sol idified HLW and } \\
\text { TRU Hazardous Waste }\end{array}$} \\
\hline $\begin{array}{l}\text { Is Phase } 11 \text { Solidified } H L W \text { and } \\
\text { TRU Prepared Sol id Haste }\end{array}$ & $\begin{array}{l}\text { 40CFR264.13(a)(1) } \\
\text { DOE5B20.2A, Chapter } 111,3 . d\end{array}$ & Sol id Radioactive Waste Iransfer & \\
\hline
\end{tabular}

ư 
Table 5-2. Requirements Allocated to Inputs/Outputs. (25 sheets)

\begin{tabular}{|c|c|c|c|}
\hline Input/Output Name & Constraints & Performance Requirements & Proof-of-Concept Reqmts \\
\hline $\begin{array}{l}\text { Is Phase II Solidified HLW and } \\
\text { IRU Treated Gaseous Effluents }\end{array}$ & 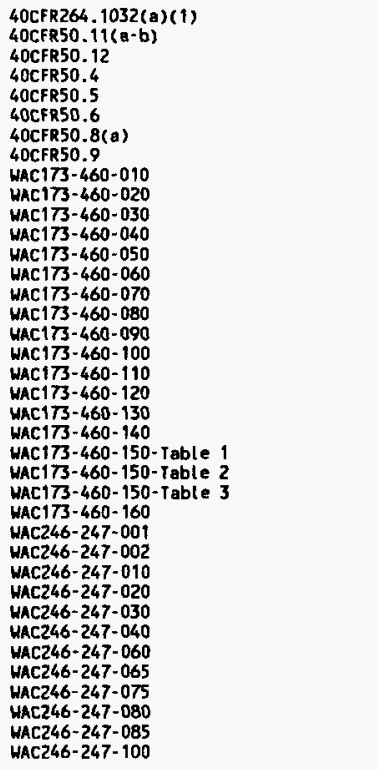 & & \\
\hline $\begin{array}{l}\text { Is Phase II Solidified HLW and } \\
\text { TRU Treated Liquid Effluents }\end{array}$ & SWDP Permit 4502 and Fact sheet & $\begin{array}{l}200 \text { Area TEDF Waste Acceptance } \\
\text { Criteria }\end{array}$ & \\
\hline $\begin{array}{l}\text { IS Phase II Solidified HLW and } \\
\text { IRU Untreated Liquid Effluents }\end{array}$ & $\begin{array}{l}\text { Effluent Treatment facility influent } \\
\text { Restrictions }\end{array}$ & Untreated Liquid Effluents & \\
\hline
\end{tabular}


Table 5-2. Requirements Allocated to Inputs/0utputs. (25 sheets)

\begin{tabular}{|c|c|c|c|}
\hline Input/Output Name & Constraints & Performance Requirements & Proof-of-Concept Reqmts \\
\hline $\begin{array}{l}\text { Is Solidified HLW and TRU Excess } \\
\text { Facilities }\end{array}$ & $\begin{array}{l}\text { DOE5820.2A, Chapter } v, 3 . a \\
\text { DOE5820.2A, Chapter V, 3.a(2) } \\
\text { DOE5820.2A, Chapter V, 3.a(5) } \\
\text { DOE5820.2A, Chapter v, 3.b } \\
\text { DOE5820.2A, Chapter V, 3.c }\end{array}$ & & \\
\hline \multicolumn{4}{|l|}{$\begin{array}{l}\text { Is Solidified HLH and TRU } \\
\text { Garbage }\end{array}$} \\
\hline \multicolumn{4}{|l|}{$\begin{array}{l}\text { IS Solidified HLH and TRU } \\
\text { Hazardous Waste }\end{array}$} \\
\hline $\begin{array}{l}\text { IS Solidified HLW and TRU } \\
\text { Prepared Solid Waste }\end{array}$ & $\begin{array}{l}\text { 4OCFR264.13(a)(1) } \\
\text { DOES820.2A, Chapter } 111,3 . d\end{array}$ & Solid Radioact ive Maste Transfer & \\
\hline
\end{tabular}


Table 5-2. Requirements Allocated to Inputs/0utputs. (25 sheets)

\begin{tabular}{|c|c|c|c|}
\hline Input/Output Name & Constraints & Performance Requirements & Proof-of-Concept Reqmts \\
\hline $\begin{array}{l}\text { Is Sol idified HLL and IRU } \\
\text { Treated Gaseous Effluents }\end{array}$ & 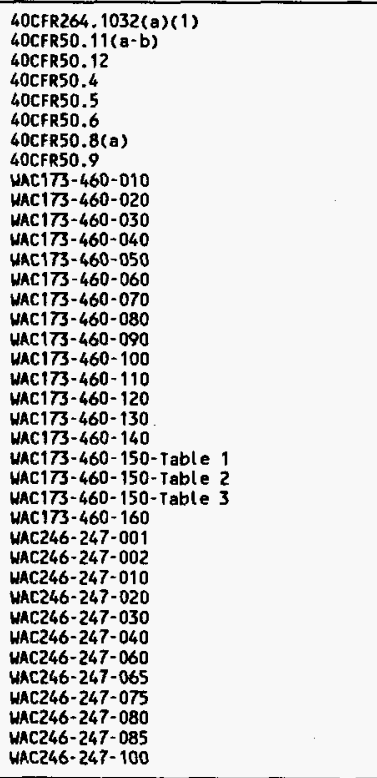 & & . \\
\hline $\begin{array}{l}\text { 1s Sol idified HLW and TRU } \\
\text { Treated Liquid Effluents }\end{array}$ & SWOP Permit 4502 and fact Sheet & $\begin{array}{l}200 \text { Area TEOF Haste Acceptance } \\
\text { Criteria }\end{array}$ & \\
\hline $\begin{array}{l}\text { Is solidified MLW and TRU } \\
\text { Untreated Liquid Effluents }\end{array}$ & $\begin{array}{l}\text { Effluent Treatment facility influent } \\
\text { Restrictions }\end{array}$ & Untreated Liquid Effluents & \\
\hline
\end{tabular}


Table 5-2. Requirements Allocated to Inputs/Outputs. (25 sheets)

\begin{tabular}{|c|c|c|c|}
\hline Input/Output Name & Constraints & Performance Requirements & Proof-of-Concept Reqmts \\
\hline \multicolumn{4}{|l|}{$\begin{array}{l}\text { Isolate Phase I Solidified HLW } \\
\text { SGW }\end{array}$} \\
\hline ITRU for shipment & 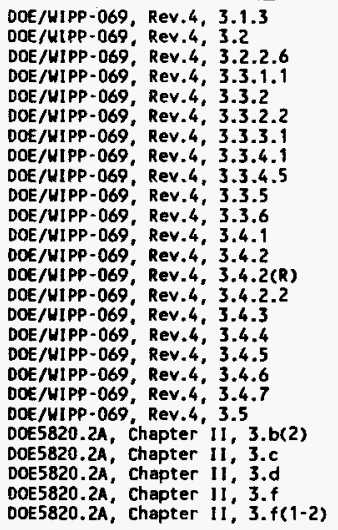 & . & \\
\hline
\end{tabular}


Table 5-2. Requirements Allocated to Inputs/0utputs. (25 sheets)

\begin{tabular}{|c|c|c|c|}
\hline Input/Output Name & Constraints & Performance Requirements & Proof-of-Concept Reqmts \\
\hline ITRU for Storage & 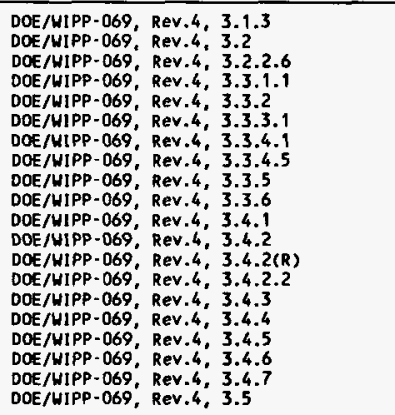 & $\begin{array}{l}\text { Hazardous Haste Determination } \\
\text { Product Verification } \\
\text { Quantity of IIRU Haste for } \\
\text { Storage } \\
\text { Reporting of Canister Material } \\
\text { Removed During } \\
\text { Decontamination } \\
\text { Time Temperature Iransformation } \\
\text { Data } \\
\text { TRU Haste Volume Projection }\end{array}$ & \\
\hline $\begin{array}{l}\text { ITRU Repository Shipping } \\
\text { Mechanism }\end{array}$ & DOE/WIPP-069, ReV.4, 3.2.2.2 & & \\
\hline \multicolumn{4}{|l|}{ Phase 1 IHLH for Isolation } \\
\hline Phase I IHLW for Retrieval & & & \\
\hline
\end{tabular}


Table 5-2. Requirements Allocated to Inputs/0utputs. (25 sheets)

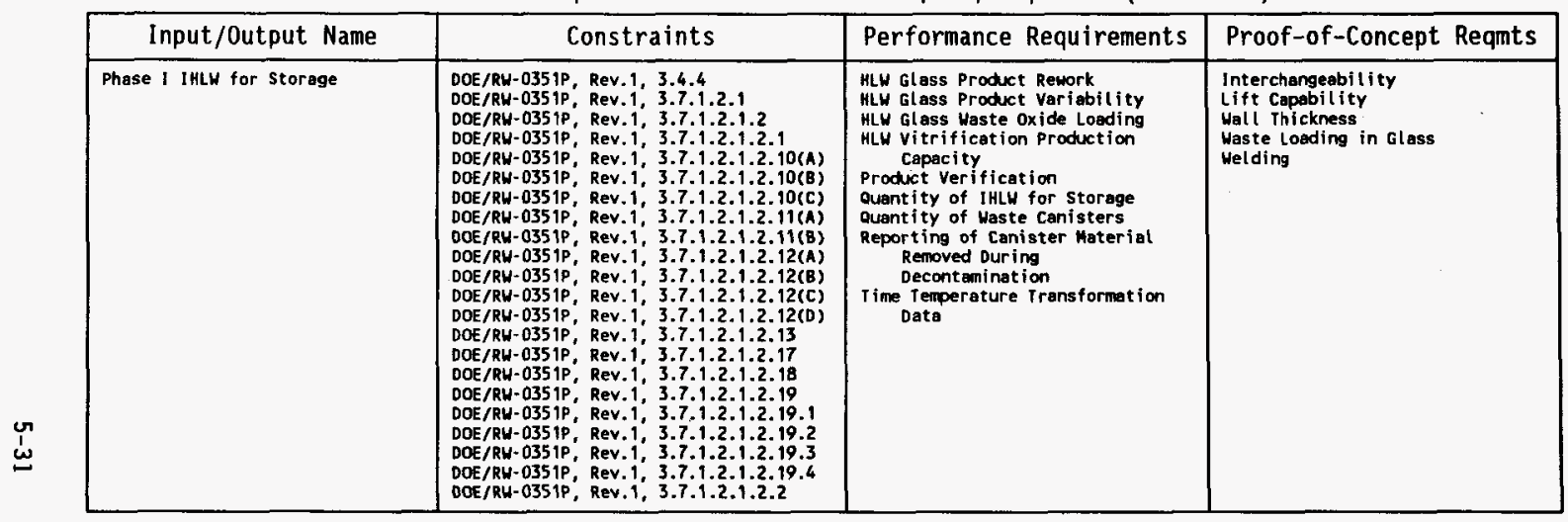


Table 5-2. Requirements Allocated to Inputs/Outputs. (25 sheets)

\begin{tabular}{|c|c|c|c|}
\hline Input/Output Name & Constraints & Performance Requirements & Proof-of-Concept Reqmts \\
\hline $\begin{array}{l}\text { Phase I IHLL for storage } \\
\text { (contimued) }\end{array}$ & 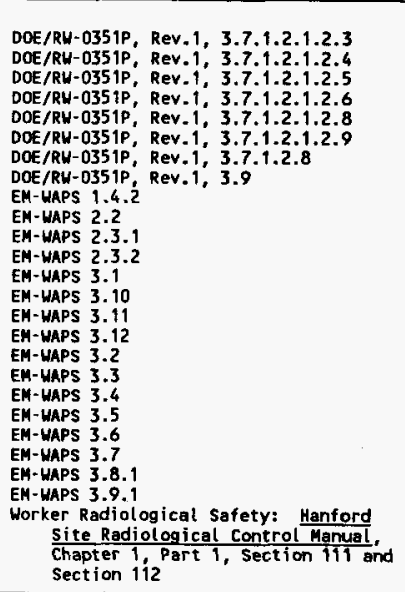 & & \\
\hline Phase I IHLW Isolation Data & 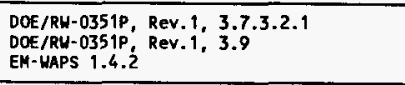 & & \\
\hline $\begin{array}{l}\text { Phase I I HLW Production } \\
\text { Information }\end{array}$ & 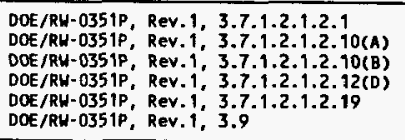 & & \\
\hline
\end{tabular}


Table 5-2. Requirements Allocated to Inputs/Outputs. (25 sheets)

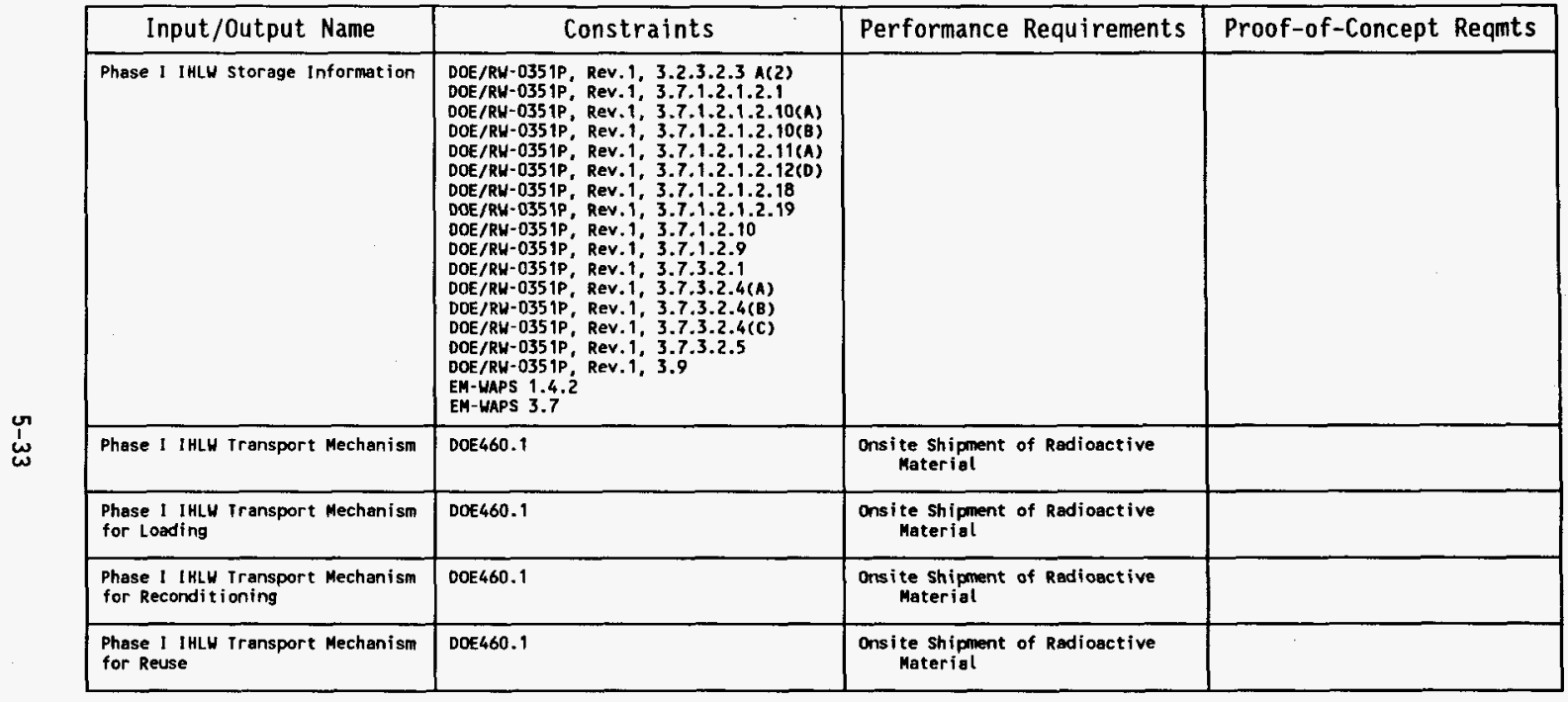


Table 5-2. Requirements Allocated to Inputs/Outputs. (25 sheets)

\begin{tabular}{|c|c|c|c|}
\hline Input/Output Name & Constraints & Performance Requirements & Proof-of-Concept Reqmts \\
\hline Phase $\|$ IHLW for storage & 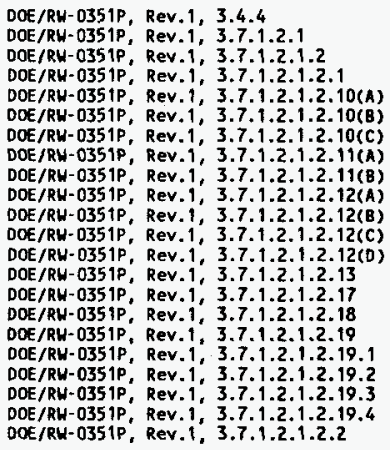 & $\begin{array}{l}\text { HLH Glass Product Rework } \\
\text { HLH Glass Product Varisbility } \\
\text { HLH Glass Haste Oxide Loading } \\
\text { HLW Vitrification Production } \\
\text { Capacity } \\
\text { Product Verification } \\
\text { Quant ity of IHLH for Storage } \\
\text { Quant ity of Waste Canisters } \\
\text { Reporting of Canister Material } \\
\text { Removed During } \\
\text { Decontamination } \\
\text { Time Temperature Transformation } \\
\text { Data }\end{array}$ & \\
\hline
\end{tabular}


Table 5-2. Requirements Allocated to Inputs/Outputs. (25 sheets)

\begin{tabular}{|c|c|c|c|}
\hline Input/Output Name & Constraints & Performance Requirements & Proof-of-Concept Reqmts \\
\hline $\begin{array}{l}\text { Phase II IHLW for storage } \\
\text { (continued) }\end{array}$ & 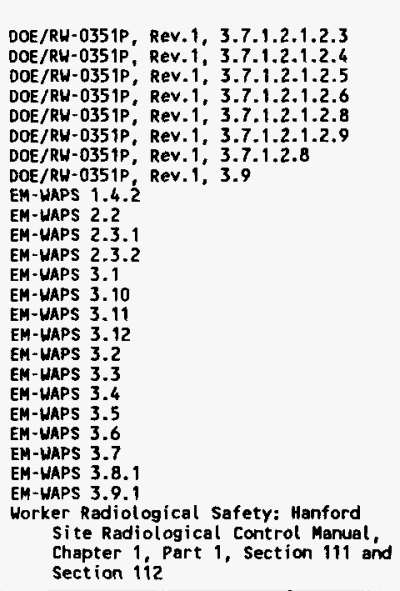 & & \\
\hline $\begin{array}{l}\text { Phase II Sol idified HLH and IRU } \\
\text { for Disposal }\end{array}$ & $\begin{array}{l}\text { DOE/RU-035 IP, Rev.1, 3.7.1.2.1.2.17 } \\
\text { DOE/RH-035 IP, Rev.1, 3.7.1.2.1.2.18 }\end{array}$ & & \\
\hline $\begin{array}{l}\text { Phase II Solidified HLH and TRU } \\
\text { Production Information }\end{array}$ & $\begin{array}{l}\text { DOE/RH-035IP, Rev.1, 3.7.1.2.1.2.1 } \\
\text { DOE/RH-0351P, Rev.1; } 3.7 .1 .2 .1 .2 .10(\mathrm{~A}) \\
\text { DOE/RH-0351P, Rev.1; } 3.1 .1 .2 .1 .10(\mathrm{~B}) \\
\text { DOE/RH-0351P; Rev.1; } 3.7 .1 .2 .1 .2 .12(\mathrm{D}) \\
\text { DOE/RH-0351P, Rev.1; } 3.7 .1 .2 .1 .2 .19 \\
\text { DOE/RH-0351P, Rev.1, 3.9 }\end{array}$ & & \\
\hline
\end{tabular}


Table 5-2. Requirements Allocated to Inputs/0utputs. (25 sheets)

\begin{tabular}{|c|c|c|c|}
\hline Input/Output Name & Constraints & Performance Requirements & Proof-of-Concept Reqmts \\
\hline $\begin{array}{l}\text { Phase II Solidified HLU and TRU } \\
\text { storage Information }\end{array}$ & 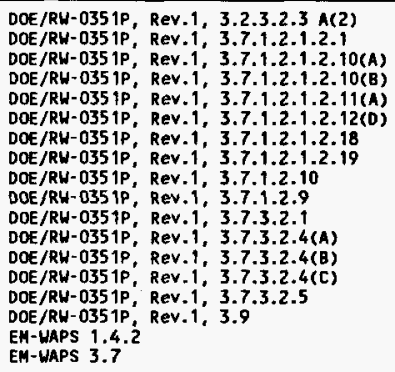 & & \\
\hline $\begin{array}{l}\text { Phase It Solidified HLW and TRU } \\
\text { Iransport Mechanism }\end{array}$ & DOE 460.1 & $\begin{array}{l}\text { Onsite shipment of Radioactive } \\
\text { Material }\end{array}$ & \\
\hline $\begin{array}{l}\text { Prepare Sol idified HLW and TRU } \\
\text { for Shipment Hazardous Waste }\end{array}$ & & & \\
\hline $\begin{array}{l}\text { Prepare Sol idified HLH and TRU } \\
\text { for Shipment Prepared Solid } \\
\text { Waste }\end{array}$ & $\begin{array}{l}\text { 40CFR264.13(a)(1) } \\
\text { DOE5820.2A, Chapter } 111, \text { 3.d }\end{array}$ & Sol id Radioactive Kaste Transfer & \\
\hline
\end{tabular}


Table 5-2. Requirements Allocated to Inputs/0utputs. (25 sheets)

\begin{tabular}{|c|c|c|c|}
\hline Input/Output Name & Constraints & Performance Requirements & Proof-of-Concept Reqmts \\
\hline $\begin{array}{l}\text { Prepare solidified HLW and TRU } \\
\text { for Shipment Ireated Gaseous } \\
\text { Effluents }\end{array}$ & 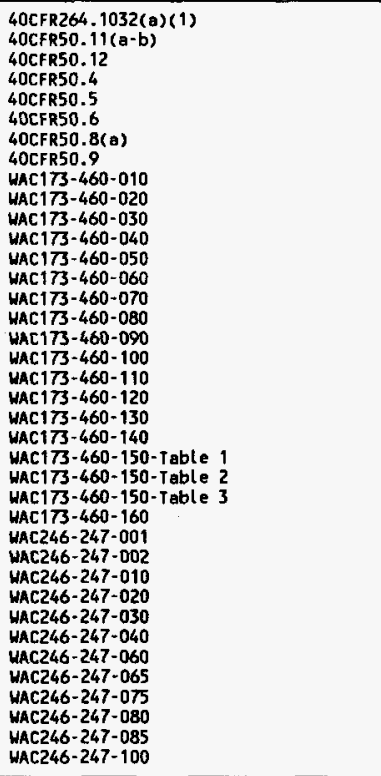 & & . \\
\hline $\begin{array}{l}\text { Prepare Solidified HLW and TRU } \\
\text { for Shipment Ireated Liquid } \\
\text { Effluents }\end{array}$ & SWDP Permit 4502 and fact Sheet & $\begin{array}{l}200 \text { Area TEDF Haste Acceptance } \\
\text { Criteria }\end{array}$ & \\
\hline $\begin{array}{l}\text { Prepare Solidified HLW and TRU } \\
\text { for Shipment Untreated Liquid } \\
\text { Effluents }\end{array}$ & $\begin{array}{l}\text { Effluent Treatment facility influent } \\
\text { Restrictions }\end{array}$ & Untreated Liquid Effluents & \\
\hline
\end{tabular}


Table 5-2. Requirements Allocated to Inputs/0utputs. (25 sheets)

\begin{tabular}{|c|c|c|c|}
\hline Input/Output Name & Constraints & Performance Requirements & Proof-of-Concept Reqmts \\
\hline \multicolumn{4}{|l|}{ Raw Materials for DW } \\
\hline \multicolumn{4}{|l|}{$\begin{array}{l}\text { Raw Materials for Is } \\
\text { Dispositioned Cs/Sr Capsules }\end{array}$} \\
\hline \multicolumn{4}{|l|}{$\begin{array}{l}\text { Raw Materials for IS Phase I } \\
\text { Solidified HLW }\end{array}$} \\
\hline \multicolumn{4}{|l|}{$\begin{array}{l}\text { Raw Materials for Is Phase II } \\
\text { Sol idified HLW and TRU }\end{array}$} \\
\hline \multicolumn{4}{|l|}{$\begin{array}{l}\text { Raw Materials for Prepare } \\
\text { Sol idified HLW and TRU for } \\
\text { Shipment }\end{array}$} \\
\hline \multicolumn{4}{|l|}{$\begin{array}{l}\text { Retrieve Phase I Solidified HLW } \\
\text { from Storage SGW }\end{array}$} \\
\hline \multicolumn{4}{|l|}{ Retrieved Cesium Product } \\
\hline \multicolumn{4}{|l|}{ Retrieved Phase I IHLW } \\
\hline $\begin{array}{l}\text { Solidified HLW and TRU } \\
\text { Recertification information }\end{array}$ & $\begin{array}{l}\text { DOE/RU-0351P, Rev.1, 3.7.1.2.1.2.10(A) } \\
\text { DOE/RH-0351P, Rev.1; 3.7.1.2.1.2.18 } \\
\text { DOE/RH-0351P, Rev.1, 3.7.3.2.1 } \\
\text { DOE/RH-0351P, Rev.1; } 3.7 .3 .2 .5 \\
\text { DOE/RH-0351P, Rev.1, } 3.9 \\
\text { EM-HAS } 1.4 .2 \\
\text { EM-HAPS } 3.7\end{array}$ & & \\
\hline
\end{tabular}


Table 5-2. Requirements Allocated to Inputs/Outputs. (25 sheets)

\begin{tabular}{|c|c|c|c|}
\hline Input/Output Name & Constraints & Performance Requirements & Proof-of-Concept Reqmts \\
\hline $\begin{array}{l}\text { Solidified HLW and TRU Storage } \\
\text { Information }\end{array}$ & 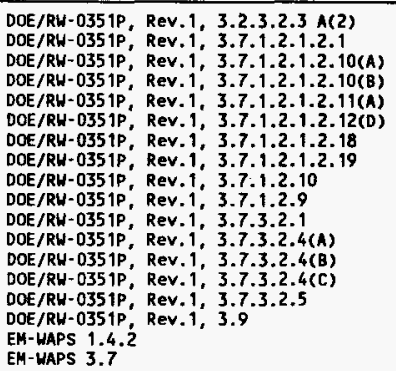 & & \\
\hline $\begin{array}{l}\text { Transport Phase I solidified HLW } \\
\text { to Interim Storage SGW }\end{array}$ & & & \\
\hline
\end{tabular}


WHC-SD-WM-FRD-027 Rev. 0

This page intentionally left blank. 


\subsection{ARCHITECTURE}

This section identifies the architecture selected for the Solidified HLW and TRU Waste Interim Storage System, describes the alternatives considered in selecting the architecture, and identifies further analyses needed to select the next level of architecture. This section also includes the list of requirements satisfied by the selected architecture.

\section{I ARCHITECTURE IDENTIFICATION NUMBER: TO BE DETERMINED}

\subsection{ARCHITECTURE TITLE: SOLIDIFIED HLW AND TRU WASTE INTERIM STORAGE SYSTEM}

\subsection{ARCHITECTURE DEFINITION (PHASE I AND PHASE II)}

Architecture includes facilities and equipment necessary for temporary onsite storage of solidified HLW and TRU waste (sealed immobilized high-level waste [IHLW] canisters, immobilized transuranic (ITRU) waste canisters, Cs

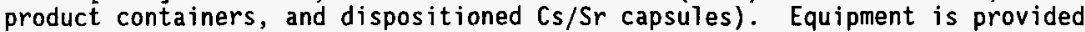
for receiving solidified waste and for transporting it to the interim storage facilities. The facilities will provide features to cool solidified waste, monitor interim storage containment integrity, and load solidified waste into casks for shipment offsite or to an onsite treatment facility for further processing. The DOE-OCRWM will collect the loaded shipping casks and transport them offsite to the repository. Also included in this definition is the equipment to treat/prepare liquid and gaseous effluents, solid wastes, recyclable/reusable materials, and excess facilities to meet acceptance criteria of site dispositioning functions. Gaseous effluents will be treated to meet atmospheric release criteria.

\subsection{ALTERNATIVES CONSIDERED}

Inherent to the selection of an acceptable alternative is evaluation of two strategic items: the type of IHLW/ITRU interim storage facility, and the physical parameters of the IHLW/ITRU containers. The selection of the immobilize HLW/TRU waste container exerts a strong influence on the design of the interim storage facility configuration. The enabling assumptions adopted relative to container parameters are identified in Section 6.6. Based on these enabling assumptions, potential architectures for the container facility are encompassed by the following options.

- Enclosed Building Facility--Use an enclosed facility to provide weather protection, containment and shielding for the solidified HLW and TRU waste in unshielded canisters or canisters in overpacks.

- Pad Storage Facilities--Use exposed storage (e.g., pads compliant with the Resource Conservation and Recovery Act of 1976 [RCRA]) for interim storage of solidified $\mathrm{HLW}$ and TRU waste canisters contained in large $\left(10-m^{3}\right)$ overpack containers located within concrete vaults. 
WHC-SD-WM-FRD-027 Rev. 0

- Bore Hole Facility--Use covered bore holes (or dry wells) for interim storage of solidified HLW and TRU waste in canisters or overpacked canisters.

\subsection{RATIONALE FOR SELECTION}

An enclosed facility was selected for interim storage of Phase 1 solidified HLW (Calmus 1995). No decision has been made on a facility configuration for interim storage of Phase II solidified waste or

dispositioned Cs/Sr capsules. The basis for this decision includes the following:

- TWRS optimization

- Lifecycle safety/cost benefit

- Risk (technical/funding/schedule/political).

\subsection{ENABLING ASSUMPTIONS}

The enabling assumptions are as follows.

1. It is assumed that only dry waste forms would be stored by the Solidified HLW and TRU Waste Interim Storage 5ystem. These forms include IHLW and ITRU canisters, dry Cs in sealed containers, and dispositioned Cs/Sr capsules.

2. It is assumed that vitrified HLW produced during Phase I would be contained in $0.61 \mathrm{~m}$ diameter by $3.00 \mathrm{~m}$ long stainless steel canisters (standard canisters). Phase I interim storage would be required for 1,190 standard canisters (1,137 standard canisters containing IHLW and 53 standard canisters containing secondary HLW).

3. It is assumed that vitrified HLW produced during Phase II would be contained in $0.61 \mathrm{~m}$ diameter by $4.50 \mathrm{~m}$ long stainless steel canisters (large canisters). Phase II interim storage would be required for 7,592 to 21,726 large canisters containing IHLW and ITRU, with the flexibility to store up to 36,444 standard canisters.

4. It is assumed that solid CS product separated from the LLW stream by the Pretreat Supernatant process would be packaged in $0.33 \mathrm{~m}$ diameter by $1.37 \mathrm{~m}$ long stainless steel containers. Required Phase I interim storage capacity ranges from 53 Cs containers (at a heat loading of $1.5 \mathrm{~kW}$ per container) to $158 \mathrm{Cs}$ containers (at $0.5 \mathrm{~kW}$ per container). It is further assumed that any solid Cs produced during Phase II would be transferred directly from the Phase II separation process to the Phase II HLW immobilization process, without requiring interim storage.

5. It is assumed that dispositioned $C s / S r$ capsules would not require interim storage until the Phase II time period (i.e., no Phase I interim storage capacity is required for this material). It is assumed that for Phase II, it will be technically feasible and economically desirable to combine the interim storage of dispositioned $\mathrm{Cs} / \mathrm{Sr}$ capsules with the interim storage of IHLW/ITRU in the same facility. 
6. It is assumed that one or more of the waste forms requiring interim storage would be a mixed waste (containing dangerous components and radioactive components). Therefore, regulations promulgated under RCRA would be applicable to the solidified HLW interim storage facility(ies).

7. It is assumed that systems, components, and structures required solely for the repository interface (staging and loadout) are allocated to the Phase II solidified $\mathrm{HLW}$ and TRU waste interim storage facility. Therefore, functions related to offsite shipment to the repository will not be included in the Phase I solidified HLW interim storage facility.

\subsection{REQUIRED ANALYSES}

The required analyses are as follows.

1. Evaluate the results of the TWRS privatization Phase I bidding process, and later, of the Phase II bidding process, to obtain more information about the waste forms that will require interim storage during each phase.

2. Confirm the technical feasibility and economic benefit of combining the interim storage of dispositioned Cs/Sr capsules with the interim storage of Phase II IHLW/ITRU in the same facility.

3. Perform a trade study to determine which type of facility (enclosed facility, open facility, or bore holes) is the optimum interim storage facility configuration for Phase II solidified HLW and TRU waste.

\subsection{REQUIREMENTS SATISFIED}

\subsubsection{Performance Requirements}

The performance requirements are as follows:

- Storage Capacity/Availability

- Solidified HLW and TRU Waste Interim Storage Design Philosophy

- Solidified HLW and TRU Waste Interim Storage Facility Design Life

- Solidified HLW and TRU Waste Interim Storage Facility Siting

- Solidified HLW and TRU Waste Interim Storage Schedule.

\subsubsection{Constraints}

The constraints are as follows:

- 40CFR191.03(a)

- 40CFR264.1032

- 40CFR264.1033(a)

- 40CFR264.1033(b)

- 40CFR264.1033(c)

- 40CFR264.1033(g)

- 40CFR264.1033(h) 
- 40CFR264.1033(k)

- 40CFR264.1033(1)

- 40CFR264.1054

- 40CFR264.171

- 40CFR264.173

- 40CFR264.175

- 40CFR264.177

- DOE/RW-0351P, Rev. 1, 3.2.1.3

- DOE/RW-0351P, Rev. 1, 3.2.3.2.2(c)

- DOE/RW-035lP, Rev. 1, 3.2.3.2.3 A(2)

- DOE5820.2A, Chapter II, 3.f(1-2)

- DOE5820.2A, Chapter III, 3.I(6)

- EM-WAPS 3.7

- EM-WAPS 3.8 .2

- EM-WAPS 3.9 .2

- WAC173-303-630(1)

- WAC173-303-630(6)

- WAC173-303-630(7)

- WAC246-247-001

- WAC246-247-002

- WAC246-247-010

- WAC246-247-020

- WAC246-247-030

- WAC246-247-040

- WAC246-247-060

- WAC246-247-065

- WAC246-247-075

- WAC246-247-080

- WAC246-247-085

- WAC246-247-100. 


\subsection{REQUIREMENTS DEFINITION}

This section provides the descriptions of the requirements, referenced in Sections 5.0 and 6.0, that are satisfied by the architecture addressed in this document. Table 7-1 defines the constraints, Table 7-2 defines the performance requirements, and Table 7-3 defines the proof-of-concept requirements allocated to the functions, inputs, and outputs. 
Table 7-1. Constraint Definitions. (100 sheets)

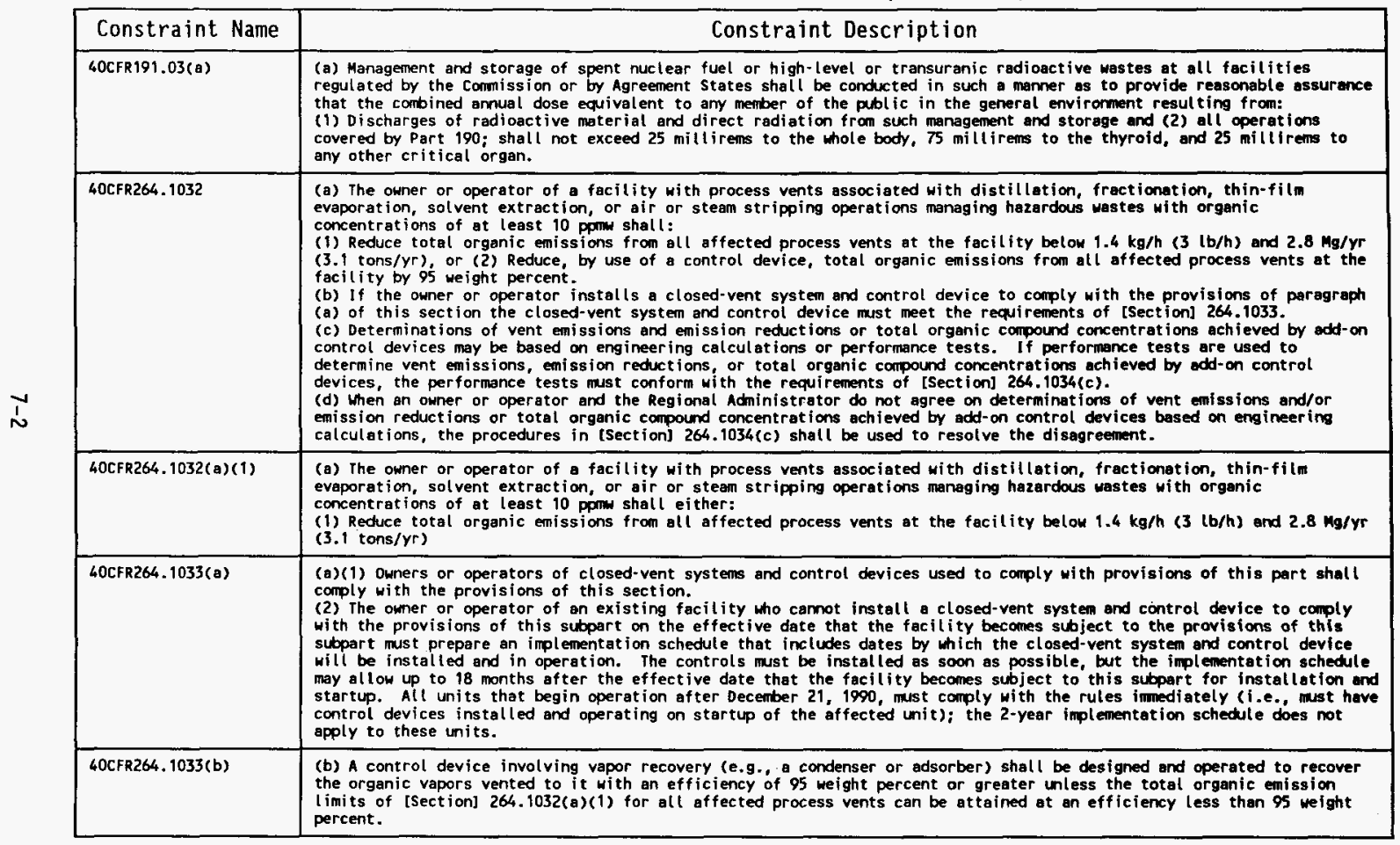


no!joas $s ! 47$ to (q) pue (e) sydej6ejed

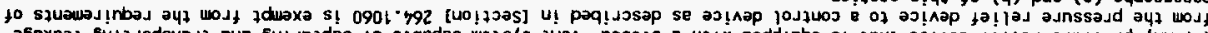

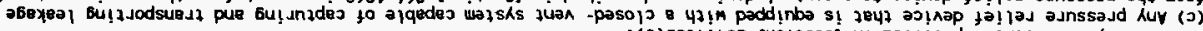

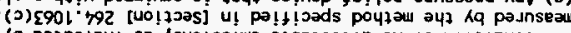

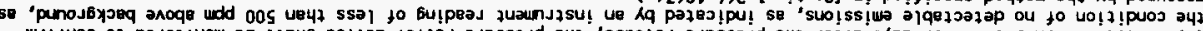

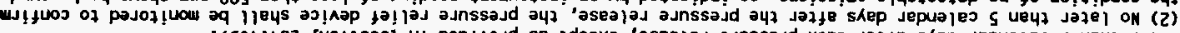

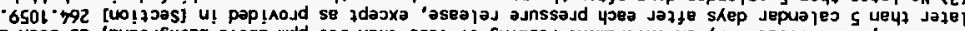

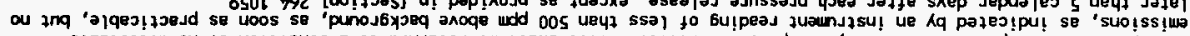

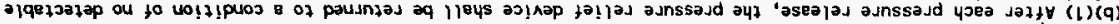
(0)E90! 492 [uo! 7 Jas] U! pa! H! Jads poyjau

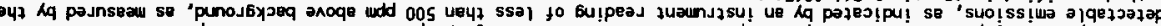

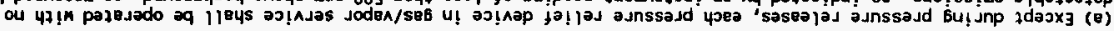

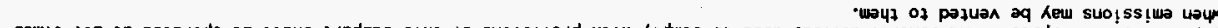

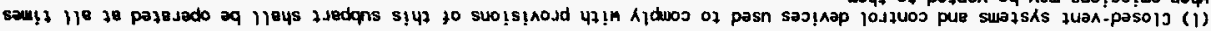

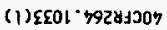

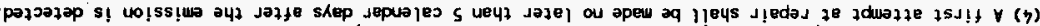

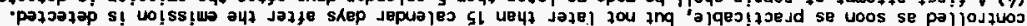

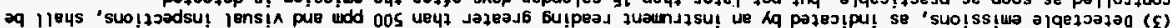

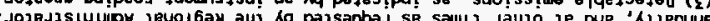

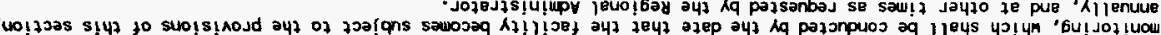

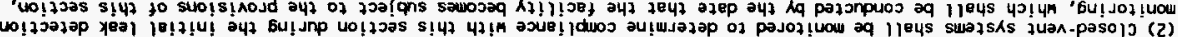

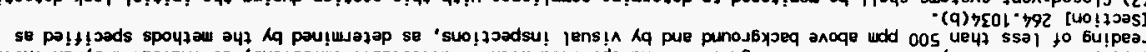

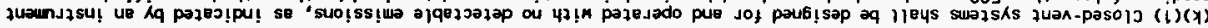

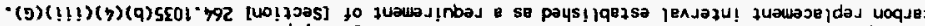

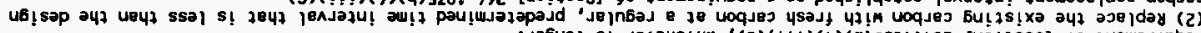

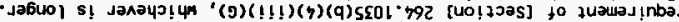

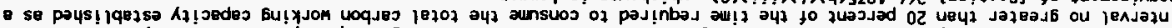

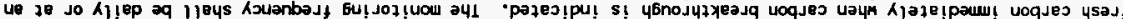

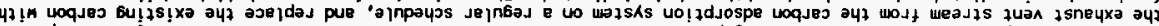

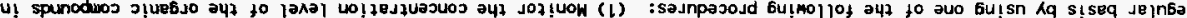
10 ug כ כ

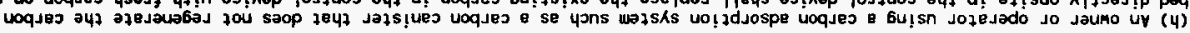

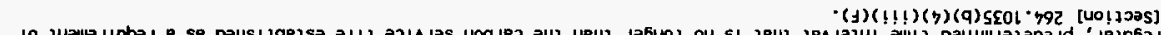

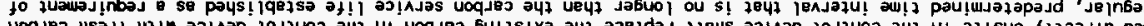

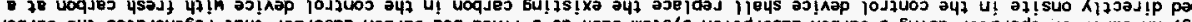

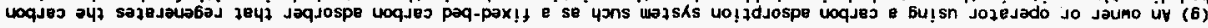

jajeay ssajojd jo

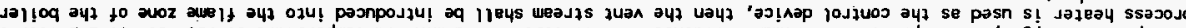

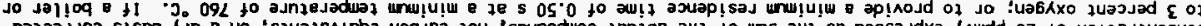

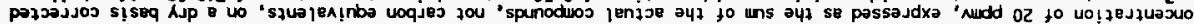

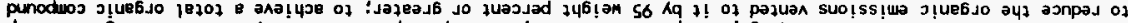

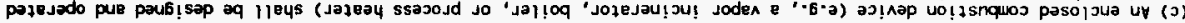

Uo!̣d!̣josag qu!̣edzsuoj

(4) $2501 \cdot 7924130$ H

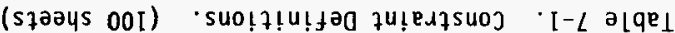




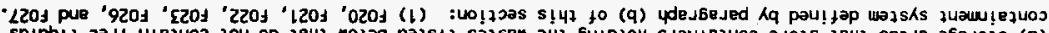

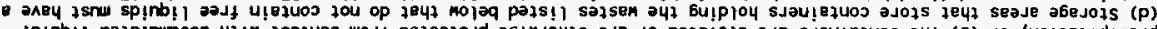

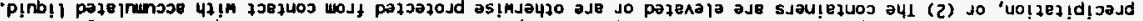

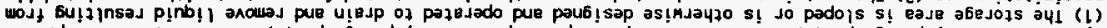

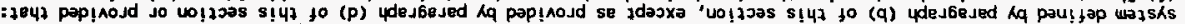

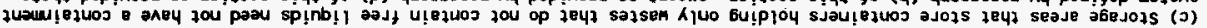

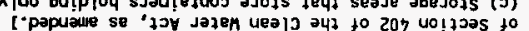

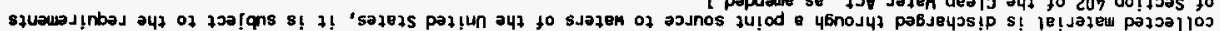

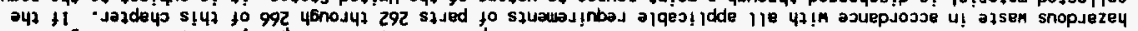

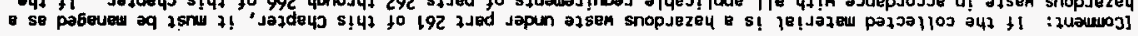

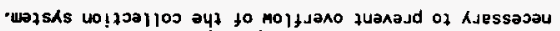

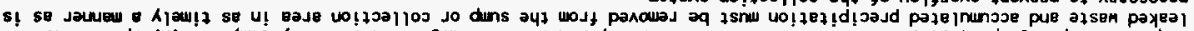

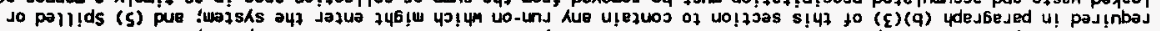

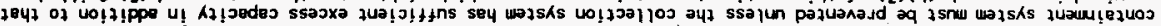

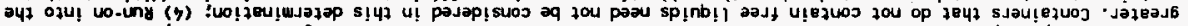

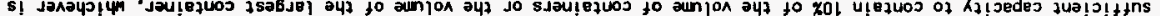

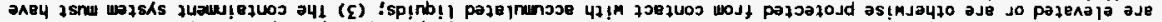

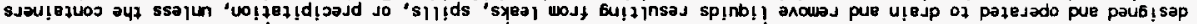

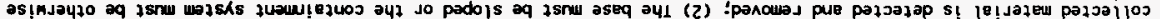
כ43 llun

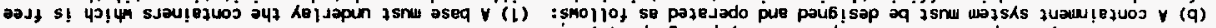
(q) 4 dej60

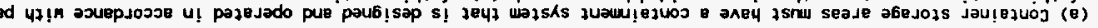

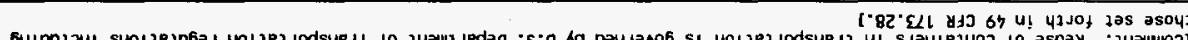

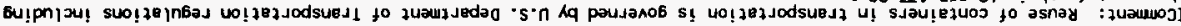

-xeal or 21 asnes jo jaulazuos

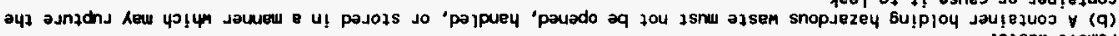

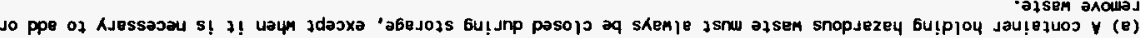

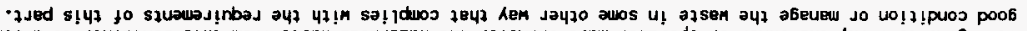
U! s! 2847 Jouị,

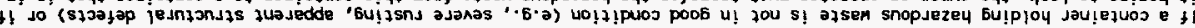

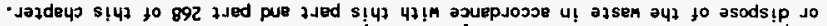

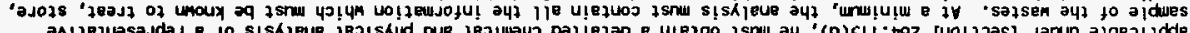

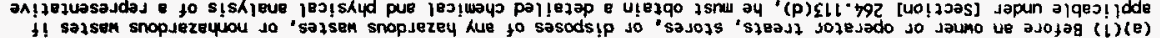


Table 7-1. Constraint Definitions. (100 sheets)

\begin{tabular}{|c|c|}
\hline Constraint Name & Constraint Description \\
\hline 4OCFR264.177 & 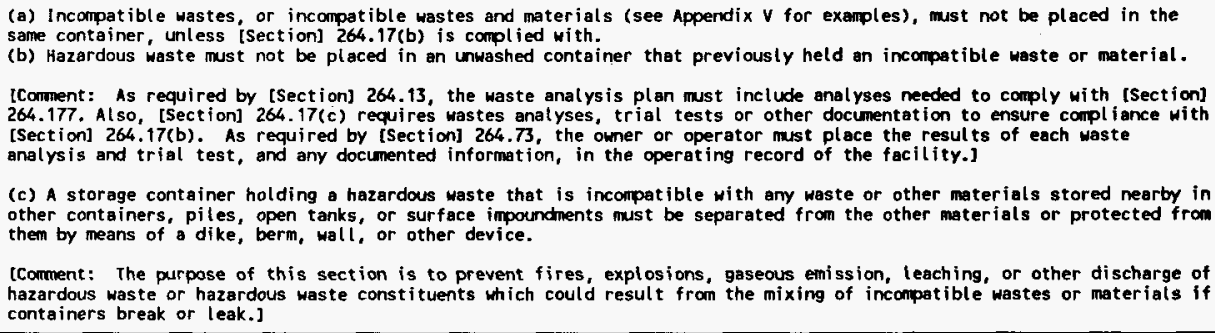 \\
\hline 40CFR50.11(a-b) & $\begin{array}{l}\text { (a) The level of the national primary ambient air quality standard for nitrogen dioxide is } 0.053 \text { parts per million } \\
\text { (100 micrograms per cubic meter), ammual arithmetic mean concentration. } \\
\text { (b) The level of national secondary anbient air quality standard for nitrogen dioxide is } 0.053 \text { perts per million } \\
\text { (100 micrograms per cubic meter). anmual arithmetic mean concentration. }\end{array}$ \\
\hline 4OCFR50.12 & $\begin{array}{l}\text { National primary and secondary antient air quality standards for lead and its compounds, measured as elemental lead by a } \\
\text { reference method based on Appendix of to this part, or by an equivalent method, are: } 1.5 \text { micrograms per cubic meter, } \\
\text { maximm arithmetic mean averaged over a colendar quarter. }\end{array}$ \\
\hline 4OCFR50.5 & $\begin{array}{l}\text { The national secondary anbient air quality standard for sulfur oxide measured as sulfur dioxide by the reference method } \\
\text { described in Appendix A to this part, or by any equivalent method is } 1,300 \text { micrograms per cubic meter }(0.5 \text { p.p.m.) } \\
\text { maximum } 3 \text {-hour concentration not to be exceeded more than once per year. }\end{array}$ \\
\hline 40CFR50.6 & 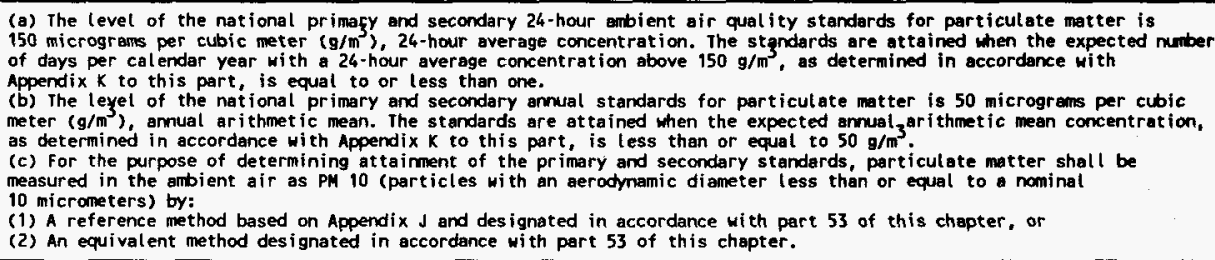 \\
\hline
\end{tabular}


Table 7-1. Constraint Definitions. (100 sheets)

\begin{tabular}{|c|c|}
\hline Constraint Name & Constraint Description \\
\hline 4OCFR50.8(a) & $\begin{array}{l}\text { (a) The national primary ambient air quality standards for carbon monoxide are: } \\
\text { (1) } 9 \text { parts per million ( } 10 \text { milligrams per cubic meter) for an } 8 \text {-hour average concentration not to be exceeded more than } \\
\text { once per year and } \\
\text { (2) } 35 \text { parts per million ( } 40 \text { milligrams per cubic meter) for a i-hour average concentration not to be exceeded more than } \\
\text { once per year. }\end{array}$ \\
\hline 40CFR50.9 & 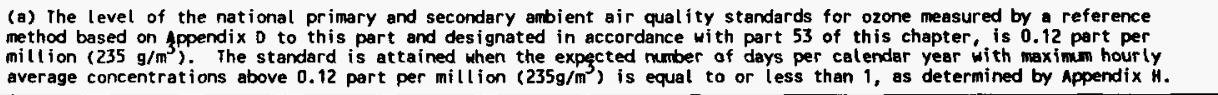 \\
\hline Criticality & $\begin{array}{l}\text { The criticality safety program defined herein applies to all storing, retrieving, processing, transfer operations, } \\
\text { transport and storage activities and waste form operations involving fissionable material quantities in excess of } 3 \% \text { of a } \\
\text { minimum critical mass. } \\
\text { Designs shall incorporate sufficient factors of safety to require at least two unlikely, independent, and concurrent } \\
\text { changes in process conditions before a criticality accident is possible. Protection shall be provided by either (a) the } \\
\text { control of two independent process parameters (which is the preferred approach, if practical) or (b) a system of multiple } \\
\text { (at least two) controls of a single parameter. In all cases, no single credible failure shall result in the potential for } \\
\text { a criticality accident. The basis for selecting one approach over another shall be fully documented. New criticality } \\
\text { safety evaluations (cSEs) and major revisions to existing cSEs shall provide this documentation; existing cSEs are not } \\
\text { required to be revised just to provide this documentation. }\end{array}$ \\
\hline $\begin{array}{l}\text { Design Loads for } \\
\text { Facilities }\end{array}$ & 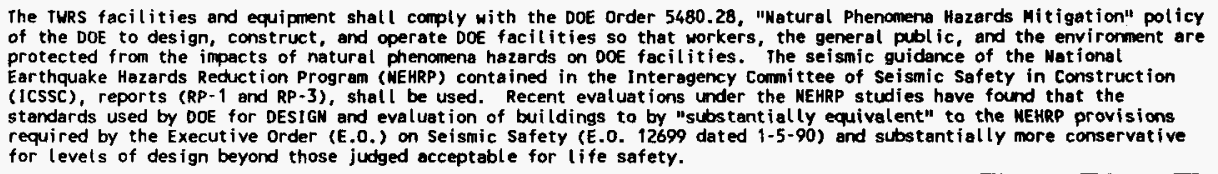 \\
\hline $\begin{array}{l}\text { DOE/RH-0351P, reV.1, } \\
3.2 .1 .2\end{array}$ & $\begin{array}{l}\text { SNF Receipt } \\
\text { (Purchaser/Producer) Until the SNF or HLW is accepted by WA, the Purchaser/Producer shall provide and pay the costs of } \\
\text { interim storage for their respective sites. [WWPA Section } 111(a)(5)]\end{array}$ \\
\hline $\begin{array}{l}\text { DOE/RH-0351P, rev.1, } \\
3.2 .1 .3\end{array}$ & $\begin{array}{l}\text { HLW Receipt } \\
\text { (WA) WA shall begin accepting HLW for disposal at the MGDS begiming in 2015. [Derived] }\end{array}$ \\
\hline $\begin{array}{l}\text { DOE/RU-0351P, rev.1, } \\
3.2 .3 .2 .2(\mathrm{C})\end{array}$ & $\begin{array}{l}\text { (WA) WA shall not accept in excess of } 300 \text { canisters of commercial HLW and } 13,200 \text { canisters of defense HLW for } \\
\text { disposal at the first repository. [Derived] CIBR> }\end{array}$ \\
\hline
\end{tabular}


Table 7-1. Constraint Definitions. (100 sheets)

\begin{tabular}{|c|c|}
\hline Constraint Name & Constraint Description \\
\hline $\begin{array}{l}\text { DOE/RW-0351P, rev.1, } \\
3.2 .3 .2 .3 \mathrm{~A}(2)\end{array}$ & $\begin{array}{l}\text { WA-Transportation Interface Requirements } \\
\text { The types of interfaces between these two elements reflect transfer of both loaded and unloaded transportation cask } \\
\text { subsystems and the documentation, reports and communications regarding loaded and unloaded transportation cask } \\
\text { subsystems. } \\
\text { A. (WA) In support of the following requirements, WA shall arrange for a transportation cask system(s) and necessary } \\
\text { Transportation System services to move SWF and/Or HLW from the Purchaser's/Producer's site to [the CRWMS facility. } \\
\text { [10CFR961.11 Article IV.B.2] } \\
\text { (2) Producers shall be provided with a rail cask for delivery of defense HLW (from-Savarnah River site and from-Hanford) } \\
\text { to the MEDS. [Derived] }\end{array}$ \\
\hline $\begin{array}{l}\text { DOE/RW-0351P, rev.1, } \\
3.4 .4\end{array}$ & $\begin{array}{l}\text { Test Plans and Procedures } \\
\text { (UA, Purchaser, Producer) Through test and evaluation, conformance of the system el ement's requirements shall be } \\
\text { demonstrated as required in the verification matrix in Jable } 4-1 \text {. [CRD] }\end{array}$ \\
\hline $\begin{array}{l}\text { DOE/RW-0351P, rev.1, } \\
\text { 3.7.1.2.1 }\end{array}$ & 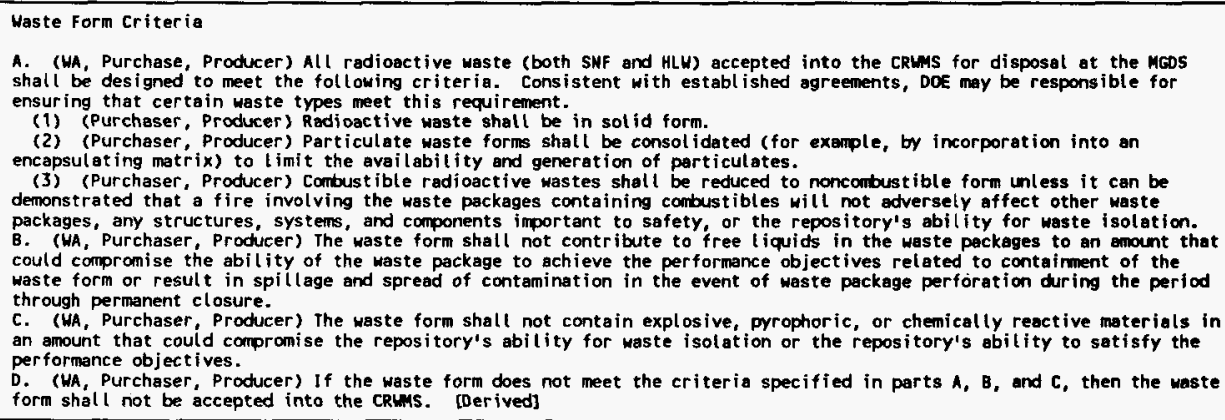 \\
\hline $\begin{array}{l}\text { DOE/RW-0351P, rev.1, } \\
3.7 .1 .2 .1 .2\end{array}$ & $\begin{array}{l}\text { HLW Specifications } \\
\text { (WA) WA shatl accept standard and nonstandard HLW described in sections 3.7.1.2.1.2.1 and 3.7.1.2.1.2.3, respectively. } \\
\text { [Derived } \\
\text { Detailed design requirements are to be addressed in the WA Design Requirements Document. }\end{array}$ \\
\hline
\end{tabular}


Table 7-1. Constraint Definitions. (100 sheets)

\begin{tabular}{|c|c|}
\hline Constraint Name & Constraint Description \\
\hline $\begin{array}{r}\text { DOE/RW-0351P, rev.1, } \\
3.7 .1 .2 .1 .2 .1\end{array}$ & 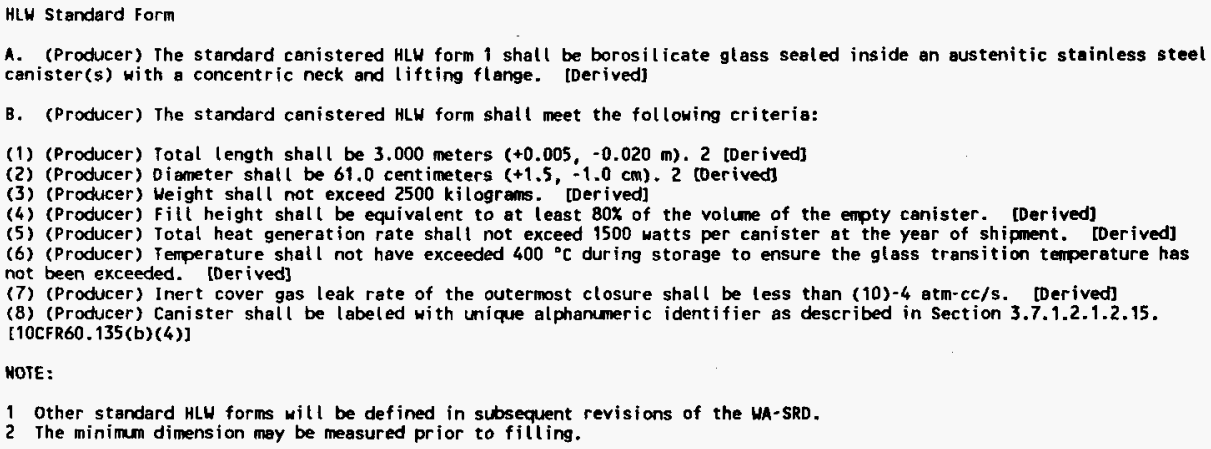 \\
\hline $\begin{array}{l}\text { DOE/RW-0351P, rev.1, } \\
\text { 3.7.1.2.1.2.10(A) }\end{array}$ & $\begin{array}{l}\text { Removable Radioactive Contamination on Canister } \\
\text { A. (Producer) The levels of removable radioactive contamination of all external surfaces of each canistered waste form } \\
\text { shali not exceed } 220 \mathrm{dpm} / 100 \mathrm{~cm}^{2} \text { for atpha radiation and } 2200 \mathrm{dpm} / 100 \mathrm{~cm} \text { for beta and gammadiation. [Derived] }\end{array}$ \\
\hline $\begin{array}{l}\text { DOE/RU-035IP, rev.1, } \\
3.7 .1 .2 .1 .2 .10(B)\end{array}$ & $\begin{array}{l}\text { 8. (Producer) The Producer shall inspect the canistered waste form and remove visible waste glass from the exterior } \\
\text { surface of the canister prior to shipment. [Derived] }\end{array}$ \\
\hline $\begin{array}{l}\text { DOE/RH-0351P, rev.1, } \\
\text { 3.7.1.2.1.2.10(C) }\end{array}$ & $\begin{array}{l}\text { C. (Producer) The Producer shall report to DOE-OCRLin an estimate of the amount of canister material (particularly wall } \\
\text { thickness) removed during decontamination of the canister surface. [Derived] }\end{array}$ \\
\hline $\begin{array}{l}\text { DOE/RW-0351P, rev.1, } \\
\text { 3.7.1.2.1.2.11(A) }\end{array}$ & $\begin{array}{l}\text { HLW Phase Stabitity and Integrity } \\
\text { A. (Producer) The Producer shall ensure the phase structure and composition of the canistered waste form are not } \\
\text { degraded after initial cooldown by maintaining it below } 400^{\circ} \mathrm{C} \text { to ensure the glass transition temperature is not } \\
\text { exceeded. [Derived] }\end{array}$ \\
\hline $\begin{array}{l}\text { DOE/RH-0351P, rev.1, } \\
3.7 .1 .2 .1 .2 .11(\mathrm{~B})\end{array}$ & $\begin{array}{l}\text { B. (Producer) The Producer shall provide the Time Temperature Iransformation diagrams and data for the canistered waste } \\
\text { form. [Derived] }\end{array}$ \\
\hline
\end{tabular}


Table 7-1. Constraint Definitions. (100 sheets)

\begin{tabular}{|c|c|}
\hline Constraint Name & Constraint Description \\
\hline $\begin{array}{l}\text { DOE/RW-0351P, rev.1, } \\
3.7 .1 .2 .1 .2 .12(\text { A })\end{array}$ & $\begin{array}{l}\text { Hazardous Waste Determination } \\
\text { (WA, Producer) WA shall require the Producer to determine if the HLW is hazardous as follows: } \\
\text { A. (Producer) The Producer shall determine, quantify, and report to OOE-OCRLA the presence of any hazardous waste listed } \\
\text { in 40CFR261.31 through 40CFR261.33, in the waste or in any feed stream proposed for storage or disposal. The listed } \\
\text { waste must be quantified in the WaR, or their absence must be certified in the WaR. [Derived] }\end{array}$ \\
\hline $\begin{array}{l}\text { DOE/RH-035tP, rev.1. } \\
3.7 .1 .2 .1 .2 .12(B)\end{array}$ & $\begin{array}{l}\text { B. (Producer) If no "listed hazardous wastes" are present in the waste or in any feed stream, the Prockucer shall perform } \\
\text { the "Toxicity Characteristics Leaching Procedure" (TCLP) as described in } 55 \text { Federal Register } 26986,6 / 29 / 90 \text {, and other } \\
\text { RCRA characteristics test (s) described in 40CFR261.20 through } 261.24 \text { as appropriate, us ing samples from production runs } \\
\text { or prototypical specimens. Any modifications must have prior DOE-OCRLM approval. The method to be used must be } \\
\text { described in the WCP and results documented in the WOR. }\end{array}$ \\
\hline $\begin{array}{l}\text { DOE/RW-0351P, reV.1, } \\
3.7 .1 .2 .1 .2 .12(\mathrm{C})\end{array}$ & $\begin{array}{l}\text { (Producer) Based on the results of } A \text { and B above, the Producer shall verify in the wor whether or not the waste is } \\
\text { hazardous. [Derived] }\end{array}$ \\
\hline $\begin{array}{l}\text { OOE/RW-0351P, rev.1, } \\
3.7 .1 .2 .1 .2 .12(0)\end{array}$ & $\begin{array}{l}\text { D. (Producer) For hazardous wastes, the Producer shall prepare "Hazardous Waste Manifest" logs as required by } 40 \mathrm{ccF} 262 . \\
\text { These logs must be included in the Proctuction Records and must accompany waste during shipment. [Derived] }\end{array}$ \\
\hline $\begin{array}{l}\text { DOE/RH-0351P, rev.1, } \\
3.7 .1 .2 .1 .2 .13\end{array}$ & $\begin{array}{l}\text { Consistency Test } \\
\text { A. (Producer) The Producer shall denonstrate control of waste form production by comparing (either directly or } \\
\text { indirectly) melter batch production samples to the Environmental Assessment (EA) benchmark glass using the Product } \\
\text { Consistency Test (PCT) or equivalent. [Derived] CTBR> } \\
\text { B. (Producer) For acceptance, the concentrations of lithium, sodium, and boron in the leachate, after normalization for } \\
\text { the concentrations in the glass, shall be less than those of the benchmark glass. [Derivedl <iBR> }\end{array}$ \\
\hline $\begin{array}{l}\text { DOE } / R U-0351 P, \text { reV.1, } \\
3.7 .1 .2 .1 .2 .14\end{array}$ & $\begin{array}{l}\text { Canister Impact Characteristics } \\
\text { (Producer) The canistered HLW shall be capable of withstanding a drop of } 7 \text { meters onto a flat, essentially unyielding } \\
\text { surface without breaching or dispersing radionucl ides. The test results shall include information on the measured } \\
\text { canister leak rates and canister deformation after the drop test. [Derived] \&BR> }\end{array}$ \\
\hline $\begin{array}{l}\text { DOE } / R H-0351 P, \text { rev.1, } \\
3.7 .1 .2 .1 .2 .17\end{array}$ & $\begin{array}{l}\text { Dose Rate at Shipment } \\
\text { (Producer) The canistered iaste form shall not exceed a maximu surface gamma dose rate of } 10 E 5 \text { ren/hr and a maximm } \\
\text { neutron dose rate of } 10 \mathrm{rem} / \mathrm{hr} \text {, at the year of shipment to the MGDS. [Derived] }\end{array}$ \\
\hline $\begin{array}{l}\text { DOE/RH-0351P, rev.1, } \\
3.7 .1 .2 .1 .2 .18\end{array}$ & $\begin{array}{l}\text { HLW Condition at Delivery } \\
\text { (Producer) At time of delivery, the HLH shall stand upright without support on a flat horizontal surface and properly fit } \\
\text { into a right-circular, cylindrical cavity }(64 \mathrm{~cm} \text { diameter and } 3.01 \mathrm{~m} \text { (ength). [Derived] }\end{array}$ \\
\hline
\end{tabular}


Table 7-1. Constraint Definitions. (100 sheets)

\begin{tabular}{|c|c|}
\hline Constraint Name & Constraint Description \\
\hline $\begin{array}{l}\text { DOE/RW-0351P, rev.1, } \\
3.7 .1 .2 .1 .2 .19\end{array}$ & 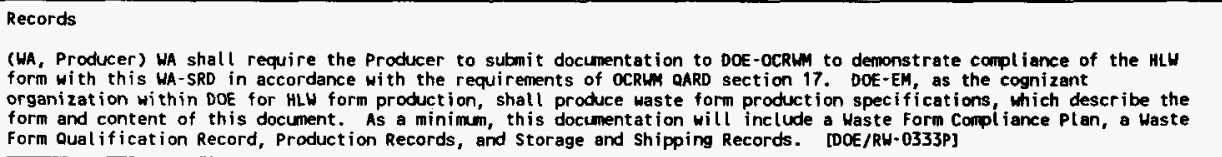 \\
\hline $\begin{array}{l}\text { DOE/RU-0351P, rev.1, } \\
\text { 3.7.1.2.1.2.19.1 }\end{array}$ & 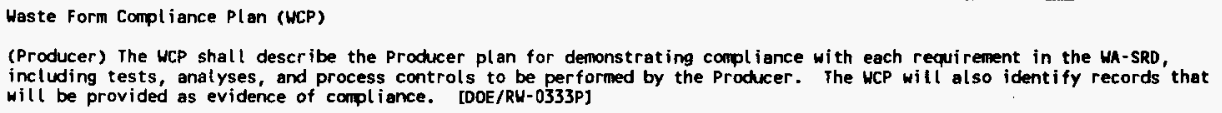 \\
\hline $\begin{array}{l}\text { DOE/RH-0351P rev.1, } \\
\text { 3.7.1.2.1.2.19.2 }\end{array}$ & $\begin{array}{l}\text { Waste Form Qualification Report (WOR) } \\
\text { (Producer) The WCR shall compile the results from waste form testing and analysis to demonstrate the ability of the } \\
\text { Producer to comply with the WA-SRD. [DOE/RH-0333P] }\end{array}$ \\
\hline $\begin{array}{l}\text { DOE/RH-0351P rev.1, } \\
3.7 .1 .2 .1 .2 .19 .3\end{array}$ & $\begin{array}{l}\text { Production Record } \\
\text { (Producer) The Production Records shall describe the actual canistered waste form. [DoE/RW-0333P] }\end{array}$ \\
\hline $\begin{array}{l}\text { OOE/RH-035IP, rev.1, } \\
3.7 .1 .2 .1 .2 .2\end{array}$ & $\begin{array}{l}\text { HLW Wonconforming Form } \\
\text { (Producer) The nonconforming canistered HLW form shall be any HLW that does not conform with the HLW characteristics in } \\
\text { Sections } 3.7 .1 .2 .1 .2 .1 \text { and } 3.7 .1 .2 .1 .2 .4 \text { through } 3.7 .1 .2 .1 .2 .18 \text {. Derived] } \\
\text { The procedures for acceptance of nonconforming canistered HLH are described in Sections } 3.7 .1 .2 .8 \text { and } 3.9 \text {. }\end{array}$ \\
\hline $\begin{array}{l}\text { OOE/RH-0351P, rev.1, } \\
\text { 3.7.1.2.1.2.3 }\end{array}$ & $\begin{array}{l}\text { HLW Nonstandard Form } \\
\text { (Producer) The nonstandard canistered HLW form shall be any HLL with nonconforming conditions that have been reviewed and } \\
\text { deemed acceptable into the CRLMS. Nonstandard canistered HLW may al so be in a condition which requires special handl ing. } \\
\text { [Derived] } \\
\text { The procedure for acceptance of nonstandard HLW is described in Section 3.7.1.2.8A. }\end{array}$ \\
\hline
\end{tabular}


Table 7-1. Constraint Definitions. (100 sheets)

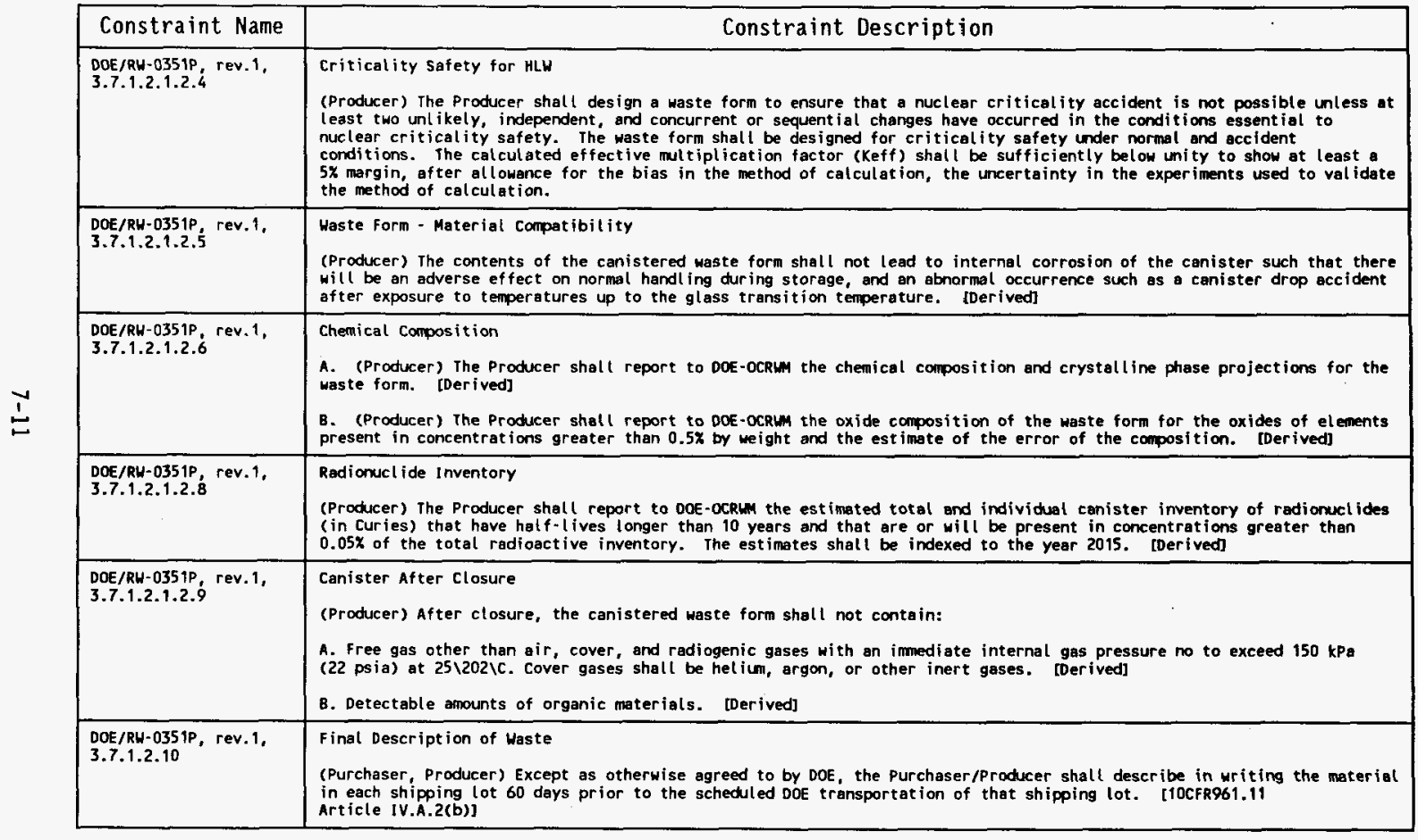


Table 7-1. Constraint Definitions. (100 sheets)

\begin{tabular}{|c|c|}
\hline Constraint Name & Constraint Description \\
\hline $\begin{array}{l}\text { DOE/RW-0351P, rev.1, } \\
3.7 .1 .2 .6\end{array}$ & 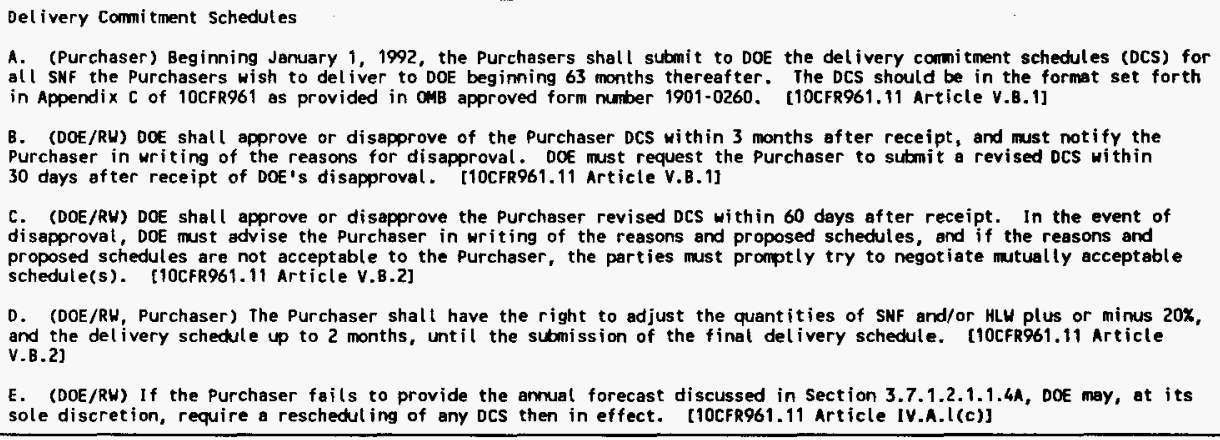 \\
\hline $\begin{array}{l}\text { DOE/RU-0351P, rev.1, } \\
\text { 3.7.1.2.7 }\end{array}$ & $\begin{array}{l}\text { Exchange Requests } \\
\text { A. (Purchaser) Not less than } 6 \text { months prior to the delivery date specified in the Purchaser approved DCS, the Purchaser } \\
\text { shall be allowed to sutmit to DOE an exchange request as specified in 10CFR961.11 Article V.E. [10CFR961.11 Article V.E] } \\
\text { 8. (DDE/RU) DOE shall approve or disapprove the proposed exchange request within } 30 \text { days after receipt. In the event of } \\
\text { disapproval, DOE must advise the Purchaser in writing of the reasons. [10CFR961.11 Article V.E] }\end{array}$ \\
\hline $\begin{array}{l}\text { DOE/RL-035 IP, rev.1, } \\
\text { 3.7.1.2.8 }\end{array}$ & 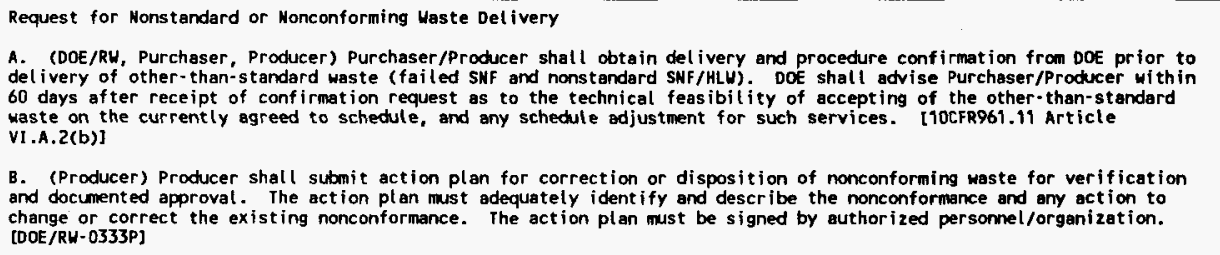 \\
\hline
\end{tabular}


Table 7-1. Constraint Definitions. (100 sheets)

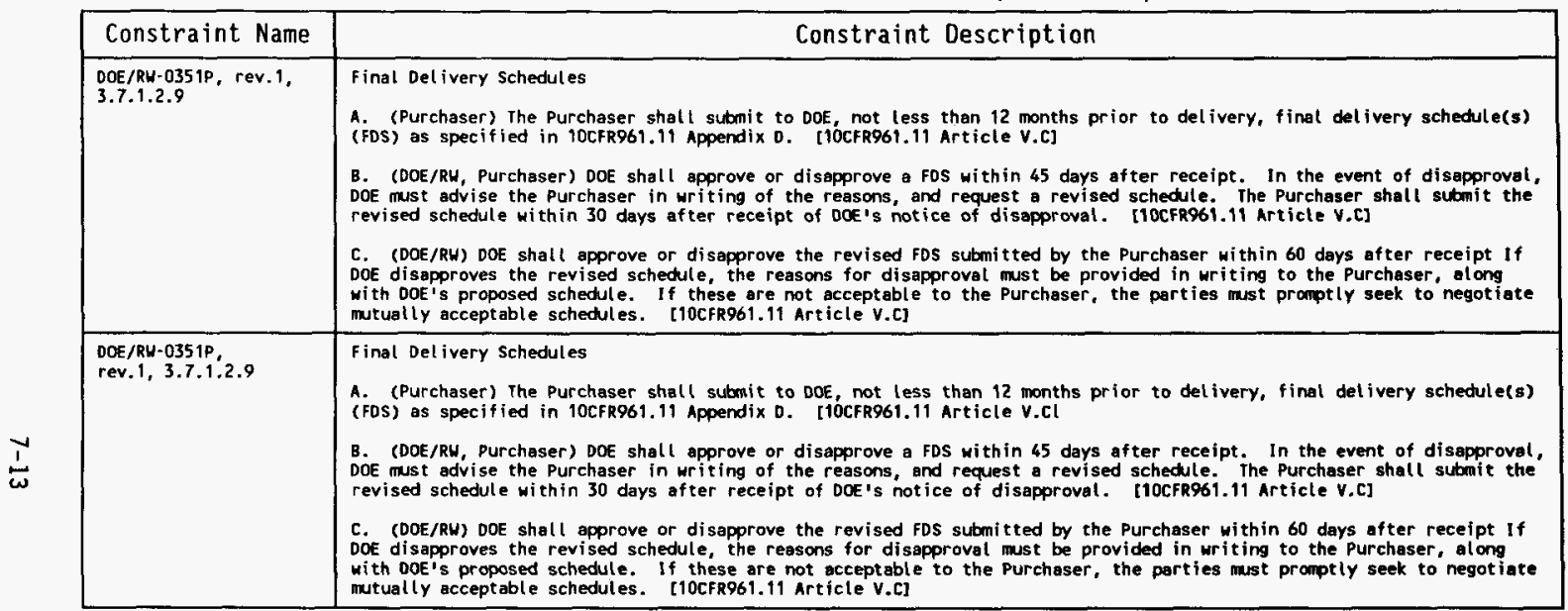


Table 7-1. Constraint Definitions. (100 sheets)

\begin{tabular}{|c|c|}
\hline Constraint Name & Constraint Description \\
\hline $\begin{array}{l}\text { DOE/RH-0351P, rev. } 9 \text {, } \\
\text { 3.7.3.2.1 }\end{array}$ & 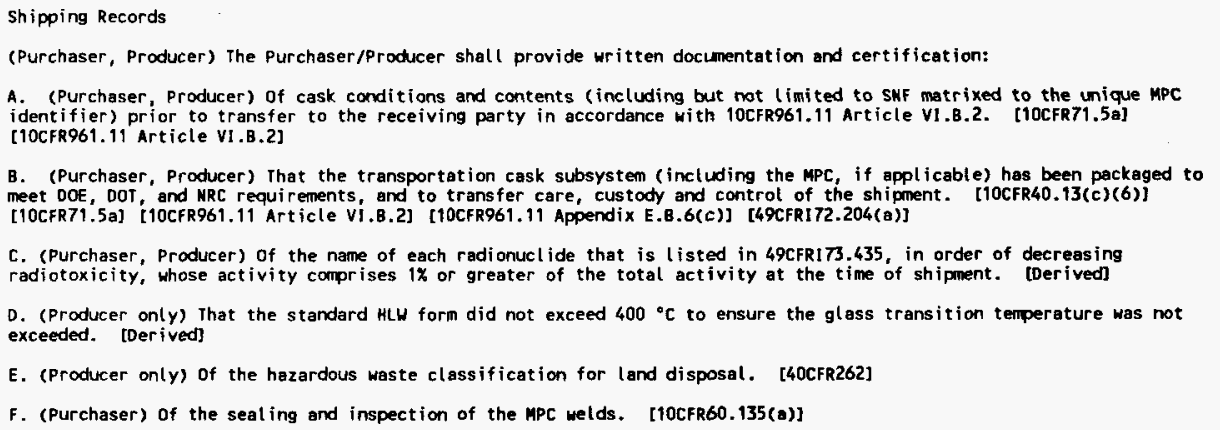 \\
\hline DOE/RW-0351P, rev.1, & $\begin{array}{l}\text { Rout ine Determinations } \\
\text { (Purchaser, Producer) Prior to each shipment of licensed material, the Purchaser/Proctucer shall ensure the transportation } \\
\text { cask with its contents satisfies the applicable requirenents of 10CFR71.87. [10CFR71.87] }\end{array}$ \\
\hline $\begin{array}{l}\text { DOE/RH-0351P, rev.1, } \\
3.7 .3 .2 .4(B)\end{array}$ & $\begin{array}{l}\text { B. (DOE/RW, Producer) DOE-OCRWM shall accept HLW at a designated loading facility adjacent to the Producer's HLH } \\
\text { facility. [DHLU: MOA between DP and RH, 1986] [CHLL: Derived] <TBR> }\end{array}$ \\
\hline DOE/RU-0351P, rev.1, & $\begin{array}{l}\text { c. (DOE/RH, Purchaser, Producer) Title to SNF and/or HLW shall transfer to DOE at the Purchaser/Producer site. DOE shall } \\
\text { be solely responsible for control of all I material upon transfer of title. DOE has the right to dispose, as it sees } \\
\text { fit, of any SHF and/Or HLW to which it has thaken title. Purchasers/Producers shall have no claim against DoE or the } \\
\text { Government for such SNF or HLH, nor shall the Goverment be obligated to compensate the Purchaser/Producer for such } \\
\text { material. IPurchaser: 10CFR61.11 Article VIII [Producer: Derived] }\end{array}$ \\
\hline
\end{tabular}


Table 7-1. Constraint Definitions. (100 sheets)

\begin{tabular}{|c|c|}
\hline Constraint Name & Constraint Description \\
\hline $\begin{array}{l}\text { DOE/RW-0351P，rev.1, } \\
\begin{array}{l}3.7 .3 .2 .5\end{array}\end{array}$ & 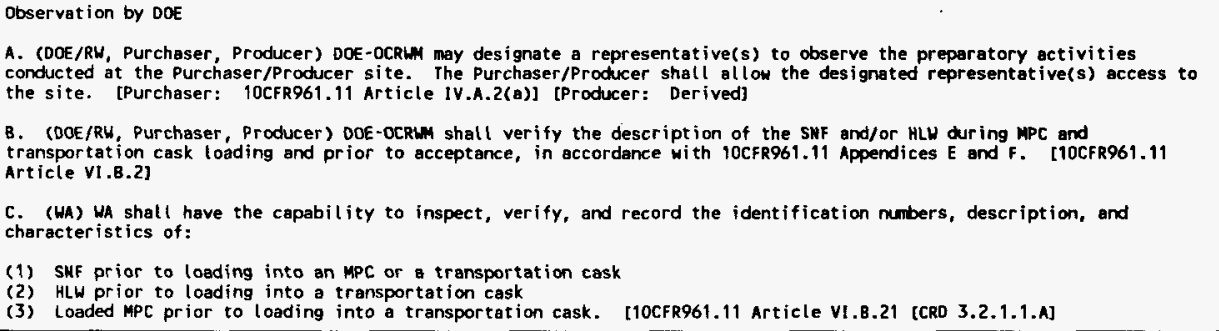 \\
\hline $\begin{array}{l}\text { DOE/RH-035 tP, rev.1, } \\
\text { 3.7.3.2.6 }\end{array}$ & 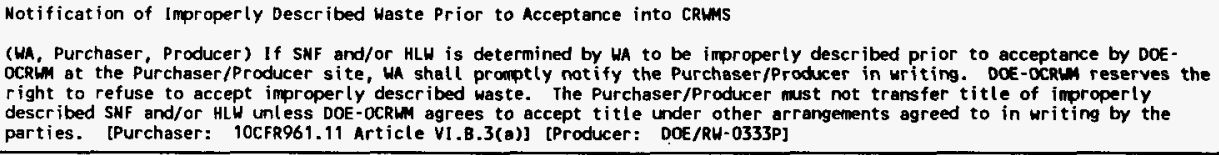 \\
\hline $\begin{array}{l}\text { DOE/RU-0351P, rev.1, } \\
\text { 3.7.3.2.8 }\end{array}$ & $\begin{array}{l}\text { Initial Inventory Reporting } \\
\text { (WA, Purchaser) A Material Balance Report (DOE/NRC Form-742) shall be completed and distributed reporting initisl } \\
\text { inventory. [10CFR72.76] [10CFR75.31] [10CFR75.32] [CRD 3.3.8.2C] }\end{array}$ \\
\hline $\begin{array}{l}\text { DOE/RU-0351P, rev.1, } \\
3.7 .4 .2 .1\end{array}$ & $\begin{array}{l}\text { Resolution of Improperly Described Waste After Acceptance into CRLMS } \\
\text { (WA, Purchaser, Producer) If subsequent to its acceptance, WA finds SNF and/or HLW is improperly described, WA shall } \\
\text { promptly notify the Purchaser/Producer in writing of such a finding. In this event, the Purchaser/Producer must provide } \\
\text { WA with a proper description within } 30 \text { days. In the event that the Purchaser/Producer fails to provide the proper } \\
\text { description, DOE may hold in abeyance any and all further deliveries scheduled. [10CFR961.11 Article VI.B.3(b)] } \\
\text { [DOE/RW-0333P] }\end{array}$ \\
\hline
\end{tabular}


Table 7-1. Constraint Definitions. (100 sheets)

\begin{tabular}{|c|c|}
\hline Constraint Name & Constraint Description \\
\hline $\begin{array}{l}\text { DOE/RW-0351P, rev. } 1 \text {, } \\
3.9\end{array}$ & 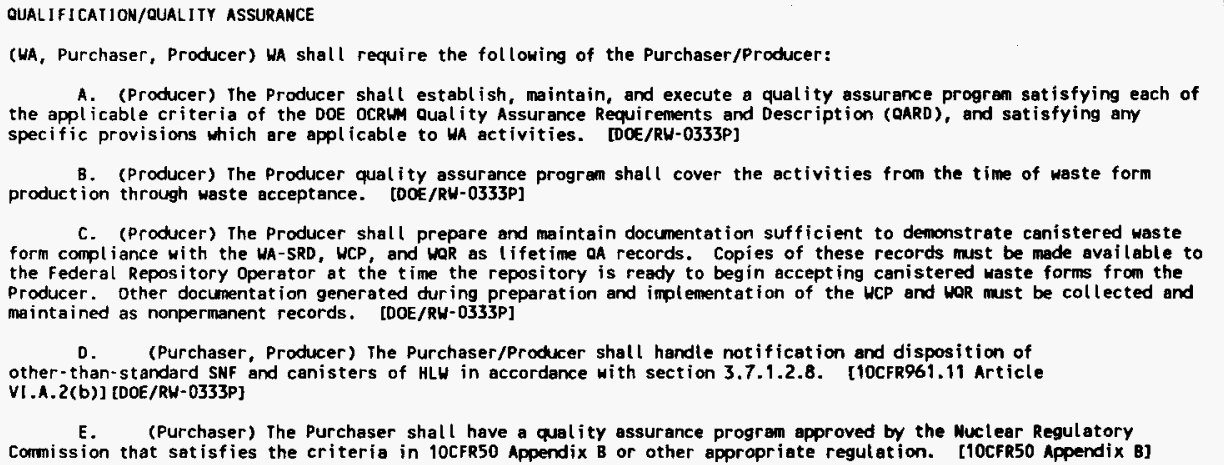 \\
\hline
\end{tabular}


Table 7-1. Constraint Definitions. (100 sheets)

\begin{tabular}{|c|c|}
\hline Constraint Name & Constraint Description \\
\hline DOE/HIPP-069, rev.4, & 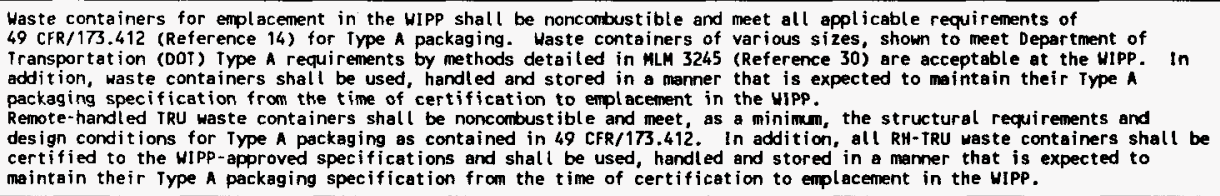 \\
\hline $\begin{array}{l}\text { DOE/HIPP-069, rev.4, } \\
3.2 .2 .6\end{array}$ & 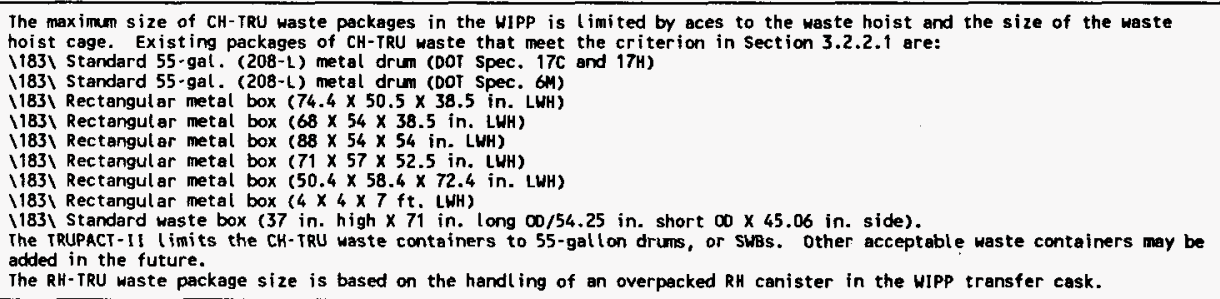 \\
\hline $\begin{array}{l}\text { DOE/UIPP-069, rev.4, } \\
3.3 .1 .1\end{array}$ & $\begin{array}{l}\text { Pounders, ashes, and similar particulate waste materials shall be immobilized if more than } 1 \text { weight percent of the waste } \\
\text { matrix in each package is in the form of particulate below } 10 \text { microns in diameter, or if more than } 15 \text { weight percent is } \\
\text { in the form of particles below } 200 \text { microns in diameter. }\end{array}$ \\
\hline
\end{tabular}


Table 7-1. Constraint Definitions. (100 sheets)

\begin{tabular}{|c|c|}
\hline Constraint Name & Constraint Description \\
\hline $\begin{array}{l}\text { DOE/WIPP-069, rev.4, } \\
3.3 .2\end{array}$ & 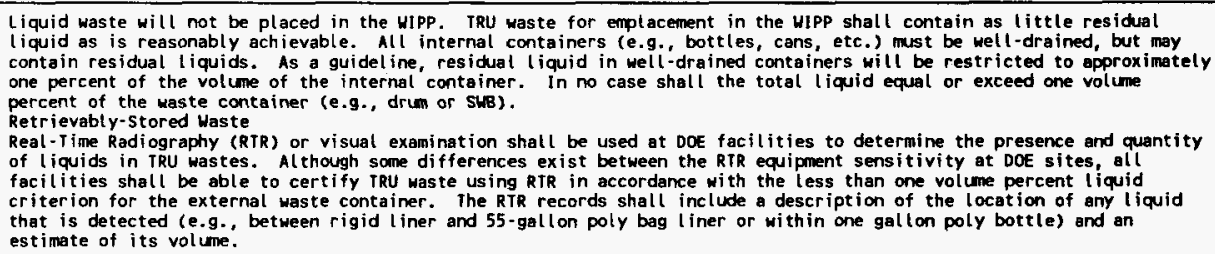 \\
\hline $\begin{array}{l}\text { DOE/HIPP-069, rev.4, } \\
3.3 .2 .2\end{array}$ & $\begin{array}{l}\text { Waste for shipment in TRUPACT-11 shall contain less then } 1 \text { volume percent of the waste container as liquids. } \\
\text { Same as TRUPACT-1I requirements. (This requirement is anticipated based on initial negotiations with the NRC, but will } \\
\text { not be finalized untit review is complete and a } C \text { of } c \text { is issued.) }\end{array}$ \\
\hline $\begin{array}{l}\text { DOE/WIPP-069, rev.4, } \\
3.3 .3 .1\end{array}$ & $\begin{array}{l}\text { WIPP OPERATIONS ANO SAFETY CRITERIA } \\
\text { Contact-Handled and Remote Handled Wastes } \\
\text { Pyrophoric materials, other than radionuclides, shall be rendered safe by mixing them with chemically stable materials } \\
\text { (e. } . \text { concrete, glass) or shall be processed to remove their hazardous properties. Not more than one percent by weight } \\
\text { of the waste in each waste container may be pyrophoric forms of radionuclides, and these shall be generally dispersed in } \\
\text { the waste. }\end{array}$ \\
\hline $\begin{array}{l}\text { DOE/WIPP-069, rev.4, } \\
3.3 .4 .5\end{array}$ & $\begin{array}{l}\text { Documented procedures or RTR verifications are used to ensure that individual waste packages contain no pressurized } \\
\text { vessels. Documented procedures are al so used to exclude explosive items, componds, or continination of materials that } \\
\text { could form explosive compounds within the waste package. If such materials are present, they maist be treated or diluted } \\
\text { such that a detonation is not possible. }\end{array}$ \\
\hline
\end{tabular}


Table 7-1. Constraint Definitions. (100 sheets)

\begin{tabular}{|c|c|}
\hline Constraint Name & Constraint Description \\
\hline DOE/WIPP-069, rev.4, & 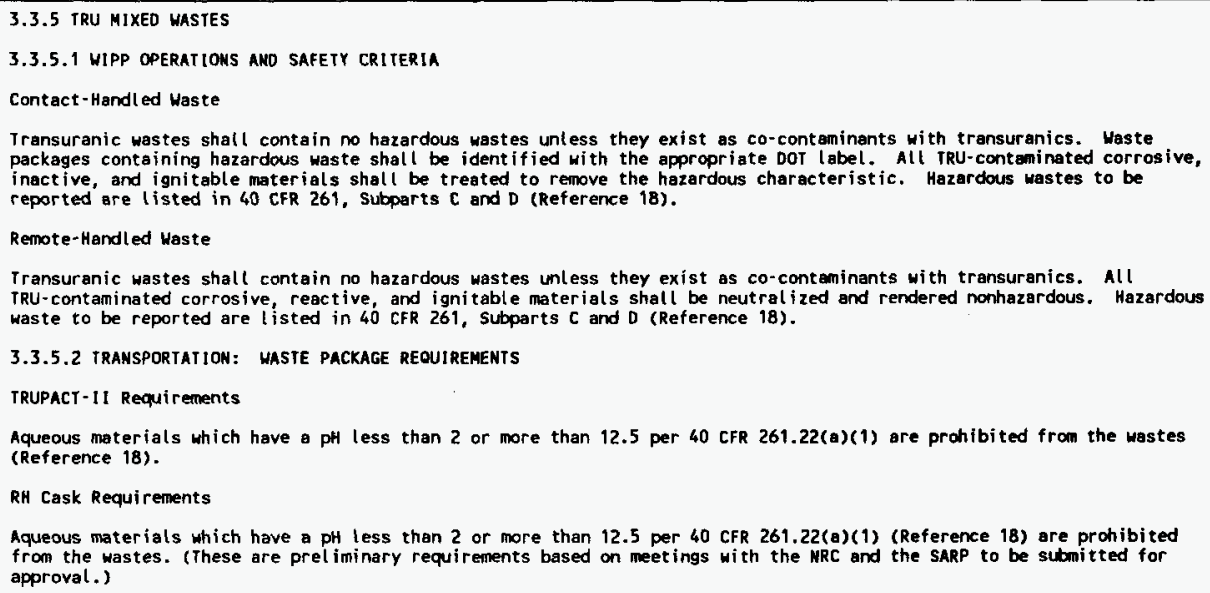 \\
\hline
\end{tabular}


Table 7-1. Constraint Definitions. (100 sheets)

\begin{tabular}{|c|c|}
\hline Constraint Name & Constraint Description \\
\hline $\begin{array}{l}\text { DOE/WIPP-069, rev. } 4 \text {, } \\
3.3 .5 .3(7)^{\star}\end{array}$ & 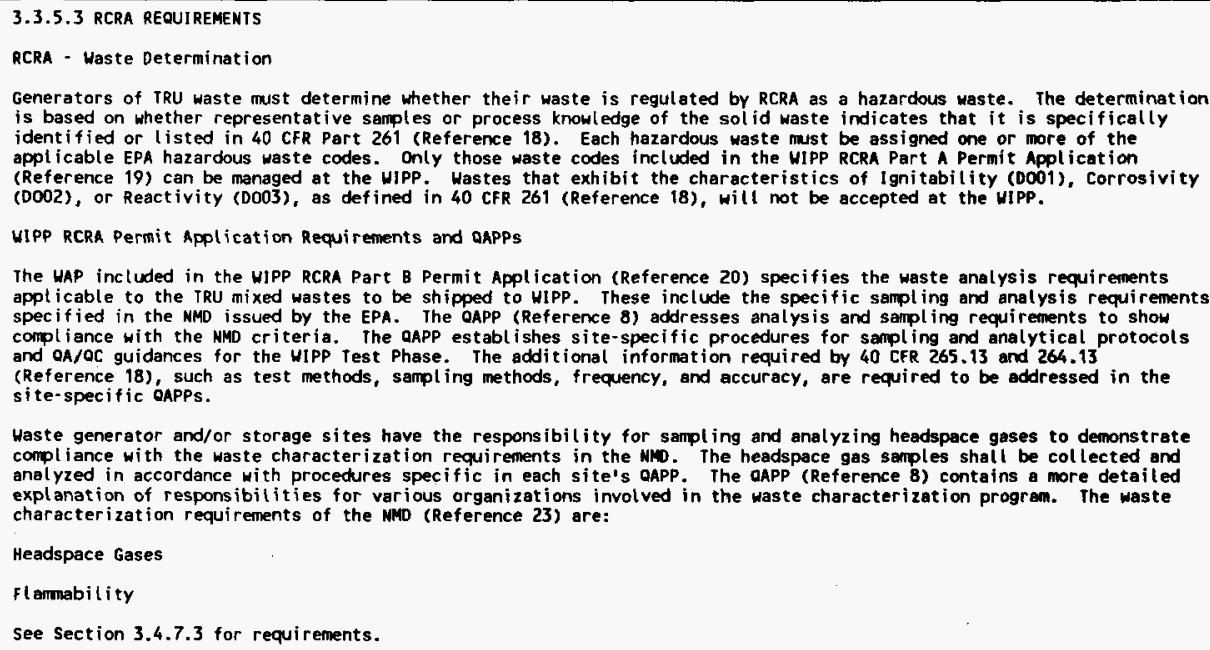 \\
\hline
\end{tabular}


Table 7-1. Constraint Definitions. (100 sheets)

\begin{tabular}{|c|c|}
\hline Constraint Name & Constraint Description \\
\hline $\begin{array}{l}\text { DOE/WIPP-069, rev.4, } \\
3.3 .5 .3(2)^{*}\end{array}$ & 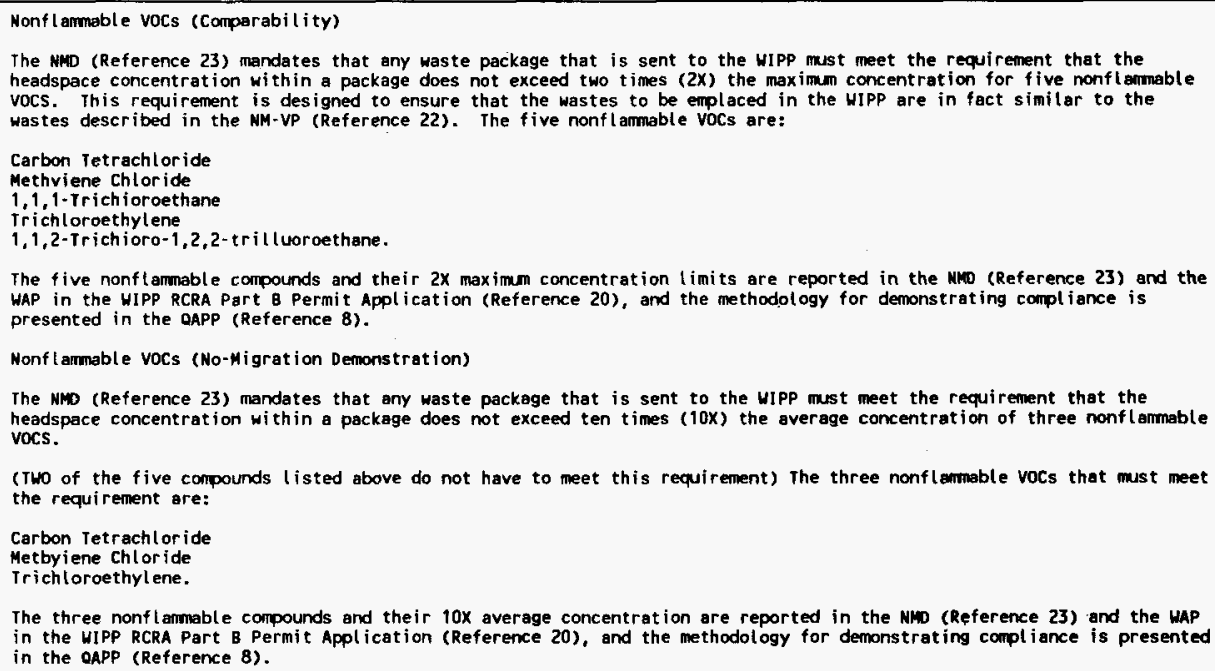 \\
\hline
\end{tabular}


Table 7-1. Constraint Definitions. (100 sheets)

\begin{tabular}{|c|c|}
\hline Constraint Name & Constraint Description \\
\hline $\begin{array}{l}\text { DOE/HIPP-069, rev.4, } \\
3.3 .5 .3(3)-3.3 .5^{*}\end{array}$ & 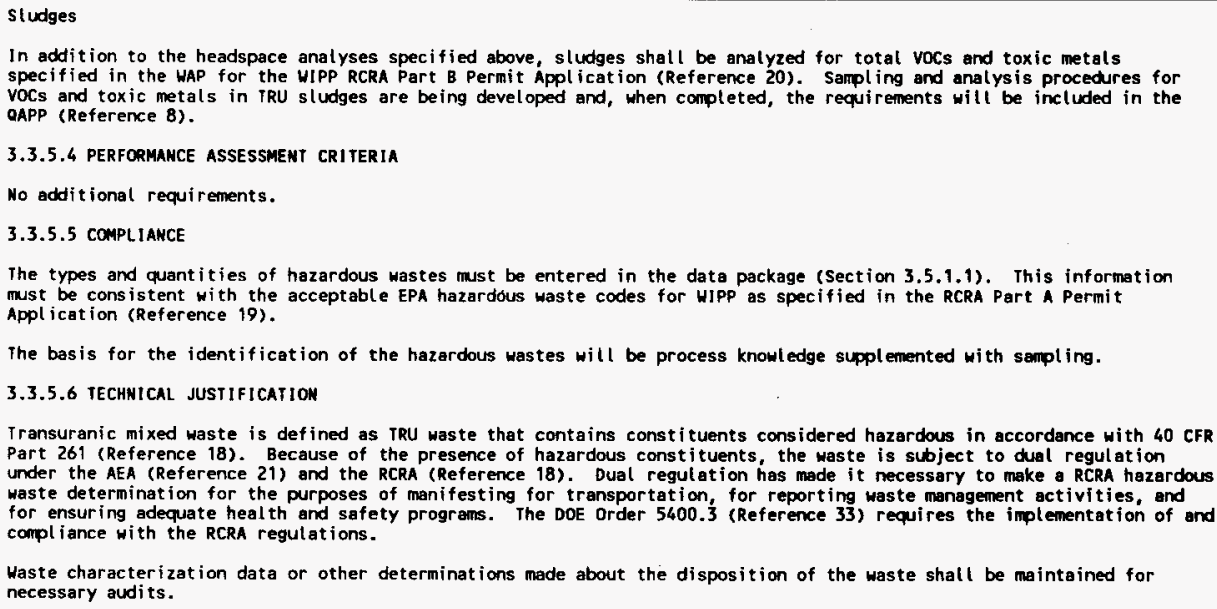 \\
\hline
\end{tabular}


Table 7-1. Constraint Definitions. (100 sheets)

\begin{tabular}{|c|c|}
\hline Constraint Name & Constraint Description \\
\hline $\begin{array}{l}\text { DOE/WIPP-069, rev.4. } \\
3.3 .6 .1-3.3 .6 .3^{\star}\end{array}$ & 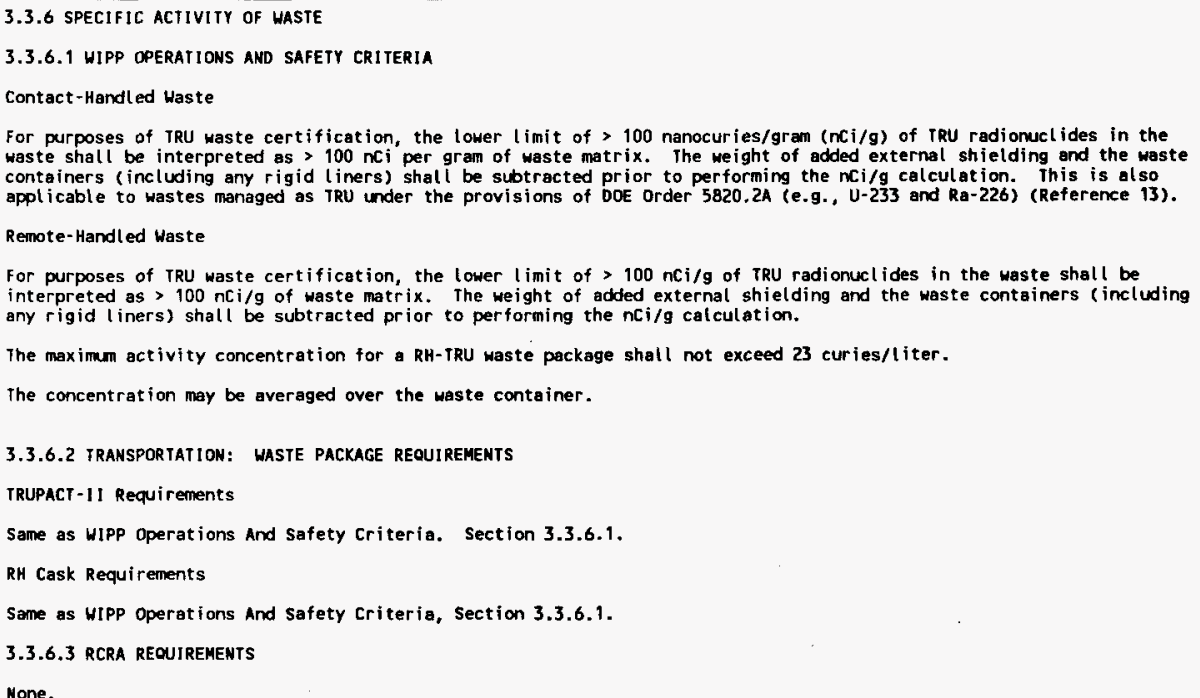 \\
\hline
\end{tabular}


Table 7-1. Constr.t Definitions. (100 sheets)

\begin{tabular}{|c|c|}
\hline Constraint Name & Constraint Description \\
\hline $\begin{array}{l}\text { DOE/WIPP-069, rev.4, } \\
3.3 .6 .4-3.3 .6 .6^{*}\end{array}$ & 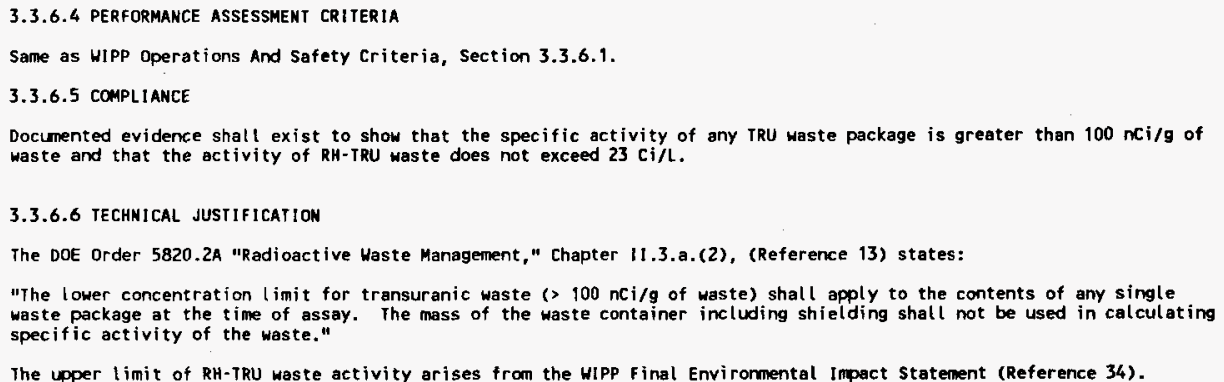 \\
\hline
\end{tabular}


Table 7-1. Constraint Definitions. (100 sheets)

\begin{tabular}{|c|c|}
\hline Constraint Name & Constraint Description \\
\hline $\begin{array}{l}\text { DOE/WIPP-069, rev.4, } \\
3.4 .1 .1-3.4 .1 .3^{\star}\end{array}$ & 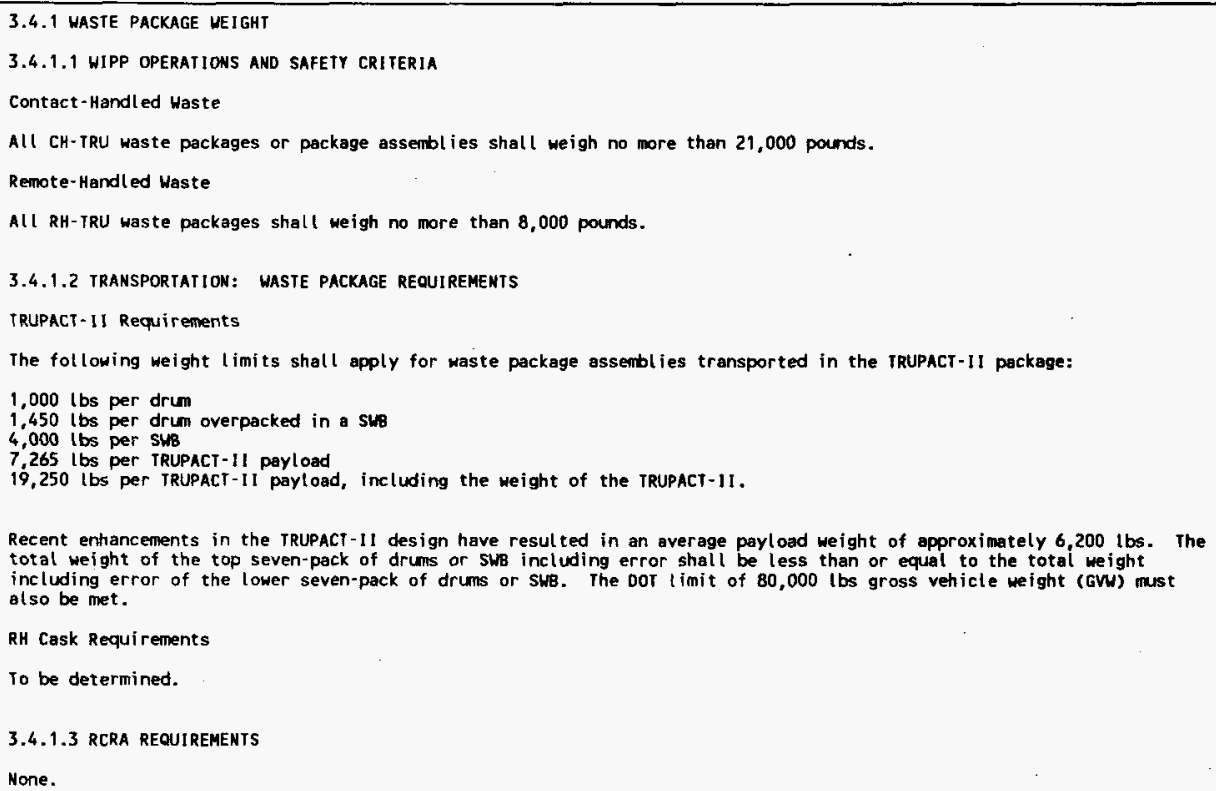 \\
\hline
\end{tabular}


Table 7-1. Constraint Definitions. (100 sheets)

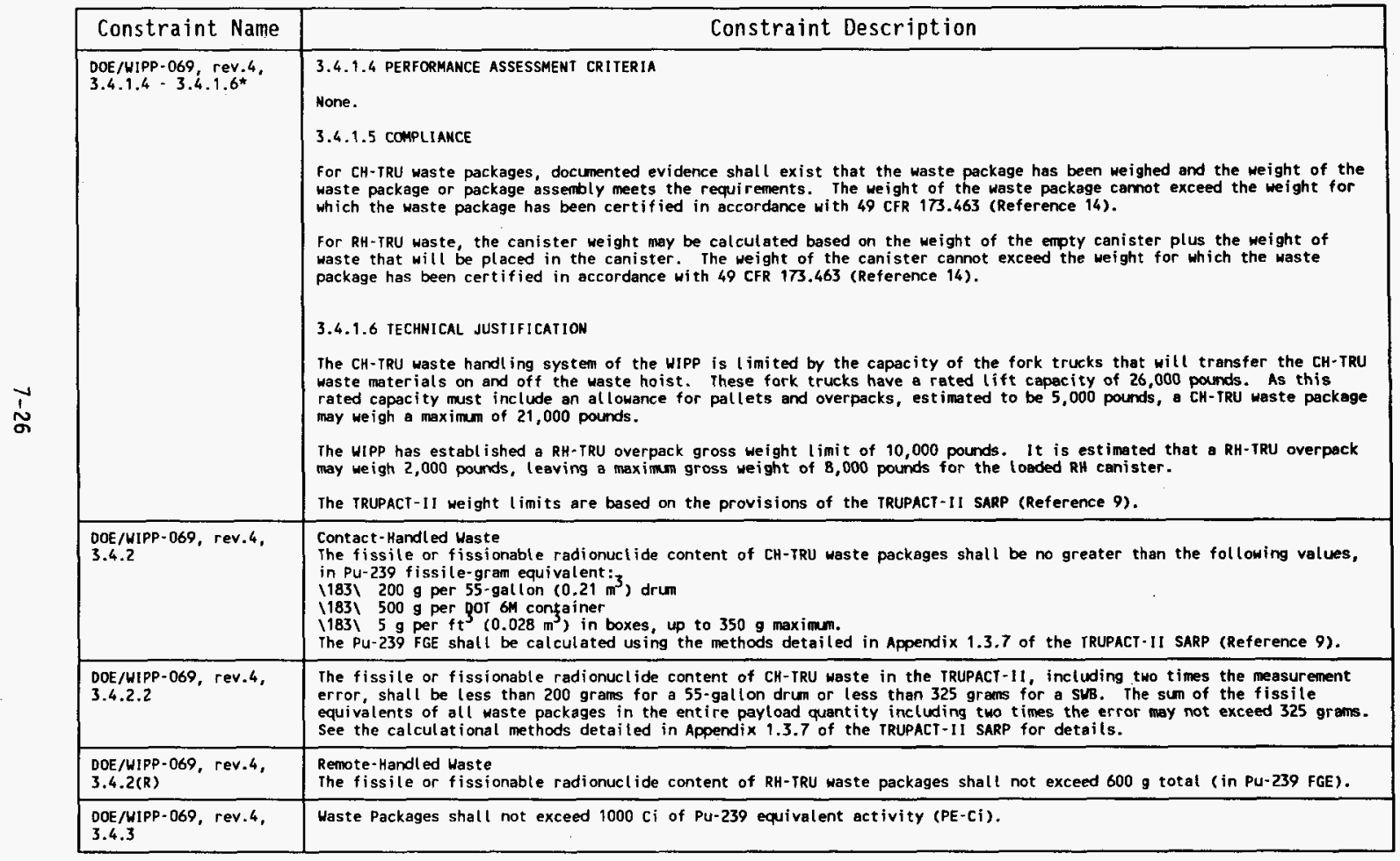


Table 7-1. Constraint Definitions. (100 sheets)

\begin{tabular}{|c|c|}
\hline Constraint Name & Constraint Description \\
\hline $\begin{array}{l}\text { DOE/NIPP-069, rev.4, } \\
3.4 .4\end{array}$ & $\begin{array}{l}\text { All RH-TRU waste packages shall have a surface dose rate at any point no greater than } 1000 \text { rem/hr. Weutron contributions } \\
\text { are limited to } 270 \mathrm{mrem} / \mathrm{hr} \text {. Neutron contribut ions of greater than } 20 \mathrm{mrem} / \mathrm{hr} \text {. to the total waste package dose rate shall } \\
\text { be reported in the data package. At least } 95 \% \text { of the RH canisters must have dose rates of } \Leftrightarrow=100 \mathrm{rem} / \mathrm{hr} \text {, and no more than } \\
5 \% \text { of the RH canisters are allowed to have but }<=1000 \mathrm{rem} / \mathrm{hr} \text { may be shipped to the WIPP. }\end{array}$ \\
\hline $\begin{array}{l}\text { DOE/NIPP-069, rev.4, } \\
3.4 .5\end{array}$ & $\begin{array}{l}\text { Removable surface contaminat ion on waste packages or package assembl ies to be emplaced in wIPP shall not be greater than } \\
50 \text { picocuries per } 100 \text { sq. cm for alpha-emitting radionuclides and } 450 \text { picocuries per } 200 \mathrm{sq} \text {. cm for beta-gamma-emitting } \\
\text { radionucl ides. Fixation of surface contamination to meet the above criterion is not permitted. }\end{array}$ \\
\hline $\begin{array}{l}\text { DOE/NIPP-069, rev.4, } \\
3.4 .6\end{array}$ & The thermal power generated by waste materials in any RH-TRU waste package shall not exceed 300 watts. \\
\hline $\begin{array}{l}\text { DOE/NIPP-069, rev.4, } \\
3.5 .1 .1^{*}\end{array}$ & 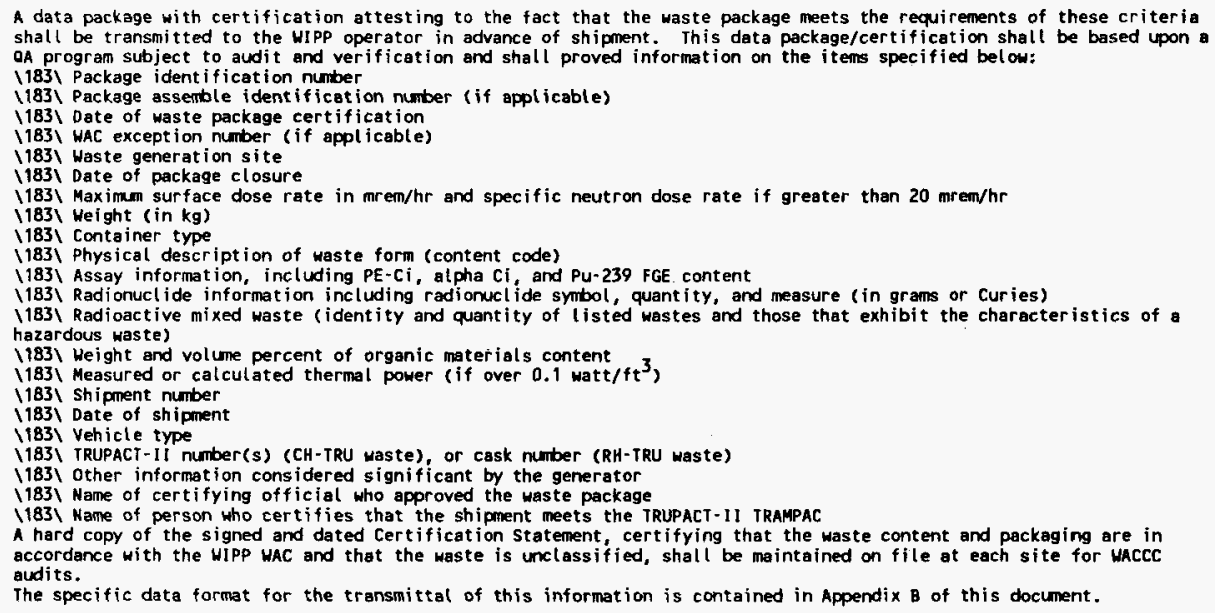 \\
\hline
\end{tabular}


Table 7-1. Constraint Definitions. (100 sheets)

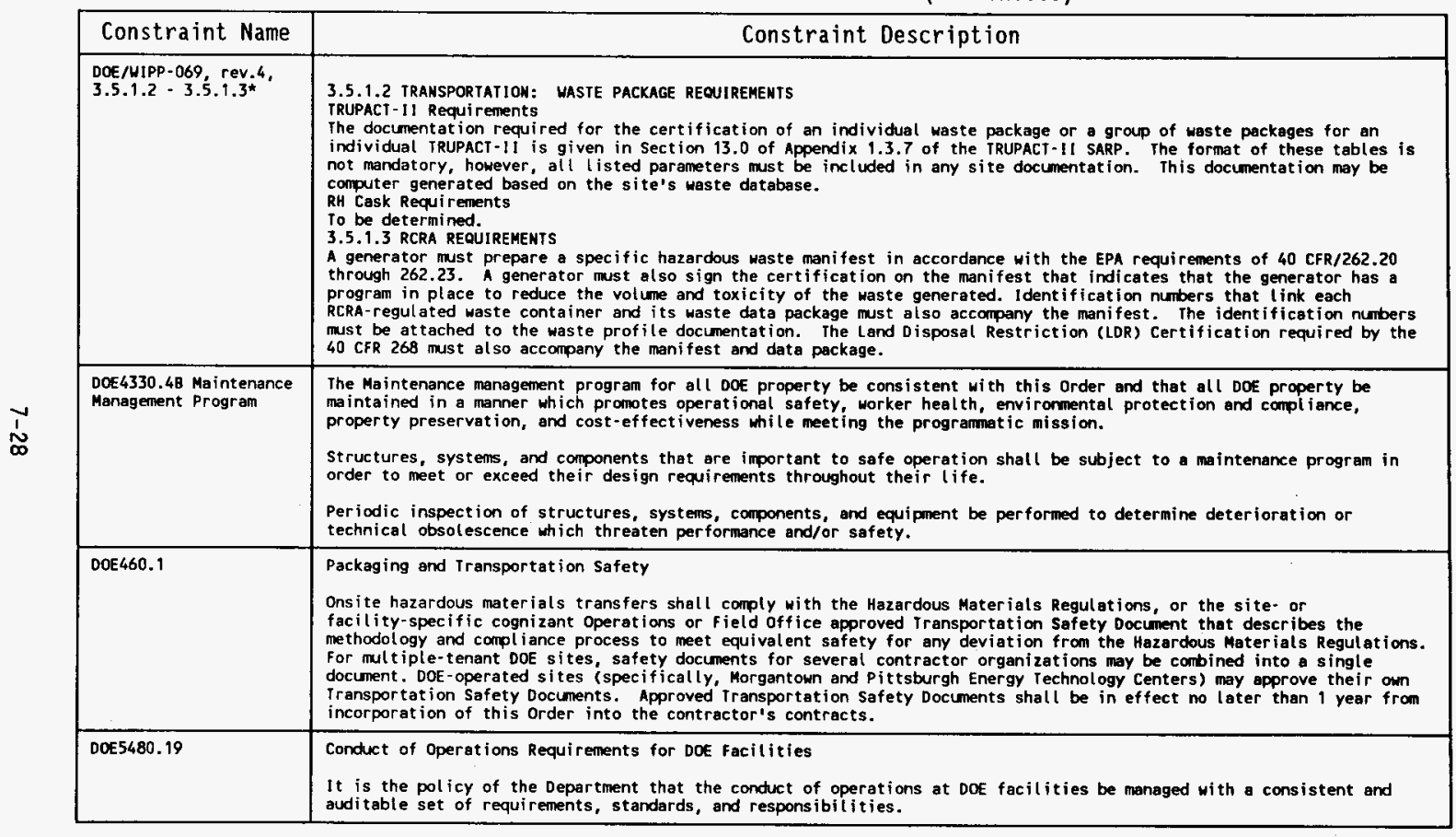


Table 7-1. Constraint Definitions. (100 sheets)

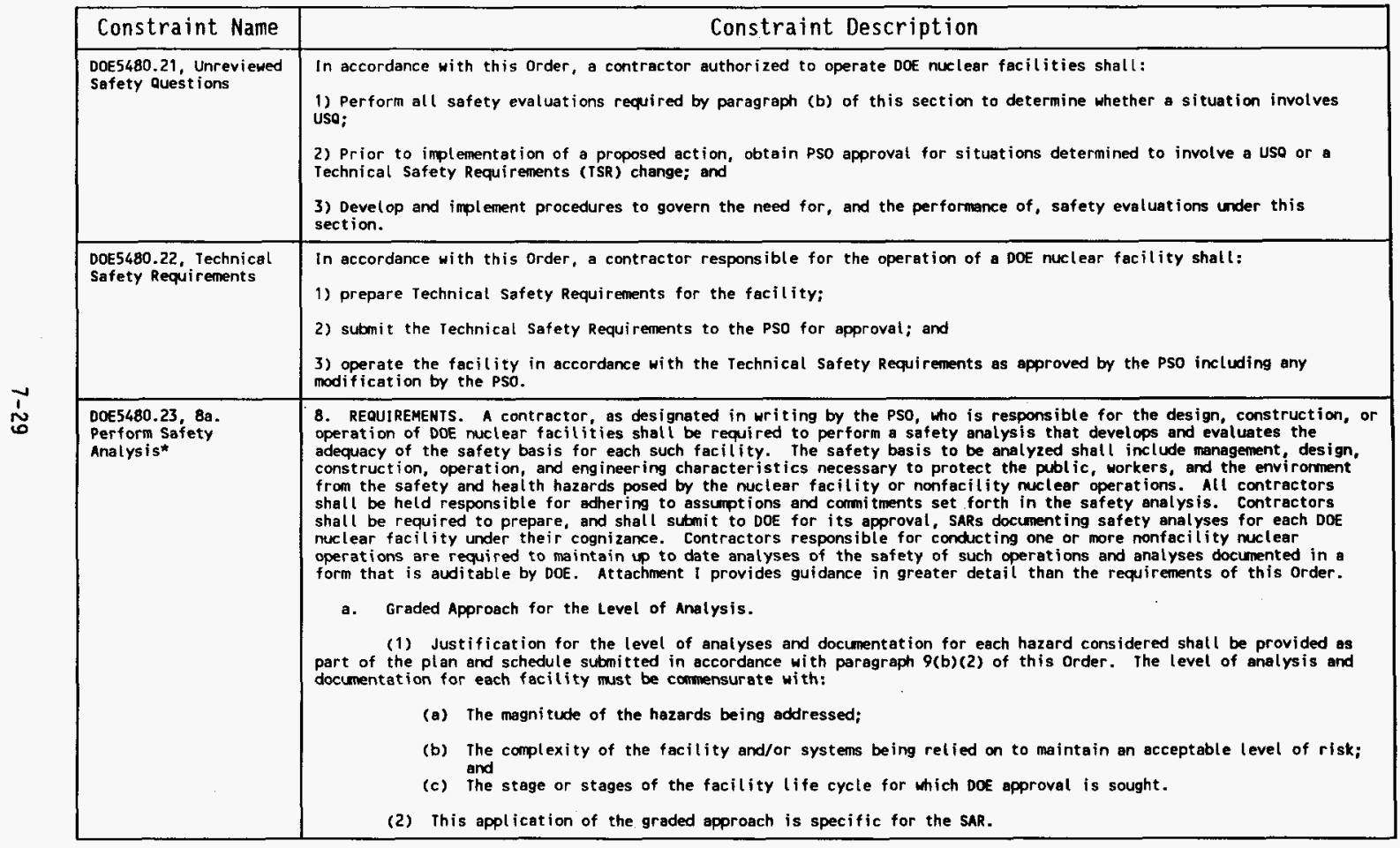


Table 7-1. Constraint Definitions. (100 sheets)

\begin{tabular}{|c|c|}
\hline Constraint Name & Constraint Description \\
\hline $\begin{array}{l}\text { DOE } 5480.23,8 \mathrm{~b} \\
\text { Perform Safety } \\
\text { Analysis* }\end{array}$ & 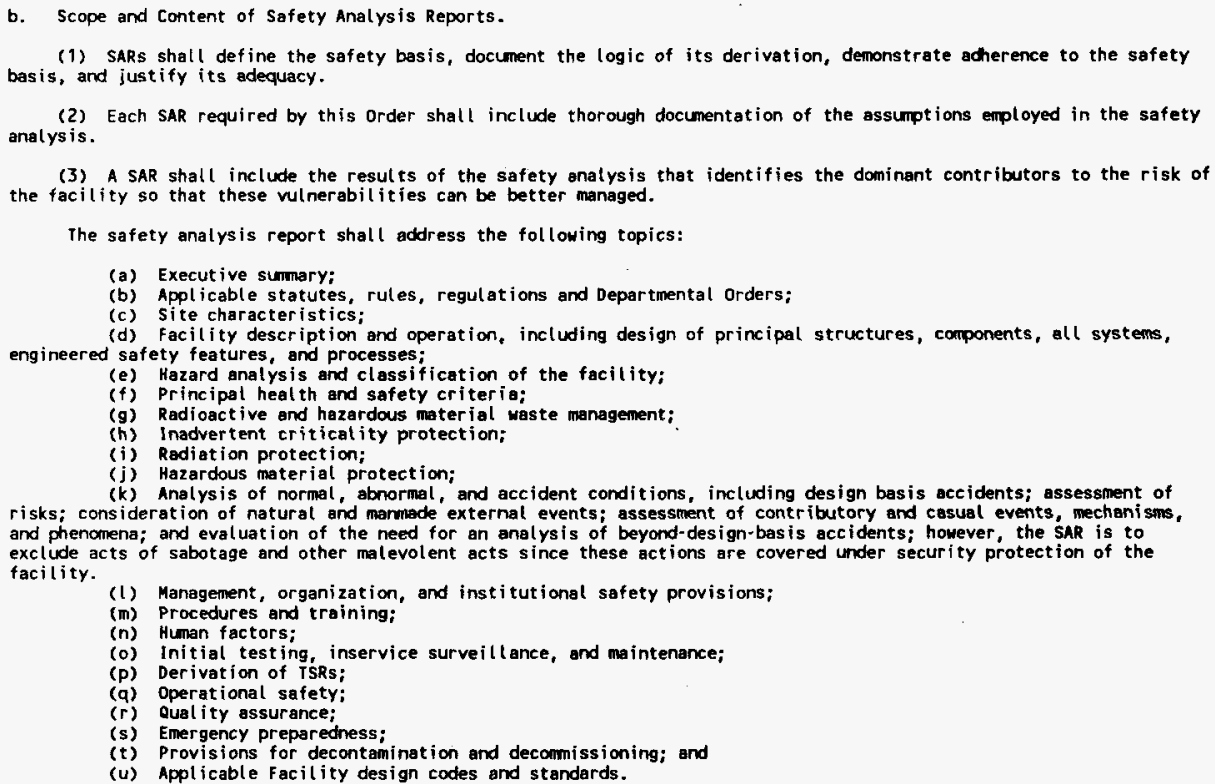 \\
\hline
\end{tabular}


Table 7-1. Constraint Definitions. (100 sheets)

\begin{tabular}{|c|c|}
\hline Constraint Name & Constraint Description \\
\hline $\begin{array}{l}\text { DOE5480.23, 8c. } \\
\text { Perform Safety } \\
\text { Analysis* }\end{array}$ & 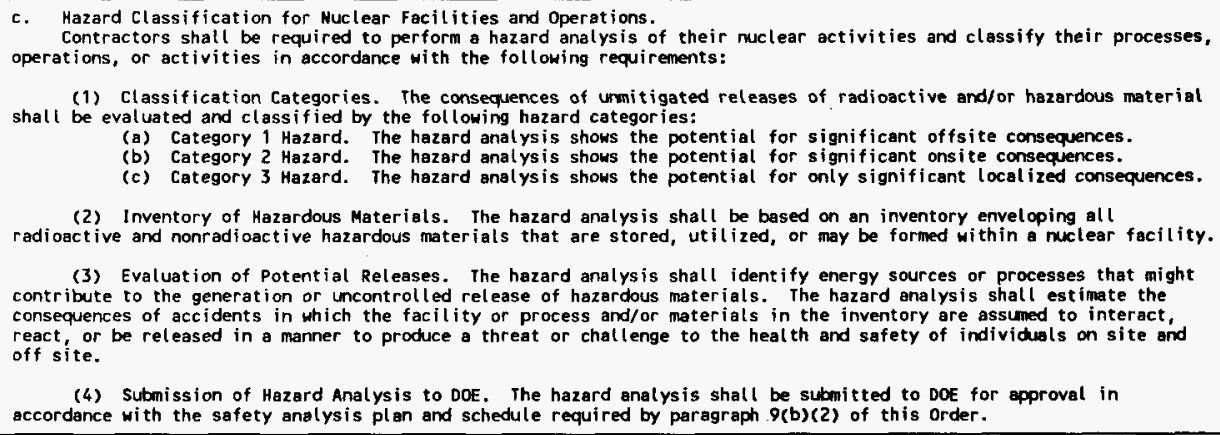 \\
\hline $\begin{array}{l}\text { Dof5480.23, 8d. } \\
\text { Perform Safety } \\
\text { Analysis* }\end{array}$ & $\begin{array}{l}\text { d. Document Control. Contractors with the primary responsibility for the design, construction, operation, or } \\
\text { decommissioning of DoE nuclear facilities must maintain such document control as may be necessary to ensure that all } \\
\text { users of sARs and their supporting documentation designated by Dof or the contractor as authorized users, including DoE } \\
\text { line management and the Department's safety oversight groups, have current editions. }\end{array}$ \\
\hline $\begin{array}{l}\text { DOE5480.4, } \\
\text { Envirormental } \\
\text { Protection, Safety and } \\
\text { Heal th Protection }\end{array}$ & 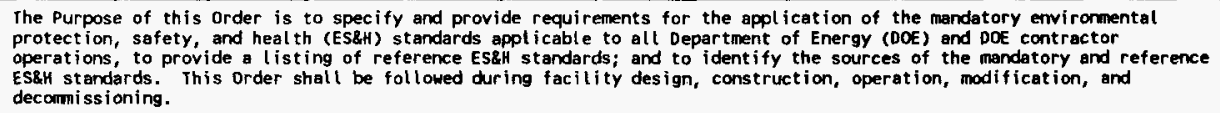 \\
\hline
\end{tabular}


Table 7-1. Constraint Definitions. (100 sheets)

\begin{tabular}{|c|c|}
\hline Constraint Name & Constraint Description \\
\hline $\begin{array}{l}\text { DOE } 5480.7 \mathrm{~A} \text {, fire } \\
\text { Protection }\end{array}$ & 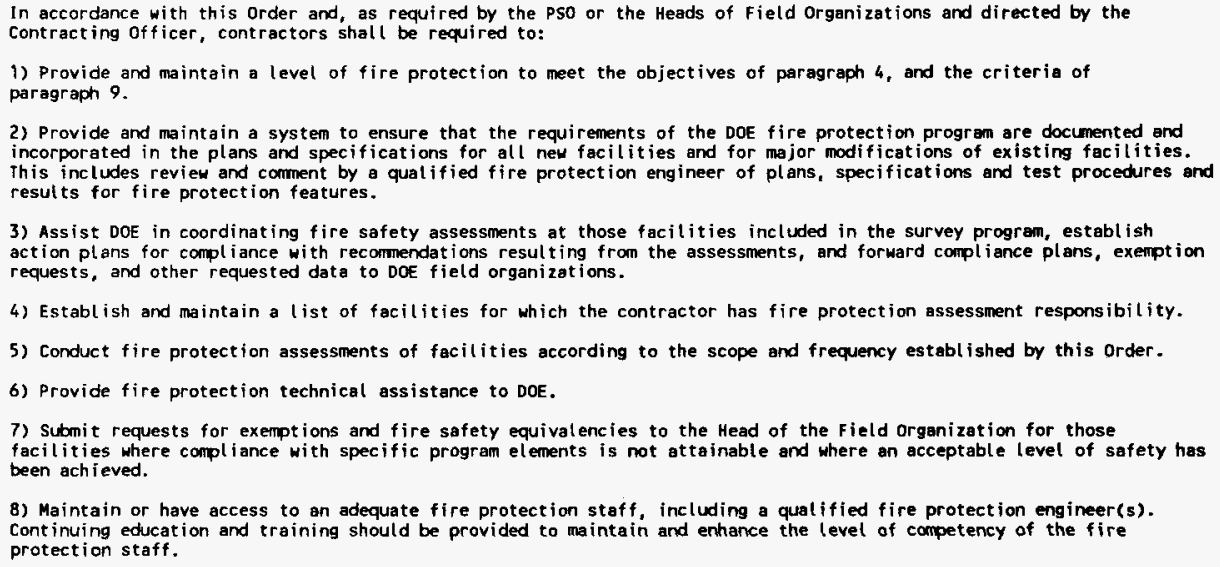 \\
\hline $\begin{array}{l}\text { DOE5820.2A, chapter } 1 \text {, } \\
\text { 3.a(1)(a) }\end{array}$ & $\begin{array}{l}\text { (a) Design objectives for new facilities will ensure protection of the public and operating persomnel from hazards } \\
\text { associated with normal high-level waste operations, accident conditions, and the effects of natural phenomena. other } \\
\text { objectives are compl iance with doe pol icies regarding nuclear safety, quality assurance, fire protection, poliution } \\
\text { control, and safeguards and security protection for high-level waste and protection of essential operations from the } \\
\text { effects of potential accidents. }\end{array}$ \\
\hline $\begin{array}{l}\text { DOE5820.2A, Chapter I, } \\
\text { 3.a(1)(b) }\end{array}$ & $\begin{array}{l}\text { (b) Designs for new storage and treatment facilities shall meet the requirements of DOE } 6430.1 \text {, applicable EM Orders and } \\
40 \text { CFR } 264 \text {. }\end{array}$ \\
\hline $\begin{array}{l}\text { DOE5820.2A, Chapter 1, } \\
3 . \mathrm{a}(1)(\mathrm{c})\end{array}$ & (c) Designs for new storage facilities shall incorporate features to facilitate retrieval capability. \\
\hline $\begin{array}{l}\text { DOE5820.2A, Chapter I, } \\
\text { 3.b(1)(b) }\end{array}$ & $\begin{array}{l}\text { (b) Waste characteristics and compatibility information shall be documented in a safety analysis report (see } \\
\text { DOE } 5481.18 \text { ) and be used as a basis for designing new facilities. }\end{array}$ \\
\hline $\begin{array}{l}\text { OOE5820.2A, chapter I, } \\
3 . \mathrm{b}(2)(\mathrm{a})\end{array}$ & $\begin{array}{l}\text { (b)(2)(a) All new high-level waste handling, transfer, end storage facilities (e.g., tanks, bins, pipelines, and } \\
\text { capsules) shall be doubly contained. }\end{array}$ \\
\hline
\end{tabular}


Table 7-1. Constraint Definitions. (100 sheets)

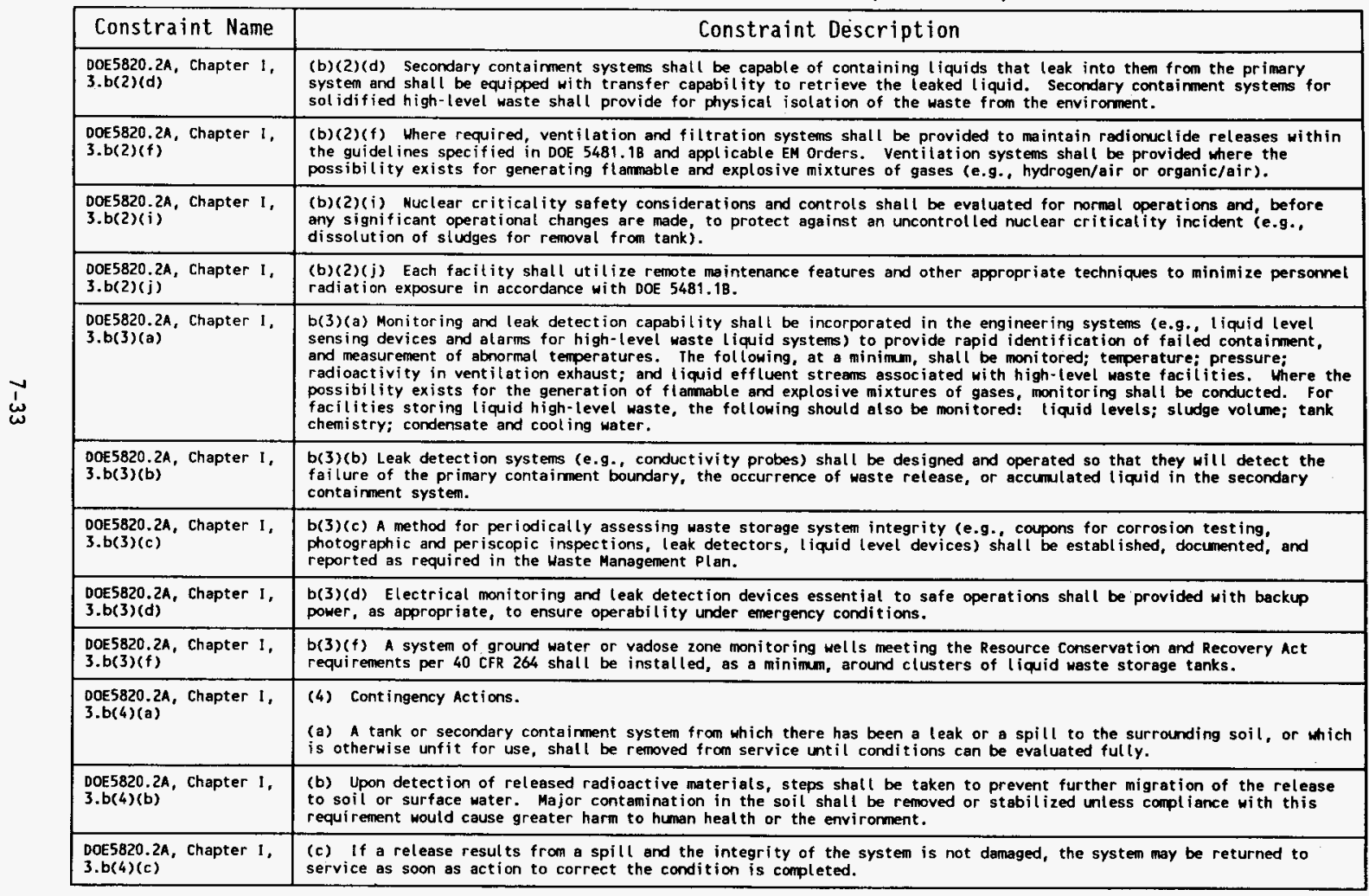


Table 7-1. Constraint Definitions. (100 sheets)

\begin{tabular}{|c|c|}
\hline Constraint Name & Constraint Description \\
\hline $\begin{array}{l}\text { DoE5820.2A, Chapter } 1 \text {, } \\
3 . b(4)(e)\end{array}$ & $\begin{array}{l}\text { (e) A schedule and procedure shall be developed for monitoring, surveillance, and cal ibration checks. The frequency of } \\
\text { these activities shall be based on the potential rate of equipment deterioration and the possibility of an environmental } \\
\text { or human heal th incident, assuming that a mal function from equipment failure or humen error is not detected between } \\
\text { checks. Schedules, procedures, and performance requirements shall be documented in the operating and maintenance } \\
\text { documentation. }\end{array}$ \\
\hline $\begin{array}{l}\text { DOE5820.2A, Chapter } 1 \text {, } \\
\text { 3.b(4)(f) }\end{array}$ & $\begin{array}{l}\text { (f) Each high-level waste facility shall have response procedures for credible emergencies, as identified in the Safety } \\
\text { Anatysis Reports. }\end{array}$ \\
\hline $\begin{array}{l}\text { DOE5820.2A, Chapter } 1 \text {, } \\
\text { 3.b(5) }\end{array}$ & $\begin{array}{l}\text { b. Storage Operations - Doubly Contained Systems. } \\
\text { (5) Training. } \\
\text { (a) Operator training and qualification standards shall be developed and an up-to-date record of training } \\
\text { (b) Worker safety training must comply with the requirements of DOE } 5480.18 \text { and applicable EM orders. }\end{array}$ \\
\hline $\begin{array}{l}\text { o0E5820.2A, chapter } 1 \text {, } \\
\text { 3.d(1)(b) }\end{array}$ & $\begin{array}{l}\text { (d)(1)(b) Interim storage for solidified high-level waste ansiting transport to the designated geologic repository shall } \\
\text { comply with applicable requirements in paragraph } 36 \text {. }\end{array}$ \\
\hline $\begin{array}{l}\text { DOE5820.2A, } \\
\text { Chapter II, } 3 . a(2)\end{array}$ & $\begin{array}{l}\text { (a)(2) The lower concentration limit for transuranic waste ( }>100 \mathrm{nci} / \mathrm{g} \text { of waste) shall apply to the contents of any } \\
\text { single waste package at the time of assay. The mass of the waste container including shielding shall not be used in } \\
\text { calculating the specific activity of the waste. }\end{array}$ \\
\hline $\begin{array}{l}\text { Bot5820.2A, } \\
\text { Chapter II, 3.a(3) }\end{array}$ & $\begin{array}{l}\text { (a)(3) Radioactive wastes with quantities of transuranic radionuclides in concentrations of } 100 \text { nci/g of maste or less } \\
\text { shall be considered to be low-level waste, and shall be managed according to the requirements of Chapter III of this } \\
\text { order. }\end{array}$ \\
\hline $\begin{array}{l}\text { DOE } 5820.2 A, \\
\text { Chapter II, 3.a(4) }\end{array}$ & $\begin{array}{l}\text { (a)(4) Mixed transuranic waste: } \\
\text { (a) Mixed transuranic waste meeting the requirements of the Haste Isolation Pilot Plant-Waste Acceptance Criteria shall } \\
\text { be sent to the Waste Isolation Pilot plant. } \\
\text { (b) The Data Package prepared by the generators for the Waste Isolation Pitot Plant shall include information on the } \\
\text { kinds and quantities of hazardous components contained in a waste package in accordance with applicable Resource } \\
\text { Conservation and Recovery Act regulations. } \\
\text { (c) The determination whether the transuranic waste exhibits any hazardous characteristics or contains listed hazardous } \\
\text { cornponents may be based on knowledge of the waste generating process when the performance of chemical analysis would } \\
\text { significantly increase the radiation hazard to personnel. }\end{array}$ \\
\hline DOE5820.2A, $3 . \mathrm{b}(2)$ & $\begin{array}{l}\text { (b)(2) Transuranic waste shall be assayed or otherwise evaluated to determine the kinds and quantities of transuranic } \\
\text { radionucl ides present prior to storage. Additionally. hazardous waste components shall be estimated or analyzed, } \\
\text { whichever is appropriate. }\end{array}$ \\
\hline
\end{tabular}


Table 7-1. Constraint Definitions. (100 sheets)

\begin{tabular}{|c|c|}
\hline Constraint Name & Constraint Description \\
\hline $\begin{array}{l}\text { DOE5B20.2A, } \\
\text { Chapter } 11,3 . c \\
(1-5)^{*}\end{array}$ & 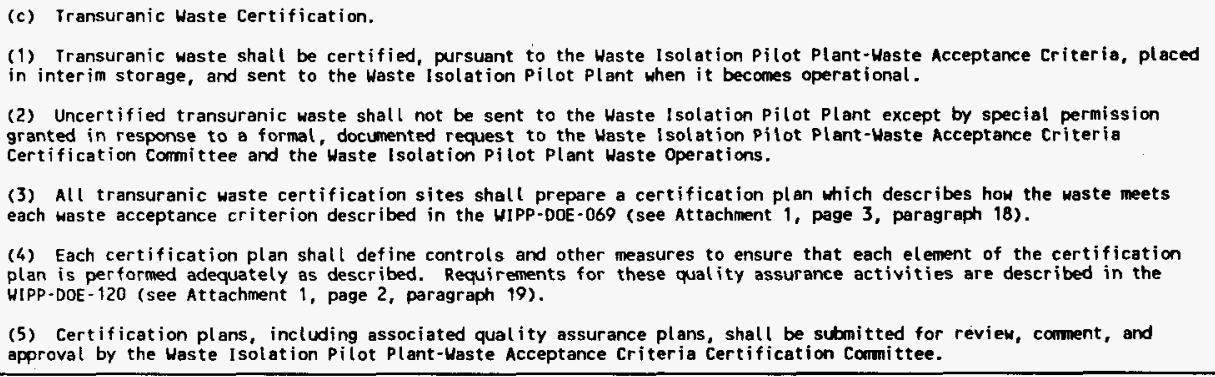 \\
\hline $\begin{array}{l}\text { DOES820.2A, } \\
\text { Chapter } 11,3 . c \\
(6-11)^{*}\end{array}$ & 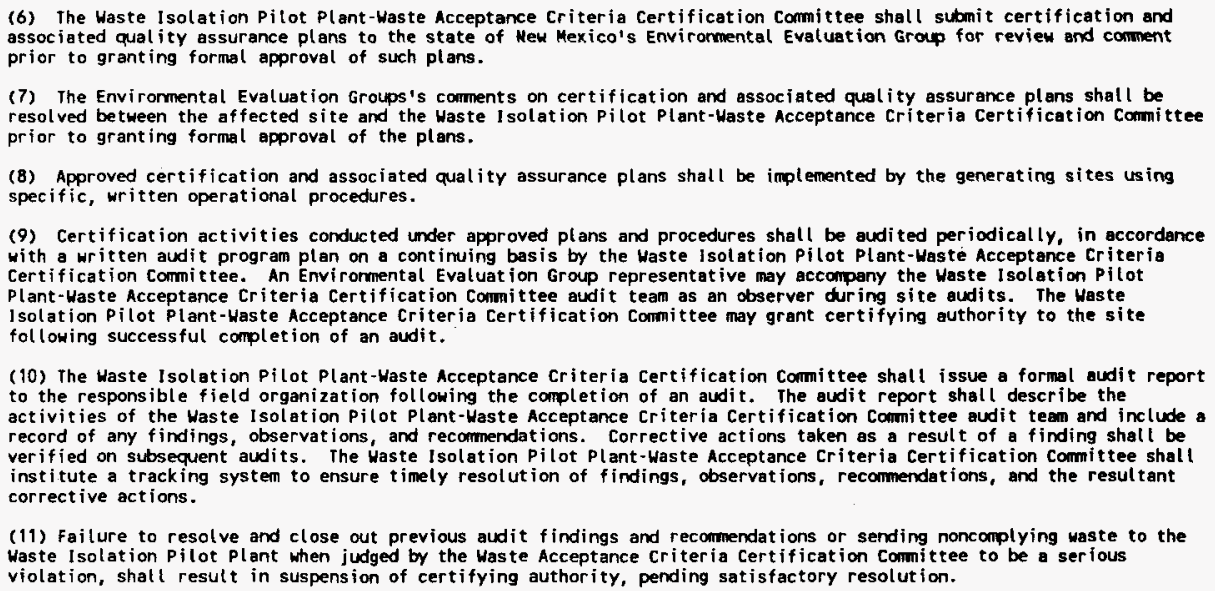 \\
\hline
\end{tabular}


Table 7-1. Constraint Definitions. (100 sheets)

\begin{tabular}{|c|c|}
\hline Constraint Name & Constraint Description \\
\hline $\begin{array}{l}\text { DOE5820.2A， } \\
\text { Chapter III, 3.d }\end{array}$ & 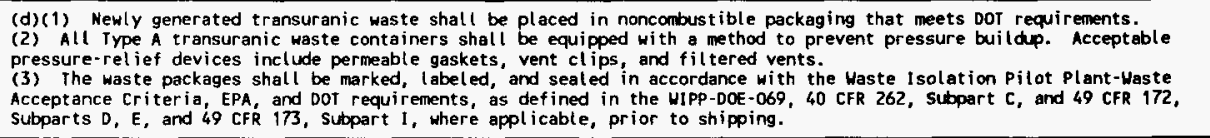 \\
\hline $\begin{array}{l}\text { DOE5820.2A, } \\
\text { Chapter } 11 \text {, 3.e }\end{array}$ & $\begin{array}{l}\text { (e) Temporary storage at Generating sites. The following activities shall be performed to ensure the safe storage of } \\
\text { transuranic wastes consistent with the requirements of applicable Resource Conservation and Recovery Act regulations: } \\
\text { (1) Transuranic waste shall be segregated or otherwise clearly identified to avcid the commingling of transuranic waste } \\
\text { streams with high-levet waste or low-level waste. } \\
\text { (2) Certified transuranic waste shall not be cormingled with noncertified transuranic waste and shall be stored in a } \\
\text { manner unlikely to alter its certification status. } \\
\text { (3) Transuranic waste in storage areas shall be protected from unauthorized access. } \\
\text { (4) Transuranic wastes in storage shall be monitored periodically to ensure that the wastes ore not releasing their } \\
\text { radioactive and/or hazardous constituents. } \\
\text { (5) Iransuranic waste storage facilities shall be designed, constructed, maintained, and operated to minimize the } \\
\text { possibitity of fire, explosion, or accidental release of radioactive and/or hazardous components of the waste to the } \\
\text { envi roment. } \\
\text { (6) Facilities which store transuranic waste shall have a contingency plan designed to minimize the adverse impacts of } \\
\text { fire, explosion, or accidental release of hazardous components of the waste to the environment. } \\
\text { (7) Iransuranic waste shall be stored in such a way so as to maintain radiation exposures as low as reasonably } \\
\text { achievable. }\end{array}$ \\
\hline $\begin{array}{l}\text { Dot5820.2A, } \\
\text { Chapter } 11,3 . f(1-2)\end{array}$ & $\begin{array}{l}\text { (f)(1) Transuranic waste shipments shall comply with the provisions of DOE and DOE regulations; pursuant to DOE } 1540.1 \text {. } \\
\text { (2) Iransuranic waste shipments by truck shall be by a DOF-control led carrier system. All transuranic waste shall be } \\
\text { transported in certified Type B packaging. }\end{array}$ \\
\hline
\end{tabular}


Table 7-1, Constraint Definitions. (100 sheets)

\begin{tabular}{|c|c|}
\hline Constraint Name & Constraint Description \\
\hline DOE5820.2A, $3 . f(1-7)^{*}$ & 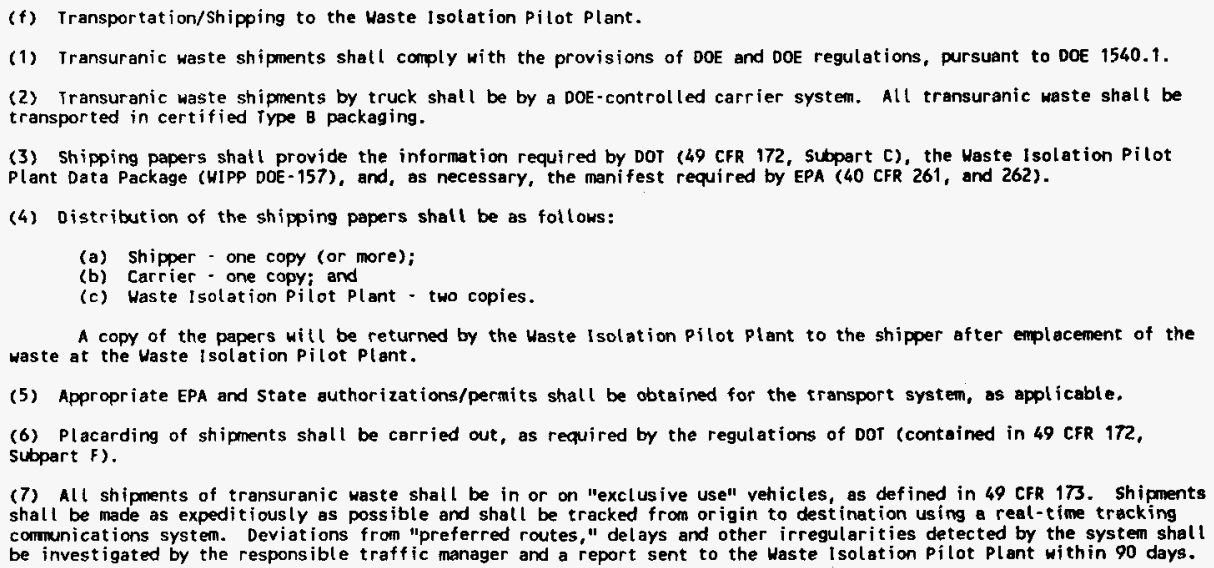 \\
\hline
\end{tabular}


Table 7-1. Constraint Definitions. (100 sheets)

\begin{tabular}{|c|c|}
\hline Constraint Name & Constraint Description \\
\hline $\begin{array}{l}\text { DOES820.2A, } \\
\text { Chapter II, 3.f(8)* }\end{array}$ & $\begin{array}{l}\text { (8) The Albuquerque operations office shall develop a transuranic waste transportation management and operations plan } \\
\text { which addresses, but is not (imited to, the following considerations: } \\
\text { (a) Cormunication between transport vehicle and traffic managenent; } \\
\text { (b) Shipment tracking in transit; } \\
\text { (c) Security; } \\
\text { (d) Emergency notification/response; } \\
\text { (e) Shipment routing; } \\
\text { (f) Shipment notification as appropriate; } \\
\text { (g) Driver training and qualifications; } \\
\text { (h) Vehicte maintenance and inspection; } \\
\text { (i) State surveillance and inspection; and } \\
\text { (j) Inspection and recertification of transport packagings. }\end{array}$ \\
\hline
\end{tabular}


Table 7-1. Constraint Definitions. (100 sheets)

\begin{tabular}{|c|c|}
\hline Constraint Name & Constraint Description \\
\hline $\begin{array}{l}\text { DOE5820.2A, } \\
\text { Chapter } 11,3.9(1-2)\end{array}$ & 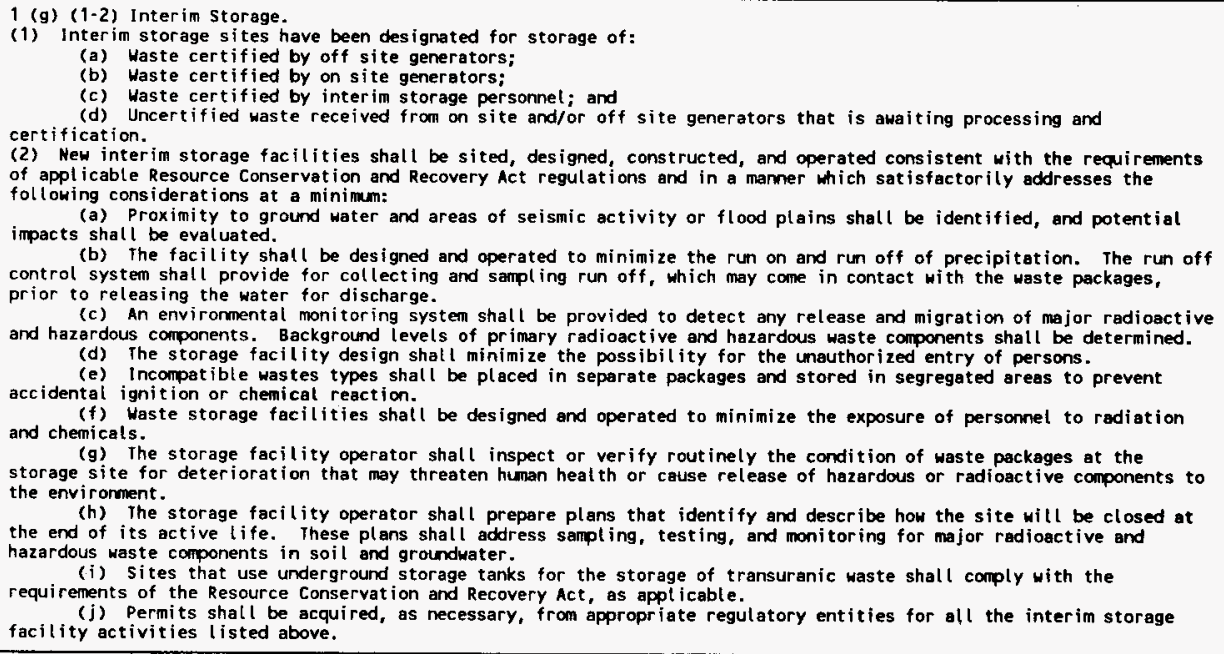 \\
\hline $\begin{array}{l}\text { DOE5820.2A, } \\
\text { Chapter II, 3.g(4) }\end{array}$ & (g)(4) Certified waste shall be stored in a manner unlikely to alter the certification of the waste package. \\
\hline $\begin{array}{l}\text { DOE5820.2A, } \\
\text { Chapter } 11,3 . g(5)\end{array}$ & $\begin{array}{l}\text { (g)(5) Operators of interim storage facilities shatl receive data package information (see Attachment } 1 \text {, page } 2 \text {, } \\
\text { paragraph } 18 \text { and } 20 \text { ) for each waste package from the generator. The operator shall store the waste generator's data and } \\
\text { shall use the data to prepare a new Data Package at the time of shipment to the Haste Isolation Pilot Plant. }\end{array}$ \\
\hline
\end{tabular}


Table 7-1. Constraint Definitions. (100 sheets)

\begin{tabular}{|c|c|}
\hline Constraint Name & Constraint Description \\
\hline $\begin{array}{l}\text { DOE5820.2A, } \\
\text { Chapter } 11,3.9(7)\end{array}$ & $\begin{array}{l}\text { (g)(7) waste that has been certified by a generator and shipped to an interim storage site shall be reshipped to the } \\
\text { Waste Isolation pilot plant by the interim storage site in the following manner: } \\
\text { (a) The generator/certifier shall be identified as the generator/certifier and shipping originator. } \\
\text { (b) The interim storage site shall be identified as the reshipper. } \\
\text { (c) The shipping originator is responsible for certifiability of the waste form, waste package content, waste } \\
\text { container procurement documentation, related oata Package information, and proper marking, labeling and placarding of the } \\
\text { shipnent. The shipping originator is responsible for any problems or discrepancies relating to the above-mentioned items } \\
\text { that may occur during shipment to or emplacement at the Waste Isolation Pilot Plant. } \\
\text { (d) The reshipper is responsible for complete data package assembly, transmittal, proper marking, labeling, } \\
\text { placarding, verifying the adequacy of the exterior condition of the container (e.g., no significant deterioration, } \\
\text { bulging) and for proper shipment loading. The reshipper shall perform radiation dose rate and contemination surveys on } \\
\text { each package. The reshipper is responsible for any problems or discrepancies involving the itens mentioned above. }\end{array}$ \\
\hline $\begin{array}{l}\text { DOE } 5820.2 A, \\
\text { Chapter } 1 \mathrm{I}, 3 . \mathrm{g}(8)\end{array}$ & $\begin{array}{l}\text { (g)(8) The interim storage site is the shipping originator for stored waste certified at that site. Agreements may need } \\
\text { to be developed between offsite waste generators and interim storage site operators/certifiers to define clearly their } \\
\text { respective responsibilities. }\end{array}$ \\
\hline $\begin{array}{l}\text { DOE5820.2A, } \\
\text { Chapter III, 3.c(1) }\end{array}$ & $\begin{array}{l}\text { c(1) Technical and administrative controls shall be directed to reducing the gross volume of waste generated and/or the } \\
\text { amount of radioactivity requiring disposal. Waste reduction efforts shall include consideration of process modification, } \\
\text { process optimization, materials substitution and decontamination. }\end{array}$ \\
\hline $\begin{array}{l}\text { DOE5820.2A, } \\
\text { Chapter } 111,3 . c(2)\end{array}$ & $\begin{array}{l}\text { c(2) Waste Generation Reduction. All DoE-fow-level waste generators shall establish auditable prograns (goals, } \\
\text { incentives, procedures, and reports) to ensure that the amount of low-level waste generated and/or shipped for disposal } \\
\text { is minimized. }\end{array}$ \\
\hline $\begin{array}{l}\text { DOE } 5820.2 A, \\
\text { Chapter } 11 \mathrm{i}, 3 . \mathrm{c}(3)\end{array}$ & $\begin{array}{l}\text { c(3) Waste Segregation. Each DOF-low-level waste generator shall separate uncontaminated waste from low-level waste to } \\
\text { facilitate cost effective treatment and disposal. }\end{array}$ \\
\hline $\begin{array}{l}\text { DOE5820.2A, } \\
\text { Chapter } 111,3 . c(4)\end{array}$ & $\begin{array}{l}\text { c(4) Waste Minimization. Each DOE-low-level waste generator preparing a design for a new process or process change } \\
\text { shal! incorporate principles into the design that will minimize the generation of low-level waste. }\end{array}$ \\
\hline
\end{tabular}


Table 7-1. Constraint Definitions. (100 sheets)

\begin{tabular}{|c|c|}
\hline Constraint Name & Constraint Description \\
\hline $\begin{array}{l}\text { DOE5820.2A, } \\
\text { Chapter ili, 3.d }\end{array}$ & $\begin{array}{l}\text { d(1) Low-level waste shall be characterized with sufficient accuracy to permit proper segregation, treatment, storage, } \\
\text { and disposal. This characterization shall ensure that, upon generation and after processing, the actual physical and } \\
\text { chemical characteristics and major radionucl ide content are recorded and known during all stages of the waste management } \\
\text { process. } \\
\text { (2) waste characterization data shall be recorded on a waste manifest, as required by paragraph } 3 \mathrm{~m} \text {, and shall include: } \\
\text { (a) The physical and chemical characteristics of the waste. } \\
\text { (b) Volume of the waste (total of waste and any sol idification or absorbent media). } \\
\text { (c) Weight of the waste (total of waste and any solidification or absorbent media). } \\
\text { (d) Major radionuclides and their concentrations. } \\
\text { (e) Packaging date, package weight, and external volume. } \\
\text { (3) The concentration of a radionuclide may be determined by direct methods or by indirect methods such as use of } \\
\text { scaling factors which relate the inferred concentration of one radionuclide to another that is measured, or radionuclide } \\
\text { material accountability, if there is reasonable assurance that the indirect methods can be correlated with actual } \\
\text { measurements. }\end{array}$ \\
\hline $\begin{array}{l}\text { DOE5820.2A, } \\
\text { Chapter IIf, 3.e(1) }\end{array}$ & $\begin{array}{l}\text { e(1) Waste shipped from one field organization to another for treatment, storage or disposal shall be done in accordance } \\
\text { with the requirements establ ished by the operations office having responsibility for operations of the receiving } \\
\text { facility. }\end{array}$ \\
\hline $\begin{array}{l}\text { DOE5820.2A, } \\
\text { Chapter III, 3.e(3) }\end{array}$ & $\begin{array}{l}\text { e(3) Generators of waste shall implement a low-level waste certification program to provide assurance that the waste } \\
\text { acceptance criteria for any low-level waste treatment, storage, or disposal facility used by the generator are met. } \\
\text { Generators and facilities receiving the waste are joint ly responsible for ensuring conpl iance with waste acceptance } \\
\text { criteria. Generators are financially responsible for actions required due to nonconformance. }\end{array}$ \\
\hline $\begin{array}{l}\text { DOE5820.2A, } \\
\text { Chapter III, 3.e(4) }\end{array}$ & $\begin{array}{l}\text { e(4) Generator low-level waste certification programs shall be subject to a periodic audit by operators facilities to } \\
\text { which the waste is sent by the generator. }\end{array}$ \\
\hline
\end{tabular}


Table 7-1. Constraint Definitions. (100 sheets)

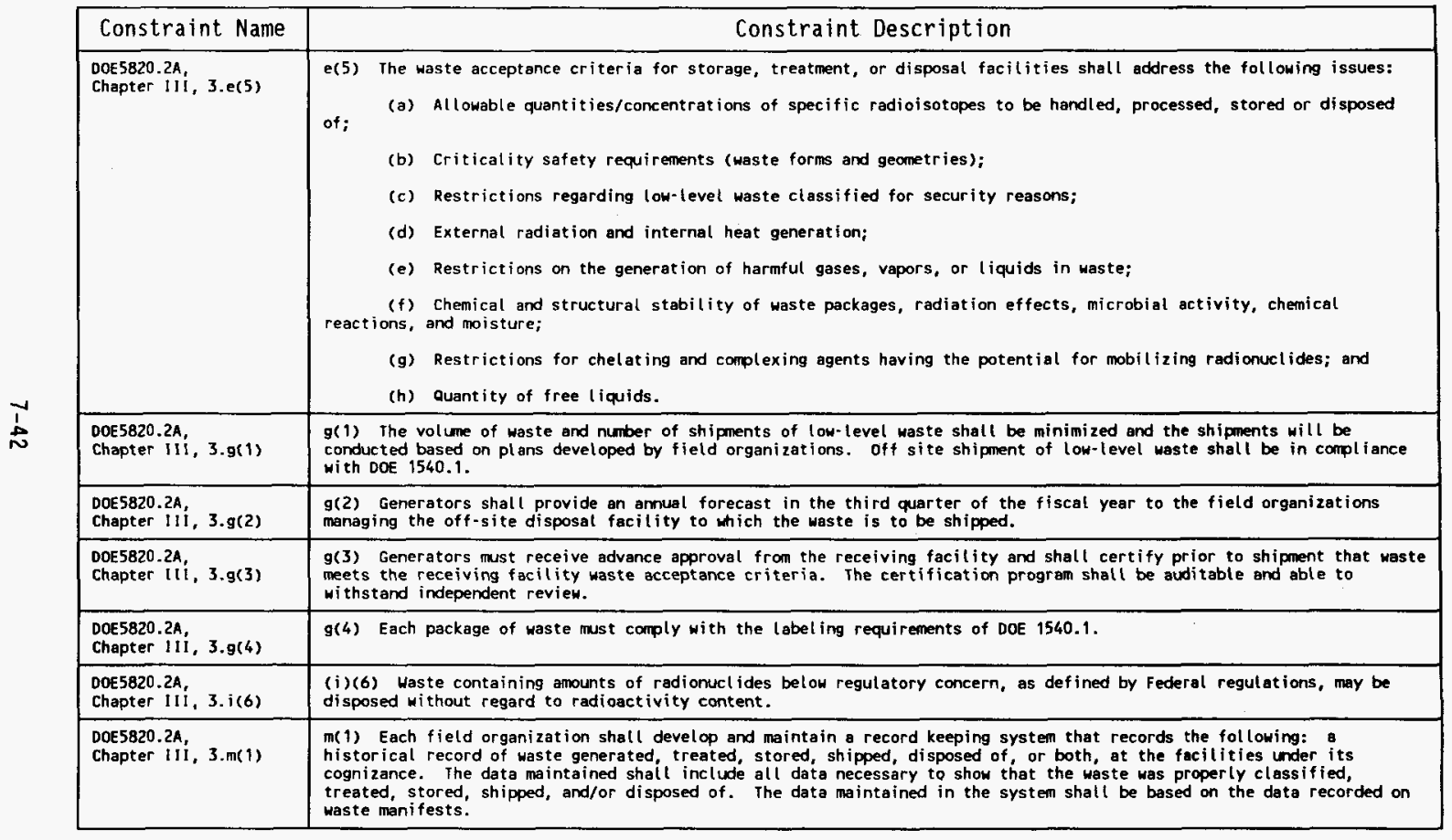


Table 7-1. Constraint Definitions. (100 sheets)

\begin{tabular}{|c|c|}
\hline Constraint Name & Constraint Description \\
\hline $\begin{array}{l}\text { DOE5820.2A, } \\
\text { Chapter } 11 \mathrm{i}, 3 . \mathrm{m}(2)\end{array}$ & $\begin{array}{l}\text { m(2) Waste Manifest. Records shall be kept and accompany each waste package from generator through final disposal. The } \\
\text { manifest shall contain data necessary to docunent the proper classification, and assist in determining proper treatment, } \\
\text { storage, and disposal of the waste. Haste manifests will be kept as permanent records. At a minimum, the following data } \\
\text { will be included: } \\
\text { (a) Waste physical and chemical characteristics, } \\
\text { (b) Quantity of each major radionucl ide present, } \\
\text { (c) Weight of the waste (total of waste and ony sol idification or absorbent media), } \\
\text { (d) volume of the waste (total of waste and any solidification or absorbent media), and } \\
\text { (e) Other data necessary to demonstrate compliance with waste acceptance criteria. }\end{array}$ \\
\hline
\end{tabular}


Table 7-1. Constraint Definitions. (100 sheets)

\begin{tabular}{|c|c|}
\hline Constraint Name & Constraint Description \\
\hline $\begin{array}{l}\text { DOE5820.2A, Chapter } V \text {, } \\
\text { 3.a }\end{array}$ & 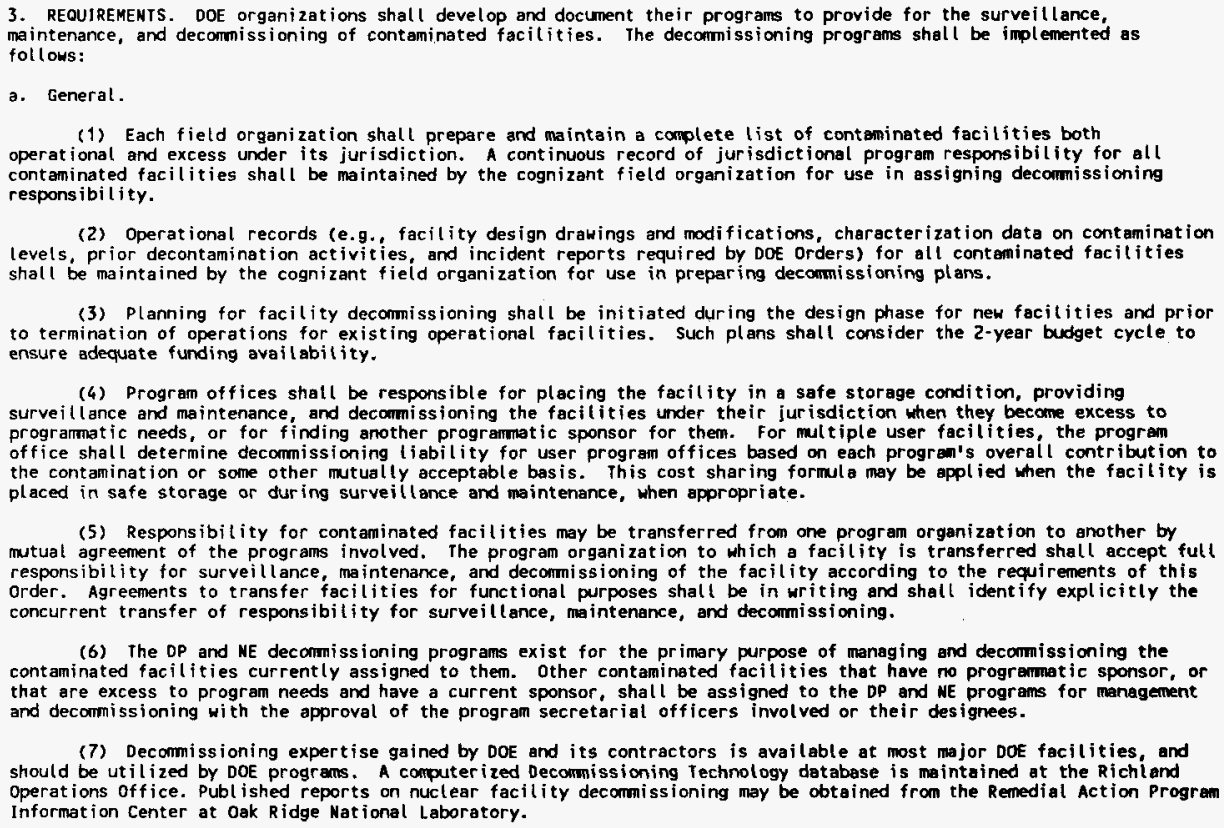 \\
\hline $\begin{array}{l}0055820.2 A, \text { Che } \\
3.3(2)\end{array}$ & $\begin{array}{l}\text { 8(2) Operational records (e.g., facility design drawings and madifications, characterization data on contamination } \\
\text { levels, prior decontamination activities, and incident reports required by oo orders) for all contaninated facilities } \\
\text { shall be maintained by the cognizant field organization for use in preparing decomissioning plans. }\end{array}$ \\
\hline
\end{tabular}


Table 7-1. Constraint Definitions. (100 sheets)

\begin{tabular}{|c|c|}
\hline Constraint Name & Constraint Description \\
\hline $\begin{array}{l}\text { DOE5B20.2A, Chapter } V \text {, } \\
\text { 3.a(5) }\end{array}$ & $\begin{array}{l}\text { a(5) Responsibility for contaminated facilities may be transferred from one program organization to another by mutual } \\
\text { arreement of the programs involved. The program organization to which a facility is transterred shatl accept futl } \\
\text { responsibility for surveillance, maintenance, and decormissioning of the facility according to the requirements of this } \\
\text { order. Agreements to transfer facilities for functional purposes shall be in writing and shall identify explicitly the } \\
\text { concurrent transfer of responsibility for surveillance, maintenance, and decomissioning. }\end{array}$ \\
\hline $\begin{array}{l}\text { DOE5820.2A, Chapter } V \text {, } \\
\text { 3.b }\end{array}$ & $\begin{array}{l}\text { Facilities in which radioactive or hazardous materials are utilized shall be designed to simplify decontamination and } \\
\text { decommissioning and/or increase the potent ial for reuse. Features and procedures that simplify and facilitate } \\
\text { decommissioning shall be ident ified during the planning and design phase based upon a proposed decomissioning method or } \\
\text { conversion to other use. }\end{array}$ \\
\hline
\end{tabular}


Table 7-1. Constraint Definitions. (100 sheets)

\begin{tabular}{|c|c|}
\hline Constraint Name & Constraint Description \\
\hline $\begin{array}{l}\text { Effluent Ireatment } \\
\text { Facility influent } \\
\text { Restrictions }\end{array}$ & $\begin{array}{l}\text { Discharge of ETF effluent is permitred for discharge to the SALOS infiltration gallery only for ETF treatment of } \\
242-A \text { Evaporator process condensate. } \\
\text { The discharge of ETF effluent to SALDS for any other ETF influent stream is prohibited unless (Washington Department of) } \\
\text { Ecology has provided the Permittee with written approval to allow an al ternative ETF influent source(s). } \\
\text { If the Permittee proposes to run a different influent source(s) (other than } 242-A \text { evaporator condensate) through ETF, a } \\
\text { characterization study must be sent to Ecology for approval, which includes: } \\
\text { 1. A listing of all chemical constituents of concern which exist in the proposed influent source(s), along with expected } \\
\text { range of concentration of each component. } \\
\text { 2. Engineer ing study results which show that ETF can adequately process the proposed influent source(s) such that } \\
\text { volation of this permit will not occur and water quality violations related to any constituents not listed in the } \\
\text { original permit will not occur. } \\
\text { 3. Information indicating acceptance of the proposed influent stream relating to RCRA and state Hazardous waste Law and } \\
\text { ai other applicable authorities' acceptance of the proposed source(s). } \\
\text { 4. A demonstration that the ETf treatment process constitutes aAT/AKART for the proposed influent source(s). }\end{array}$ \\
\hline EM-WAPS 1.1 & $\begin{array}{l}\text { The waste form is borosilicate waste glass. } \\
\text { NotE: This specification is in conflict with THRS basel ine requirements. The ThRS basel ine considers the possible use } \\
\text { of other glass compositions, e.g., aluminosilicate glass. (See } 4.204 \text { Issue } 1 . \text { ) }\end{array}$ \\
\hline EM-HAPS 2.2 & $\begin{array}{l}\text { The canister fabrication and closure methods shall be identified in the WCP. The outermost closure shall be leaktight to } \\
1 \times 10-4 \text { atm-cc/s hel ium. The method for demonstrating compliance shall be described by the producer in the WCP. The woR } \\
\text { shatl provide evidence that the canister fabrication and closure methods ure capable of complying with the leaktightness } \\
\text { criterion. Compliance during production shall be documented in the Production Records. }\end{array}$ \\
\hline EM-NAPS 2.3 .1 & $\begin{array}{l}\text { The producer shall assign a unique alphanumeric identifier to label each outermost canister that is produced. This label } \\
\text { shall appear on the canistered waste form and on all documentation pert inent to that particular canistered waste form. }\end{array}$ \\
\hline EM-WAPS 2.3 .2 & $\begin{array}{l}\text { Each canister shall be labeled in two locations: one visible from the top and one from the side of the canister. The } \\
\text { identification code shall be printed in a type size of at least } 92 \text { points using a sans serif type face. A proposed } \\
\text { layout shatl be provided in the HCP. Labels shall be applied to the exterior of the outermost canister and shall not } \\
\text { cause the dimensional limits (Specification } 3 \text {. } 11 \text { ) to be exceeded. } \\
\text { The label shall be designed to be legible after filling and storage at the producers facility and shipment to the } \\
\text { repository. The label shatl be an integral part of the canister and shall not impair the integrity of the canister. }\end{array}$ \\
\hline EM-HAPS 3.1 & $\begin{array}{l}\text { The producer shall ensure that the canistered waste form does not contain detectable amounts of free liquids. The } \\
\text { producer shall describe the method of compliance in the KCP and provide documentation of the obility to comply, and of } \\
\text { the detection limits, in the WOR. }\end{array}$ \\
\hline
\end{tabular}


WHC-SD-WM-FRD-027 Rev. 0

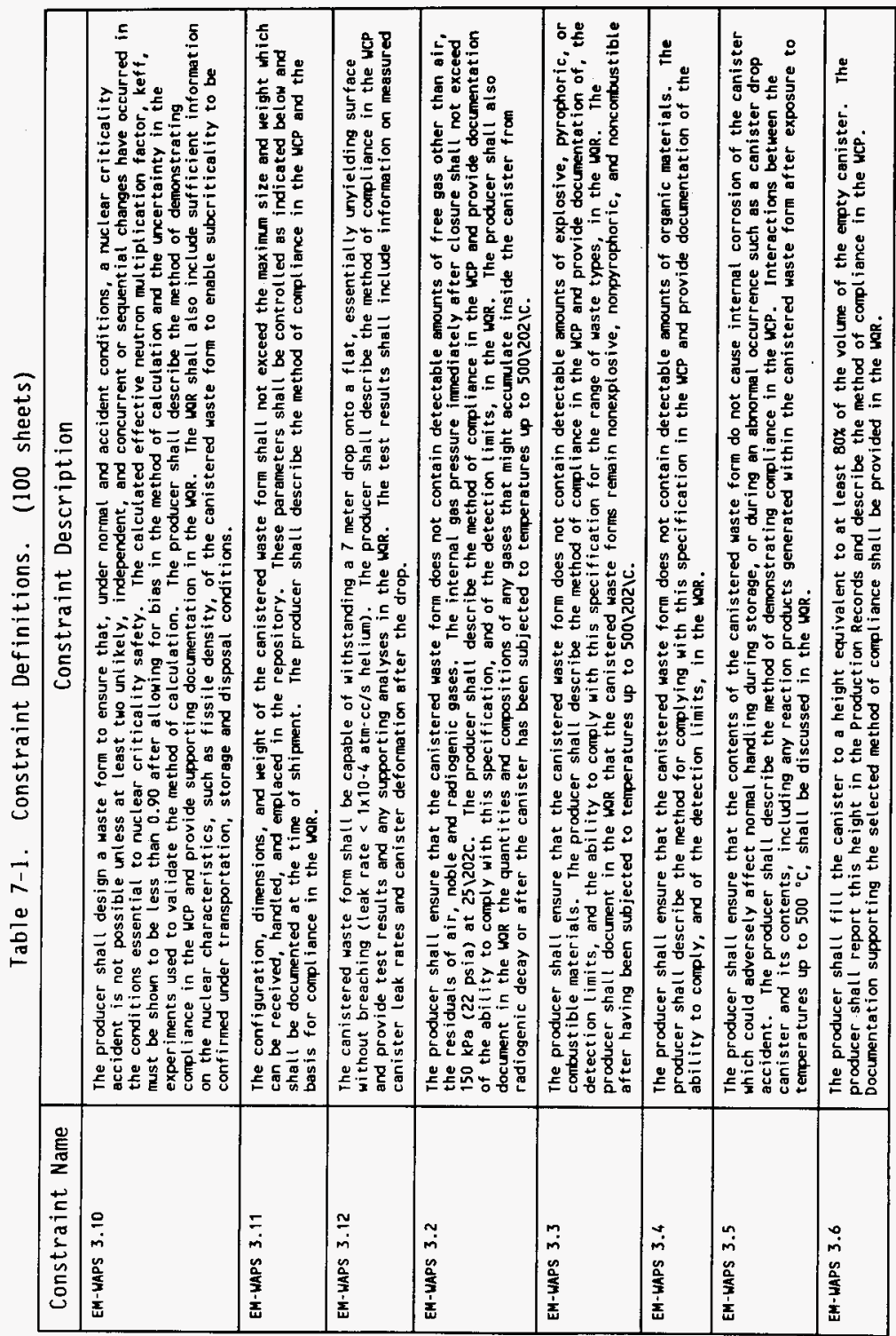


Table 7-1. Constraint Definitions. (100 sheets)

\begin{tabular}{|c|c|}
\hline Constraint Name & Constraint Description \\
\hline EM-WAPS 3.7 & $\begin{array}{l}\text { The level of removable radioactive contamination on all external surfaces of each canistered waste form shall not exceed } \\
\text { the following limits at the time of shipment: } \\
\text { Alpha radiation: } 220 \mathrm{dpm} / 100 \mathrm{~cm}^{2} \\
\text { Beta and Gamma radiation: } 2200 \mathrm{dpm} / 100 \mathrm{~cm}^{2} \\
\text { in addition, the producer shall visually inspect each canistered waste form and remove visible waste glass from the } \\
\text { exterior before shipment. The producer shall describe the method of compliance in the wcp and provide contamination } \\
\text { level results in the Storage and Shipping Records. }\end{array}$ \\
\hline EM-WAPS 3.8 .1 & $\begin{array}{l}\text { The producer shall document in the war the expected thermal output of the canistered waste forms and the range of } \\
\text { expected variation for each waste type, indexed to the year } 2015 \text {. The method to be used for demonstrating compl iance } \\
\text { shall be described by the producer in the WCP. Projections for compositions not available for reporting in the initial } \\
\text { woR shall be included in an addendum to the wor. }\end{array}$ \\
\hline EM-WAPS 3.8 .2 & $\begin{array}{l}\text { The producer shall report in the Storage and Shipping Records the est imated heat generation rate for each canistered } \\
\text { waste form. The producer shall describe the method for compl iance in the WCP. }\end{array}$ \\
\hline EM-NAPS 3.9 .1 & $\begin{array}{l}\text { The producer shall report in the WaR the expected values and the range of expected variation for both gamma and neutron } \\
\text { dose rates indexed to the year } 2015 \text {. The producer shall describe the riethod for demonstrating compliance in the UCP. }\end{array}$ \\
\hline EM-WAPS 3.9 .2 & $\begin{array}{l}\text { The producer shall provide in the Storage and Shipping Records either the calculated or measured values for both gamme } \\
\text { and neutron dose rates at the time of shipment for each canistered waste form. The producer shall describe the method of } \\
\text { compl iance in the WCP. }\end{array}$ \\
\hline SEN-35-91 & 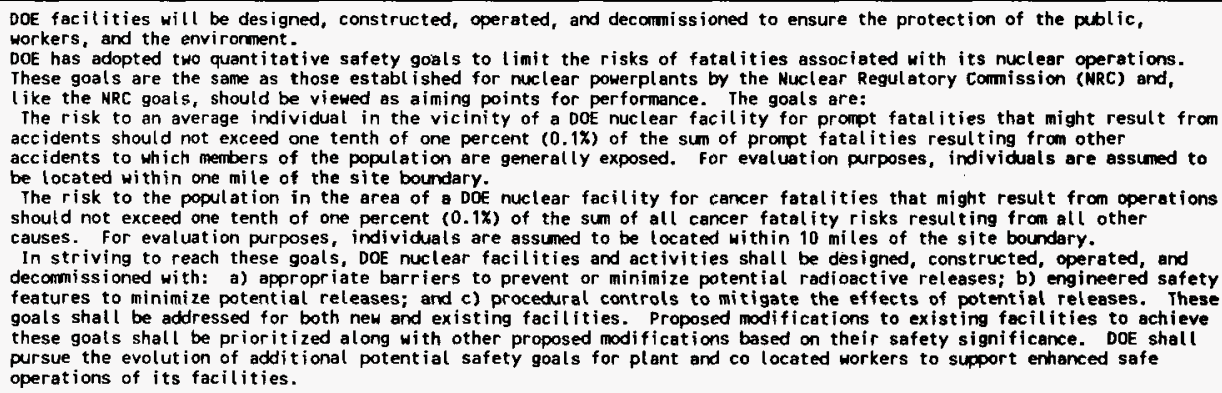 \\
\hline $\begin{array}{l}\text { Swop Permit } 4502 \text { and } \\
\text { Fact Sheet }\end{array}$ & $\begin{array}{l}\text { Comply with the requirements of the State Waste Discharge Permit \#st } 4502 \text { for } 200 \text { Area Treated Effluent Disposal } \\
\text { Facility. }\end{array}$ \\
\hline HAC $173-303-630(1)$ & $\begin{array}{l}\text { (1) The regulations in this section apply to owners and operators of all dangerous waste facilities that store containers } \\
\text { of dangerous waste. }\end{array}$ \\
\hline
\end{tabular}


Table 7-1. Constraint Definitions. (100 sheets)

\begin{tabular}{|c|c|}
\hline Constraint Name & Constraint Description \\
\hline WAC173-303-630(6) & $\begin{array}{l}\text { (6) At least weekly, the owner or operator must inspect areas where containers are stored, looking for leaking } \\
\text { containers and for deterioration of containers and the containment system caused by corrosion, deterioration, or other } \\
\text { factors. }\end{array}$ \\
\hline HaC173-303-630(8) & 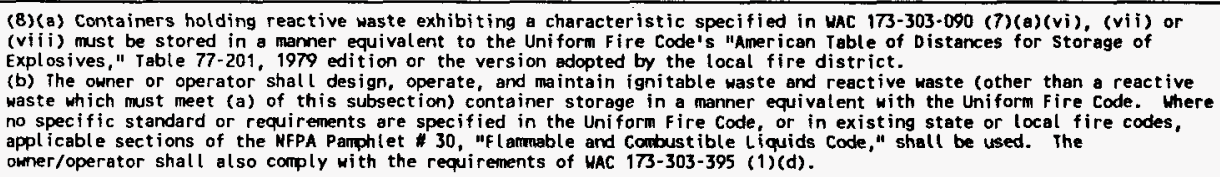 \\
\hline
\end{tabular}


Table 7-1. Constraint Definitions. (100 sheets)

\begin{tabular}{|c|c|}
\hline Constraint Name & Constraint Description \\
\hline MAC $173-303-645(8)(a-c)$ & 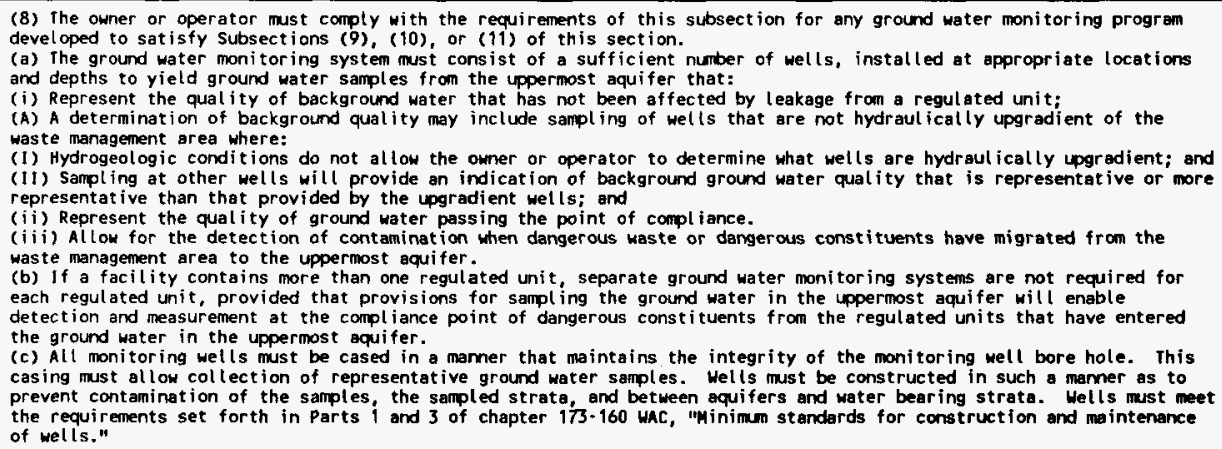 \\
\hline WAC $173-303-645(9)(a-c)$ & 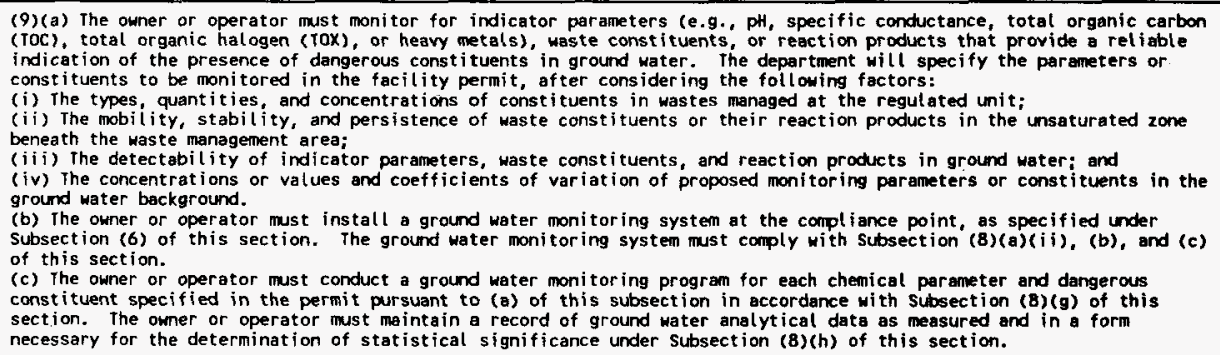 \\
\hline
\end{tabular}


Table 7-1. Constraint Definitions. (100 sheets)

\begin{tabular}{|c|c|}
\hline Constraint Name & Constraint Description \\
\hline UAC173-460-010 & 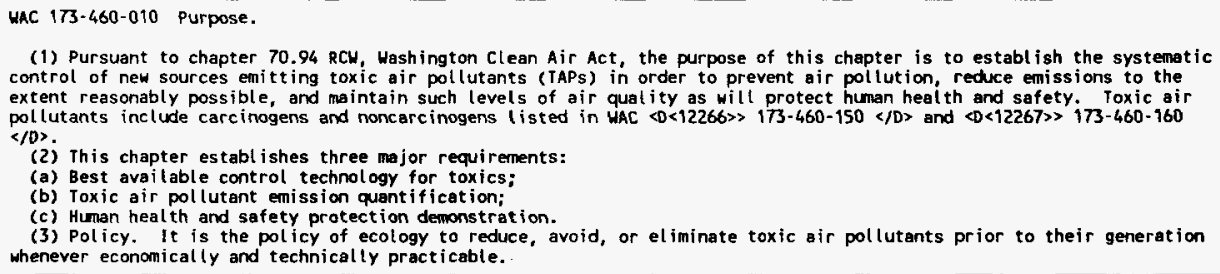 \\
\hline & 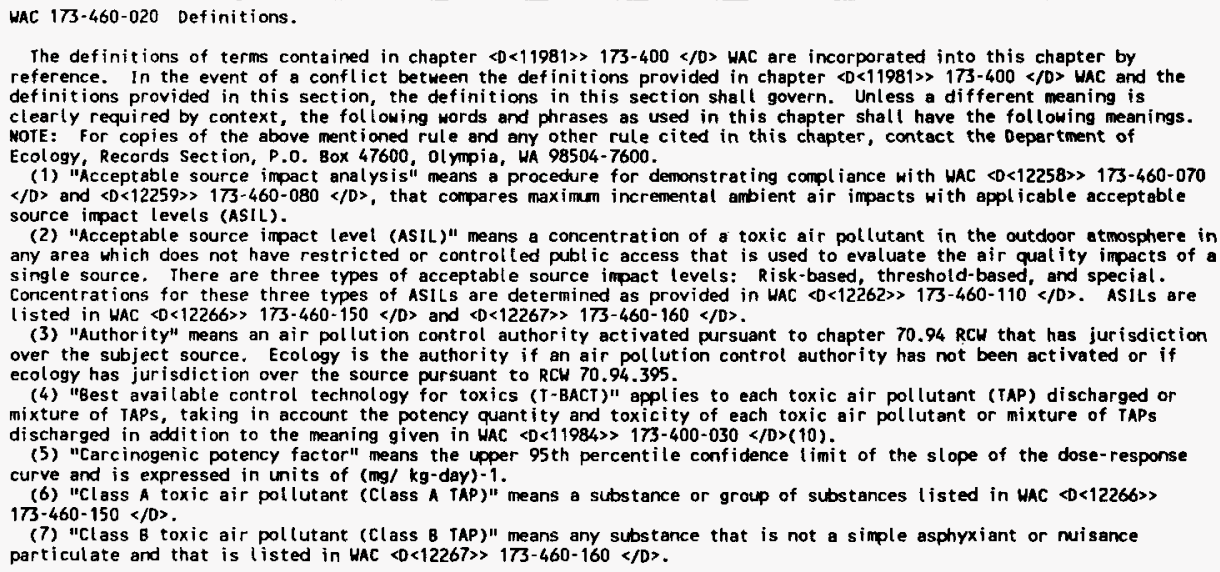 \\
\hline
\end{tabular}


Table 7-1. Constraint Definitions. (100 sheets)

\begin{tabular}{|c|c|c|}
\hline & Constraint Name & Constraint Description \\
\hline . & $\begin{array}{l}\text { HAC173-460-020 } \\
(16-21)^{*}\end{array}$ & 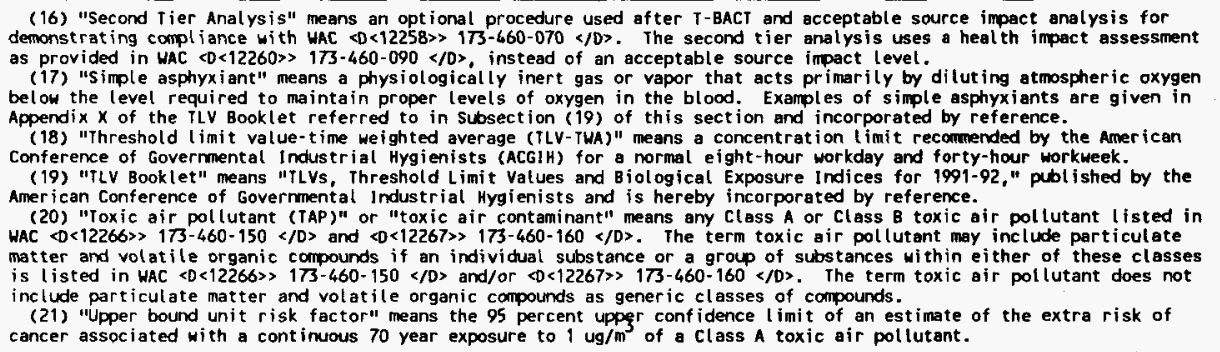 \\
\hline & $\begin{array}{l}\text { WAC } 173-460-020 \\
(8-15)^{*}\end{array}$ & 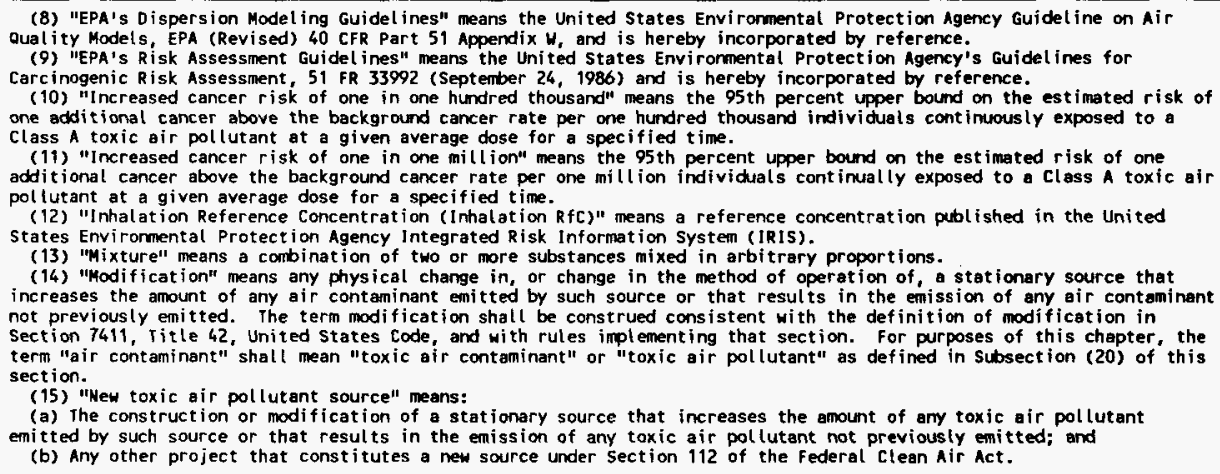 \\
\hline
\end{tabular}


Table 7-1. Constraint Definitions. (100 sheets)

\begin{tabular}{|c|c|}
\hline Constraint Name & Constraint Description \\
\hline WAC173-460-030 (1)* & 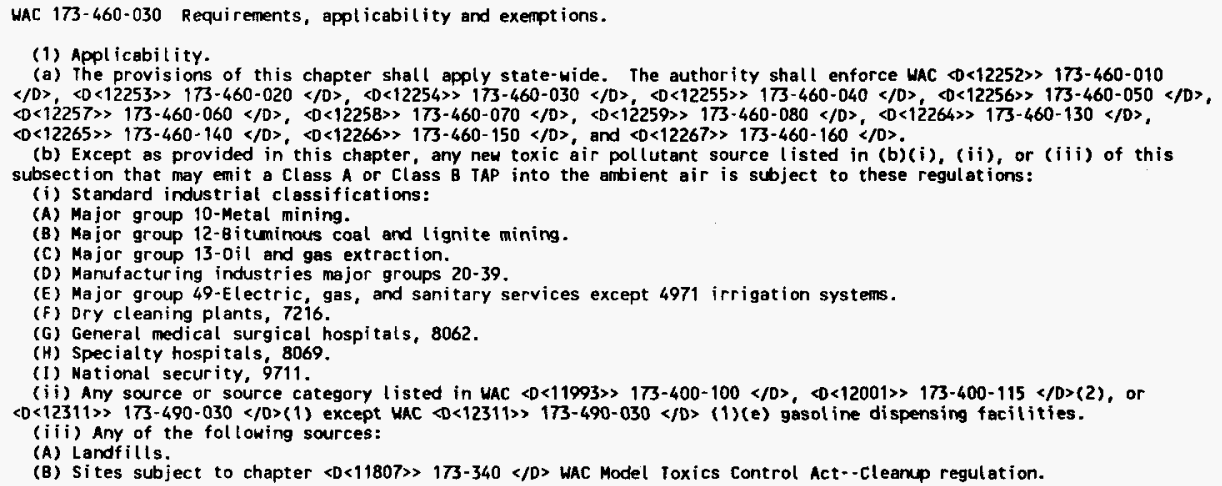 \\
\hline HAC173-460-030(2)* & 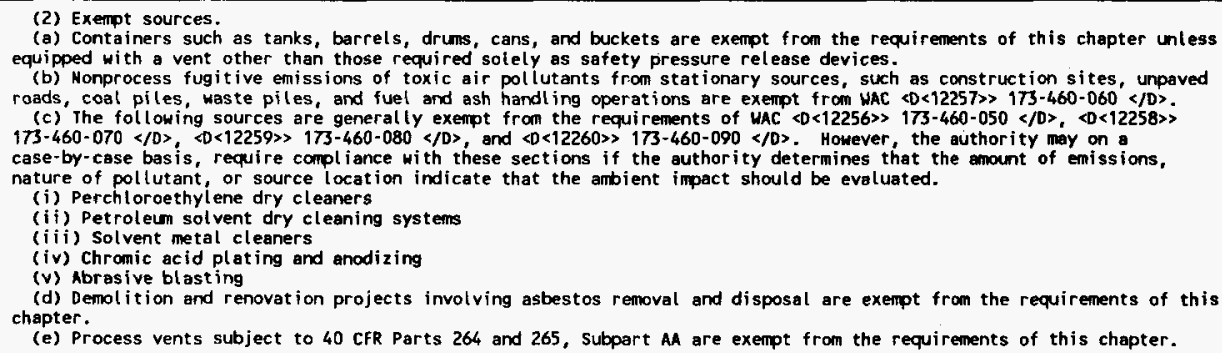 \\
\hline
\end{tabular}


Table 7-1. Constraint Definitions. (100 sheets)

\begin{tabular}{|c|c|}
\hline Constraint Name & Constraint Description \\
\hline $\begin{array}{l}\text { WAC173-460-040 } \\
(1-3)^{*}\end{array}$ & 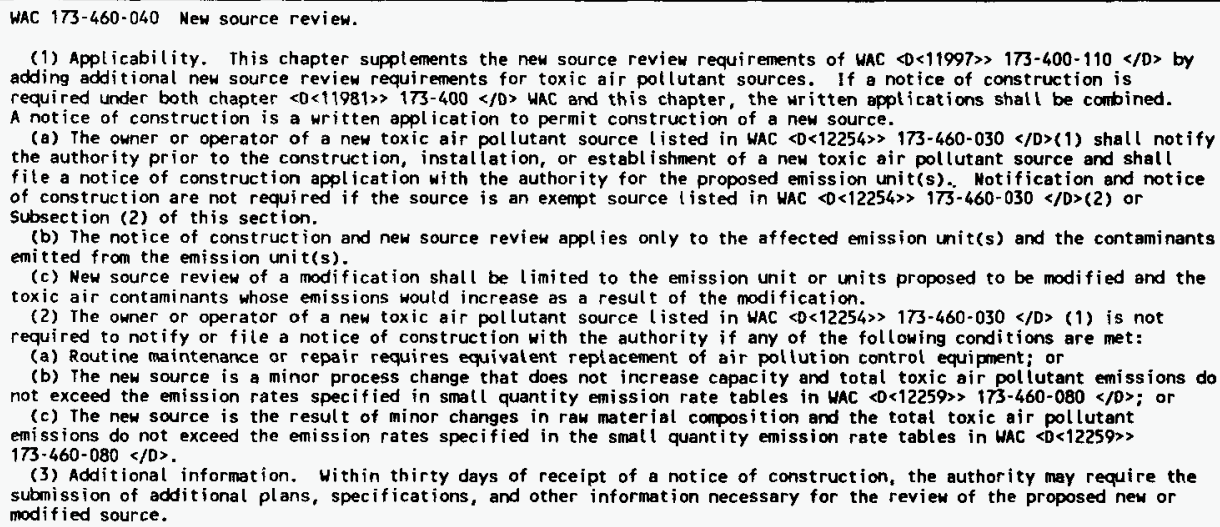 \\
\hline
\end{tabular}


Table 7-1. Constraint Definitions. (100 sheets)

\begin{tabular}{|c|c|}
\hline Constraint Name & Constraint Description \\
\hline $\begin{array}{l}\text { HAC } 173-460-040 \\
(4 \cdot 8) *\end{array}$ & 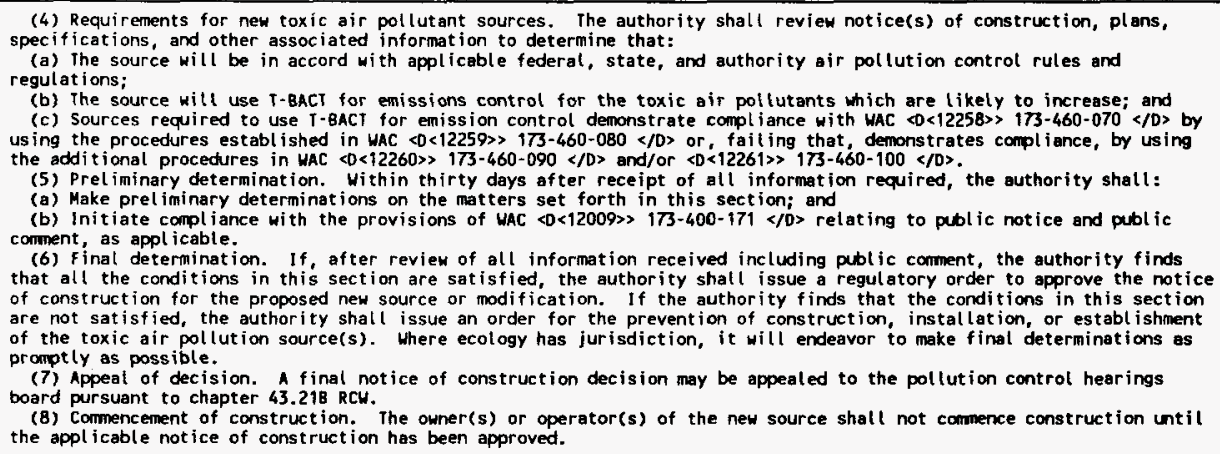 \\
\hline
\end{tabular}


Table 7-1. Constraint Definitions. (100 sheets)

\begin{tabular}{|c|c|}
\hline Constraint Name & Constraint Description \\
\hline $\begin{array}{l}\text { WaC } 173-460-050 \\
(1-3)^{*}\end{array}$ & 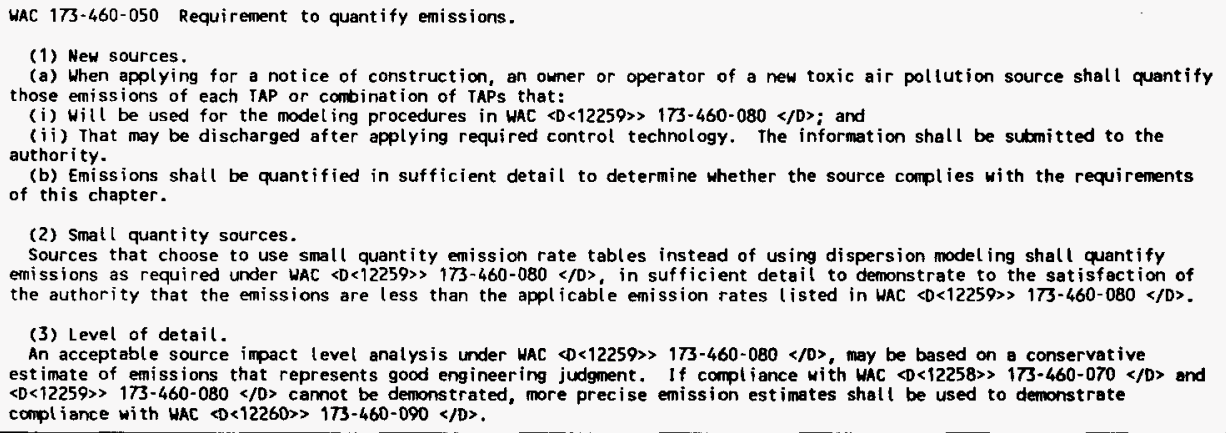 \\
\hline $\begin{array}{l}\operatorname{HAC} 173-460-050 \\
(4 a-4 c)^{*}\end{array}$ & 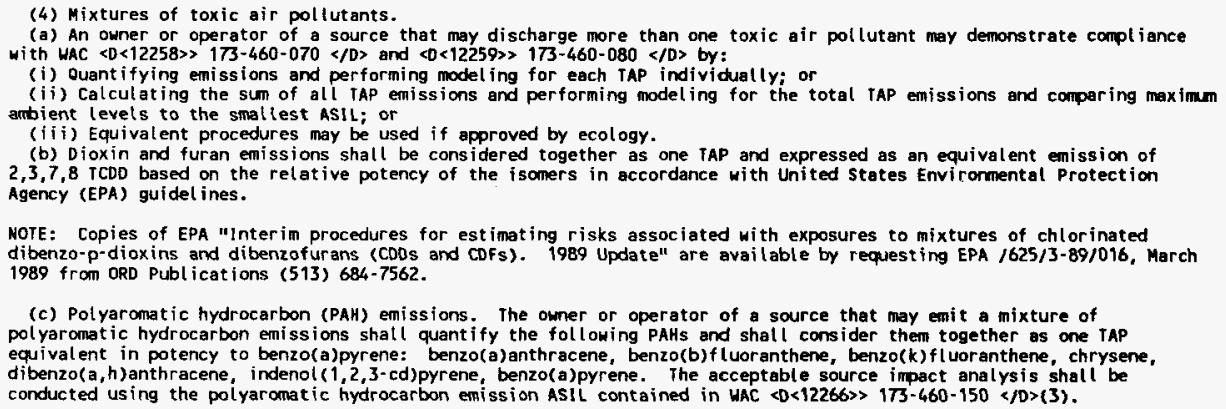 \\
\hline
\end{tabular}


Table 7-1. Constraint Definitions. (100 sheets)

\begin{tabular}{|c|c|}
\hline Constraint Name & Constraint Description \\
\hline WAC173-460-050 (4d)* & 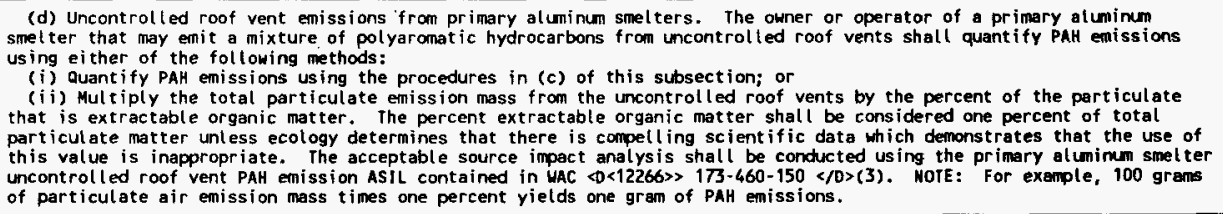 \\
\hline $\begin{array}{l}\text { WAC } 173-460-060 \\
(1-2)^{\star}\end{array}$ & 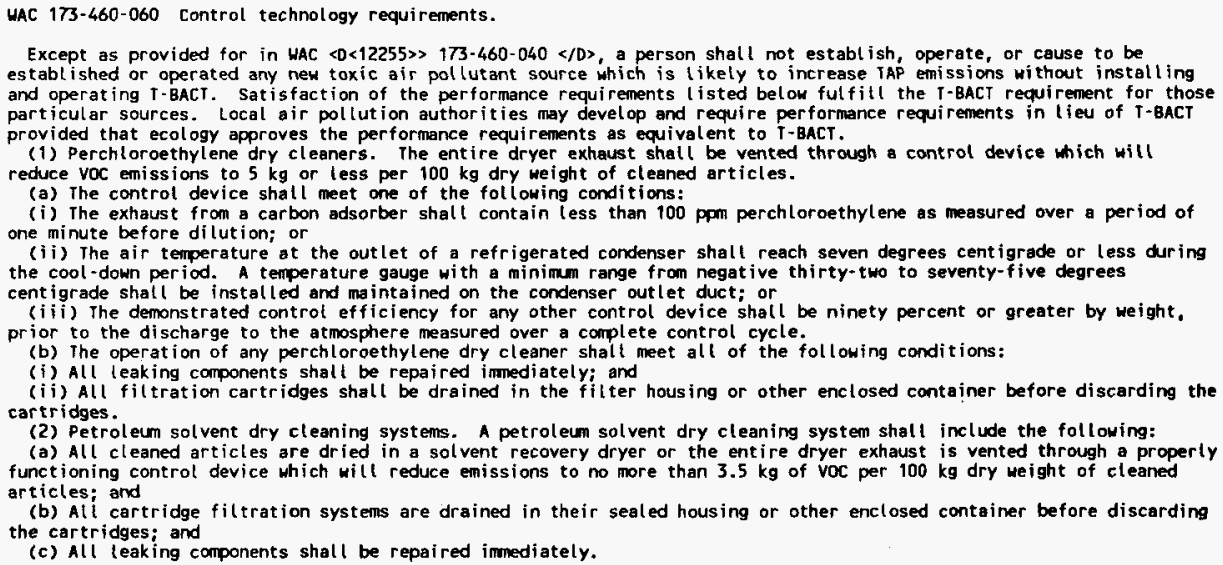 \\
\hline
\end{tabular}


Table 7-1. Constraint Definitions. (100 sheets)

\begin{tabular}{|c|c|}
\hline Constraint Name & Constraint Description \\
\hline $\begin{array}{l}\text { UaC173-460-060 } \\
(3-4)^{*}\end{array}$ & 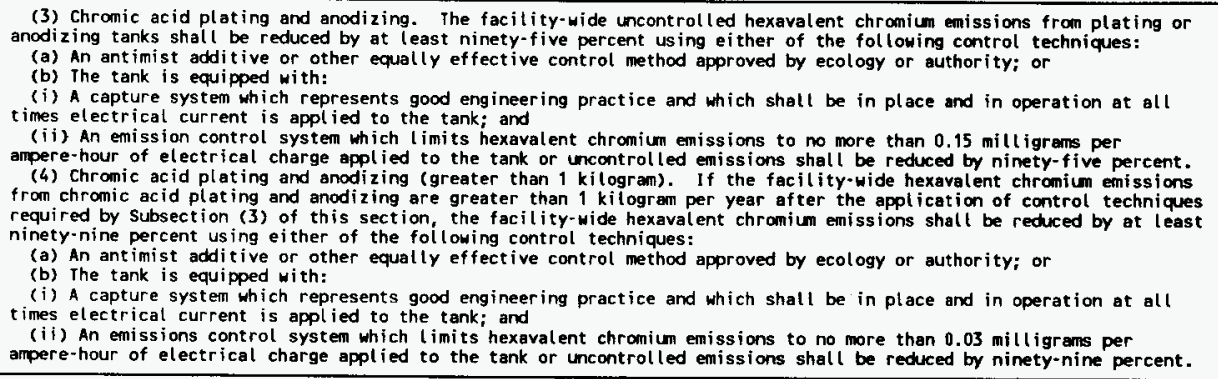 \\
\hline $\begin{array}{l}\text { MAc173-460-060 } \\
(5 a-5 b)^{*}\end{array}$ & 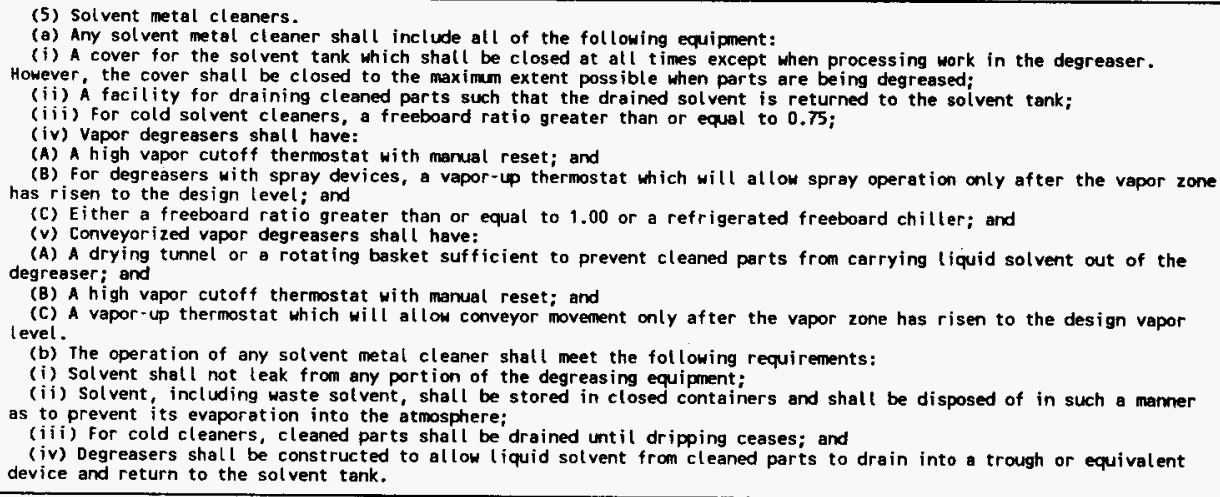 \\
\hline
\end{tabular}


Table 7-1. Constraint Definitions. (100 sheets)

\begin{tabular}{|c|c|}
\hline Constraint Name & Constraint Description \\
\hline $\begin{array}{l}\text { HAC173-460-060 } \\
(5 \mathrm{c} \cdot 6)^{*}\end{array}$ & $\begin{array}{l}\text { (c) For open-top vapor degreasers, solvent drag-out shall be minimized by the following measures; } \\
\text { (i) Racked parts shall be allowed to drain fuly; } \\
\text { (ii) The work load shall be degreased in the vapor zone untit condensation ceases; } \\
\text { (iii) Spraying operations shall be done within the vapor layer: } \\
\text { (iv) When using a powered hoist, the vertical speed of parts in and out of the vapor zone shall be less than three } \\
\text { meters per minute (ten feet per mimute); } \\
\text { (v) When the cover is open, the lip of the degreaser shall not be exposed to steady drafts greater than } 15.3 \text { meters per } \\
\text { minute (f fifty feet per minute); and } \\
\text { (vi) When equipped with a lip exhaust, the fan shall be turned off when the cover is closed. } \\
\text { (d) For conveyorized vapor degreasers, solvent drag-out shall be minimized by the following measures: } \\
\text { (i) Racked parts shall be allowed to drain fully; and } \\
\text { (ii) Vertical conveyor speed shall be maintained at less than three meters per minute (ten feet per minute). } \\
\text { (b) Abrasive blasting. } \\
\text { (a) Abrasive blasting shall be performed inside a booth or hangar designed to capture the blast grit or overspray. } \\
\text { (b) Outdoor blasting of structures or ittems too large to be reasonably handled indoors shall employ control measures } \\
\text { such as curtailment during windy periods and enclosure of the area being blasted with tarps. } \\
\text { (c) Outdoor blasting shall be performed with either steel shot or an abrasive containing less then one percent (by } \\
\text { mass) which would pass through a No. } 200 \text { sieve. } \\
\text { (d) All abrasive blasting with sand shall be performed inside a blasting booth or cabinet. }\end{array}$ \\
\hline UAC173-460-070 & 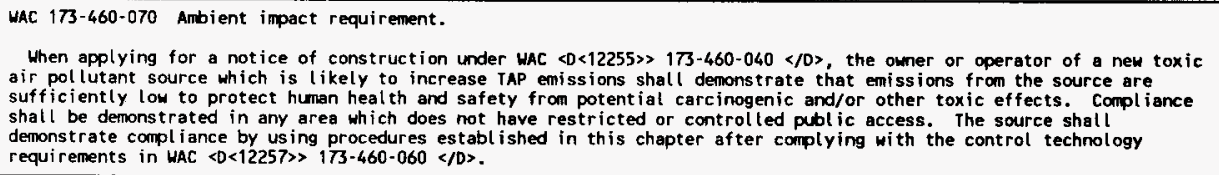 \\
\hline WAC173-460-080 (1)* & $\begin{array}{l}\text { WAC } 173-460-080 \text { Demonstrating ambient impact compl iance. } \\
\text { (1) When applying for a notice of construction under HAC }<0<12255\rangle>173-460-040</ D\rangle \text {, the oumer or operator of a new } \\
\text { toxic a i pollutant source which is likely to increase TAP emissions shall complete an occeptable source impact level } \\
\text { analysis for Class A and Class B TAPs. The authority may complete this analysis. }\end{array}$ \\
\hline
\end{tabular}


Table 7-1. Constraint Definitions. (100 sheets)

\begin{tabular}{|c|c|}
\hline Constraint Name & Constraint Description \\
\hline $\begin{array}{l}\text { wac } 173-460-080 \\
(2 a-2 d)^{*}\end{array}$ & 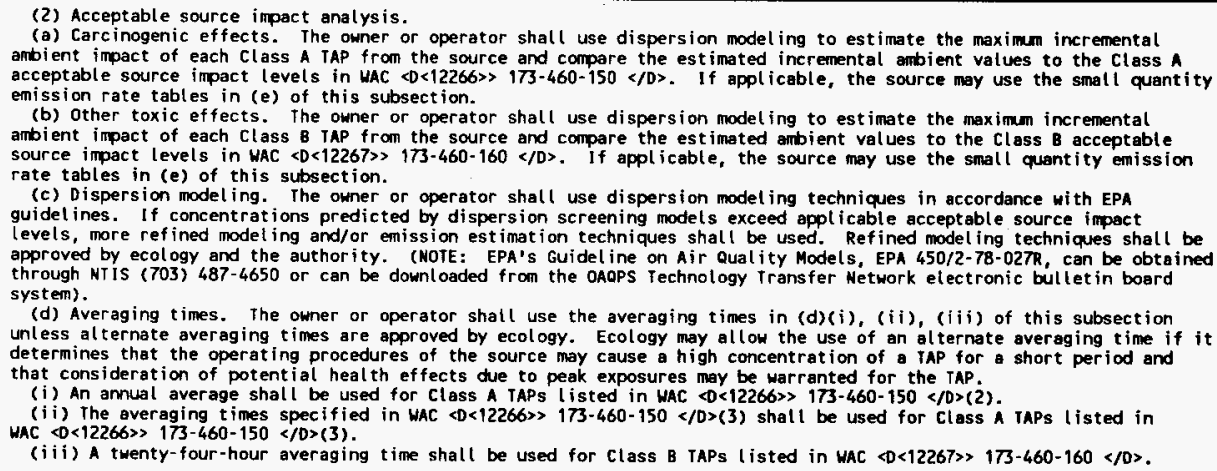 \\
\hline
\end{tabular}


Table 7-1. Constraint Definitions. (100 sheets)

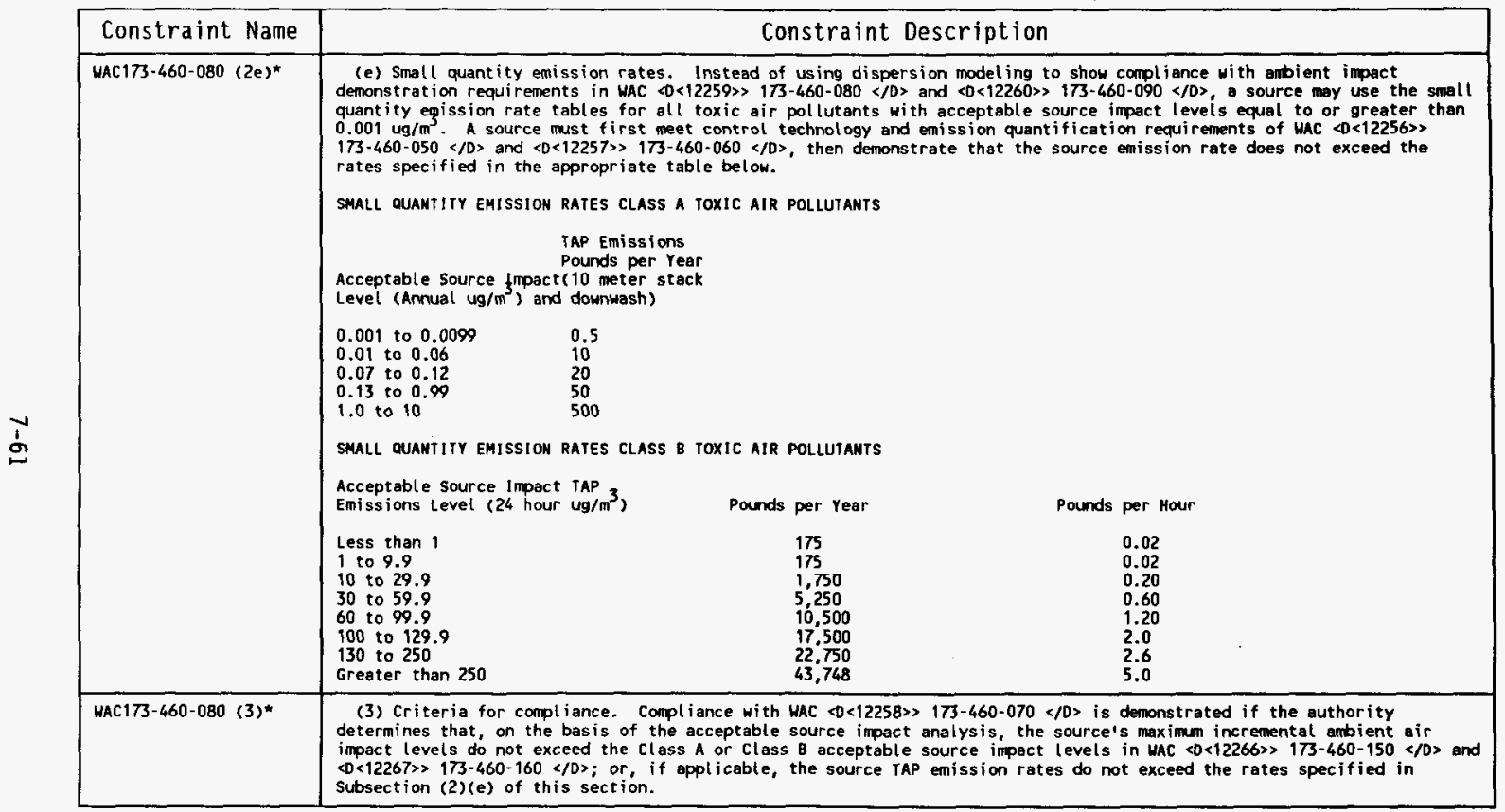


Table 7-1. Constraint Definitions. (100 sheets)

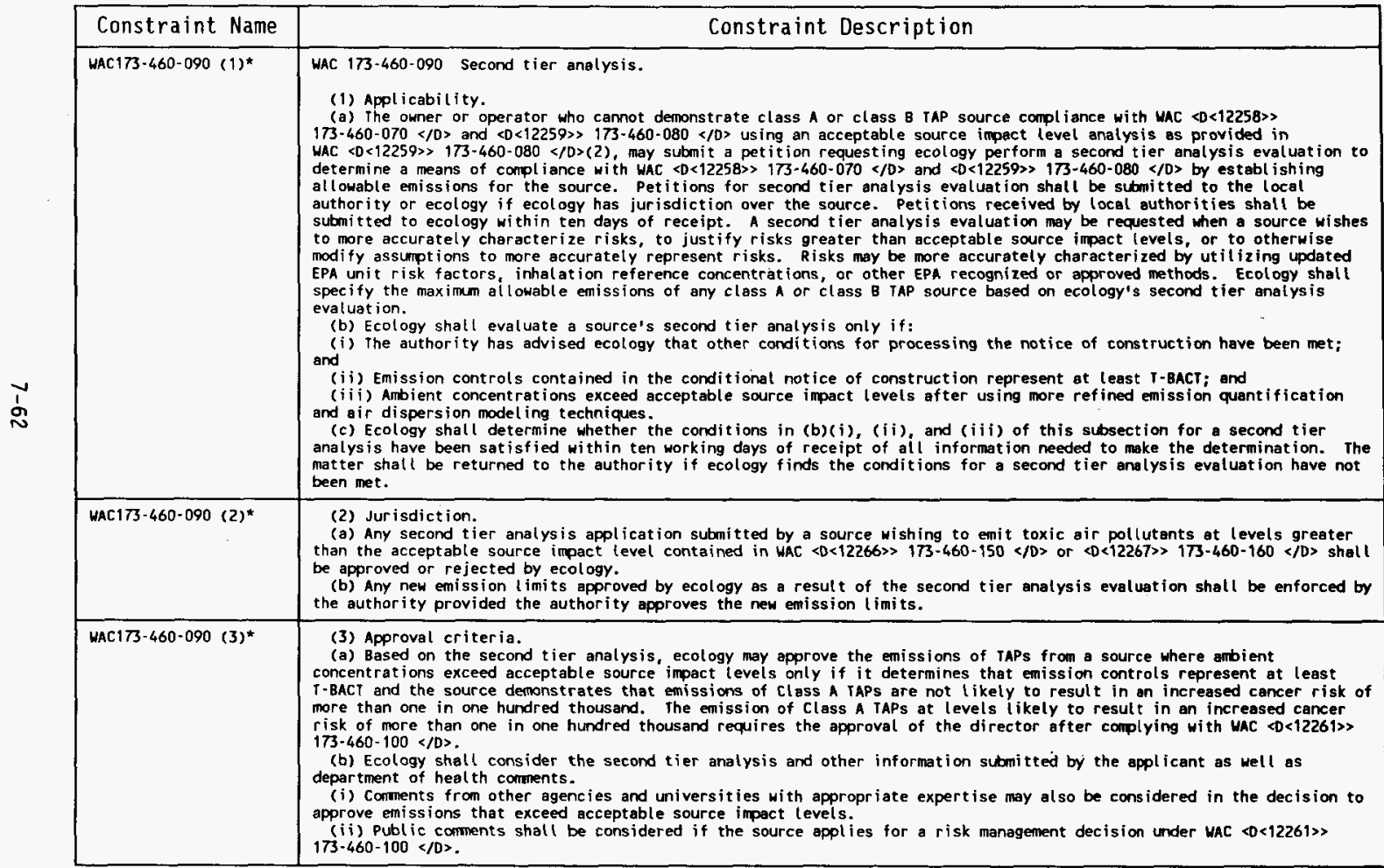


Table 7-1. Constraint Definitions. (100 sheets)

\begin{tabular}{|c|c|}
\hline Constraint Name & Constraint Description \\
\hline HAC173-460-090 (4)* & 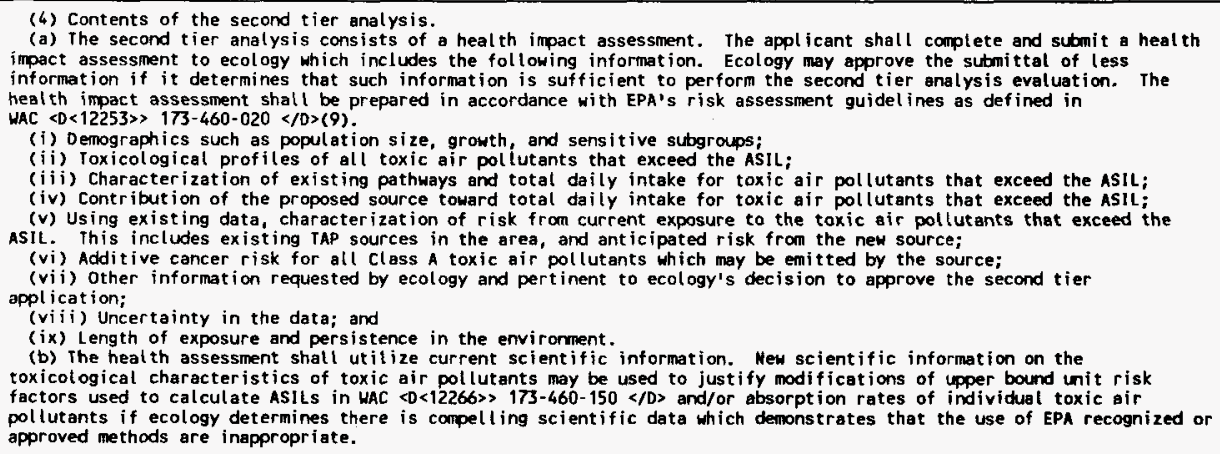 \\
\hline HAC173-460-090 (6)* & 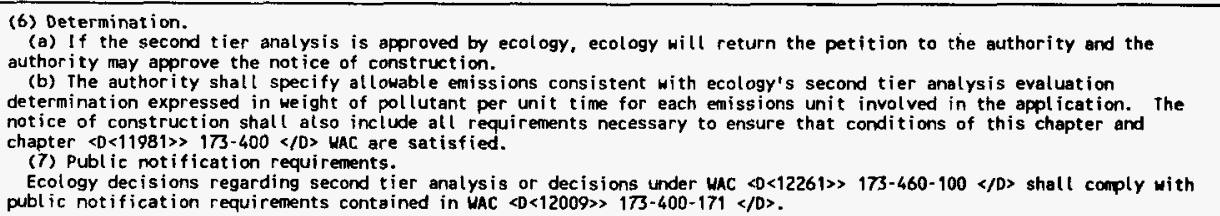 \\
\hline
\end{tabular}


Table 7-1. Constraint Definitions. (100 sheets)

\begin{tabular}{|c|c|}
\hline Constraint Name & Constraint Description \\
\hline NAC $173-460-100$ & 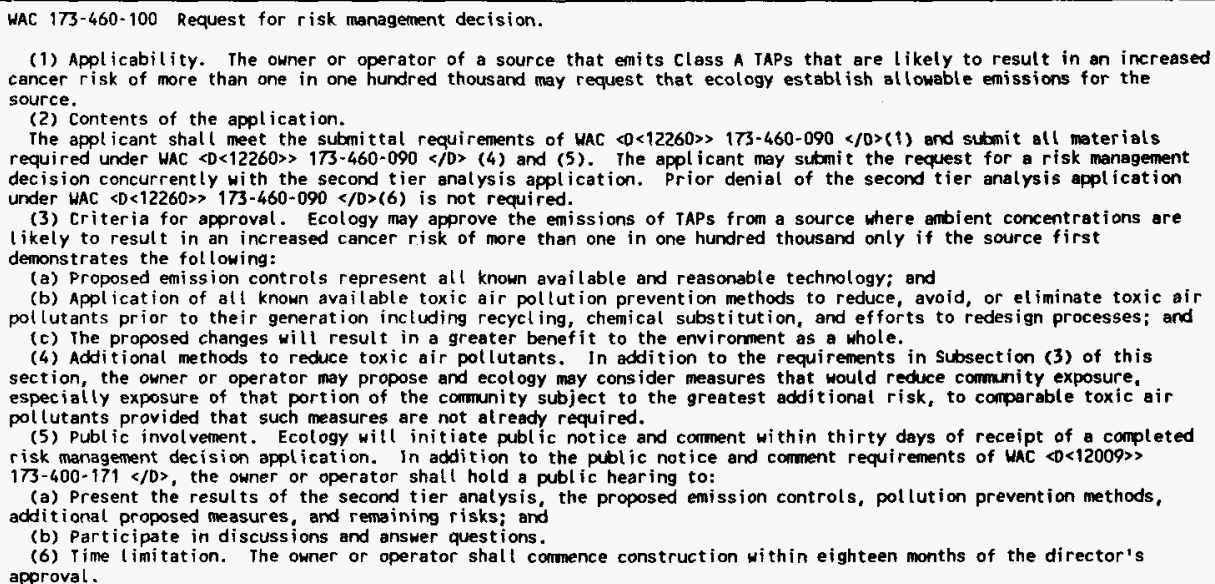 \\
\hline
\end{tabular}


Table 7-1. Constraint Definitions. (100 sheets)

\begin{tabular}{|c|c|}
\hline Constraint Name & Constraint Description \\
\hline WAC $173-460-110$ & 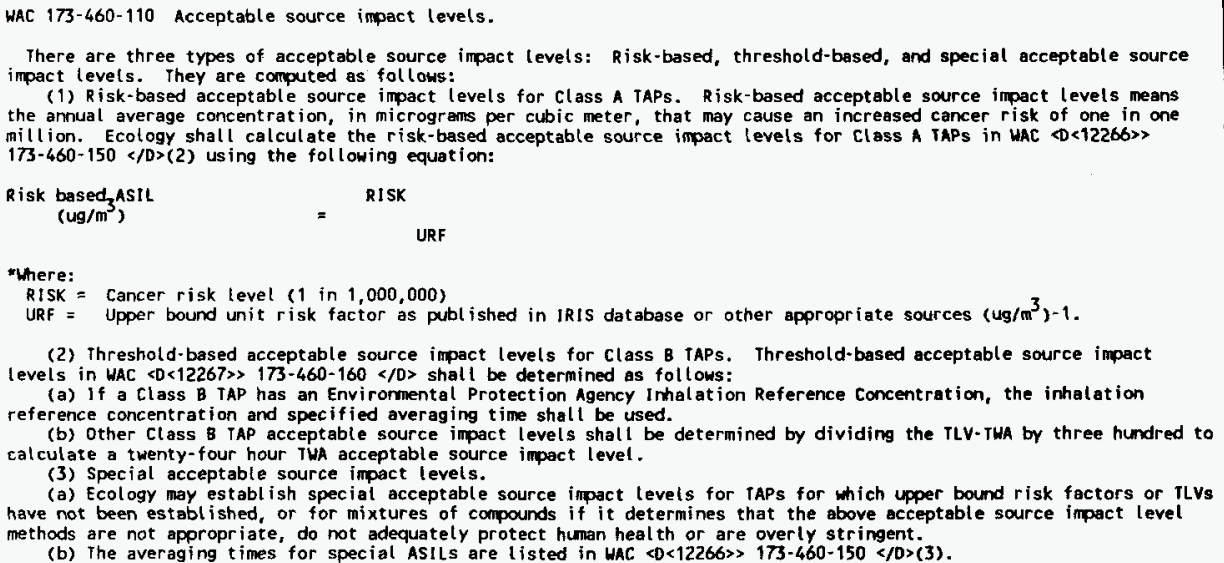 \\
\hline WAC $173-460-120$ & 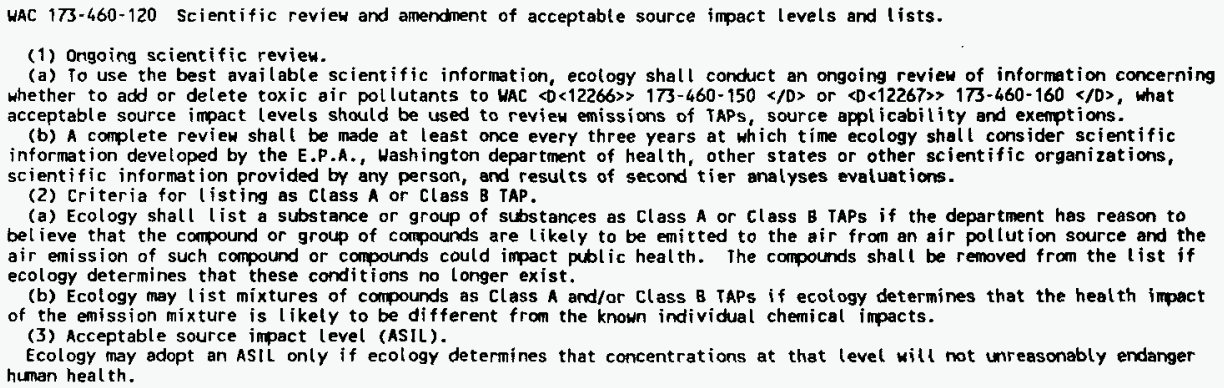 \\
\hline
\end{tabular}


Table 7-1. Constraint Definitions. (100 sheets)

\begin{tabular}{|l|l|}
\hline Constraint Name & Constraint Description \\
\hline UAC173-460-130 & $\begin{array}{l}\text { WAC } 173-460-130 \text { Fees. } \\
\text { (1) Pursuant to RCH } 70.94 .152, \text { ecology or the authority may charge a fee for the review of notices of construction. } \\
\text { (2) The fee imposed under this section may not exceed the cost of revieuing plans, specifications, and other } \\
\text { information and administering such notice. }\end{array}$ \\
\hline WAC173-460-140 & $\begin{array}{l}\text { WAC } 173-460-140 \text { Remedies. } \\
\text { violations of this chapter are subject to the penalty provisions and/or other remedies provided in chapter } 70.94 \text { RCW. }\end{array}$ \\
\hline
\end{tabular}

농 
Table 7-1. Constraint Definitions. (100 sheets)

\begin{tabular}{|c|c|}
\hline Constraint Name & Constraint Description \\
\hline $\begin{array}{l}\text { WaC173-460-150-table } 1 \\
\text { (part } 1)^{*}\end{array}$ & 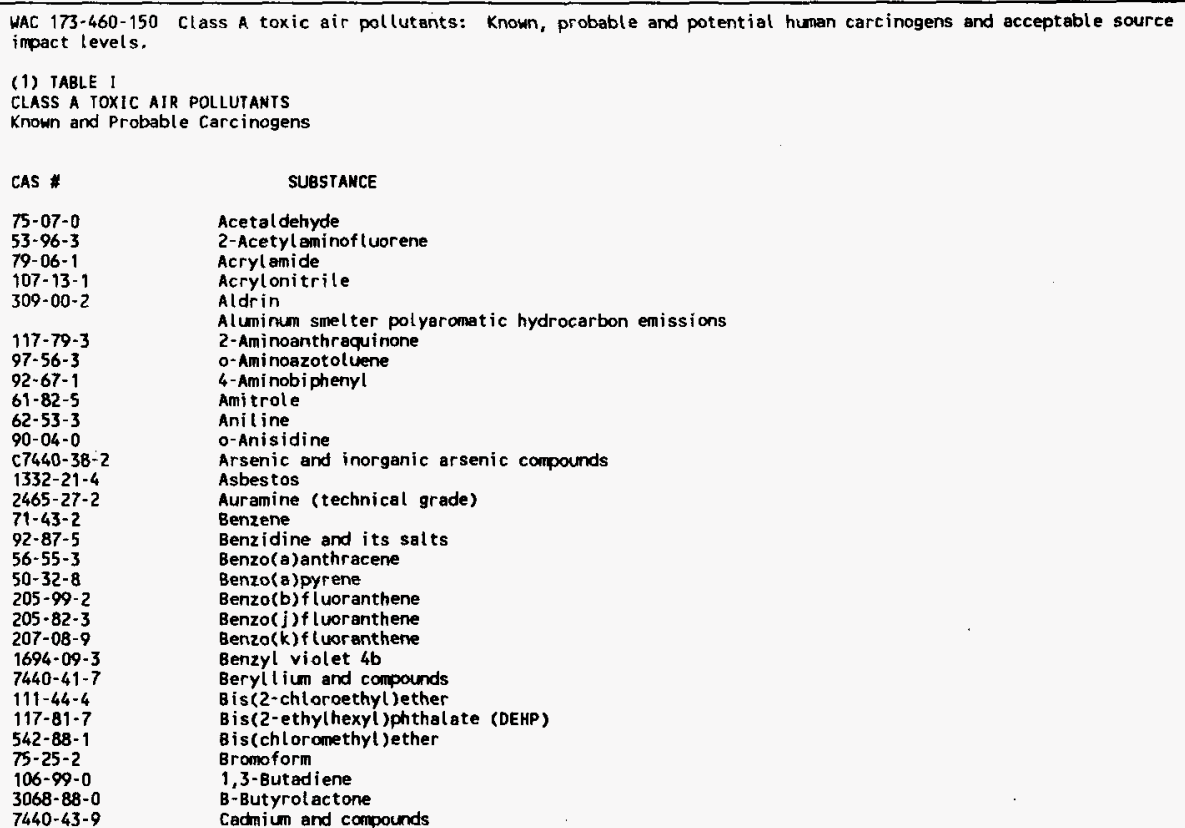 \\
\hline
\end{tabular}


Table 7-1. Constraint Definitions. (100 sheets)

\begin{tabular}{|c|c|c|}
\hline Constraint Name & & Constraint Description \\
\hline $\begin{array}{l}\text { Hac } 173-460-150-\text { Table } 1 \\
(\text { part } 2)^{*}\end{array}$ & $\begin{array}{l}56-23-5 \\
57-74-9 \\
510-15-6 \\
107-30-2 \\
108-43-0 \\
126-99-8 \\
67440-47-3 \\
8001-58-9 \\
135-20-6 \\
94-75-7 \\
3547-04-4 \\
50-29-3 \\
613-35-4 \\
101-80-4 \\
226-36-8 \\
53-70-3 \\
224-42-0 \\
132-64-9 \\
189-64-0 \\
191-30-0 \\
189-55-9 \\
192-65-4 \\
764-41-0 \\
28434-06-8 \\
106-46-7 \\
91-94-1 \\
107-06-2 \\
75-09-2 \\
696-28-6 \\
78-87-5 \\
60-57-1 \\
1615-10-1 \\
101-90-6 \\
119-90-4 \\
119-93-7 \\
77-98-1 \\
540-73-8 \\
123-91-1 \\
122-66-7 \\
106-89-8 \\
106-93-4\end{array}$ & 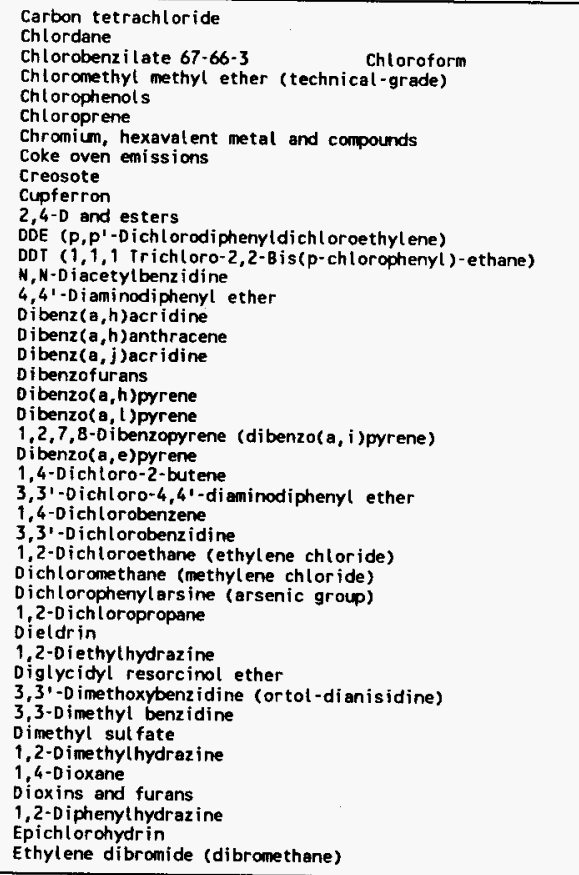 \\
\hline
\end{tabular}


Tab1e 7-1. Constraint Definitions. (100 sheets)

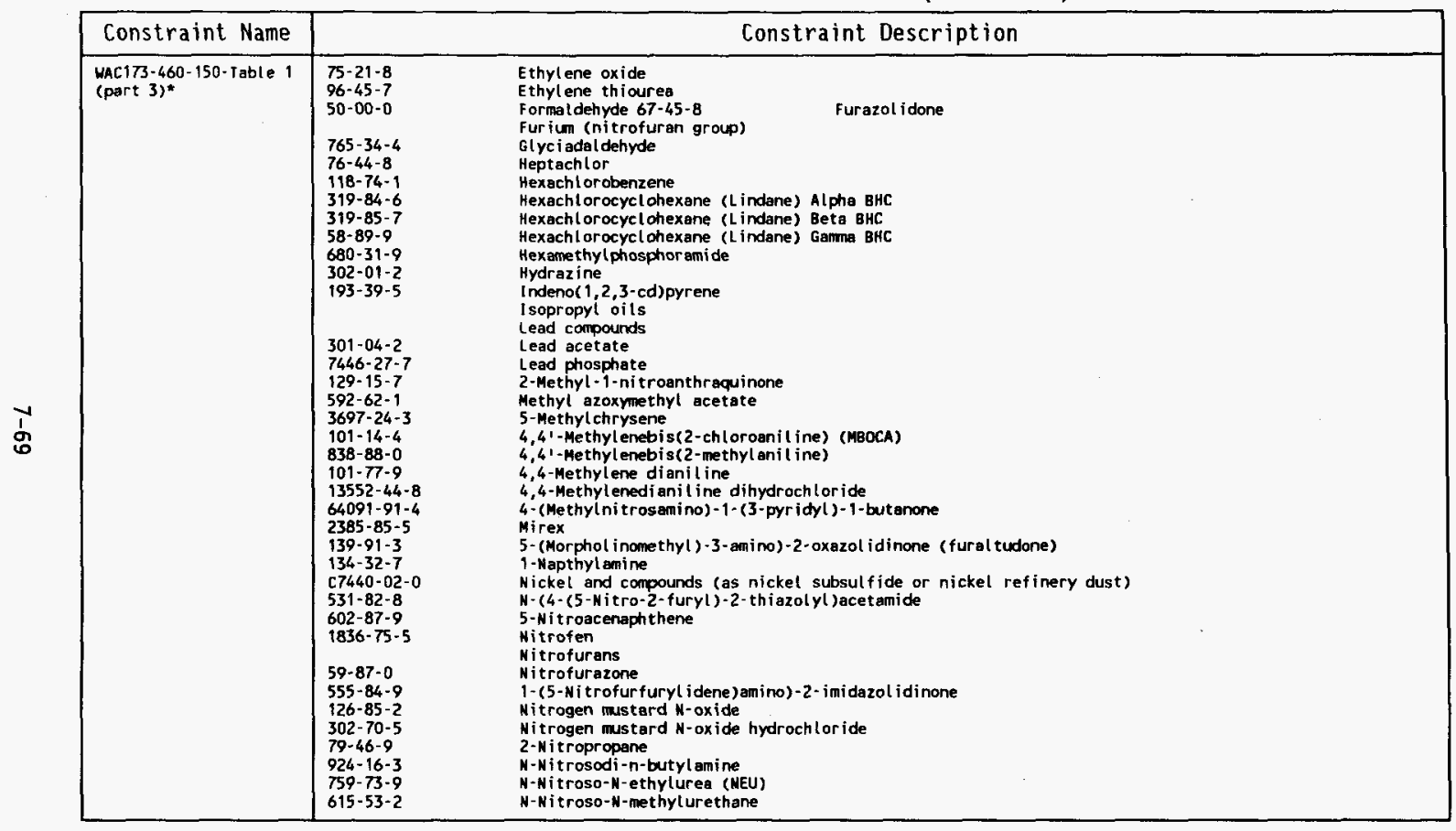


Table 7-1. Constraint Definitions. (100 sheets)

\begin{tabular}{|c|c|c|}
\hline Constraint Name & & Constraint Description \\
\hline $\begin{array}{l}\text { WAC173-460-150-Table } 1 \\
\text { (part } 4)^{*}\end{array}$ & $\begin{array}{l}621-64-1 \\
10595-95-6 \\
59-89-2 \\
86-30-6 \\
55-18-5 \\
62-75-9 \\
2646-17-5 \\
794-93-4 \\
87-86-5 \\
127-18-4 \\
63-92-3 \\
\\
1336-36-3 \\
3761-53-3 \\
1120-71-4 \\
75-56-9 \\
1746-01-6 \\
139-65-1 \\
1314-20-1 \\
95-80-7 \\
584-84-9 \\
95-53-4 \\
636-21-5 \\
8001-35-2 \\
55738-54-0 \\
79-01-6 \\
88-06-2 \\
75-01-4\end{array}$ & 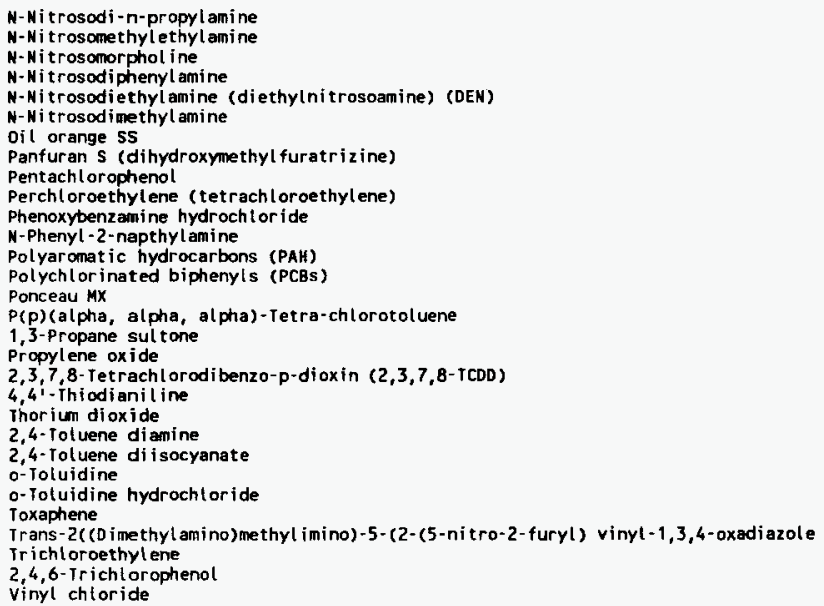 \\
\hline
\end{tabular}


Table 7-1. Constraint Definitions. (100 sheets)

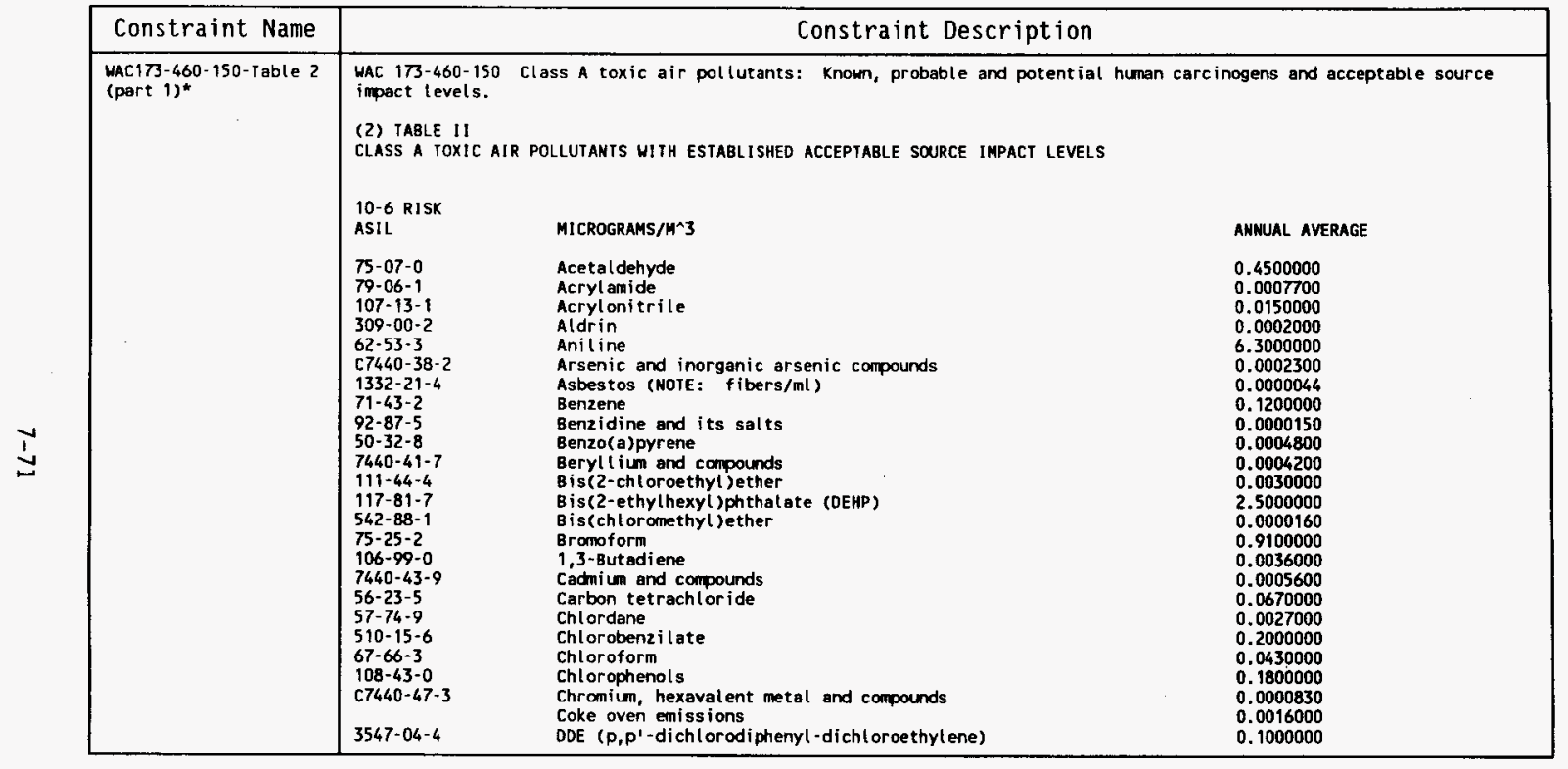


Table 7-1. Constraint Definitions. (100 sheets)

\begin{tabular}{|c|c|c|c|}
\hline Constraint Name & \multicolumn{3}{|c|}{ Constraint Description } \\
\hline $\begin{array}{l}\text { WaC173-460-150-Table } 2 \\
\text { (part } 2)^{*}\end{array}$ & $\begin{array}{l}50-29-3 \\
764-41-0 \\
106-46-7 \\
91-94-1 \\
107-06-2 \\
75-09-2 \\
60-57-1 \\
119-93-7 \\
123-91-1 \\
122-66-7 \\
106-89-8 \\
106-93-4 \\
75-21-8 \\
96-45-7 \\
50-00-0 \\
76-44-8 \\
118-74-1 \\
58-89-9 \\
302-01-2 \\
17440-02-0 \\
924-16-3 \\
55-18-5 \\
62-75-9 \\
79-46-9 \\
87-86-5 \\
127-18-4 \\
1336-36-3 \\
75-56-9 \\
1746-01-6 \\
95-80-7 \\
95-53-4\end{array}$ & 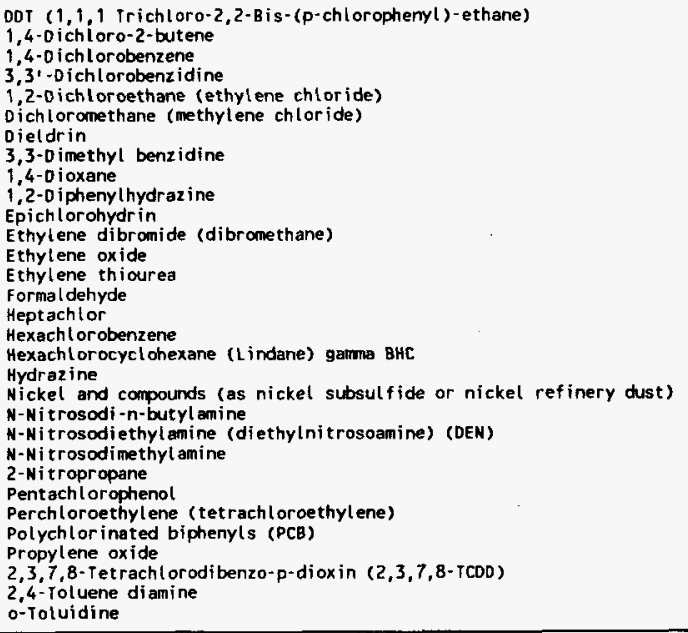 & $\begin{array}{l}0.0100000 \\
0.0003800 \\
1.500000 \\
0.0770000 \\
0.0380000 \\
0.5600000 \\
0.0002200 \\
0.0038000 \\
0.0320000 \\
0.0045000 \\
0.8300000 \\
0.0045000 \\
0.0100000 \\
1.0000000 \\
0.0770000 \\
0.0007700 \\
0.0022000 \\
0.0026000 \\
0.0002000 \\
0.0021000 \\
0.0006300 \\
0.0000230 \\
0.0000710 \\
0.0003700 \\
0.3300000 \\
1.1000000 \\
0.0045000 \\
0.2700000 \\
0.00000003 \\
0.0110000 \\
0.1400000\end{array}$ \\
\hline $\begin{array}{l}\text { Haci73-460-150-Table } 2 \\
\text { (part } 3)^{*}\end{array}$ & $\begin{array}{l}636-21-5 \\
8001-35-2 \\
79-01-6 \\
88-06-2 \\
75-01-4\end{array}$ & $\begin{array}{l}\text { 0-Toluidine hydrochloride } \\
\text { Toxaphene } \\
\text { Trichloroethylene } \\
2,4,6-\text { Trichlorophenol } \\
\text { Vinyl chloride }\end{array}$ & $\begin{array}{l}0.1400000 \\
0.0031000 \\
0.5900000 \\
0.3200000 \\
0.0120000\end{array}$ \\
\hline
\end{tabular}


Table 7-1. Constraint Definitions. (100 sheets)

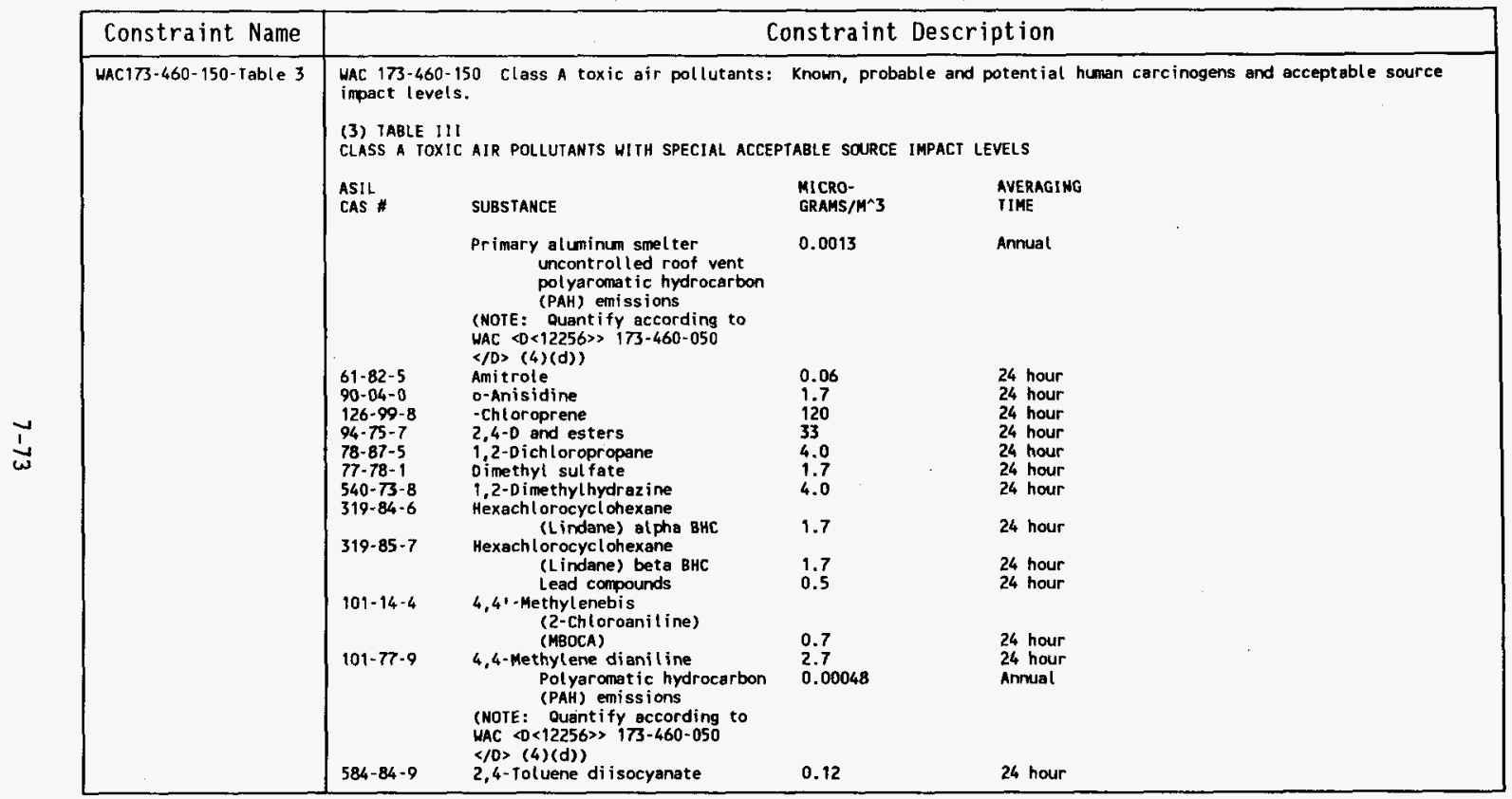


Table 7-1. Constraint Definitions. (100 sheets)

\begin{tabular}{|c|c|c|c|}
\hline Constraint Name & \multicolumn{3}{|c|}{ Constraint Description } \\
\hline MAC $173-460-160(01)^{*}$ & $\begin{array}{l}\text { HAC } 173-46 \\
\text { The follo } \\
\\
\text { ASIL } \\
\text { CAS\# } \\
86-88-4 \\
60-35-5 \\
64-19-7 \\
108-24-7 \\
67-64-1 \\
75-05-8 \\
98-86-2 \\
79-27-6 \\
107-02-8 \\
79-10-7 \\
107-18-6 \\
107-05-1 \\
106-92-3 \\
2179-59-1 \\
\text { C7429-90-5 } \\
7429-90-5 \\
\text { C7429-90-5 } \\
\text { C7429-90-5 } \\
\text { C7429-90-5 } \\
504-29-0 \\
7664-41-7 \\
12125-02-9 \\
3825-26-1 \\
7773-06-0 \\
628-63-7 \\
626-38-0 \\
62-53-3 \\
29191-52-4 \\
\text { c7440-36-0 } \\
1309-64-4\end{array}$ & 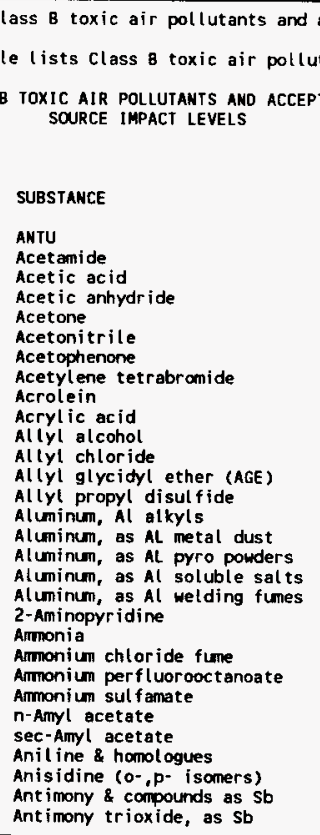 & $\begin{array}{l}\text { impact levels. } \\
\text { ble source impact levels: } \\
\\
\text { MICROGRAMS/MA3 } \\
\text { TWENTY-FOUR-HOUR } \\
\text { AVERAGE } \\
1.0 \\
83 \\
67 \\
5900 \\
220 \\
47 \\
0.02 \\
0.30 \\
17 \\
1.0 \\
77 \\
40.0 \\
6.7 \\
33 \\
17 \\
6.7 \\
17 \\
6.3 \\
100 \\
33 \\
0.33 \\
33 \\
1800 \\
2200 \\
1.0 \\
1.7 \\
1.7 \\
1.7\end{array}$ \\
\hline
\end{tabular}


Table 7-1. Constraint Definitions. (100 sheets)

\begin{tabular}{|c|c|c|c|}
\hline Constraint Name & \multicolumn{3}{|c|}{ Constraint Description } \\
\hline WAC173-460-160(02)* & $\begin{array}{l}7784-42-1 \\
8052-42-4 \\
1912-24-9 \\
86-50-0 \\
67440-39-3 \\
17804-35-2 \\
98-07-7 \\
94-36-0 \\
100-44-7 \\
92-52-4 \\
1304-82-1 \\
1304-82-1 \\
11303-96-4 \\
11303-96-4 \\
11303-96-4 \\
1303-86-2 \\
10294-33-4 \\
76737-07-2 \\
314-40-9 \\
7726-95-6 \\
7789-30-2 \\
106-97-8 \\
111-76-2 \\
123-86-4 \\
105-46-4 \\
540-88-5 \\
141-32-2 \\
71-36-3 \\
78-92-2 \\
75-65-0 \\
1189-85-1 \\
2426-08-6 \\
138-22-7 \\
109-79-5 \\
109-73-9 \\
89-72-5 \\
98-51-1 \\
156-62-7 \\
1305-62-0 \\
1305-78-8 \\
76-22-2 \\
105-60-2 \\
105-60-2\end{array}$ & 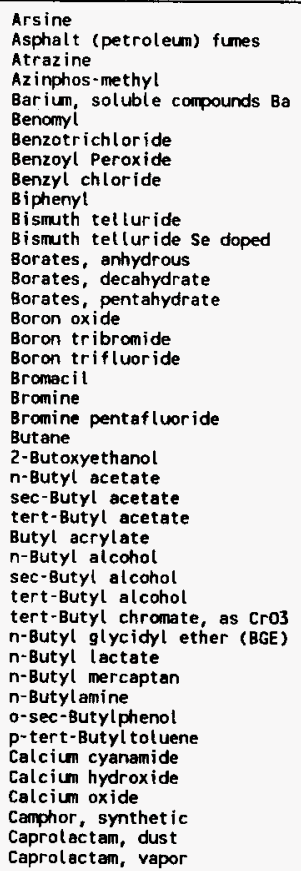 & $\begin{array}{l}0.53 \\
17 \\
17 \\
0.67 \\
1.7 \\
33 \\
17 \\
17 \\
4.3 \\
33 \\
17 \\
3.3 \\
17 \\
3.3 \\
33 \\
33 \\
9.3 \\
33 \\
2.2 \\
2.4 \\
6300.0 \\
400 \\
2400 \\
3200 \\
3200 \\
170 \\
500 \\
1000 \\
1000 \\
0.33 \\
440 \\
83 \\
6.0 \\
50.0 \\
100 \\
200 \\
1.7 \\
17 \\
6.7 \\
40 \\
3.3 \\
67\end{array}$ \\
\hline
\end{tabular}


Table 7-1. Constraint Definitions. (100 sheets)

\begin{tabular}{|c|c|c|c|}
\hline Constraint Name & \multicolumn{3}{|c|}{ Constraint Description } \\
\hline MAC173. $460-160(03)^{*}$ & $\begin{array}{l}2425-06-1 \\
133-06-2 \\
63-25-2 \\
1563-66-2 \\
1333-86-4 \\
75-15-0 \\
558-13-4 \\
353-50-4 \\
463-58-1 \\
120-80-9 \\
21351-99-1 \\
133-90-4 \\
55720-99-5 \\
7782-50-5 \\
10049-04-4 \\
7790-91-2 \\
600-25-9 \\
107-20-0 \\
79-11-8 \\
532-27-4 \\
79-04-9 \\
2698-41-1 \\
108-90-7 \\
74-97-5 \\
75-45-6 \\
76-15-3 \\
76-06-2 \\
2039-87-4 \\
95-49-8 \\
2921-88-2 \\
C 7440-47-3 \\
C 7440-47-3 \\
7440-47-3 \\
14977-61-8 \\
2971-90-6 \\
7440-48-4 \\
10210-68-1 \\
16862-03-8 \\
67440-50-8 \\
7440-50-8 \\
1319-77-3\end{array}$ & 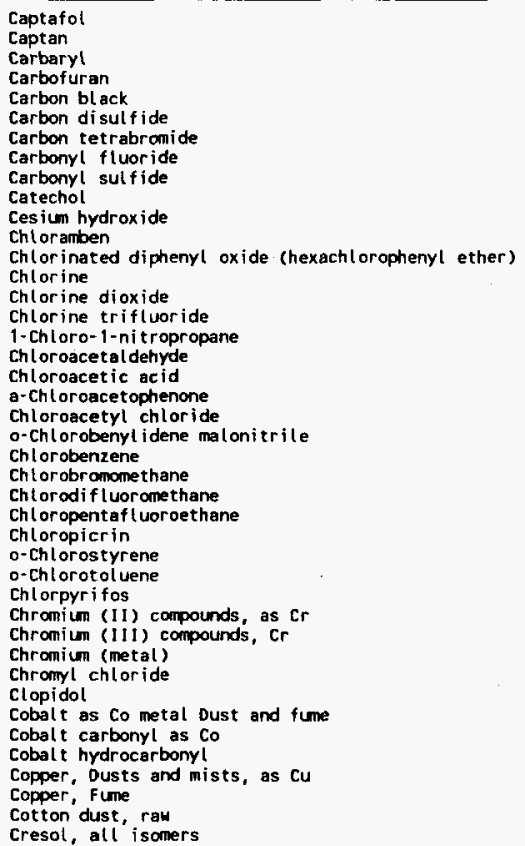 & $\begin{array}{l}0.33 \\
17 \\
17 \\
0.33 \\
12 \\
100 \\
4.7 \\
18 \\
77 \\
6.7 \\
1.7 \\
5.0 \\
0.2 \\
1.3 \\
33 \\
11 \\
1.1 \\
0.67 \\
1.3 \\
150 \\
3500 \\
12000 \\
21000 \\
2.2 \\
940 \\
860 \\
0.67 \\
1.7 \\
1.7 \\
1.7 \\
0.53 \\
33 \\
0.17 \\
0.33 \\
0.33 \\
3.3 \\
0.67 \\
0.67 \\
73\end{array}$ \\
\hline
\end{tabular}


Table 7-1. Constraint Definitions. (100 sheets)

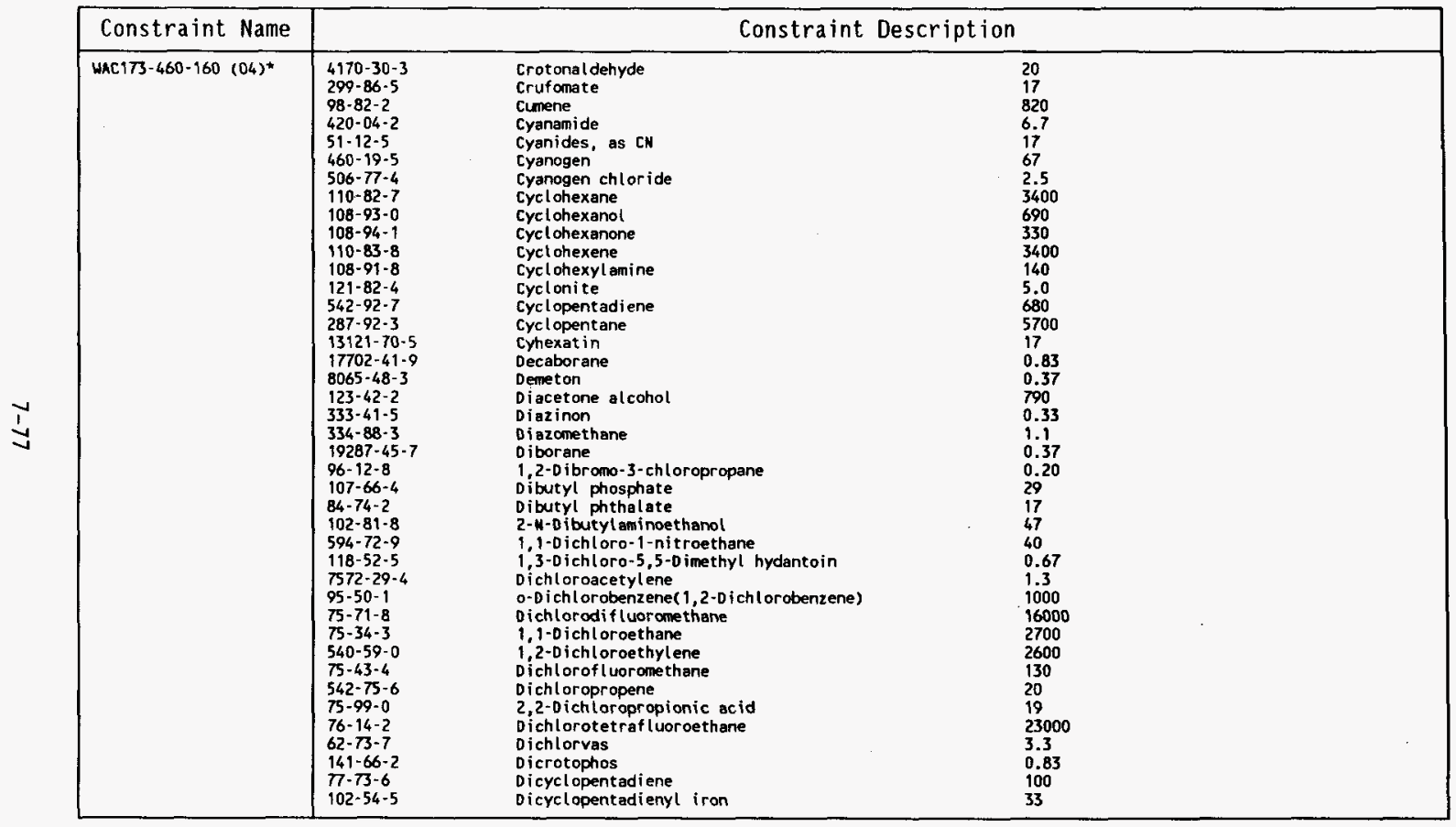


Table 7-1. Constraint Definitions. (100 sheets)

\begin{tabular}{|c|c|c|c|}
\hline Constraint Name & \multicolumn{3}{|c|}{ Constraint Description } \\
\hline NAC173-460-160 (05)* & $\begin{array}{l}111-42-2 \\
96-22-0 \\
84-66-2 \\
64-67-5 \\
109-89-7 \\
100-37-8 \\
111-40-0 \\
75-61-6 \\
2238-07-5 \\
108-83-8 \\
108-18-9 \\
127-19-5 \\
60-11-7 \\
79-44-7 \\
124-40-3 \\
121-69-7 \\
68-12-2 \\
57-14-7 \\
131-11-3 \\
148-01-6 \\
534-52-1 \\
528-29-0 \\
51-28-5 \\
121-14-2 \\
78-34-2 \\
122-39-4 \\
123-19-3 \\
34590-94-8 \\
85-00-7 \\
97-77-8 \\
298-04-4 \\
128-37-0 \\
330-54-1 \\
1321-74-0 \\
2104-64-5 \\
115-29-7 \\
72-20-8 \\
13838-16-9 \\
106-88-7 \\
141-43-5 \\
563-12-2 \\
110-80-5\end{array}$ & 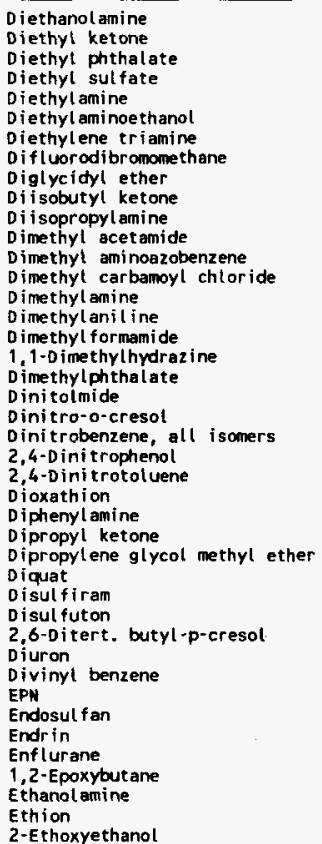 & $\begin{array}{l}43 \\
2300 \\
17 \\
100 \\
170 \\
14 \\
2900 \\
1.7 \\
480 \\
67 \\
120 \\
\\
60 \\
83 \\
30 \\
4.0 \\
17 \\
17 \\
0.67 \\
3.3 \\
5.0 \\
0.67 \\
33 \\
780 \\
2000 \\
1.7 \\
6.7 \\
0.33 \\
33 \\
33 \\
180 \\
1.7 \\
0.33 \\
0.33 \\
1900 \\
20 \\
25 \\
1.3 \\
200\end{array}$ \\
\hline
\end{tabular}


Table 7-1. Constraint Definitions. (100 sheets)

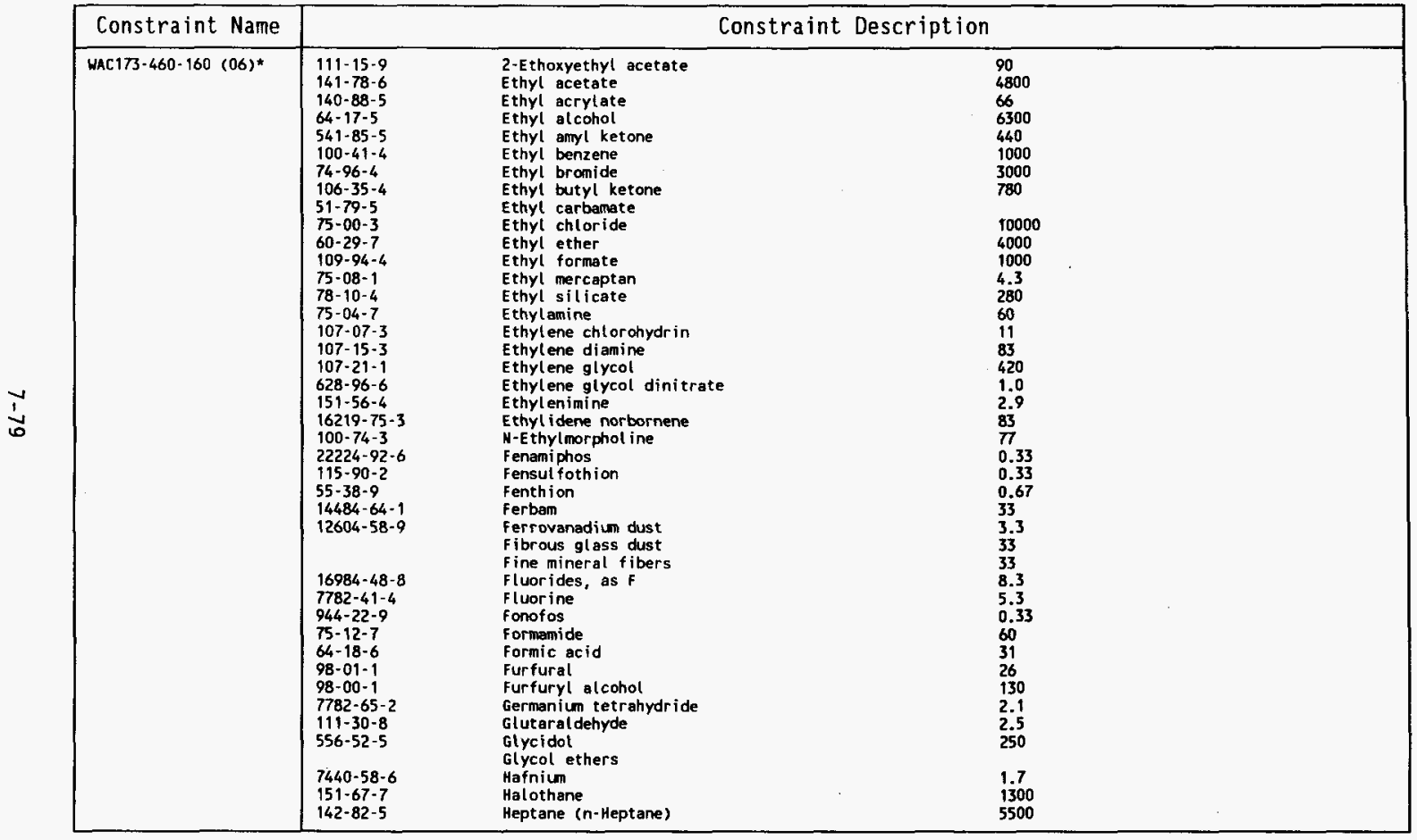


Table 7-1. Constraint Definitions. (100 sheets)

\begin{tabular}{|c|c|c|c|}
\hline Constraint Name & \multicolumn{3}{|c|}{ Constraint Description } \\
\hline HAC173-460-160 (07)* & $\begin{array}{l}87-68-3 \\
77-47-4 \\
67-72-1 \\
135-87-1 \\
684-16-2 \\
822-06-0 \\
100-54-3 \\
591-78-6 \\
108-84-9 \\
107-41-5 \\
10035-10-6 \\
7647-01-0 \\
74-90-8 \\
764-39-3 \\
7722-84-1 \\
7783-07-5 \\
773-06-4 \\
123-31-9 \\
999-61-1 \\
95-13-6 \\
67440-74-6 \\
753-56-2 \\
75-47-8 \\
1309-37-1 \\
13463-40-6 \\
123-92-2 \\
133-51-3 \\
110-19-0 \\
78-83-1 \\
26952-21-6 \\
78-59-1-6 \\
4098-71-9 \\
109-59-9 \\
108-21-4 \\
67-63-0 \\
108-20-3 \\
4016-14-2 \\
75-31-0 \\
768-52-5 \\
463-51-4 \\
3687-31-8\end{array}$ & 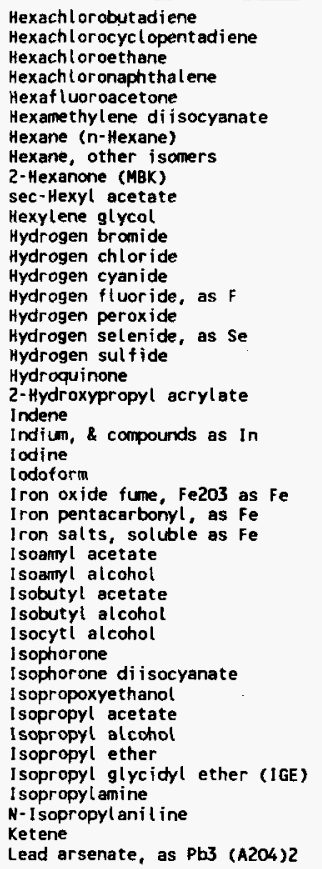 & $\begin{array}{l}0.70 \\
0.33 \\
32 \\
0.67 \\
2.3 \\
0.11 \\
200 \\
5900 \\
67 \\
980 \\
400 \\
33 \\
7.0 \\
37 \\
8.7 \\
4.7 \\
0.53 \\
0.9 \\
6.7 \\
9.3 \\
160 \\
0.33 \\
3.3 \\
33 \\
17 \\
0.83 \\
3.3 \\
1700 \\
1200 \\
2400 \\
510 \\
890 \\
93 \\
0.15 \\
350 \\
3500 \\
3300 \\
3500 \\
790 \\
40 \\
37 \\
2.9 \\
0.50\end{array}$ \\
\hline
\end{tabular}


Table 7-1. Constraint Definitions. (100 sheets)

\begin{tabular}{|c|c|c|c|}
\hline Constraint Name & \multicolumn{3}{|c|}{ Constraint Description } \\
\hline HAC $173-460-160(08)^{*}$ & $\begin{array}{l}7758-97-6 \\
68476-85-7 \\
7580-67-8 \\
1309-48-4 \\
121-75-5 \\
108-31-6 \\
17439-6-5-5 \\
c 7439-96-5 \\
12079-65-1 \\
17439-97-6 \\
c 7439-97-6 \\
67439-97-6 \\
141-79-7 \\
79-41-4 \\
16752-77-5 \\
72-43-5 \\
109-86-4 \\
110-49-6 \\
150-76-5 \\
137-05-3 \\
79-20-9 \\
74-99-7 \\
59355-75-8 \\
96-33-3 \\
67-56-1 \\
100-61-8 \\
74-83-9 \\
74-87-3 \\
71-55-6 \\
8022-00-2 \\
78-93-3 \\
1338-23-4 \\
107-31-3 \\
60-34-4 \\
74-88-4 \\
110-12-3 \\
108-11-2 \\
108-10-1 \\
624-83-9 \\
563-80-4\end{array}$ & $\begin{array}{l}\text { Lead chromate, as } \mathrm{Cr} \\
\text { Liquified petroleum gas } \\
\text { Lithium hydride } \\
\text { Magnes ium oxide fume } \\
\text { Malathion } \\
\text { Maleic anhydride } \\
\text { Manganese dust \& compounds } \\
\text { Manganese fume } \\
\text { Manganese crelopentadienyl tricarbonyl } \\
\text { Mercury, Aryl \& inorganic cmpd } \\
\text { Mercury, as Hg Alkyl compounds } \\
\text { Mercury, vapors except alkyl } \\
\text { Mesityl oxide } \\
\text { Methacryl ic acid } \\
\text { Methomyl } \\
\text { Methoxychlor } \\
\text { 2-Methoxyethanol } \\
\text { 2-Methoxyethyl acetate } \\
\text { 4-Methoxphenol } \\
\text { Methyl } 2 \text {-cyanoacrylate } \\
\text { Methyl acetate } \\
\text { Methyl acetylene } \\
\text { Methyl acetylene-propadiene mixture (MAPP) } \\
\text { Methyl acrylate } \\
\text { Methyl alcohol } \\
\text { N-Methyl aniline } \\
\text { Methyl bromide } \\
\text { Methyl chloride } \\
\text { Methyl chloroform (1,1,1-Irichloroethane) } \\
\text { Methyl demetor } \\
\text { Methyl ethyl ketone (MEK) } \\
\text { Methyl ethyl ketone peroxide } \\
\text { Methyl formate } \\
\text { Methyl hydrazine } \\
\text { Methyl iodide } \\
\text { Methyl isoanyl ketone } \\
\text { Methyl isobutyl carbinol } \\
\text { Methyl isobutyl ketone (MIBK) } \\
\text { Methyl isocyanate } \\
\text { Methyl isopropyl ketone }\end{array}$ & $\begin{array}{l}0.040 \\
6000 \\
0.080 \\
33 \\
33 \\
3.3 \\
0.40 \\
3.3 \\
0.33 \\
0.33 \\
0.33 \\
0.17 \\
200 \\
230 \\
8.3 \\
33 \\
20 \\
80 \\
17 \\
30 \\
2000 \\
5500 \\
5500 \\
120 \\
870 \\
7.3 \\
5.0 \\
340 \\
6400 \\
1.7 \\
1000 \\
5.0 \\
820 \\
1.2 \\
40 \\
780 \\
350 \\
680 \\
0.16 \\
2300\end{array}$ \\
\hline
\end{tabular}


Table 7-1. Constraint Definitions. (100 sheets)

\begin{tabular}{|c|c|c|c|}
\hline Constraint Name & \multicolumn{3}{|c|}{ Constraint Description } \\
\hline WAC $173-460-160(09)^{\star}$ & $\begin{array}{l}74-93-1 \\
80-62-6 \\
10-43-0 \\
591-78-6 \\
298-00-0 \\
107-87-9 \\
681-84-5 \\
1634-04-4 \\
98-83-9 \\
126-98-7 \\
109-87-5 \\
74-89-5 \\
108-87-2 \\
25639-42-3 \\
583-60-8 \\
12108-13-3 \\
5124-30-1 \\
101-68-8 \\
21087-84-9 \\
7786-34-7 \\
67439-98-7 \\
67439-98-7 \\
6923-22-4 \\
110-91-4 \\
300-76-5 \\
91-20-3 \\
54-11-5 \\
1929-82-4 \\
7697-37-2 \\
10102-43-9 \\
100-01-6 \\
98-95-3 \\
100-00-5 \\
79-24-3 \\
7783-54-2 \\
92-93-3 \\
55-63-0 \\
75-52-5 \\
100-02-7 \\
108-03-2 \\
684-93-5\end{array}$ & 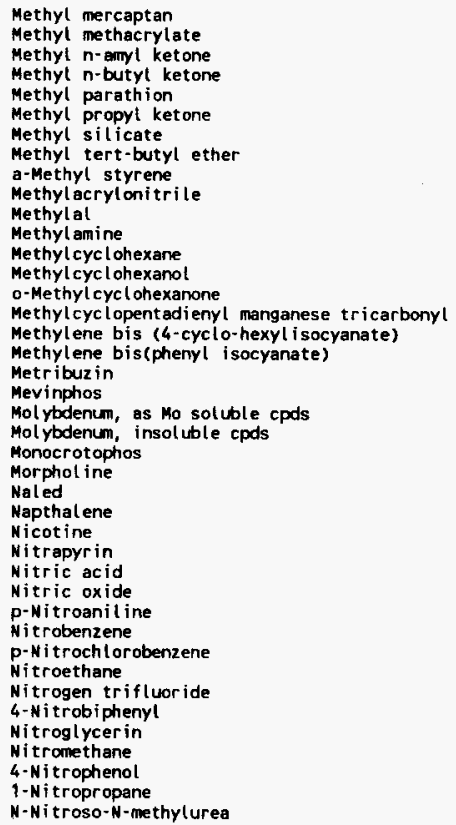 & $\begin{array}{l}3.3 \\
1400 \\
780 \\
67 \\
0.67 \\
2300 \\
20 \\
500 \\
810 \\
9.0 \\
10000 \\
43 \\
5400 \\
780 \\
760 \\
0.67 \\
0.18 \\
0.2 \\
17 \\
0.33 \\
17 \\
33 \\
0.83 \\
240 \\
10 \\
170 \\
1.7 \\
33 \\
17 \\
100 \\
10 \\
1.7 \\
2.0 \\
1000 \\
97 \\
1.5 \\
830 \\
20 \\
20\end{array}$ \\
\hline
\end{tabular}


Table 7-1. Constraint Definitions. (100 sheets)

\begin{tabular}{|c|c|c|c|}
\hline Constraint Name & \multicolumn{3}{|c|}{ Constraint Description } \\
\hline HAC173-460-160(10)* & $\begin{array}{l}88-72-2 \\
111-84-2 \\
2234-13-1 \\
111-65-9 \\
8012-95-1 \\
20816-12-0 \\
144-62-7 \\
7783-41-7 \\
8002-74-2 \\
4685-14-7 \\
56-38-7 \\
19624-22-7 \\
1321-64-8 \\
82-68-8 \\
109-66-0 \\
594-42-3 \\
7616-94-6 \\
108-95-2 \\
92-84-2 \\
101-84-8 \\
122-60-1 \\
108-98-5 \\
106-50-3 \\
100-63-0 \\
638-21-1 \\
298-02-2 \\
75-44-5 \\
7803-511-2 \\
7664-38-2 \\
7723-14-0 \\
10025-87-3 \\
10026-13-8 \\
1314-80-3 \\
7719-12-2 \\
85-44-9 \\
626-17-5 \\
1918-02-1 \\
88-89-1 \\
83-26-1 \\
142-64-3 \\
7440-06-4 \\
07440-06-4\end{array}$ & 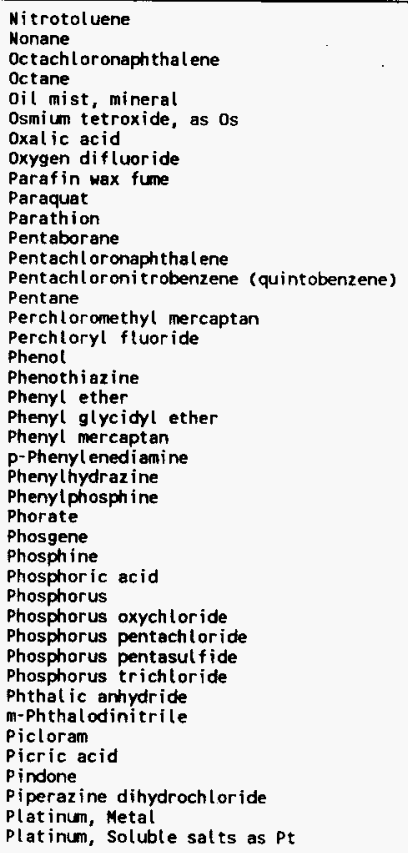 & $\begin{array}{l}37 \\
3500 \\
0.33 \\
4700 \\
17 \\
0.0053 \\
3.3 \\
0.37 \\
6.7 \\
4.5 \\
0.33 \\
0.043 \\
1.7 \\
1.7 \\
6000 \\
2.5 \\
43 \\
63 \\
1.7 \\
23 \\
2000 \\
7.7 \\
0.33 \\
1.5 \\
0.77 \\
0.17 \\
1.3 \\
1.3 \\
3.3 \\
0.33 \\
2.1 \\
2.8 \\
3.3 \\
3.7 \\
20 \\
17 \\
33 \\
0.33 \\
0.033 \\
17 \\
3.3 \\
0.0067\end{array}$ \\
\hline
\end{tabular}


Table 7-1. Constraint Definitions. (100 sheets)

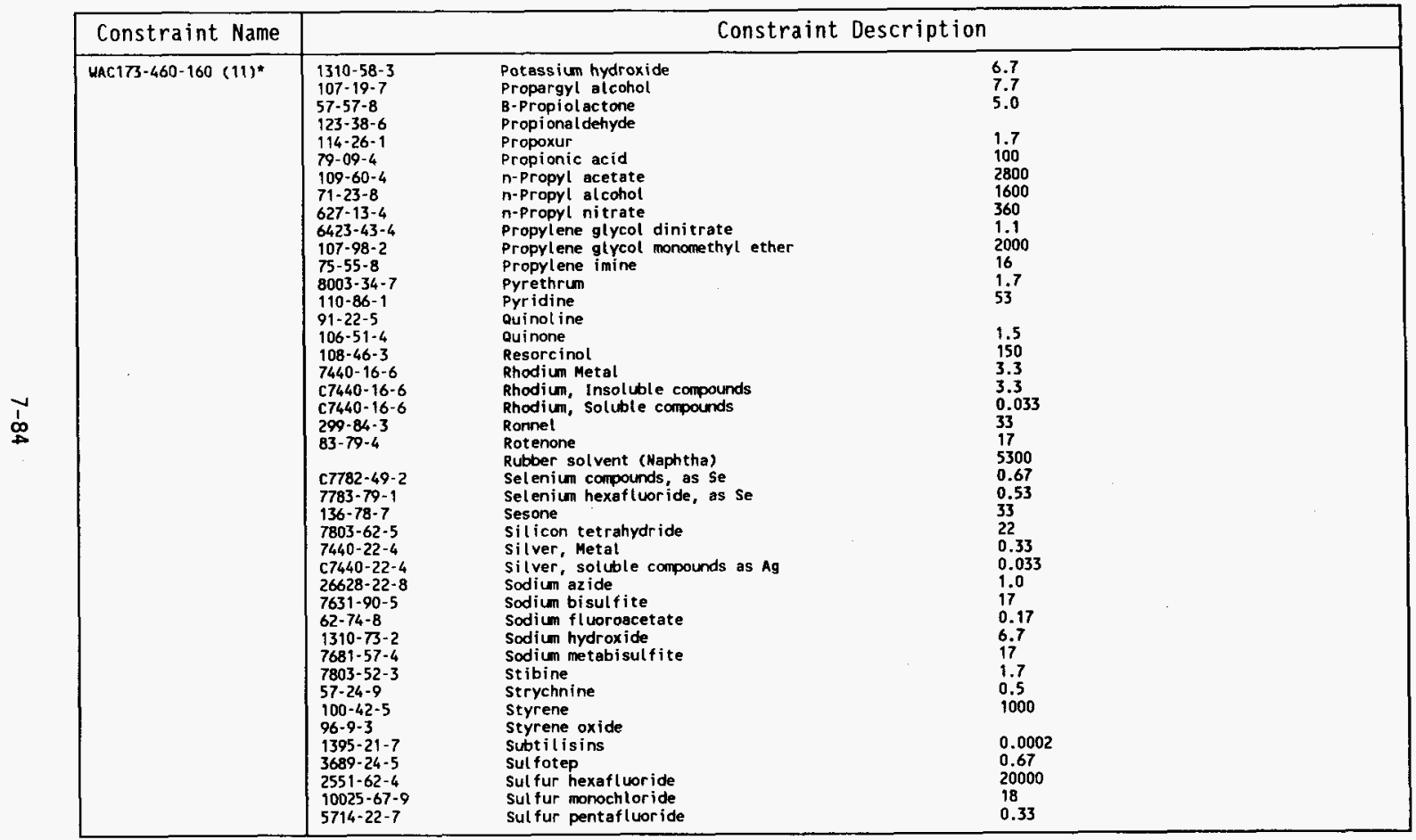


Table 7-1. Constraint Definitions. (100 sheets)

\begin{tabular}{|c|c|c|c|}
\hline Constraint Name & \multicolumn{3}{|c|}{ Constraint Description } \\
\hline WAC173-460-160(12)* & $\begin{array}{l}7783-60-0 \\
7664-93-9 \\
2699-79-8 \\
35400-43-2 \\
93-76-5 \\
107-49-3 \\
6740-25-7 \\
613494-80-9 \\
7783-80-4 \\
3383-96-8 \\
26140-60-3 \\
76-12-0 \\
76-11-9 \\
79-34-5 \\
1335-88-2 \\
78-00-2 \\
109-99-9 \\
75-94-1 \\
333-52-6 \\
509-14-8 \\
772-88-5 \\
479-45-8 \\
67440-28-0 \\
96-69-5 \\
68-11-1 \\
7719-09-7 \\
137-26-8 \\
7440-31-5 \\
c 7440-31-5 \\
740-31-5 \\
7550-45-0 \\
108-88-3 \\
108-44-1 \\
106-49-0 \\
126-73-8 \\
76-13-1 \\
76-03-9 \\
120-82-1\end{array}$ & 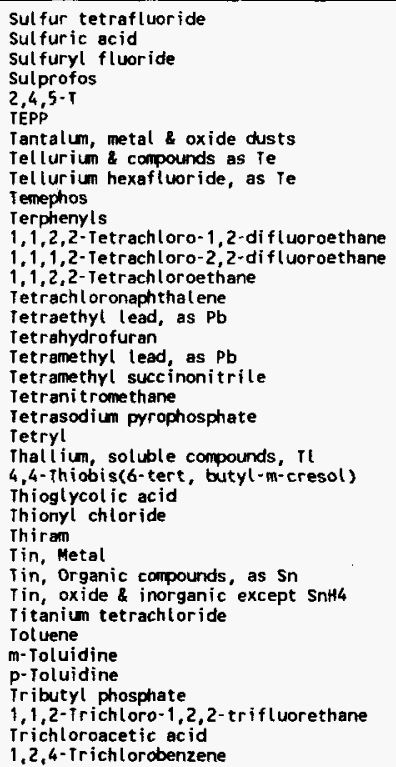 & $\begin{array}{l}1.5 \\
3.3 \\
67.3 \\
3.3 \\
33 \\
0.16 \\
17 \\
0.33 \\
0.33 \\
33 \\
16 \\
14000 \\
14000 \\
23 \\
6.7 \\
0.33 \\
2000 \\
0.5 \\
9.3 \\
27 \\
17 \\
5.0 \\
0.33 \\
33 \\
13 \\
16 \\
3.3 \\
6.7 \\
0.33 \\
6.7 \\
400 \\
29 \\
29 \\
7.3 \\
27000 \\
22 \\
120\end{array}$ \\
\hline
\end{tabular}




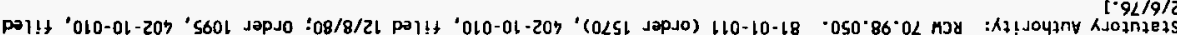

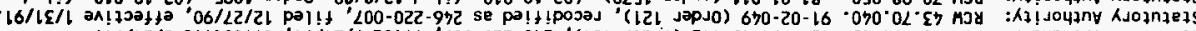

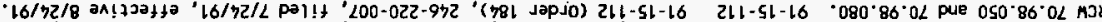

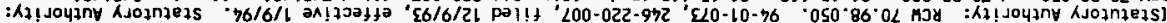

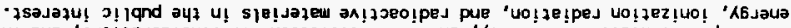

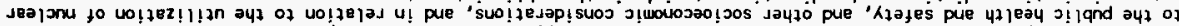

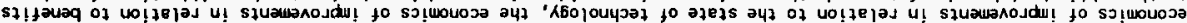

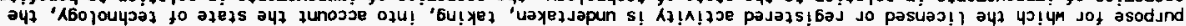

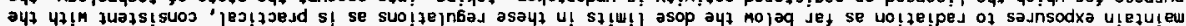

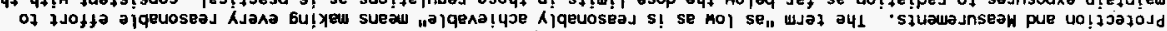

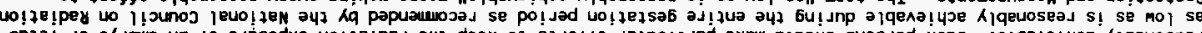

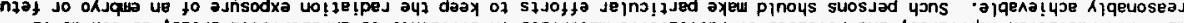

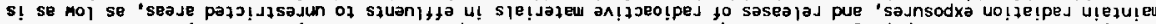

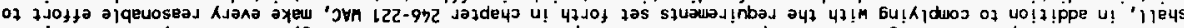

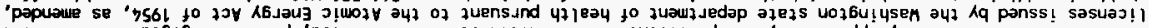

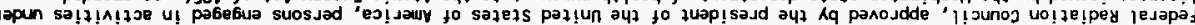

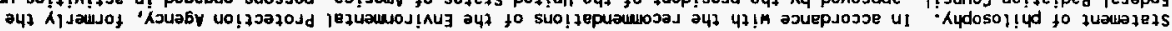

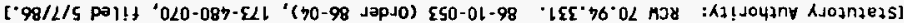

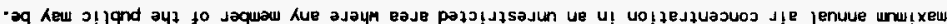

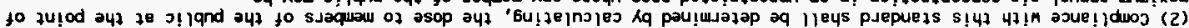
- әүqеi!ns aq ol pau!wuazap

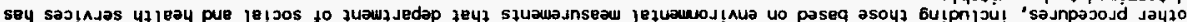
Jo 'sjapoul panoudde saj!njas y1

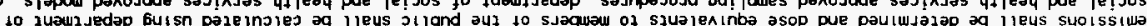

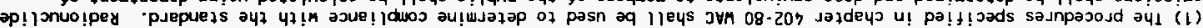

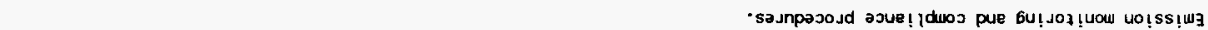

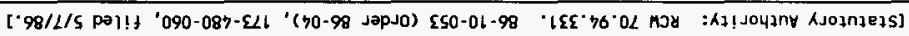

- joJ zu०o uo! ss!wa

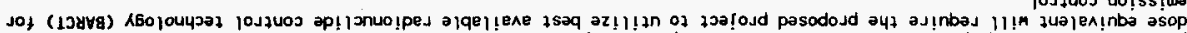

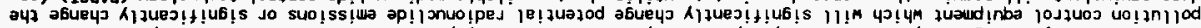

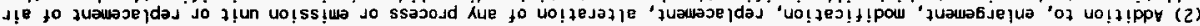

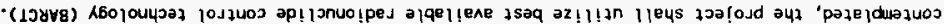

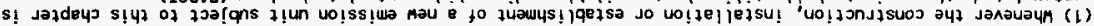

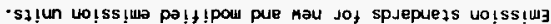


Table 7-1. Constraint Definitions. (100 sheets)

\begin{tabular}{|c|c|}
\hline Constraint Name & Constraint Description \\
\hline VAC246-247-001 & $\begin{array}{l}\text { WAC 246-247-001 Purpose. } \\
\text { The purpose of this chapter is to establ ish application requirements and procedures for the issuance of a radioactive } \\
\text { air emissions licerse and for the regulation of those enissions by the department of heal th (hereinafter referred to as } \\
\text { "the department") to ensure compliance with the standards for radioactive a ir emissions set by the department of ecology } \\
\text { pursuant to RCW } 70.94 .331 \text {. promulgated in chapter }<0<12290>173-480</ D>\text { WAC, and with the rules and regutations of this } \\
\text { chapter. }\end{array}$ \\
\hline WAC246-247-002 & $\begin{array}{l}\text { WAC 246-247-002 Authority. } \\
\text { (1) Rules and regutations set forth herein are adopted and enforced by the department pursuant to the provisions of } \\
\text { chapter } 70.98 \mathrm{RCW} \text { which: } \\
\text { (a) Designate the department as the state's radiation control agency having sale responsibility for the administration } \\
\text { of the regulatory, Licensing, and radiation control provisions of chapter } 70.98 \mathrm{RCW} \text {; } \\
\text { (b) Vest in the department the authority to formulate, adopt, promigate, and repeal codes, rules, and regulations } \\
\text { related to the control of sources of ionizing radiation; } \\
\text { (c) Authorize the department to implement an independent state-wide program to monitor radioactive air enissions from } \\
\text { sources within the state; } \\
\text { (d) Authorize the department to conduct inspections of facilities, both private and public, to determine whether or not } \\
\text { there is compliance with or violation of the provisions of chapter } 70.98 \mathrm{RCH} \text { and rules and regulations issued thereunder; } \\
\text { and } \\
\text { (e) Authorize the department to require registration of sources of ionizing radiation. } \\
\text { (2) In addition, RCW } 70.94 .422 \text { (Washington Clean Air Act) grants to the department the enforcement powers contained in } \\
\text { that chapter. }\end{array}$ \\
\hline
\end{tabular}


Table 7-1. Constraint Definitions. (100 sheets)

\begin{tabular}{|c|c|}
\hline Constraint Name & Constraint Description \\
\hline WAC246-247-010 & 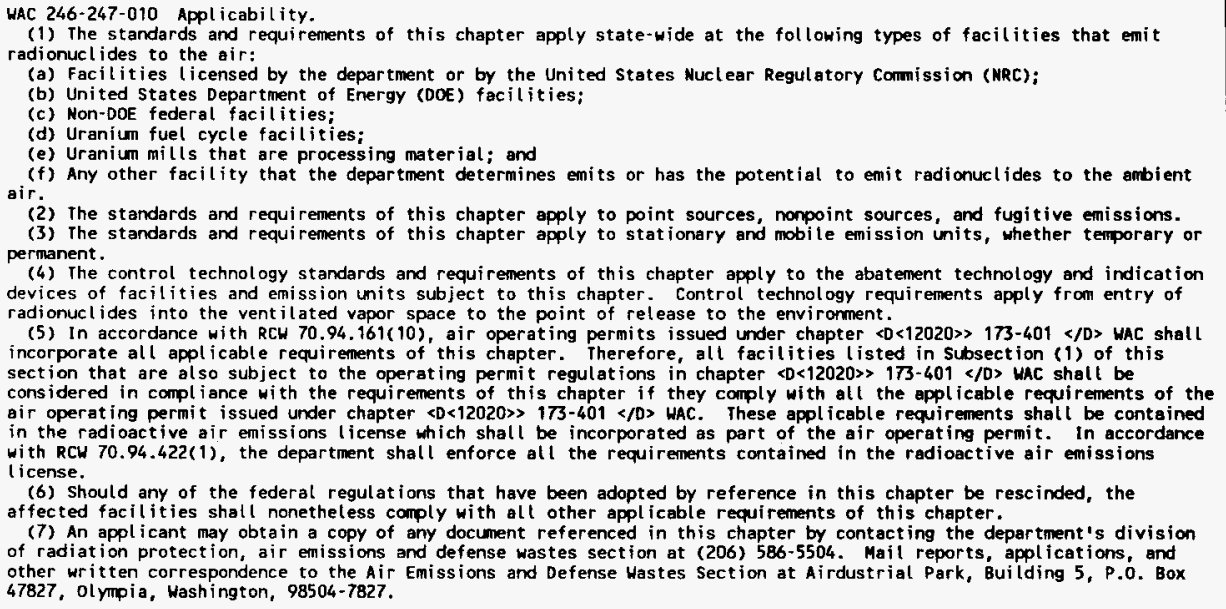 \\
\hline
\end{tabular}


Table 7-1. Constraint Definitions. (100 sheets)

\begin{tabular}{|c|c|}
\hline Constraint Name & Constraint Description \\
\hline HAC246-247-020 & 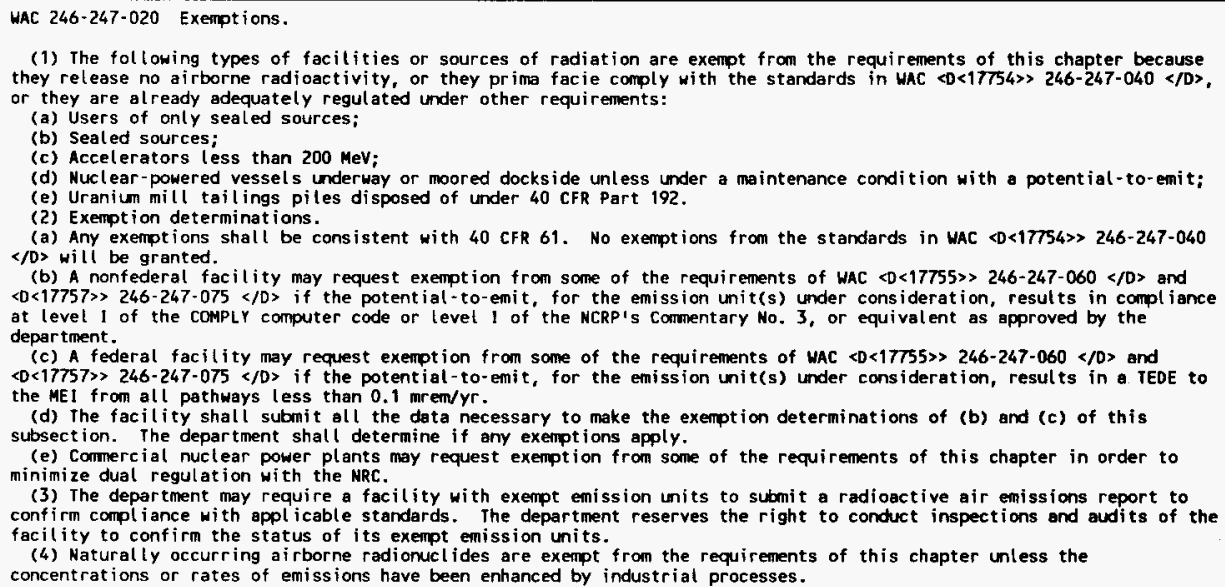 \\
\hline
\end{tabular}


Table 7-1. Constraint Definitions. (100 sheets)

\begin{tabular}{|c|c|}
\hline Constraint Name & Constraint Description \\
\hline MAC246-247-030 (1-5)* & 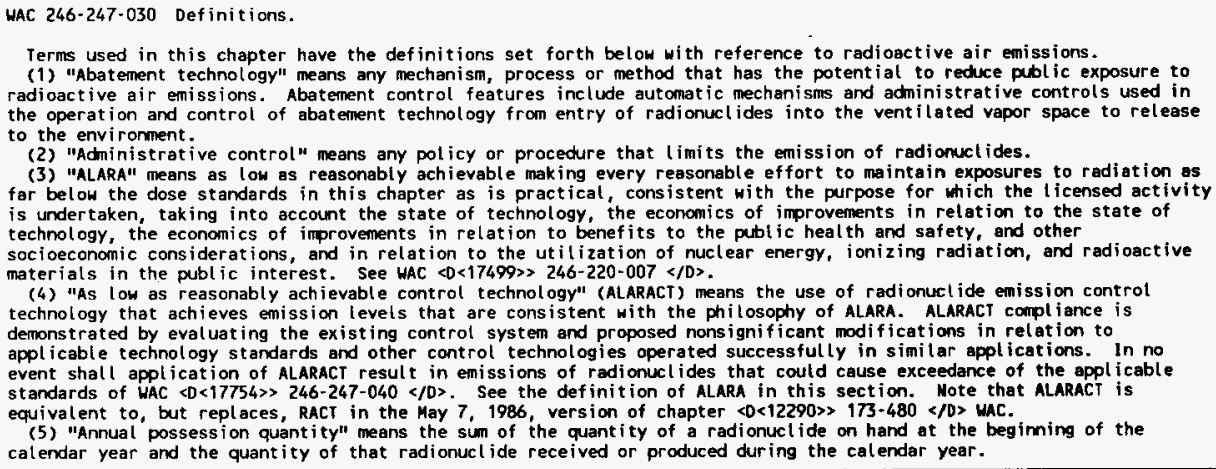 \\
\hline
\end{tabular}


Table 7-1. Constraint Definitions. (100 sheets)

\begin{tabular}{|c|c|}
\hline Constraint Name & Constraint Description \\
\hline WAC246-247.030 (6-11)* & 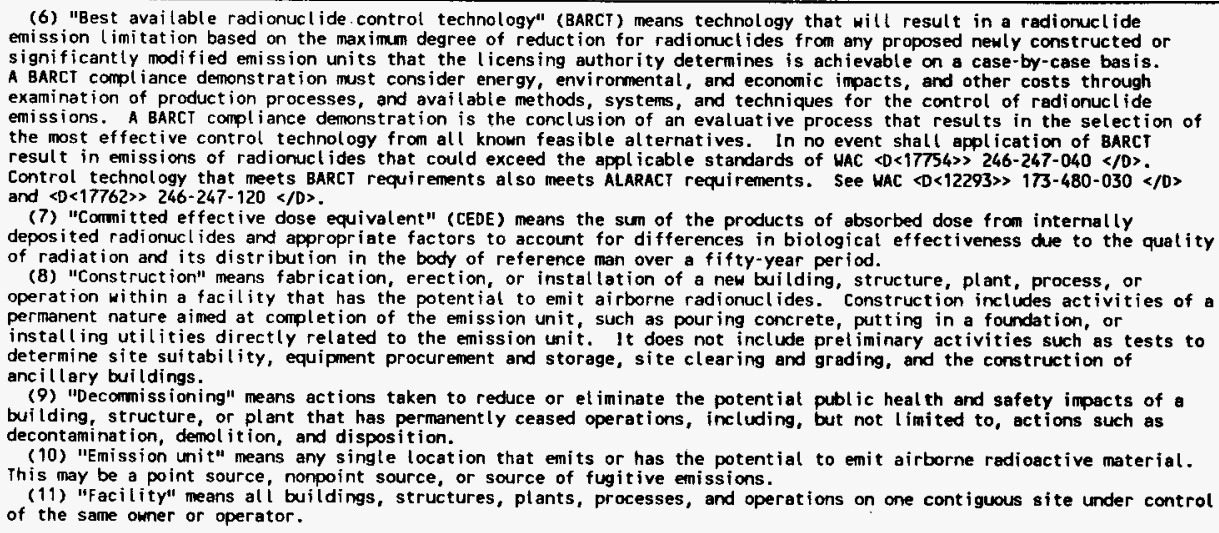 \\
\hline
\end{tabular}


Table 7-1. Constraint Definitions. (100 sheets)

\begin{tabular}{|c|c|}
\hline Constraint Name & Constraint Description \\
\hline $\begin{array}{l}\text { Mac246-247-030 } \\
(12-17)^{\star}\end{array}$ & 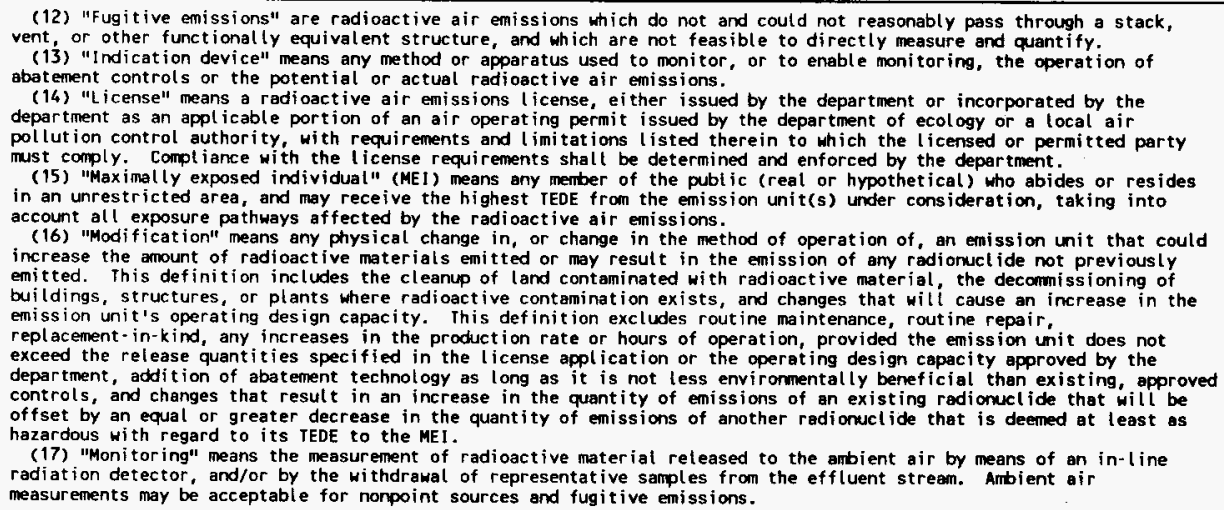 \\
\hline
\end{tabular}


Table 7-1. Constraint Definitions. (100 sheets)

\begin{tabular}{|c|c|}
\hline Constraint Name & Constraint Description \\
\hline $\begin{array}{l}\text { HAC246-247-030 } \\
(18-21)^{*}\end{array}$ & 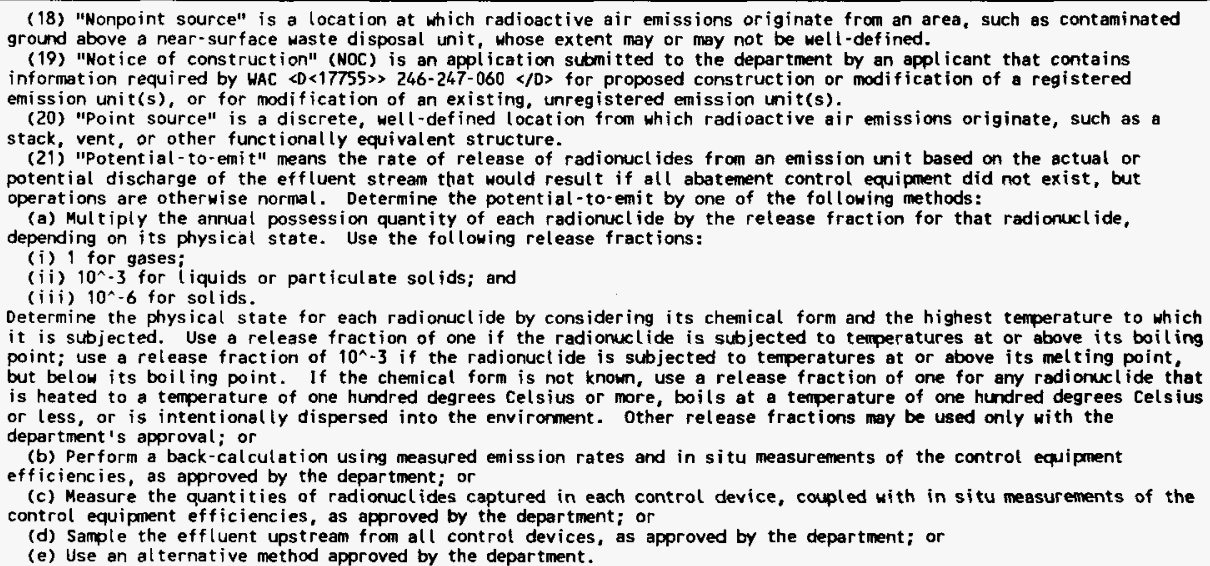 \\
\hline
\end{tabular}


Table 7-1. Constraint Definitions. (100 sheets)

\begin{tabular}{|c|c|}
\hline Constraint Name & Constraint Description \\
\hline WAC246-247-040 & 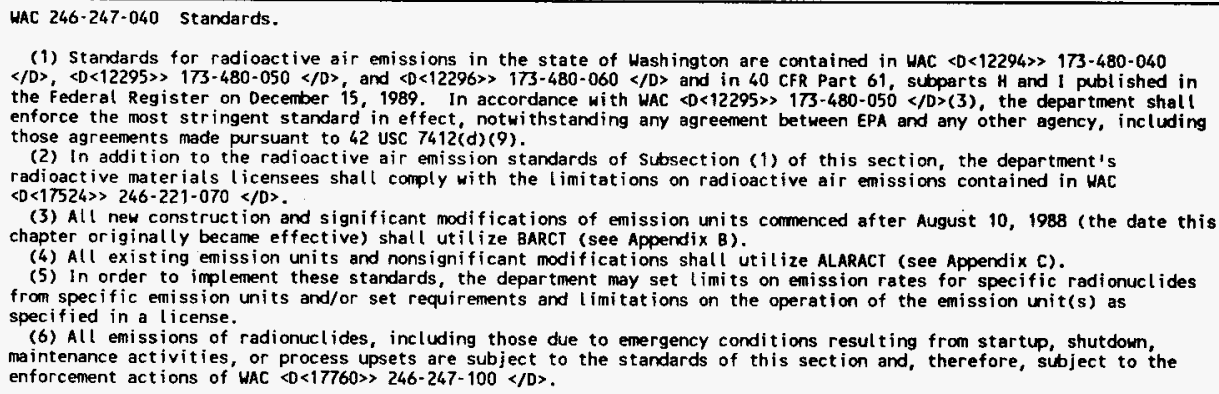 \\
\hline
\end{tabular}


Table 7-1. Constraint Definitions. (100 sheets)

\begin{tabular}{|c|c|}
\hline Constraint Name & Constraint Description \\
\hline Hac246-247-060(1)* & 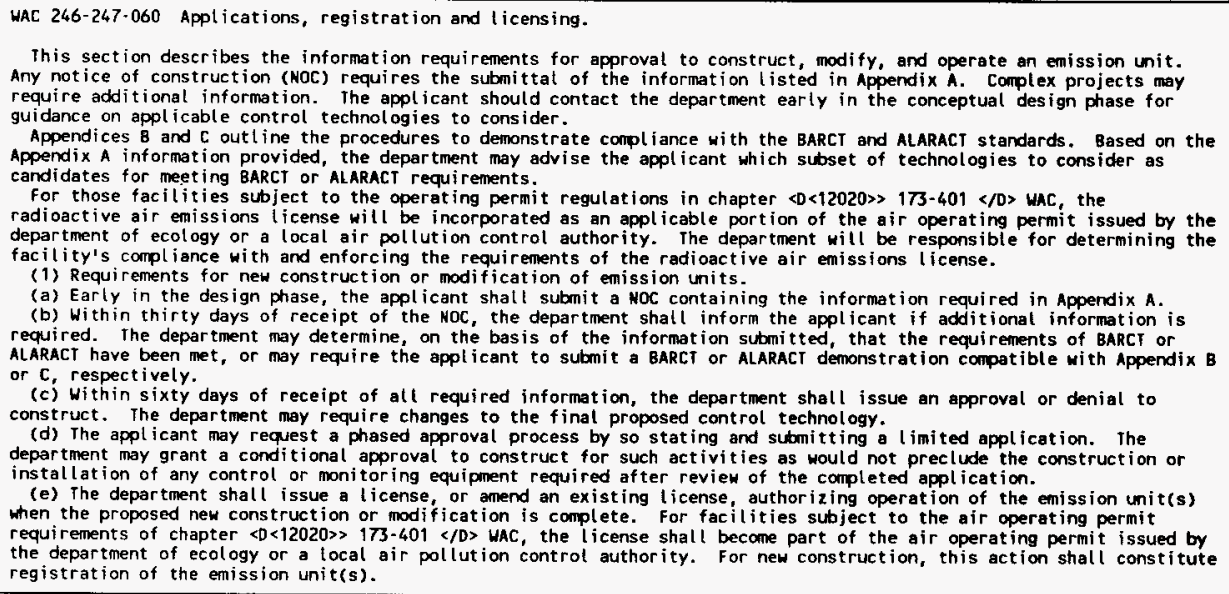 \\
\hline
\end{tabular}


Table 7-1. Constraint Definitions. (100 sheets)

\begin{tabular}{|c|c|}
\hline Constraint Name & Constraint Description \\
\hline HAC246-247-060 (2-5)* & 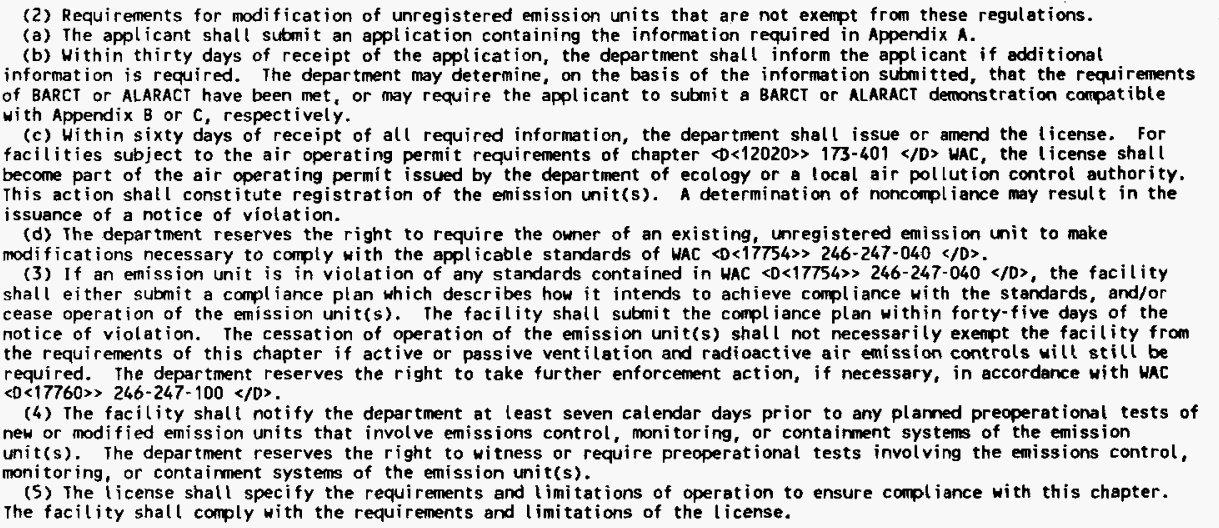 \\
\hline
\end{tabular}


Table 7-1. Constraint Definitions. (100 sheets)

\begin{tabular}{|c|c|}
\hline Constraint Name & Constraint Description \\
\hline HAC246-247-065 & $\begin{array}{l}\text { WAC } 246-247-065 \text { Fees. } \\
\text { (1) All facilities under the authority of this chapter shatl submit fees in accordance with HAC } \$<17834>246-254-160 \\
</ 0>\text { (2) Those facilities required by WAC }<0<17834>246-254-160<10 \times(2) \text { to submit an application fee, shall submit the fee } \\
\text { with the application. }\end{array}$ \\
\hline MAC246-247-075 $(1-8)^{\star}$ & 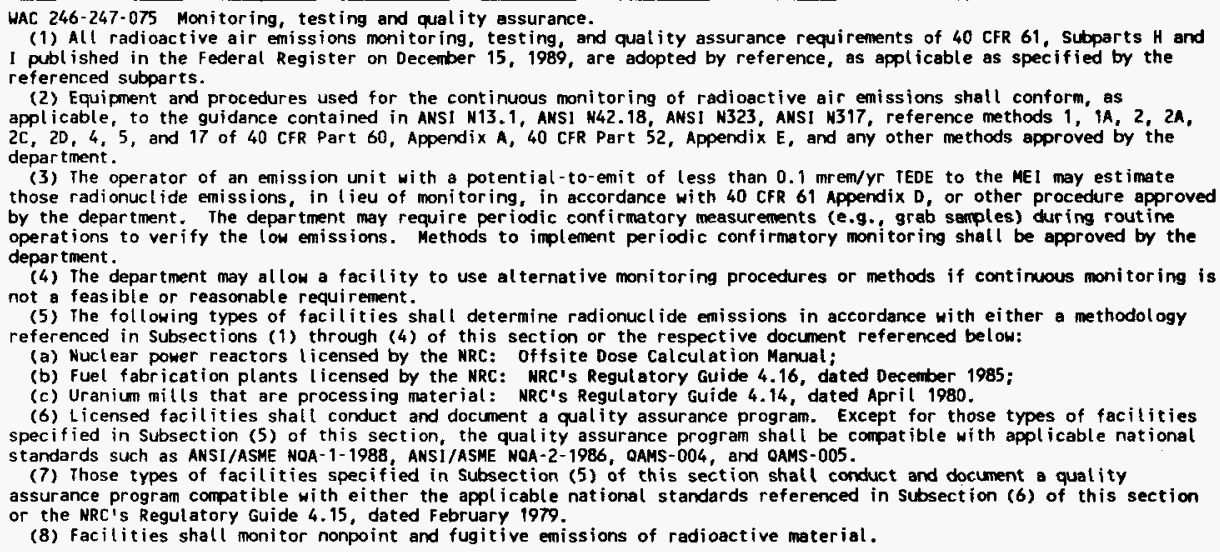 \\
\hline
\end{tabular}


Table 7-1. Constraint Definitions. (100 sheets)

\begin{tabular}{|c|c|}
\hline Constraint Name & Constraint Description \\
\hline HAC246-247-075 $(9-13)^{*}$ & 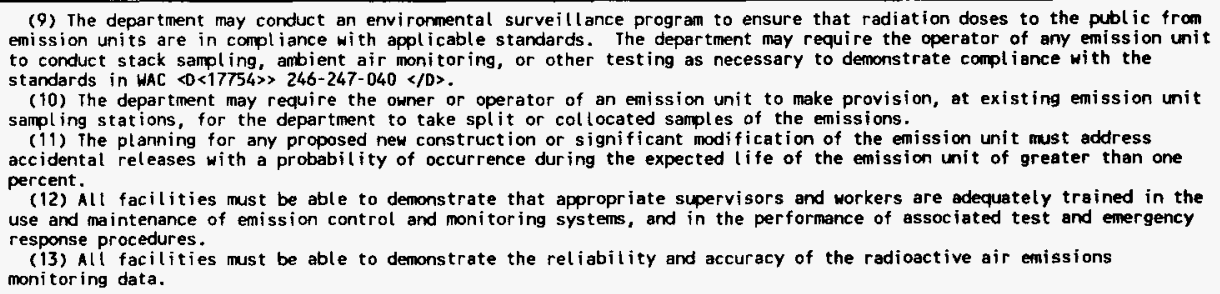 \\
\hline HAC246-247-080 $(1-5)^{*}$ & 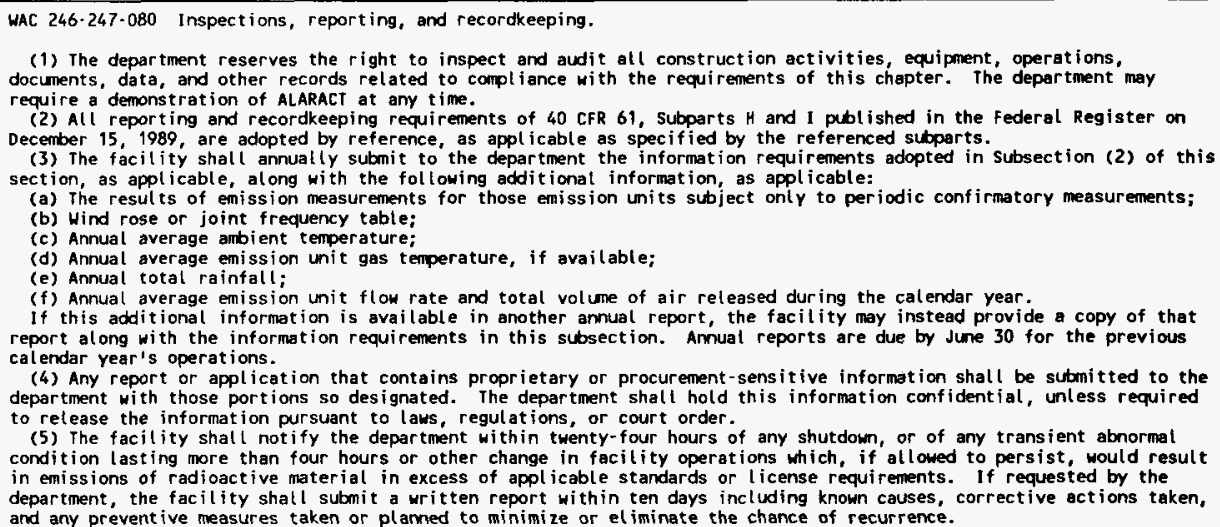 \\
\hline
\end{tabular}


Table 7-1. Constraint Definitions. (100 sheets)

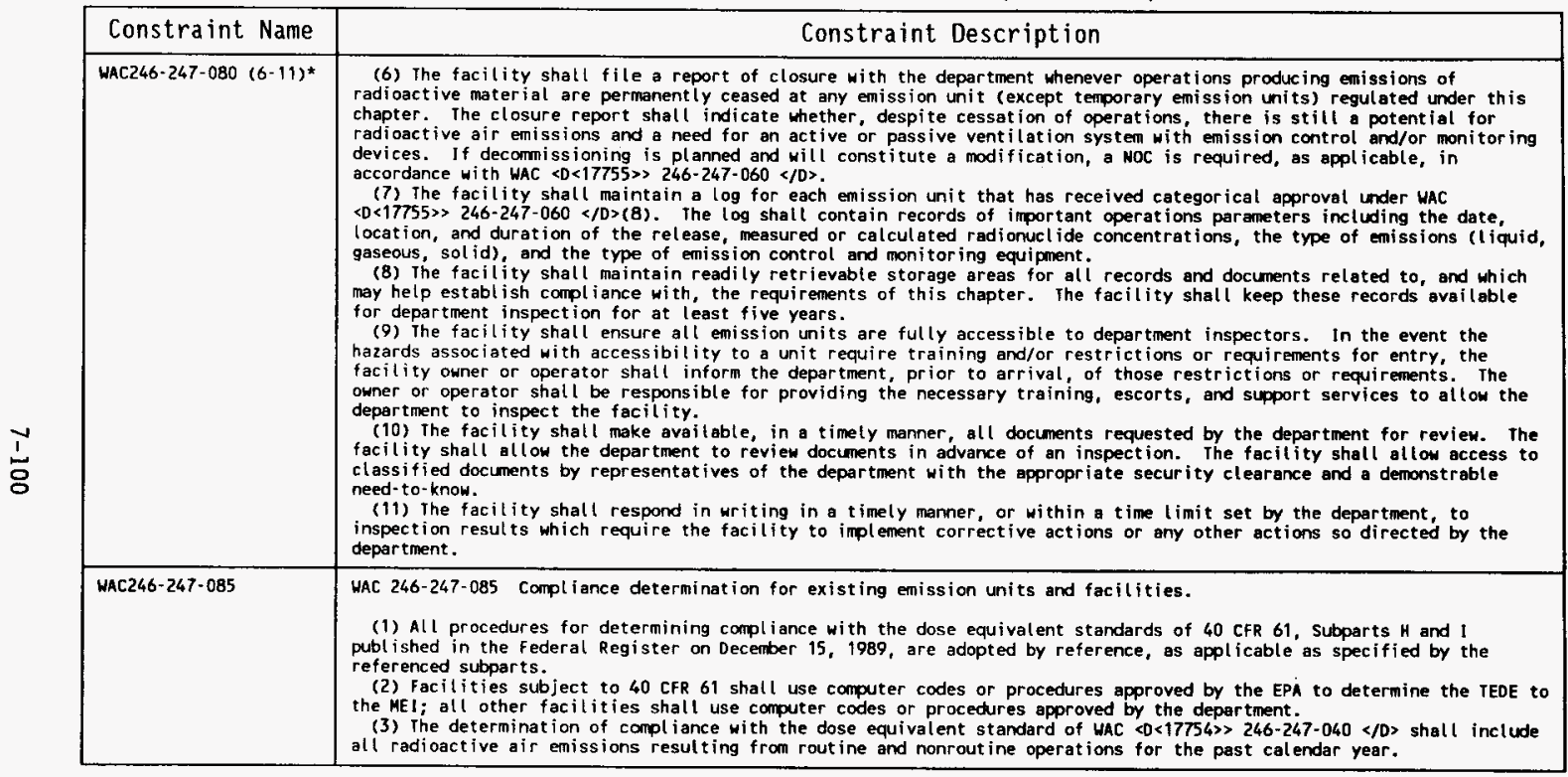


Table 7-1. Constraint Definitions. (100 sheets)

\begin{tabular}{|c|c|}
\hline Constraint Name & Constraint Description \\
\hline WAC $246 \cdot 247-100$ & 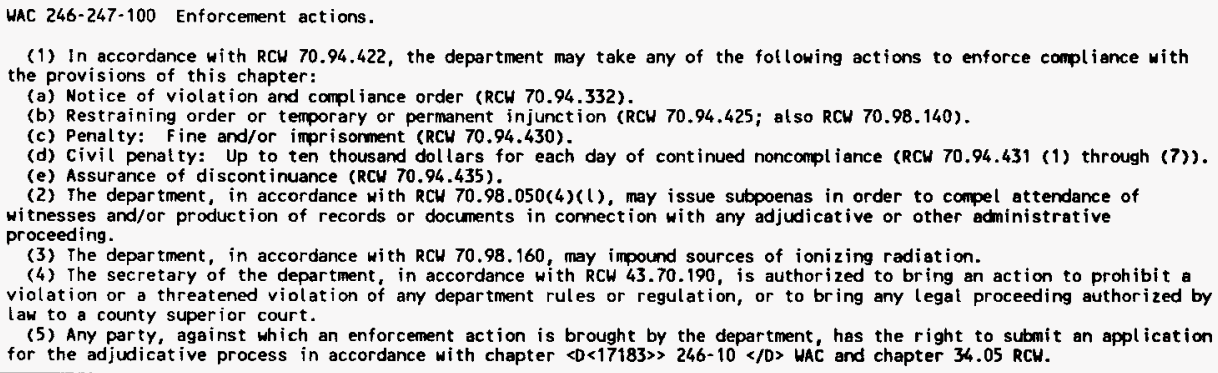 \\
\hline $\begin{array}{l}\text { Worker Radiological } \\
\text { Safety: Hanford Site } \\
\text { Radiological Control } \\
\text { Manual, Chapter i } \\
\text { Part 1, Section } 111 \\
\text { and section } 112\end{array}$ & 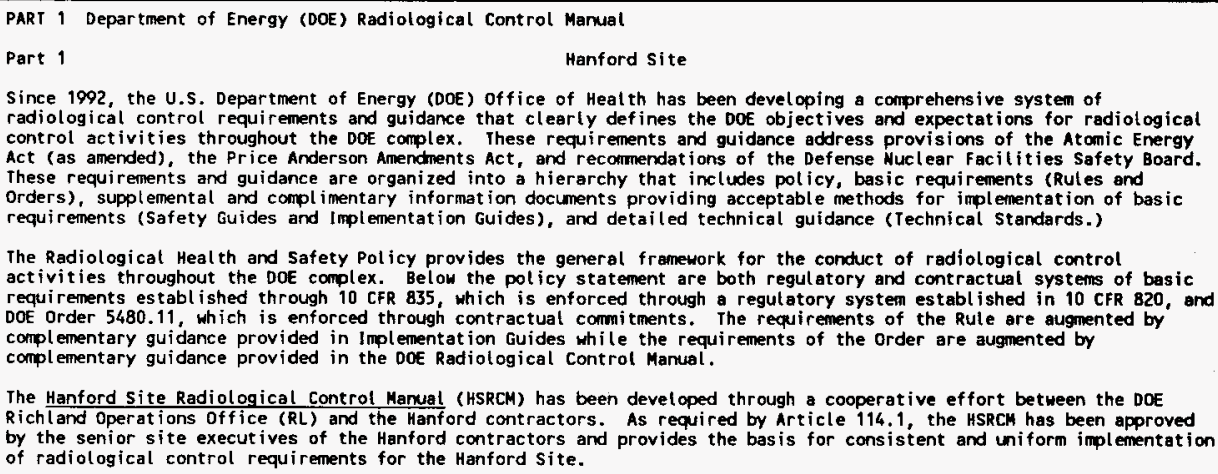 \\
\hline
\end{tabular}

tSpl it out from parent requi rement in THRS database, to fit the available space. Allocation is based on parent requirement. 
Table 7-2. Performance Requirement Definitions. (13 sheets)

\begin{tabular}{|c|c|}
\hline Performance Requirement Name & Performance Requirement Description \\
\hline 200 Area IEDF Haste Acceptance Criteris & $\begin{array}{l}\text { The dispositioned aqueous waste must meet the acceptance criteria and associated administrative } \\
\text { procedures of the } 200 \text { Area Treated Effluent Disposal Facility. }\end{array}$ \\
\hline ALARA-Design Compliance & 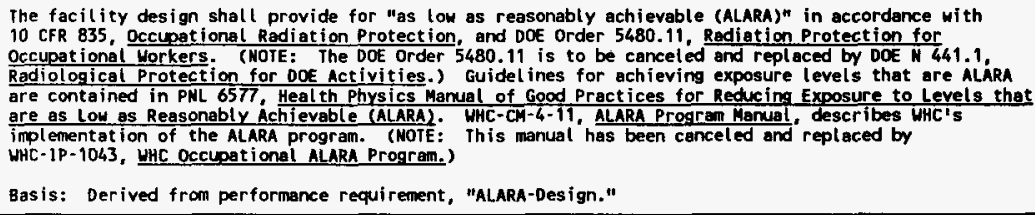 \\
\hline Cesium Product storage Requirements & The conditions for safe handling and storage of the cesium product shall be provided by the proctucer. \\
\hline Documentation & $\begin{array}{l}\text { Records, documents, and document control pertinent to design functions shall be in accordance with } \\
\text { ASME-NAA-1-1994-IA, DOE } 5500.7 \mathrm{~b} \text {, DOE }-5480 . \mathrm{CM} \text {, and ANSI/ANS-3.2-88. }\end{array}$ \\
\hline DOE/RL 93-08 Hanford Mission Plan & The 200 Area is a limited use area. \\
\hline
\end{tabular}


Table 7-2. Performance Requirement Definitions. (13 sheets)

\begin{tabular}{|c|c|}
\hline Performance Requirement Name & Performance Requirement Description \\
\hline Enviromental Conditions & 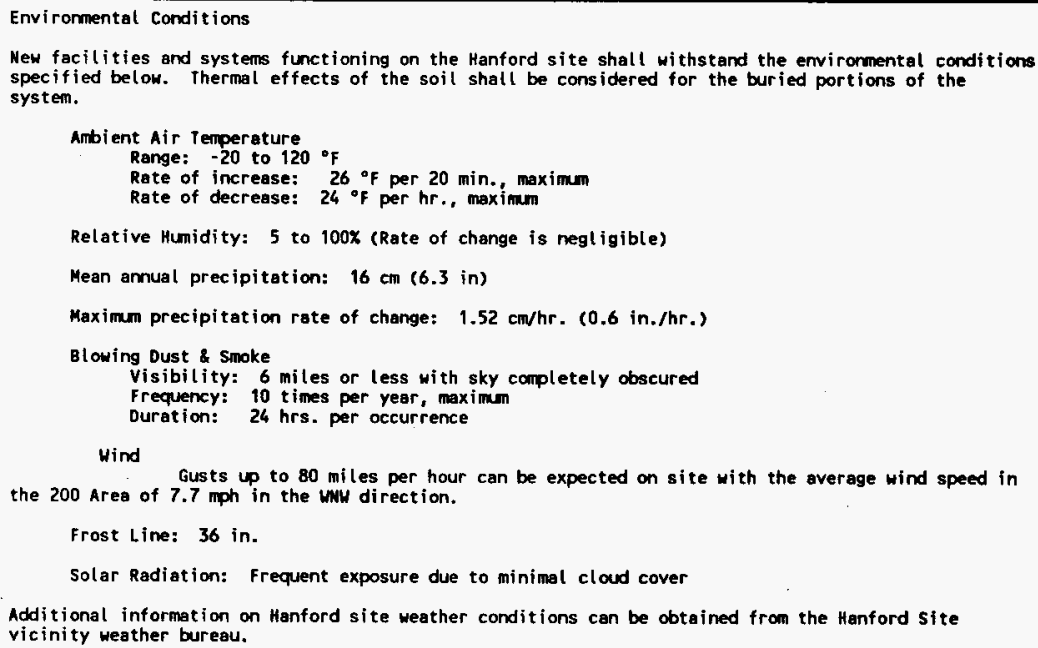 \\
\hline
\end{tabular}


Table 7-2. Performance Requirement Definitions. (13 sheets)

\begin{tabular}{|c|c|}
\hline Performance Requirement Name & Performance Requirement Description \\
\hline Estimated THRS Project Schedule & 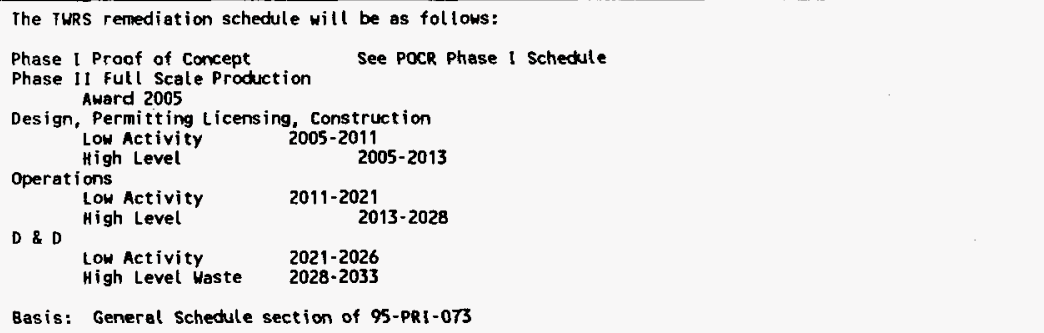 \\
\hline Fission Product Inter im Storage & $\begin{array}{l}\text { Fission prochucts separated shall be returned in a waste form and canister suitable for long-term } \\
\text { storage. The storage duration is } T B D \text {. }\end{array}$ \\
\hline Hazardous Waste Determination & 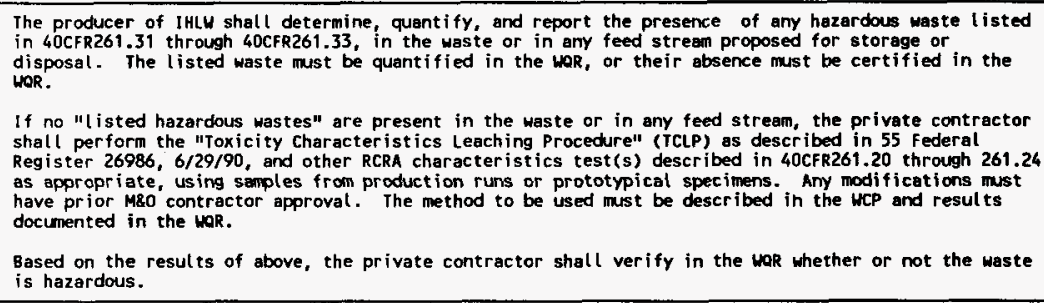 \\
\hline HLW Constituents Limitations & 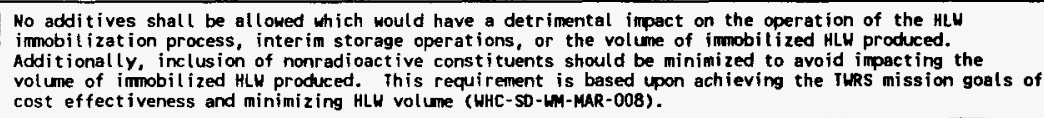 \\
\hline HLW Glass Product Rework & $\begin{array}{l}\text { On a case by case basis, out-of-specification HLH glass product will either be reworked, overpacked, or } \\
\text { a waiver will be sought. }\end{array}$ \\
\hline
\end{tabular}


Table 7-2. Performance Requirement Definitions. (13 sheets)

\begin{tabular}{|c|c|}
\hline Performance Requirement Name & Performance Requirement Description \\
\hline HLW Glass Naste Oxide Loading & $\begin{array}{l}\text { The volume of HLW glass shall be minimized for a given waste feed. } \\
\text { Basis: The decrease in volume of HLW glass produced by increasing the waste oxide loading from } 25 x \text { to } \\
45 x \text {, resul ts in savings to the program of more than } \$ 2 \text { billion in vitrification and repository disposal } \\
\text { costs (Feed Processability study. WHC-SP-1143) }\end{array}$ \\
\hline HLW Vitrification Production Capacity & 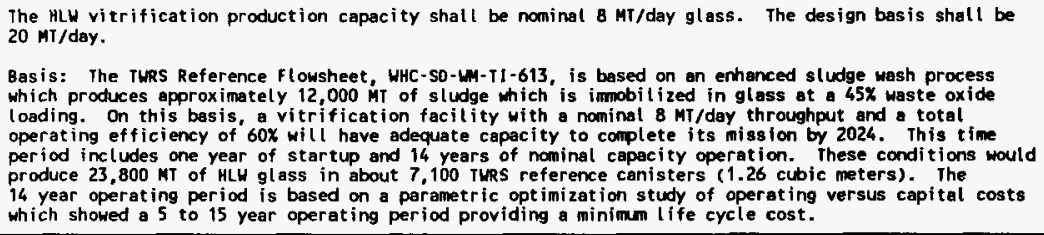 \\
\hline $\begin{array}{l}\text { Monitoring of Solidified High-Level } \\
\text { Waste Packages }\end{array}$ & $\begin{array}{l}\text { Containerized immobilized HLH/TRU waste and dispositioned CS/Sr capsules shall be monitored during the } \\
\text { period of interim storage to determine compliance Hith the geologic repository waste acceptance } \\
\text { criteria allocated to interfaces IHLH for Shipment, ITRU for Shipment, and Dispositioned Cs/Sr Capsules } \\
\text { for Shipment. If an immobilized HLW immobilized IRU waste, or dispositioned capsule container is } \\
\text { determined to not comply with the allocated requirements for geologic repository disposal, the suspect } \\
\text { container will be evaluated for re-work or acceptance by the geological repository as a non-standard } \\
\text { waste form. }\end{array}$ \\
\hline
\end{tabular}


Table 7-2. Performance Requirement Definitions. (13 sheets)

\begin{tabular}{|c|c|}
\hline Performance Requirement Name & Performance Requirement Description \\
\hline $\begin{array}{l}\text { Notification of Startup, Shutdown, or } \\
\text { other Change That May Affect Emissions } \\
\text { Measurement }\end{array}$ & 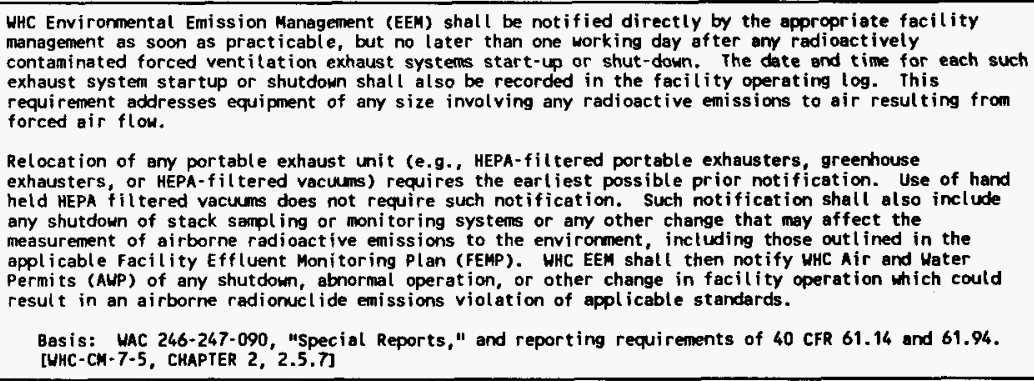 \\
\hline $\begin{array}{l}\text { Onsite Transport of Radioactive } \\
\text { Materials }\end{array}$ & $\begin{array}{l}\text { The transport of onsite radioactive solid waste shall be in accordance with DOE-95-SWT-186 and CH-2-14 } \\
\text { "Hazardous Material Packaging and Shipping", based upon DOE Order } 460.1 \\
\text { BAsIS: DOE-95-5WT-186 }\end{array}$ \\
\hline
\end{tabular}


Table 7-2. Performance Requirement Definitions. (13 sheets)

\begin{tabular}{|c|c|}
\hline Performance Requirement Name & Performance Requirement Description \\
\hline $\begin{array}{l}\text { Preservation of Producer Generated } \\
\text { ol idified HLH and TRU Waste } \\
\text { Certification Status }\end{array}$ & 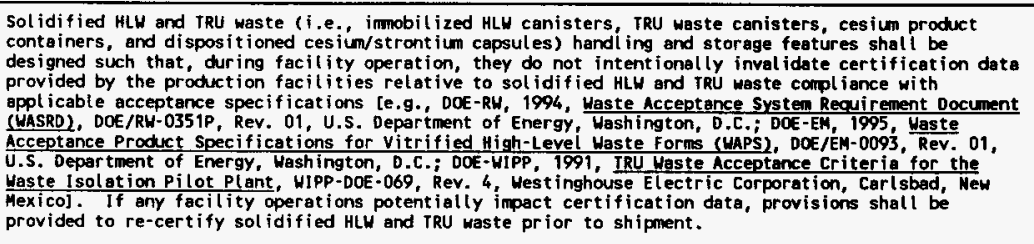 \\
\hline Product Verification & Verification of products for compliance with requirements may be audited by DOE at DOE's discretion. \\
\hline
\end{tabular}


Table 7-2. Performance Requirement Definitions. (13 sheets)

\begin{tabular}{|c|c|}
\hline Performance Requirement Name & Performance Requirement Description \\
\hline Oual ity Assurance Plan & 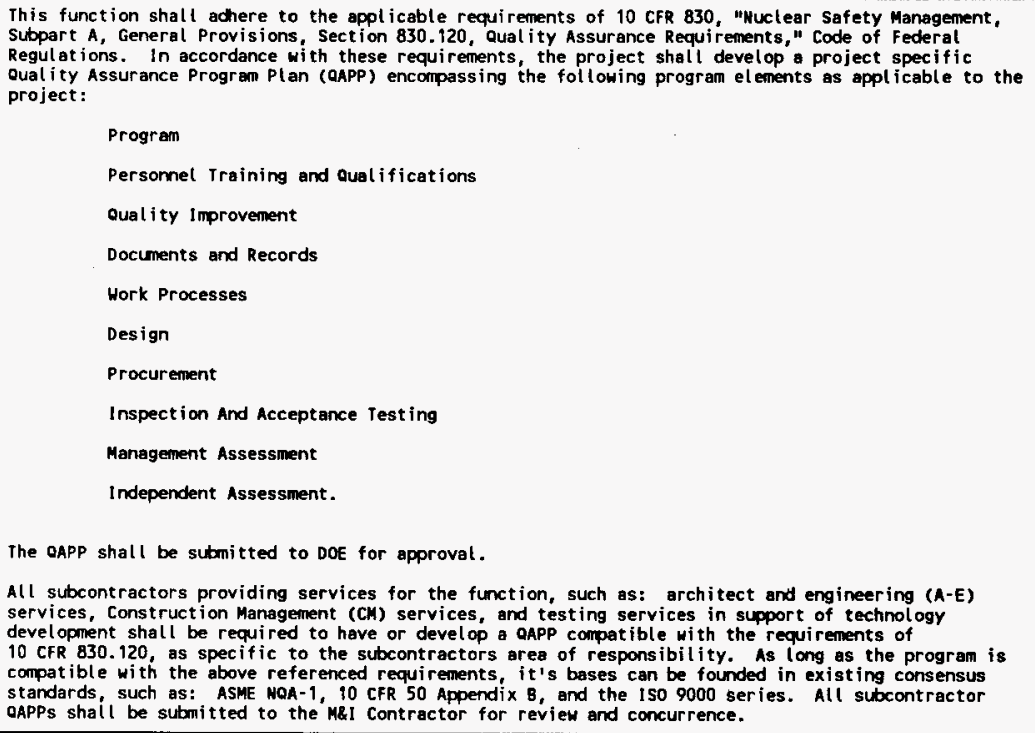 \\
\hline Ouantity of IHLW for Storage & $\begin{array}{l}\text { The est imated quantity of immobil ized HLW gl ass produced is not expected to exceed } 2.4 E+04 \text { metric tons } \\
(-9.0 \mathrm{E}+03 \text { cubic meters) at a } 45 \mathrm{wtZ} \text { waste oxide loading or } 4.3 \mathrm{E}+04 \text { metric tons }(-1.6 \mathrm{E}+04 \text { cubic meters) } \\
\text { at a } 25 \text { wtx waste oxide loading. }\end{array}$ \\
\hline Quantity of ITRU Waste for Storage & $\begin{array}{l}\text { The maximum quantity of immobilized IRU glass produced shall not exceed } 8.8 E+02 \text { metric tons ( } 3.3 E+02 \\
\text { cubic meters) at a } 45 \text { wty waste oxide loading or } 1.6 E+03 \text { metric tons }(-5.9 E+02 \text { cubic meters) at a } 25 \text { wtx } \\
\text { waste oxide loading. }\end{array}$ \\
\hline
\end{tabular}


Table 7-2. Performance Requirement Definitions. (13 sheets)

\begin{tabular}{|c|c|}
\hline Performance Requirement Name & Performance Requirement Description \\
\hline Quantity of Packaged Capsules & $\begin{array}{l}\text { The est imated quantity of standard HLH canisters } 0.62 \mathrm{~m}^{3} \text { per canister) prochced from packaging Cs/sr } \\
\text { capsules is }-400 \text { standard canisters, based upon packaging } 6 \text { capsules end to end per canister. }\end{array}$ \\
\hline Quantity of Waste Canisters & $\begin{array}{l}\text { The expected volume of immobilized HLW/IRU waste is }-9,060 \mathrm{~m}^{3} \text { at } 45 \mathrm{wtZ} \text { waste oxide (orme } 1995 \text { ) loading } \\
\text { or }-16,300 \mathrm{~m}^{3} \text { at } 25 \mathrm{wtZ} \text { waste oxide loading. } \\
\text { If packaged in the standard HLW canister }\left(0.62 \mathrm{~m}^{3} \text { per canister), }-14,600 \text { to } 26,300 \text { canisters will be }\right. \\
\text { produced. An additional }-400 \text { standard HLW canisters would be produced from overpackaging cesium and } \\
\text { strontium capsules. } \\
\text { The interim store immobitized waste function must have sufficient capacity to receive and interim store } \\
\text { this projected quantity of standard canisters. }\end{array}$ \\
\hline $\begin{array}{l}\text { Reporting of Canister Material Removed } \\
\text { During Decontamination }\end{array}$ & $\begin{array}{l}\text { The producer of HLW shatl report an estimate of the amount of canister material (particularly wall } \\
\text { thickness) removed during decontemination of the canister surface. }\end{array}$ \\
\hline Safety Class & $\begin{array}{l}\text { The degree of redumdancy, rel iability, and availability shall correspond to a systematically determined } \\
\text { safety classification for all systems, structures, and components. } \\
\text { Basis: DOE } 6430.1 \mathrm{~A}\end{array}$ \\
\hline Shielding Criteria & $\begin{array}{l}\text { Guidel ines for radiological design are provided in UHC-SD-GN-DGS-30011, Radiological Design Guide. The } \\
\text { shielding design criteria in UHC-SD-GN-DGS-30011. Section } 7.0 \text {, shall be used to determine the shielding } \\
\text { requirements of different areas in the facility. Shielding shall be designed to limit the total whole } \\
\text { body dose to less than } 5 \text { mSV per year. }\end{array}$ \\
\hline
\end{tabular}


Table 7-2. Performance Requirement Definitions. (13 sheets)

\begin{tabular}{|c|c|}
\hline Performance Requirement Name & Performance Requirement Description \\
\hline $\begin{array}{l}\text { Site Location - Cs/Sr Capsules Interim } \\
\text { Storage }\end{array}$ & $\begin{array}{l}\text { The capsule storage facility shall be co-located with the Phase II HLW interim storage facility to } \\
\text { maximize the use of common support facility services. The facility will be located near the tims } \\
\text { processing complex within the } 200 \text { East Area. } \\
\text { Basis: The IURs facility configuration Study finds that there is a significant savings associated with } \\
\text { the sharing of facilities and equipment. }\end{array}$ \\
\hline Solid Radioactive Haste Transfer & $\begin{array}{l}\text { Transfer of sol id radioactive waste to the Hanford site Sol id Waste program for dispositioning shall be } \\
\text { in accordance with criteria specified in the Hanford Site Sol id Waste Acceptance Criteria, UHC-EP-0063, } \\
\text { DOE } 1540.1 \text { Material, Transportation and Traffic Management, and DOE } 95 \text {-SWT-186 for on site shipment. }\end{array}$ \\
\hline $\begin{array}{l}\text { Solidified HLW and TRU Waste Interim } \\
\text { storage facility Design Life }\end{array}$ & 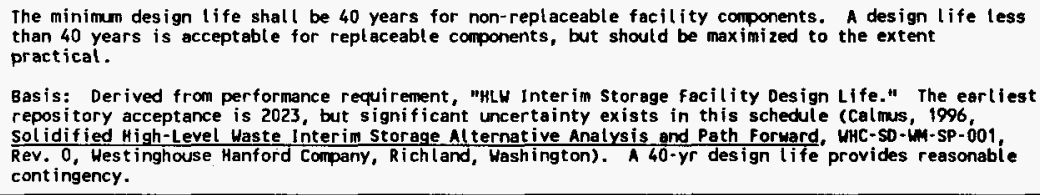 \\
\hline $\begin{array}{l}\text { Solidified HLW and TRU Waste Interim } \\
\text { Storage Schedule }\end{array}$ & 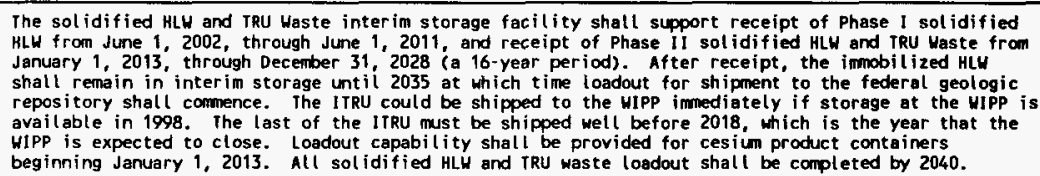 \\
\hline
\end{tabular}


Table 7-2. Performance Requirement Definitions. (13 sheets)

\begin{tabular}{|c|c|}
\hline Performance Requirement Name & Performance Requirement Description \\
\hline Storage Capacity/Availabitity & $\begin{array}{l}\text { The interim storage facility shall support the scheduled operation of the HLW vitrification facility } \\
\text { and capsule overpack facility. }\end{array}$ \\
\hline Tine Temperature Transformation Data & $\begin{array}{l}\text { The producer of IHLW shall provide the Time Temperature Transformation diagrams and data for the } \\
\text { canistered waste form. }\end{array}$ \\
\hline
\end{tabular}


Table 7-2. Performance Requirement Definitions. (13 sheets)

\begin{tabular}{|c|c|}
\hline Performance Requirement Name & Performance Requirement Description \\
\hline Untreated Liquid Effluents (1)* & 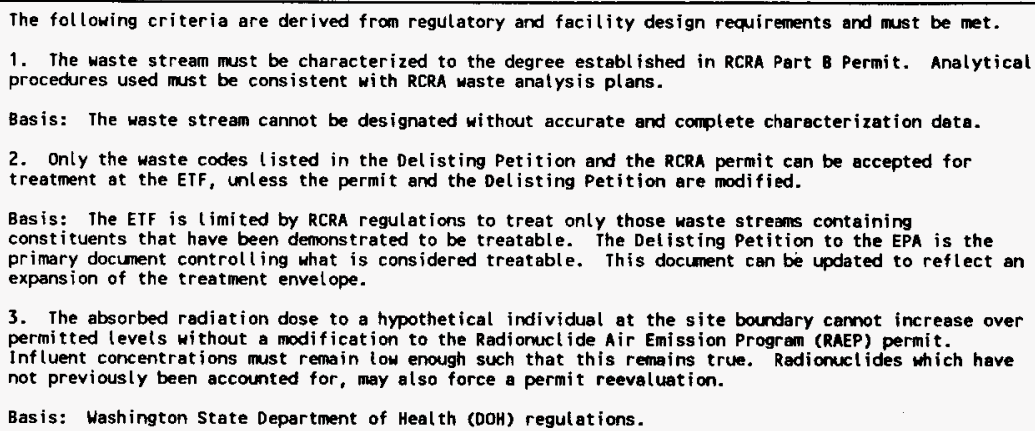 \\
\hline
\end{tabular}


Table 7-2. Performance Requirement Definitions. (13 sheets)

\begin{tabular}{|c|c|}
\hline Performance Requirement Name & Performance Requirement Description \\
\hline Untreated Liquid Effluents (2)* & 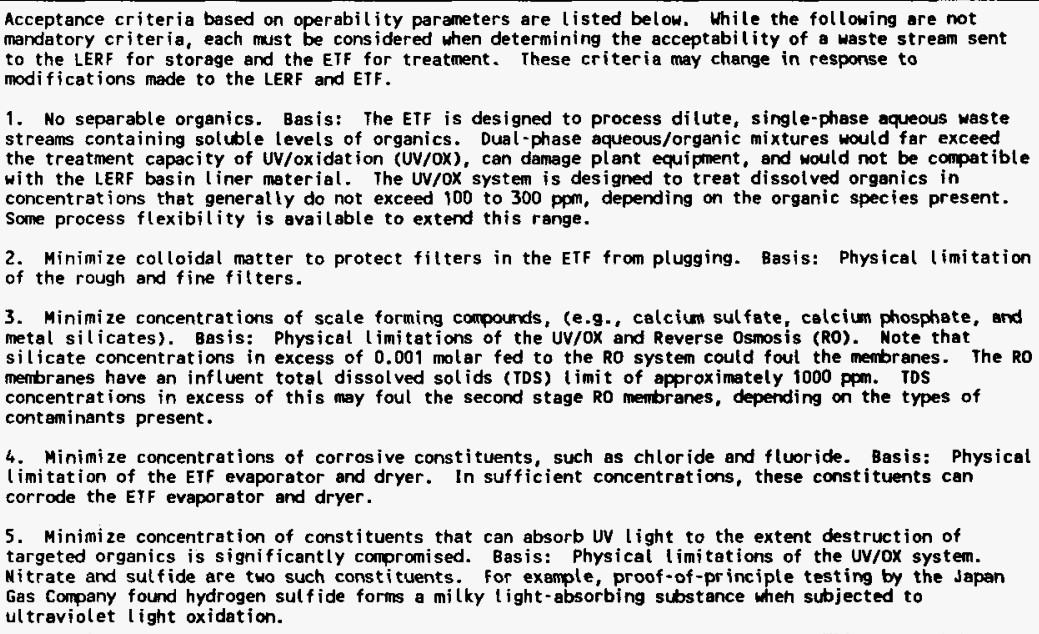 \\
\hline Untreated Liquid Effluents (3)* & 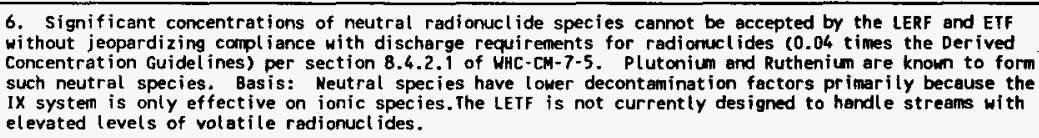 \\
\hline
\end{tabular}


Table 7-2. Performance Requirement Definitions. (13 sheets)

\begin{tabular}{|c|c|}
\hline Performance Requirement Name & Performance Requirement Description \\
\hline Waste Acceptance Process Activity & 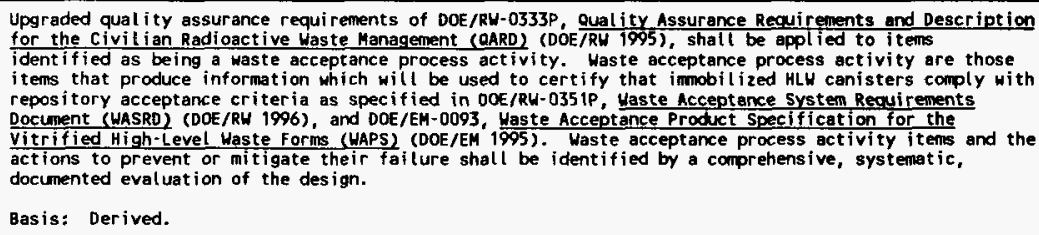 \\
\hline Worker Occupational Safety & $\begin{array}{l}\text { TURS activities shall conform to } 29 \text { CFR } 1910 \text { and DOE } 5483.1 \text { o occupational Safety and Heal th } \\
\text { Administration (OSHA) Program at Goverment oumed contractor operated facilities. }\end{array}$ \\
\hline
\end{tabular}

*Sptit out from parent requirement in THRS database, to fit available space. Allocation is based on parent requirement. 


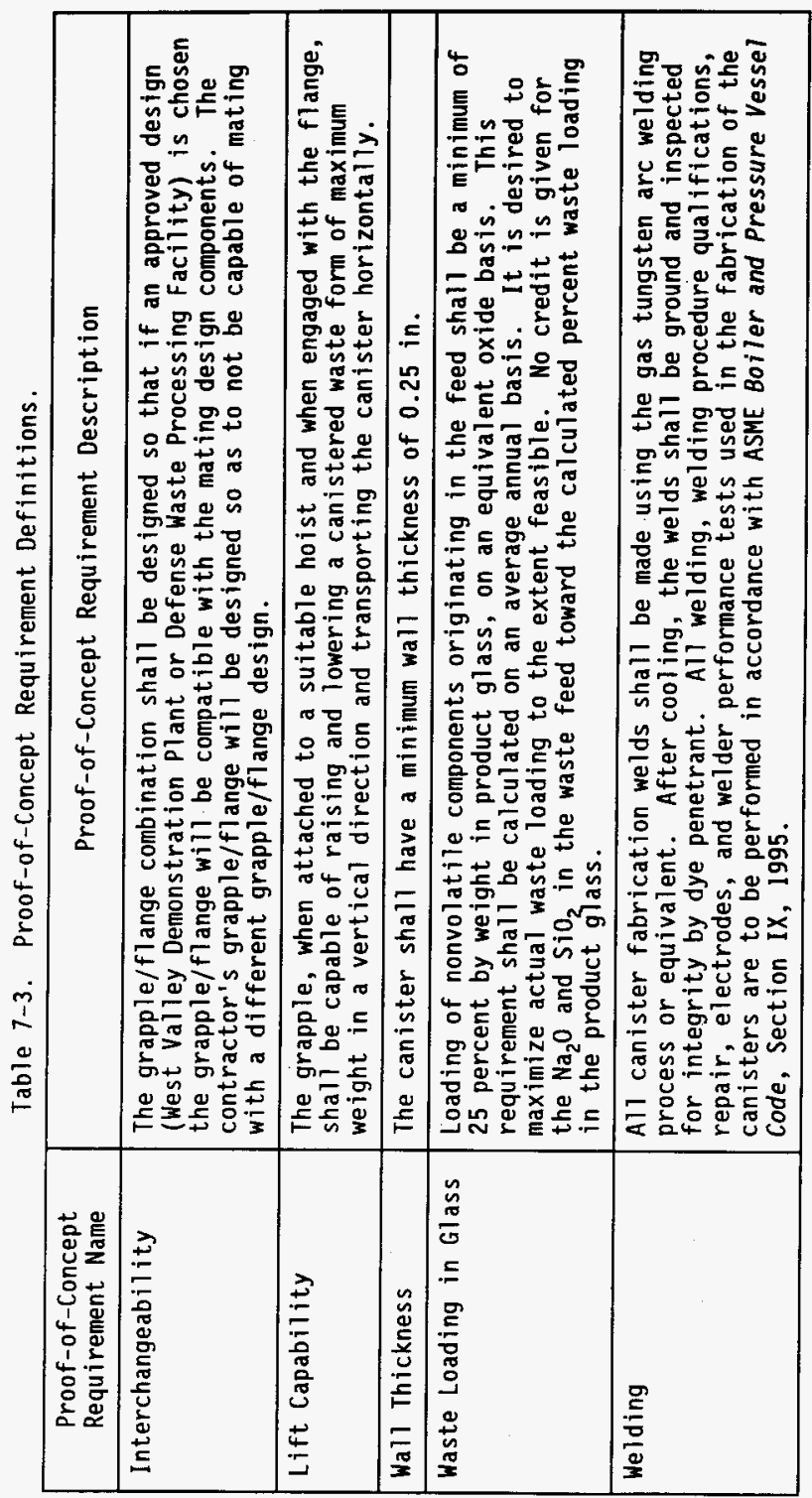


WHC-SD-WM-FRD-027 Rev. 0

This page intentionally left blank. 


\subsection{REFERENCES}

10 CFR 830, "Nuclear Safety Management," Code of Federal Regulations, as amended.

10 CFR 835, "Occupational Radiation Protection," Code of Federal Regulations, as amended.

40 CFR 50, "National Primary and Secondary Ambient Air Quality Standards," Code of Federal Regulations, as amended.

40 CFR 61, "National Emission Standards for Hazardous Air Pollutants," Code of Federal Regulations, as amended.

40 CFR 191, "Environmental Radiation Protection Standards for Management and Disposal of Spent Nuclear Fuel, High Level and Transuranic Radioactive Wastes," Code of Federal Regulations, as amended.

40 CFR 261, "Identification and Listing of Hazardous Waste," Code of Federal Regulations, as amended.

40 CFR 252, "Standards Applicable to Generators of Hazardous Waste," Code of Federal Regulations, as amended.

40 CFR 264, "Standards for Owners and Operators of Hazardous Waste Treatment, Storage, and Disposal Facilities," Code of Federal Regulations, as amended.

ANSI/ASME, 1986, Quality Assurance Requirements for Nuclear Power Plants, ANSI/ASME NQA-2-1986, American National Standards Institute, American Society of Mechanical Engineers, New York, New York.

ASME, 1995, Boiler and Pressure Vessel Code, American Society of Mechanical Engineers, New York, New York.

Boomer, K. D., 1994, Tank Waste Remediation System Facility Configuration Study, WHC-SD-WM-ES-295, Rev. 0, Westinghouse Hanford Company, Richland, Washington.

Calmus, R. B., 1996, Immobilized High-Level Waste Interim Storage Alternative Evaluation and Path Forward Recommendation, WHC-SD-WM-SP-011, Rev. 0, Westinghouse Hanford Company, Richland, Washington

Clean Air Act of 1955, as amended, 42 USC 7401, et seq.

DOD, 1989, Human Engineering Design Criteria for Military Systems, Equipment, and Facilities, Mil-Std 1472d, U.S. Department of Defense, Washington, D.C.

DOE, 1984, Environmental Protection, Safety and Health Protection Standards, DOE Order 5480.4, U.S. Department of Energy, Washington, D.C. 
WHC-SD-WM-FRD-027 Rev. 0

DOE, 1988, Radioactive Waste Management, DOE Order 5820.2A, U.S. Department of Energy, Washington, D.C.

DOE, 1990, Conduct of Operations Requirements for DOE Facilities, DOE Order 5480.19, U.S. Department of Energy, Washington, D.C.

DOE, 1991, Nuclear Safety Policy, SEN-35-91, U.S. Department of Energy, Washington, D.C.

DOE, 1991, Unreviewed Safety Questions, DOE Order 5480.21, U.S. Department of Energy, Washington, D.C.

DOE, 1992, Technical Safety Requirements, DOE Order 5480.22, U.S. Department of Energy, Washington, D.C.

DOE, 1992, Nuclear Criticality Safety, DOE Order 5480.24, U.S. Department of Energy, Washington, D.C.

DOE, 1992, Nuclear Safety Analysis Reports, DOE Order 5480.23, U.S. Department of Energy, Washington, D.C.

DOE, 1992, Natural Phenomena Hazards Mitigation, DOE Order 5480.28, U.S. Department of Energy, Washington, D.C.

DOE, 1993, Fire Protection, DOE Order 5480.7A, U.S. Department of Energy, Washington, D.C.

DOE, 1994, Maintenance Management Program, DOE Order 4330.4B, U.S. Department of Energy, Washington, D.C.

DOE, 1995, Packaging and Transportation Safety, DOE Order 460.1, U.S. Department of Energy, Washington, D.C.

DOE, 1995, Waste Acceptance Product Specifications for Vitrified High-Level Waste Forms, EM-WAPS, Rev. 1, U.S. Department of Energy, Office of Environmental Management, Washington, D.C.

DOE-RW, 1994, Waste Acceptance System Requirements Document (WASRD), D0E/RW-0351P, Rev. 1, Section 3, U.S. Department of Energy, Washington, D.C.

National Environmental Policy Act of 1969, 42 USC 4321, et seq.

NRC, 1981, Guidelines for Control Room Design Reviews, NUREG-0700, U.S. Nuclear Regulatory Commission, Washington, D.C.

Resource Conservation and Recovery Act of 1976, 42 USC 6901, et seq.

$\mathrm{RL}, 1996$, TWRS Privatization Request for Proposals, Solicitation

Number DE-RP06-96RL13308, U.S. Department of Energy, Rich1and Operations office, Richland, Washington.

Superfund Amendments and Reauthorization Act of 1986, 42 USC 6921, et seq. 
WAC 173-303, "Dangerous Waste Regulations," Washington Administrative Code, as amended.

WAC 173-460, "Controls for New Sources of Toxic Air Pollutants, "Washington Administrative Code, as amended.

WAC 173-480, "Ambient Air Quality Standards and Emission Limits for Radionuclides," Washington Administrative Code, as amended.

WAC 246-220, "Radiation Protection - General Provisions," Washington Administrative Code, as amended.

WAC 246-247, "Radiation Protection - Air Emissions," Washington Administrative Code, as amended.

Washington Clean Air Act of 1967, Revised Code of Washington, Chapter 70.94, 01 ympia, Washington.

WHC-CM-4-11, ALARA Program Manual, Westinghouse Hanford Company, Richland, Washington.

WHC-CM-7-5, Environmental Compliance, Westinghouse Hanford Company, Richland, Washington.

WHC, 1994, Hanford Site Radiological Control Manual, HSRCM-1, Rev. 2, Westinghouse Hanford Company, Richland, Washington.

WHC, 1996, Tank Waste Remediation System Functions and Requirements, WHC-SD-WM-FRD-020, Rev. 0, West inghouse Hanford Company, Richland, Washington.

WIPP, 1991, TRU Waste Acceptance Criteria for the Waste Isolation Pi7ot Plant, DOE/WIPP-069, Rev. 4, Westinghouse Electric Corporation, Carlsbad, New Mexico. 
WHC-SD-WM-FRD-027 Rev. 0

This page intentionally left blank. 


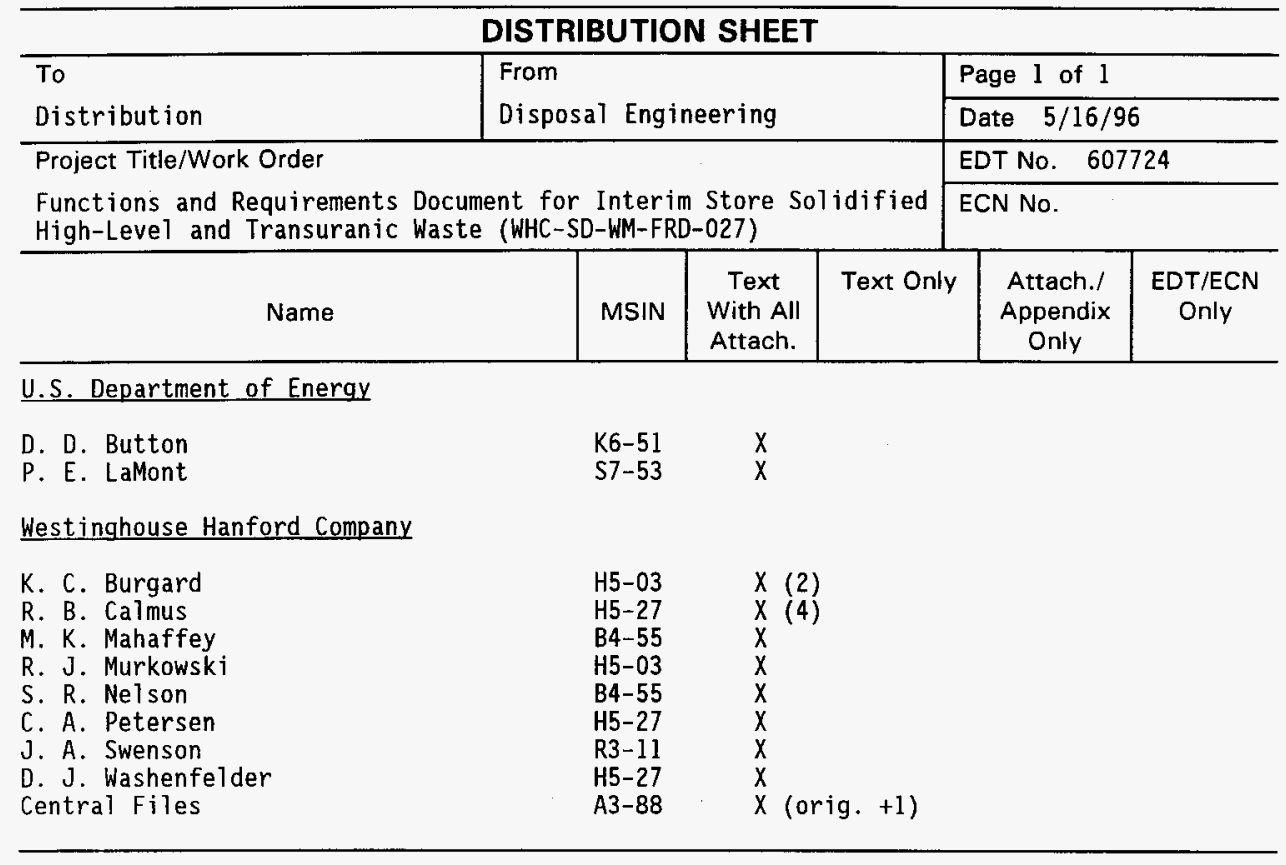

